\title{
Evaluating the potential to extract high-resolution paleoclimate information from the near-shore New Zealand molluscan species Austrovenus stutchburyi
}

\author{
Jessica J. Orsman
}

A thesis submitted for the partial fulfilment for the degree of Master of Science with

Honours in Geology, Victoria University of Wellington, March 2011 
$\begin{array}{ll}\text { Abstract } & 4\end{array}$

$\begin{array}{lr}\text { List of Figures } & 6\end{array}$

$\begin{array}{lr}\text { List of Tables } & 8\end{array}$

$\begin{array}{lr}\text { Acknowledgments } & 9\end{array}$

1.0 THE POTENTIAL OF MOLLUSCS AS PALEOENVIRONMENTAL 10 PROXIES

$\begin{array}{lr}\text { 1.1 General introduction and thesis objectives } & 10\end{array}$

1.2 Extracting paleoenvironmental information from molluses 11

$\begin{array}{lr}1.3 \text { Biomineralization } & 14\end{array}$

1.4 Trace Element Incorporation $\quad \mathbf{1 6}$

1.4.1 $\mathrm{Mg} / \mathrm{Ca}$ and $\mathrm{Sr} / \mathrm{Ca}$ in molluscs: proxies for sea surface temperature? $\mathbf{1 7}$

1.4.2 $\mathrm{Ba} / \mathrm{Ca}$ and $\mathrm{Mn} / \mathrm{Ca}$ : Indicators of primary productivity, salinity and $\mathbf{2 3}$ redox?

1.4.3 As/Ca, Zn/Ca, Cu/Ca and Pb/Ca as pollutant tracers $\mathbf{2 5}$

1.5 Sclerochronology: Bivalve microstructure and growth information 26

1.5.1 Shell microstructure $\quad \mathbf{2 6}$

$\begin{array}{ll}\text { 1.5.2 A. stutchburyi microstructure } & \mathbf{2 7}\end{array}$

1.5.3 Growth increments $\quad \mathbf{2 8}$

1.5.4 A. stutchburyi growth increments $\quad \mathbf{2 9}$

1.5.5 Factors affecting bivalve growth and A. stutchburyi growth 30

1.6 Thesis structure $\quad 32$

2.0 MATERIALS AND METHODS 33

2.1 Study species: A. stutchburyi

2.2 Sampling locations $\quad 34$

$\begin{array}{ll}\text { 2.3 Sample collection } & 37\end{array}$

$\begin{array}{ll}\text { 2.4 Sample preparation } & \mathbf{3 7}\end{array}$

2.4.1 A. stutchburyi shells $\quad 37$

2.4.2 Sediment $\quad \mathbf{3 8}$

2.5 Sample analysis $\quad 39$

2.5.1 A. stutchburyi shells - LA-ICP-MS trace element analysis 39

2.5.2 Sediment-X-rayfluorescence $\quad \mathbf{4 1}$

2.6 Analytical uncertainty in LA-ICP-MS analysis 41

3.0 RESULTS $\quad 44$

3.1 A. stutchburyi trace element chemistry $\quad 44$

3.1.1 Transects through the shell $\quad 44$ 
3.1.2.1 Key trends and differences between the Ligar Bay and

Ligar Estuary shells

3.1.2.2 Individual Ligar Bay transects

59

3.1.2.3 Trace element/Ca ratio transects for A. stutchburyi at other

68

New Zealand sites

3.1.3 Inner versus outer shell average trace element/Ca ratios

73

3.14 Correlations between trace elements

75

3.1.5 Shell averages of trace element/Ca ratios

78

3.2 Sediment major elements -Mg/Ca, Mn/Ca and Al/Ca

4.0 DISCUSSION

$\begin{array}{ll}\text { 4.1 A. stutchburyi scelerochronology } & \mathbf{8 4}\end{array}$

4.1.1 Extracting a high-resolution chronology; the limitations of $\quad \mathbf{8 4}$ scelerochronology

4.1.2 Identifying annual growth bands $\quad \mathbf{8 9}$

4.1.3 Constructing an annual chronology for Ligar Bay $3 B$ and $4 B$ shells 91

4.2 Factors affecting trace element incorporation in A. stutchburyi 93

4.2.1 A. stutchburyi growth rate $\quad \mathbf{9 3}$

4.2.2 Growth rate and age correlation with trace element/Ca ratios $\quad 94$

4.2.3 $\mathrm{Sr} / \mathrm{Ca}$ and $\mathrm{Mg} / \mathrm{Ca}$ ratios $\quad \mathbf{9 8}$

$\begin{array}{lr}\text { 4.2.4 Ba/Ca ratios } & \mathbf{1 0 7}\end{array}$

4.2.5 Mn/Ca and U/Ca ratios $\quad 113$

4.2.6 As/Ca, Zn/Ca and $\mathrm{Cu} / \mathrm{Ca}$ ratios $\quad \mathbf{1 1 8}$

4.3 Summary and comparison to other molluscan studies 120

$\begin{array}{lr}\text { 4.3.1 Growth rate and ontogenetic trends } & \mathbf{1 2 1}\end{array}$

4.4 Evaluation of A. stutchburyi as an archive for past environmental 125 change

$\begin{array}{lr}\text { 5.0 CONCLUSIONS } & 127\end{array}$

$\begin{array}{lr}5.1 \text { Suggestions for further work } & 128\end{array}$

$\begin{array}{lr}\text { 6.0 REFERENCES } & 130\end{array}$

7.0 APPENDICES CD

Analytical data for each shell: Ligar Bay 1B, Ligar Bay 3B, Ligar Bay 4B, Ligar Bay 6B, Ligar Estuary, Kawhia, Raglan, Miranda, Kaiaua, Manakau and Pomare. 


\section{ABSTRACT}

$\mathrm{Li}, \mathrm{B}, \mathrm{Mg}, \mathrm{Al}, \mathrm{Mn}, \mathrm{Cu}, \mathrm{Zn}, \mathrm{As}, \mathrm{Sr}, \mathrm{Ba}$ and $\mathrm{U} / \mathrm{Ca}$ ratios were measured by laser ablation inductively coupled plasma mass spectrometry for 11 modern Austrovenus stutchburyi clams to assess the potential of this molluscan species as a proxy for paleo-ocean temperature and environmental change. A. stutchburyi is an intertidal, infaunal, bivalve, widespread in New Zealand coastal regions and throughout the Quaternary-Pliocene sedimentary rock record. Five individuals from Ligar Bay and Estuary (South Island, New Zealand) were analysed to evaluate the variability between individuals calcifying in similar environmental conditions. A further six individuals were sampled from a range of latitudes $\left(38^{\circ}\right.$ to $\left.40^{\circ}\right)$ in the North Island, New Zealand to evaluate variability between individuals from different environments.

A strong positive correlation between growth rate and $\mathrm{Mg}, \mathrm{Al}, \mathrm{Mn}, \mathrm{Sr}, \mathrm{Ba}$ and $\mathrm{U} / \mathrm{Ca}$ ratios was observed, and a marked negative correlation was found between the same trace element/Ca ratios and ontogenetic age as growth rates slow during the molluscs' life. Thus, biological effects are the primary influence on trace element incorporation in A. stutchburyi. No clear seasonal variations were observed in the $\mathrm{Mg}$ and $\mathrm{Sr} / \mathrm{Ca}$ ratio profiles through A. stutchburyi shells representing time periods of several years. Furthermore, for two shells for which chronologies could be reliably constructed, there were no significant correlations between $\mathrm{Mg}$ and $\mathrm{Sr} / \mathrm{Ca}$ ratios and sea surface temperature. When $\mathrm{Mg} / \mathrm{Ca}$ ratios were normalised to $\mathrm{Sr} / \mathrm{Ca}$ ratios in order to eliminate the growth rate effect on trace element incorporation into the mollusc shells, some of the remaining variations appeared to visually correlate positively with sea surface temperature in several sections of a shell. However, a quantitative correlation did not confirm this $\left(\mathrm{r}^{2}=0.012\right)$. It is likely that neither $\mathrm{Mg}$ nor $\mathrm{Sr}$ incorporation into $A$. stutchburyi shell are primarily thermodynamically controlled. 
Several coincident $\mathrm{Ba} / \mathrm{Ca}$ peaks in two of the Ligar Bay shells are most likely caused by environmental processes such as short periods of phytoplankton blooms or elevated seawater $\mathrm{Ba} / \mathrm{Ca}$ from river flooding. $\mathrm{Mn} / \mathrm{Ca}$ and $\mathrm{U} / \mathrm{Ca}$ variations in A. stutchburyi from different coastal sites with different sediment characteristics appeared to be linked to the redox conditions prevailing at an open ocean sand-dominated environment (Ligar Bay) versus tidal mud flat environments (e.g. Miranda). Thus, while A. stutchburyi is unlikely to be a useful archive for past coastal ocean temperatures, it holds considerable promise for tracking past changes in coastal ocean productivity and river run-off, as well as sediment redox conditions. 
$\begin{array}{lll}\text { Figure 1.1 Schematic bivalve radial section } & \mathbf{1 4}\end{array}$

Figure 1.2 Ion exchange in the molluscan mineralizing system $\mathbf{1 6}$

$\begin{array}{lll}\text { Figure 1.3 Cations in the calcite crystalline structure } & \mathbf{1 7}\end{array}$

$\begin{array}{lll}\text { Figure 1.4 Cations in the aragonite crystalline structure } & \mathbf{1 7}\end{array}$

$\begin{array}{lll}\text { Figure 1.5 Schematic cross-section of } A \text {. stutchburyi } & \mathbf{2 7}\end{array}$

Figure 1.6 Photograph of A. stutchburyi spring and neap tide micro- 30

$\begin{array}{lll}\text { Figure 1.7 Growth rate and age model for A. stutchburyi. } & 31\end{array}$

Figure 2.1 Photograph showing one valve of A. stutchburyi 34

Figure 2.2 Map of sample locations $\quad 35$

Figure 2.3 A. stutchburyi shell showing maximum growth direction 38

Figure 2.4 A. stutchburyi mounted in epoxy 38

Figure 2.5 Cross section of Ligar Bay 1B showing LA-ICP-MS path 39

Figure 2.6 TE/Ca ratios for the Kaiaua original and repeat transects 43

Figure 3.1 Two types of transects made in A. stutchburyi shells 44

Figure 3.2 $\mathrm{Mg} / \mathrm{Ca}, \mathrm{Mn} / \mathrm{Ca}, \mathrm{Sr} / \mathrm{Ca}, \mathrm{U} / \mathrm{Ca}, \mathrm{Ba} / \mathrm{Ca} \mathrm{Al} / \mathrm{Ca}, \mathrm{Cu} / \mathrm{Ca}$ and $\mathrm{Li} / \mathrm{Ca}$

Figure 3.3 $\mathrm{B} / \mathrm{Ca}, \mathrm{As} / \mathrm{Ca}$ and $\mathrm{Zn} / \mathrm{Ca}$ cross-section transects 46

Figure 3.4 $\mathrm{Mg} / \mathrm{Ca}$ ratios in the Ligar Bay and Ligar Estuary shells $\quad \mathbf{5 1}$

Figure 3.5 $\mathrm{Sr} / \mathrm{Ca}$ ratios in the Ligar Bay and Ligar Estuary shells $\quad \mathbf{5 1}$

Figure 3.6 $\mathrm{Mn} / \mathrm{Ca}$ ratios in the Ligar Bay and Ligar Estuary shells $\mathbf{5 2}$

Figure 3.7 $\mathrm{Ba} / \mathrm{Ca}$ ratios in the Ligar Bay and Ligar Estuary shells $\mathbf{5 2}$

Figure 3.8 U/Ca ratios in the Ligar Bay and Ligar Estuary shells $\quad \mathbf{5 3}$

Figure 3.9 $\mathrm{Cu} / \mathrm{Ca}$ ratios in the Ligar Bay and Ligar Estuary shells $\quad \mathbf{5 3}$

Figure 3.10 $\mathrm{Zn} / \mathrm{Ca}$ ratios in the Ligar Bay and Ligar Estuary shells $\mathbf{5 6}$

Figure 3.11 As/Ca ratios in the Ligar Bay and Ligar Estuary shells $\quad \mathbf{5 6}$

$\begin{array}{lll}\text { Figure 3.12 } & \mathrm{Li} / \mathrm{Ca} \text { ratios in the Ligar Bay and Ligar Estuary shells } & \mathbf{5 7}\end{array}$

Figure 3.13 B/Ca ratios in the Ligar Bay and Ligar Estuary shells $\quad \mathbf{5 7}$

Figure 3.14 $\mathrm{Al} / \mathrm{Ca}$ ratios in the Ligar Bay and Ligar Estuary shells $\quad \mathbf{5 8}$

Figure 3.15 Ligar Bay $1 \mathrm{~B} \mathrm{Mg} / \mathrm{Ca}, \mathrm{Sr} / \mathrm{Ca}, \mathrm{Mn} / \mathrm{Ca}, \mathrm{Ba} / \mathrm{Ca}$ and $\mathrm{Zn} / \mathrm{Ca}$ ratios

Figure 3.16 Ligar Bay 3B Mg/Ca, $\mathrm{Sr} / \mathrm{Ca}, \mathrm{Mn} / \mathrm{Ca}, \mathrm{Ba} / \mathrm{Ca}$ and $\mathrm{U} / \mathrm{Ca}$ ratios 62

Figure 3.17 Ligar Bay 4B Mg/Ca, $\mathrm{Sr} / \mathrm{Ca}, \mathrm{Mn} / \mathrm{Ca}, \mathrm{Ba} / \mathrm{Ca}$ and $\mathrm{U} / \mathrm{Ca}$ ratios 64

Figure 3.18 Ligar Bay $6 \mathrm{~B} \mathrm{Mg} / \mathrm{Ca}, \mathrm{Sr} / \mathrm{Ca}, \mathrm{Mn} / \mathrm{Ca}, \mathrm{Ba} / \mathrm{Ca}$ and $\mathrm{U} / \mathrm{Ca}$ ratios 65

Figure 3.19 Ligar Estuary $\mathrm{Mg} / \mathrm{Ca}, \mathrm{Sr} / \mathrm{Ca}, \mathrm{Mn} / \mathrm{Ca}, \mathrm{Ba} / \mathrm{Ca}$ and $\mathrm{U} / \mathrm{Ca}$ ratios 67

Figure 3.20 Kawhia $\mathrm{Mg} / \mathrm{Ca}, \mathrm{Sr} / \mathrm{Ca}, \mathrm{Mn} / \mathrm{Ca}, \mathrm{Ba} / \mathrm{Ca}$ and $\mathrm{U} / \mathrm{Ca}$ ratios 69

Figure 3.21 Raglan $\mathrm{Mg} / \mathrm{Ca}, \mathrm{Sr} / \mathrm{Ca}, \mathrm{Mn} / \mathrm{Ca}, \mathrm{Ba} / \mathrm{Ca}$ and $\mathrm{U} / \mathrm{Ca}$ ratios 69

Figure 3.22 Miranda $\mathrm{Mg} / \mathrm{Ca}, \mathrm{Sr} / \mathrm{Ca}, \mathrm{Mn} / \mathrm{Ca}, \mathrm{Ba} / \mathrm{Ca}$ and $\mathrm{U} / \mathrm{Ca}$ ratios 71

Figure 3.23 Kaiaua $\mathrm{Mg} / \mathrm{Ca}, \mathrm{Sr} / \mathrm{Ca}, \mathrm{Mn} / \mathrm{Ca}, \mathrm{Ba} / \mathrm{Ca}$ and $\mathrm{U} / \mathrm{Ca}$ ratios 71

Figure 3.24 Pomare $\mathrm{Mg} / \mathrm{Ca}, \mathrm{Sr} / \mathrm{Ca}, \mathrm{Mn} / \mathrm{Ca}, \mathrm{Ba} / \mathrm{Ca}$ and $\mathrm{U} / \mathrm{Ca}$ ratios 72

Figure 3.25 Manakau $\mathrm{Mg} / \mathrm{Ca}, \mathrm{Sr} / \mathrm{Ca}, \mathrm{Mn} / \mathrm{Ca}, \mathrm{Ba} / \mathrm{Ca}$ and $\mathrm{U} / \mathrm{Ca}$ ratios 72

Figure 3.26 Comparison of average $\mathrm{Mg} / \mathrm{Ca}$ ratios in the inner and outer shell $\mathbf{7 4}$

Figure 3.27 Comparison of average $\mathrm{Ba} / \mathrm{Ca}$ ratios in the inner and outer shell $\mathbf{7 4}$

Figure 3.28 Correlation between $\mathrm{Mg} / \mathrm{Ca}$ and $\mathrm{Ba} / \mathrm{Ca}$ ratios from Kawhia $\mathbf{7 6}$ 
Figure 3.30 Shell averages for $\mathrm{Mg} / \mathrm{Ca}, \mathrm{A} / \mathrm{Ca}, \mathrm{Mn} / \mathrm{Ca}, \mathrm{Cu} / \mathrm{Ca}, \mathrm{Zn} / \mathrm{Ca}, \mathrm{As} / \mathrm{Ca}$, $\mathrm{Sr} / \mathrm{ca}$ and $\mathrm{Ba} / \mathrm{Ca}$.

Figure 3.31 Shell averages for $\mathrm{U} / \mathrm{Ca}, \mathrm{B} / \mathrm{Ca}$ and $\mathrm{Li} / \mathrm{Ca}$

Figure 4.1 Growth patterns on Ligar Bay 1B at 108x magnification

Figure 4.2 Growth patterns on Ligar Bay $1 \mathrm{~B}$ at 200x magnification

85

Figure 4.3 Photograph of the Ligar Estuary shell after treatment in Mutvei's

85 solution

Figure 4.4 V-shaped notch associated with a growth band in Ligar 6B

Figure 4.5 A growth band without a notch in Ligar Bay 1B.

90

Figure 4.6 Schematic diagram showing the relationship interpreted between

90 annual growth bands on the Ligar Bay 3B and Ligar Bay 4B shells.

Figure 4.7 Shell growth direction (shell extension) and the crystal growth direction

Figure 4.8 Correlations between growth rate (mm/year) for growth increments in Ligar Bay shells and average TE/Ca ratios

Figure 4.9 Growth rate and ontogenetic age correlations with $\mathrm{Mg} / \mathrm{Ca}$, $\mathrm{Sr} / \mathrm{Ca}, \mathrm{M} / \mathrm{Ca}, \mathrm{Ba} / \mathrm{Ca}$ and $\mathrm{U} / \mathrm{Ca}$ for individual Ligar Bay shells

Figure 4.10 $\mathrm{Mg} / \mathrm{Ca}(\mathrm{mmol} / \mathrm{mol})$ and $\mathrm{Sr} / \mathrm{Ca}(\mathrm{mmol} / \mathrm{mol})$ records from Ligar Bay 4B plotted against time

Figure 4.11 $\mathrm{Mg} / \mathrm{Ca}(\mathrm{mmol} / \mathrm{mol})$ and $\mathrm{Sr} / \mathrm{Ca}(\mathrm{mmol} / \mathrm{mol})$ records from Ligar Bay 3B plotted against time

Figure 4.12 Age detrended $\mathrm{Sr} / \mathrm{Ca}$ record for Ligar Bay 3B

Figure 4.13 $\mathrm{Mg} / \mathrm{Ca}$ ratios normalised to $\mathrm{Sr} / \mathrm{Ca}$ from Ligar Bay 3B

Figure 4.14 $\mathrm{Mg} / \mathrm{Ca}$ ratios normalised to $\mathrm{Sr} / \mathrm{Ca}$ from Ligar Bay 4B

Figure 4.15 Normalised $\mathrm{Mg} / \mathrm{Ca}$ from increment four in Ligar Bay 4B

Figure 4.16 Correlation between growth rate $(\mathrm{mm} / \mathrm{month})$ and sea surface temperature for A. stutchburyi

101

102

103

104

104

105

Figure 4.17 $\mathrm{Ba} / \mathrm{Ca}$ ratios from Ligar Bay $3 \mathrm{~B}$ compared to $\mathrm{Ba} / \mathrm{Ca}$ ratios from Ligar Bay 3B after being normalised to $\mathrm{Sr} / \mathrm{Ca}$

Figure 4.18 Maps of seasonal chlorophyll (phytoplankton abundance) across Golden Bay

Figure 4.19 Average chlorophyll concentrations in each season of 2001-2002 at Golden Bay

Figure 4.20 $\mathrm{Ba} / \mathrm{Ca}$ ratios from Ligar Bay $3 \mathrm{~B}$ and Ligar Bay 4B compared to total monthly rainfall

Figure 4.21 Synchronous $\mathrm{Ba} / \mathrm{Ca}$ ratio peaks in three $P$. maximus shells

Figure 4.22 Average $\mathrm{Mn} / \mathrm{Ca}$ ratios in each A. stutchburyi shell

Figure 4.23 Average U/Ca ratios in each A. stutchburyi shell

Figure 4.24 $\mathrm{Mn} / \mathrm{Ca}$ records from Pomare and Ligar Estuary, showing spikes in $\mathrm{Mn} / \mathrm{Ca}$.

Figure 4.25 $\mathrm{Mn} / \mathrm{Ca}$ profiles in the calcite shell layer of a M. edulis compared to measured chlorophyll $a$ concentrations

Figure 4.26 As/Ca records from all shells plotted against distance from the ventral margin. 
Table 1.1

Table 1.2

Table 2.1

Table 2.2

Table 2.3

Table 3.1

Table 3.2

Table 3.3

Table 3.4

Table 4.1

Table 4.2

Table 4.3

Table 4.4
Summary of key studies of $\mathrm{Mg}$ incorporation in 21 molluscan shells Summary of key studies of Sr incorporation in molluscan shells

Summary of field locations $\quad 36$

LA-ICP-MS operating parameters $\quad 40$

Analytical uncertainty

Summary of the range in TE/Ca ratios for the Ligar Bay $\mathbf{5 8}$ and Ligar Estuary shells

Correlations between $\mathrm{Mg} / \mathrm{Ca}, \mathrm{Sr} / \mathrm{Ca}, \mathrm{Mn} / \mathrm{Ca}, \mathrm{Ba} / \mathrm{Ca}$ and

$\mathrm{U} / \mathrm{Ca}$ across the entire dataset

$\mathrm{X}$-ray fluorescence major oxide analysis of sediment collected at each site

$\mathrm{Mg} / \mathrm{Ca}, \mathrm{Al} / \mathrm{Ca}$ and $\mathrm{Mn} / \mathrm{Ca}$ ratios for sediment samples compared with average $\mathrm{Mg} / \mathrm{Ca}, \mathrm{Al} / \mathrm{Ca}$ and $\mathrm{Mn} / \mathrm{Ca}$ ratios for each shell

Average shell growth rate $(\mathrm{mm} / \mathrm{yr})$ compared with average trace element/Ca ratios

Results from student-t test between Ligar Estuary and each Ligar Bay shell 


\section{ACKNOWLEDGEMENTS}

Thank you to my supervisors for their time and support, Joel Baker and David Kennedy. Joel, thank you for sharing your brilliant scientific expertise, and encouraging me to do the project in the first place. I have been really grateful for your quick turn-around on my drafts over the last two months, it enabled me to finish this thesis in time for Law School. Dave, throughout the project your enthusiasm, prompt feedback and advice (even from across the Tasman) was greatly appreciated - thanks! Thank you also to Gavin Dunbar and Lionel Carter for additional advice and input in the project.

Thank you to those who provided technical support, particularly Monica Handler and Marc-Alban Millet in the geochemistry lab, and Stewart Bush for helping with sample preparation. Thank you to Gigi for help on the fieldwork - I suspect we wouldn't have remembered to collect any sediment without you there!

I have been lucky to have wonderful officemates throughout postgrad - Netty, Julene, John, Kylie, George C., Aidan, Katy and Simon. Thanks for the many, many chats, encouragement, and more recently for putting up with me in the final writing stages, including borderline OCD door shutting.

Thank you to all my friends, both in geology and the real world, including: Morgan, Surrey, Andy, George D, Sophie, Chelsea, Alexa, Nicole, Chris M, Matt and Anne. Special thanks to Ramona White for the data-processing problem-solving and for baking me the most awesome chocolate slice, and to Louise Clark for listening to the painstaking details of this project as it unfolded, and nevertheless always being a positive influence. Also to Sarah Martin, for being a great friend to share the Masters experience with! Thank you for the innumerable coffees, lunch breaks, productive and unproductive chats, and being a source of always rational advice.

Finally, to my family: Penny, Roger, Chris D, Grandma, Granddad, Nana, Alice, Bonnie, Min and Pierro - thank you for your support! Dad, thank you for supporting me at University - I'm really lucky to have that. Rose, thanks for being the better sister - I will always admire your optimistic outlook on life and feel blessed to have you in mine. Mum, I can't possibly thank you enough. You don't even like science but you've listened for endless hours to me talk about the ins and outs, and ups and downs of this thesis, and genuinely cared. 


\section{CHAPTER 1.0}

THE POTENTIAL OF MOLLUSCS AS PALEOENVIRONMENTAL PROXIES

\subsection{General introduction and thesis objectives}

Geochemical records extracted from marine biogenic carbonates, particularly foraminifera and corals, have provided a wealth of paleoceanographic and paleoclimatic information (Katz et al., 2010), including ocean temperature (Elderfield and Ganssen, 2000; Lear et al., 2000; Sadekov et al., 2009), salinity (Schmidt et al., 2004; Arbuszewski et al., 2010) and ice volume, primary production and tracing terrigenous influx of elements (McCulloch et al,, 2003; Sinclair and McCulloch, 2004; Klinkhammer et al., 2009). Molluscan species also offer the possibility of highresolution, sub-seasonal records of paleo-ocean conditions in coastal environments, especially when coupled with the interpretation of shell growth patterns (sclerochronology) (Richardson, 2001).

$\mathrm{Mg} / \mathrm{Ca}$ and $\mathrm{Sr} / \mathrm{Ca}$ ratios in molluscan shells have been correlated to temperature in some cases (Dodd, 1965; Klein et al., 1996; Vander Putten et al., 2000; Elliot et al., 2009), but in most other cases the geochemistry has been linked to physiological factors such as calcification (growth) or metabolic rate (Klein et al., 1996; Lorrain et al., 2005; Gillikin et al., 2005; Carré et al., 2006; Takesue et al., 2008). Nevertheless, more molluscan species need to be analysed to test their potential as paleoenvironmental proxies. Further, the incorporation of other trace elements may provide other important environmental information. In particular, $\mathrm{Ba} / \mathrm{Ca}$ and $\mathrm{Mn} / \mathrm{Ca}$ ratios in molluscs have been linked to seawater concentrations, phytoplankton blooms, and sediment run-off (Vander Putten et al., 2000; Lazareth, 2003; Freitas et al., 2006; Gillikin et al., 2006; Gillikin et al., 2008); and the incorporation of heavy metals ( $\mathrm{Pb}, \mathrm{Zn}, \mathrm{Cu} \mathrm{As}$ ) have been 
used to study levels of contaminants (Purchase and Fergusson 1985; Richardson, 2001). Thus, trace elements in molluscan shells have the potential to be useful tracers of ocean and estuarine chemistry or conditions, as well as biomarkers for pollution (Freitas et al., 2006).

The key objectives of this thesis were to investigate the mechanisms controlling trace element incorporation into the shell of the New Zealand clam Austrovenus stutchburyi and identify potential paleo-temperature or environmental indicators. A. stutchburyi was chosen because of its abundance in New Zealand at a range of latitudes and preservation in the fossil record. Trace element ratios $(\mathrm{Li} / \mathrm{Ca}, \mathrm{B} / \mathrm{Ca}, \mathrm{Mg} / \mathrm{Ca}, \mathrm{Al} / \mathrm{Ca}, \mathrm{Mn} / \mathrm{Ca}, \mathrm{Cu} / \mathrm{Ca}$, $\mathrm{Zn} / \mathrm{Ca}, \mathrm{As} / \mathrm{Ca}, \mathrm{Sr} / \mathrm{Ca}, \mathrm{Ba} / \mathrm{Ca}$ and $\mathrm{U} / \mathrm{Ca}$ ) were determined using laser ablationinductively coupled plasma-mass spectrometry (LA-ICP-MS) in modern specimens of $A$. stutchburyi. Eleven shells from eight locations were analysed to evaluate the variability of shell element chemistry between individuals, including individuals from the same site and environmental conditions (Vander Putten et al., 2000). Sediment samples from each collection location were also analysed by X-ray fluorescence to compare shell major element/Ca ratios to those which occur in the clams' habitat.

\subsection{Extracting paleoenvironmental information from molluscs}

Arguably one of the most important developments in the paleoclimate field, and for geology, in the $20^{\text {th }}$ century was the discovery of a thermodynamic fractionation of oxygen isotopes $\left({ }^{18} \mathrm{O}\right.$ and $\left.{ }^{16} \mathrm{O}\right)$ in the calcium carbonate shell of marine organisms, which are precipitated at near isotopic equilibrium with seawater (Urey, 1947; Epstein, 1953). This relationship has enabled numerous records of paleoceanographic and paleoclimatic conditions to be made from the $\delta^{18} \mathrm{O}$ values of foraminiferal microfossils (Emiliani, 1955; Erez and Honjo, 1981; Deuser and Ross, 1989; Mortyn and Charles, 2003); but with one significant complication: shell $\delta^{18} \mathrm{O}$ values are a product of the 
seawater $\delta^{18} \mathrm{O}$ composition, which is influenced by salinity and continental ice volume, as well as seawater temperature (Lea et al., 2003). Over the past 10-20 years, trace element analyses in foraminifera have been at the forefront of solving "Urey's problem". In particular, species-specific calibration of the thermodynamic incorporation of $\mathrm{Mg}^{2+}$ into calcite shell have provided records of ocean temperature, isolated from the ice volume effect (Lea et al., 2000; Lear et al., 2000; Cleroux et al., 2008).

Yet while $\mathrm{Mg} / \mathrm{Ca}$ foraminifera analyses provide excellent paleo-temperature records extending as far back as the early Cenozoic (e.g. Hollis et al., 2009), the temporal resolution of paleo-ocean temperatures that foraminifera can provide is restricted to the time-span of the microfossil's life and, more critically, also the temporal resolution of the sedimentary rock record. Thermodynamically controlled trace element incorporation in corals $(\mathrm{Sr} / \mathrm{Ca}$ and $\mathrm{U} / \mathrm{Ca})$, offers sub-seasonal resolution (Cohen and McConnaughey, 2003), but the geographic location of coralline records is limited to the tropical regions. In addition, the aragonite skeletons of coral appear to be sensitive to diagenetic and vital effects, which means their records tend not to be well preserved in the paleo-record (Lea et al., 2003).

However, molluscs potentially have several advantages for reconstructing paleoclimate. They are geographically widespread, occurring in all types of shallow marine environments. The sequential manner in which shells are precipitated, with discrete increments of growth marked by growth patterns, potentially allows a high-resolution (seasonal to sub-tidal) record of the environment to be reconstructed over the life span of the mollusc (years to centuries) (Richardson, 2001; Freitas et al., 2006). Oxygen isotope analyses that have been conducted on a number of molluscan species have proved the success of integrating geochemistry and sclerochronology (Schöne et al., 2004; Schöne et al., 2007; Schöne, 2009; Klein et al., 1996; Goodwin, 2003); however, 
the same difficulty of deconvolving the ambient temperature signal from the seawater $\delta^{18} \mathrm{O}$ signal is encountered.

Developing trace element-temperature calibrations for molluscan species would create a powerful tool for determining paleo-ocean temperatures that could resolve crucial paleoclimate questions. The requirement for seasonal climate data is commonly recognised; as emphasis is being placed on the role of seasonal changes in driving global climate change (Schöne, 2010). For example, modelling permanent ice cover in the northern and southern hemispheres is dependent on seasonal temperature data (Crowley et al., 1986). In New Zealand, a molluscan paleo-ocean temperature proxy that could provide seasonally and annually resolved past ocean temperature data would allow assessment of the effect of the El Niño Southern Oscillation (ENSO), which an important present-day control on NZ's annual climate and on NZ in past climatic regimes. Furthermore, the near-shore record of ocean and estuarine temperatures has the potential to resolve (past and future) geographically muted or magnified local responses to broad global warming or cooling events.

However, to date, very few successful calibrations utilising $\mathrm{Sr} / \mathrm{Ca}$ and $\mathrm{Mg} / \mathrm{Ca}$ shell ratios have been reported for molluscs (Dodd, 1965; Klein et al., 1996; Table 1.1-1.2). This could be due to the limited number of molluscan species that have been studied, and so arguably the potential of molluscan paleo-ocean temperature proxies is not yet fulfilled (Freitas et al., 2006). Reported results have shown it is likely that there are species-specific biological or physiological influences on trace element incorporation, in addition to the ambient environmental factors of interest (Freitas et al., 2006). These factors, such as calcification rate, appear to be a major complication in the use of trace elements in molluscs; however they may not affect all species. Therefore, carrying out investigations on species that have not yet been studied is still important, and will add to 
the limited, but growing knowledge base on the potential of molluscs as archives of paleo-ocean temperatures.

Finally, in addition to potential $\mathrm{Mg} / \mathrm{Ca}$ and $\mathrm{Sr} / \mathrm{Ca}$ paleothermometry applications, the discovery of non-thermodynamic relationships for the incorporation of other elements (e.g. $\mathrm{Ba}, \mathrm{Mn}, \mathrm{Cu}, \mathrm{Zn}, \mathrm{As}, \mathrm{Pb}$ ) could provide useful proxies for reconstructing paleoocean chemistry, including terrigenous input of elements and ocean residence times, and also of anthropogenic contamination of coastal sites (Freitas et al., 2006; Vander Putten, 2000; Lazareth; 2003; Purchase and Fergusson 1986).

\subsection{Biomineralization}

Biomineralization is the process by which molluscs precipitate their shell, which includes the mineral $\mathrm{CaCO}_{3}$. Shell formation involves both cellular and physiochemical processes (Skinner and Jahren, 2007). The periostracum on a bivalve is a thin organic layer, which covers the shell (Figure 1.1). Enclosed within the two calcareous valves is the mantle - the primary organ of all molluscs. (Wilbur and Saleuddin, 1983).

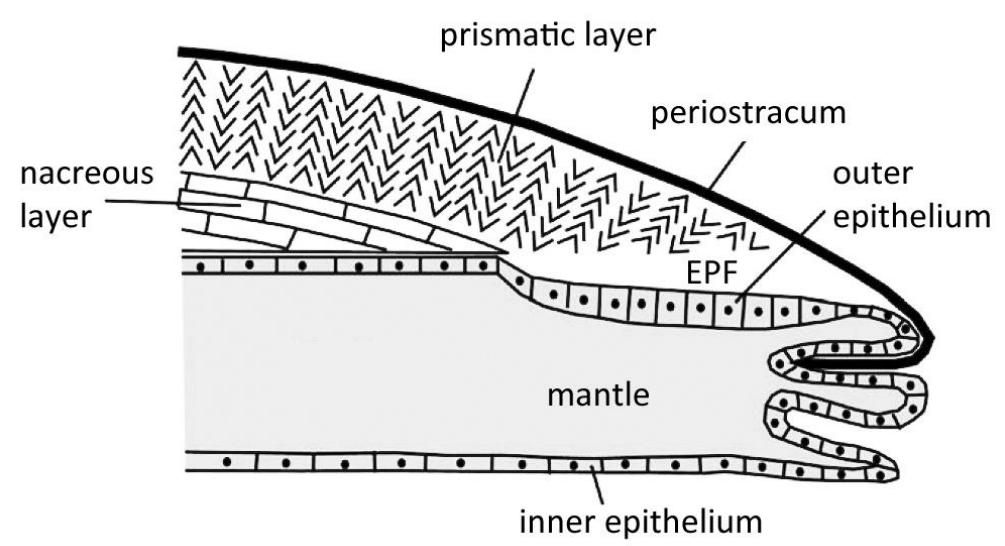

Figure 1.1 Schematic bivalve radial section showing the shell edge and mantle, and location of the extra-pallial fluid (EPF). Figure taken from Carré et al. (2006). 
Crystallisation is controlled by the mantle, and occurs within the extra-pallial space (EPS) located between the mantle epithelium and the inner shell surface. The EPS is lined with the extra-pallial fluid (EPF), which contains both the inorganic and organic sources of the shell. These include $\mathrm{Ca}^{2+}$ and $\mathrm{HCO}_{3}{ }^{-}$ions, which react to produce the mineral component of the shell $\left(\mathrm{CaCO}_{3}\right)$, and travel from the external environment to the EPS via intracellular and/or intercellular routes (Watabe and Kingsley 1989). Some $\mathrm{HCO}_{3}{ }^{-}$is also sourced from reactions within the EPF between $\mathrm{H}_{2} \mathrm{O}$ and $\mathrm{CO}_{2}-\mathrm{a}$ metabolic product. (Figure 1.2) $\mathrm{Ca}^{2+}$ and other elements that are eventually incorporated in the shell structure may enter the body tissue or hemolymph (blood) of the organism at several different locations including the gills, mantle surface and gut (Wilbur and Saleuddin, 1983; Jodrey, 1953; Horiguchi, 1958; van der Borght and Van Puymbroeck, 1966). Enzymes play a significant role in intracellular transport by enabling the elements to diffuse through the body and mantle epithelium - a process often referred to as 'metabolic pumping' (Klein et al., 1996). One such enzyme, $\mathrm{Ca}^{2+}$ ATPase, is concurrently responsible for removing $\mathrm{H}^{+}$from the EPF, which is necessary for crystallisation. Notably, ion flow is bi-directional at the cellular boundaries; therefore, when there is a shortage of $\mathrm{Ca}^{2+}$ in the external environment, the element may be lost from the EPF causing decreased calcification rate, and vice versa (Wilbur and Saleuddin, 1983). On the basis of calcification rate variation, Carré et al. (2006) have also proposed a third transport mechanism for $\mathrm{Ca}^{2+}$ via calcium channels on epithelial cell membranes. When there is a super-saturation of $\mathrm{CaCO}_{3}$ in the $\mathrm{EPF}$, and ion clusters of a critical size form, crystallisation occurs. The organic material secreted by the mantle epithelium into the EPS, primarily proteins, binds the $\mathrm{CaCO}_{3}$ crystals in an intra-crystalline matrix thereby forming the shell (Wilbur and Saleuddin, 1983). 


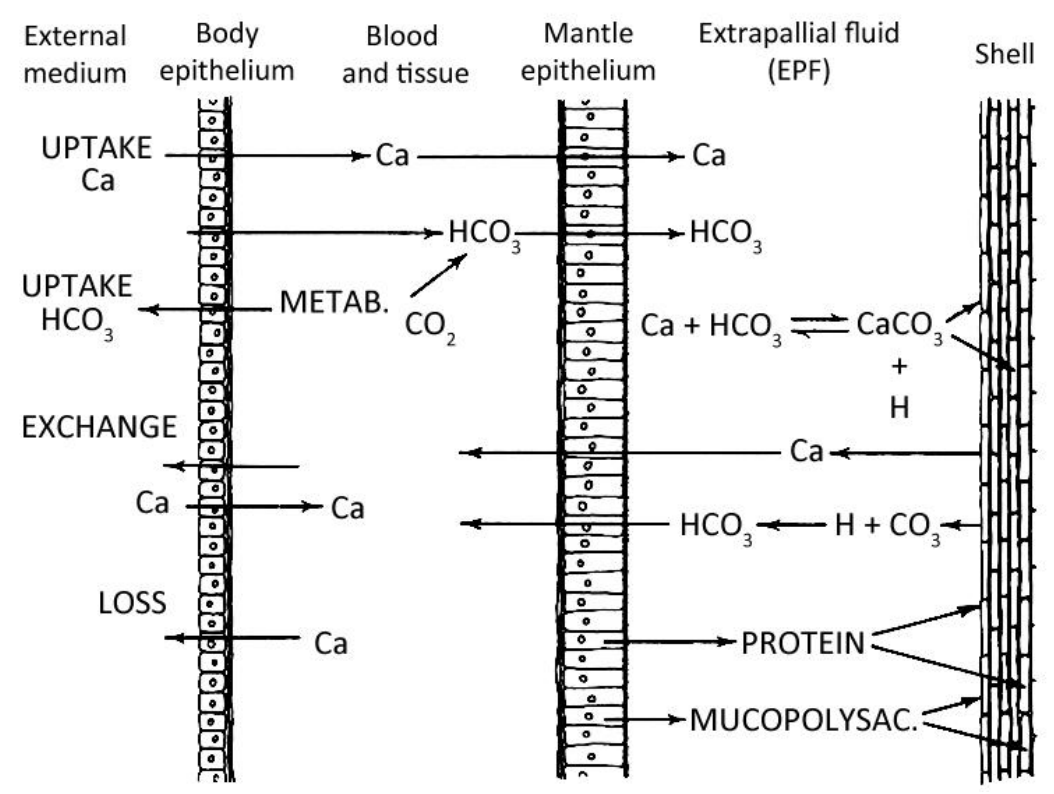

Figure 1.2 Ion exchange in the molluscan mineralizing system. Figure taken from Wilbur and Saleuddin (1983).

\subsection{Trace element incorporation}

Trace elements are incorporated into the mineral component of the shell when other cations substitute for the divalent $\mathrm{Ca}^{2+}$ cation in the $\mathrm{CaCO}_{3}$ lattice. Laboratory studies on inorganic $\mathrm{CaCO}_{3}$ show that differences in molecular structure between calcite and aragonite mean that particular cations are incorporated preferentially in the polymorphs of calcium carbonate. In calcite, where each $\mathrm{Ca}^{2+}$ ion is in 6-fold coordination with oxygen ions from $\mathrm{CO}_{3}{ }^{-}$groups, $\mathrm{Mg}^{2+}$ is dominant (Figure 1.3). On the other hand, the 9-fold coordination of $\mathrm{Ca}^{2+}$ ions in the aragonite structure allows larger cations to substitute for $\mathrm{Ca}^{2+}$ (Figure 1.4). In particular $\mathrm{Sr}$ is more readily incorporated into aragonitic $\mathrm{CaCO}_{3}$ (Skinner and Jahren 2007). Therefore, trace element concentrations in bivalves might be expected to vary depending on the polymorph present. However, it is likely that a range of internal (biological) and external factors control the incorporation of trace elements, including calcification rate, ambient temperature and metabolic processes. 


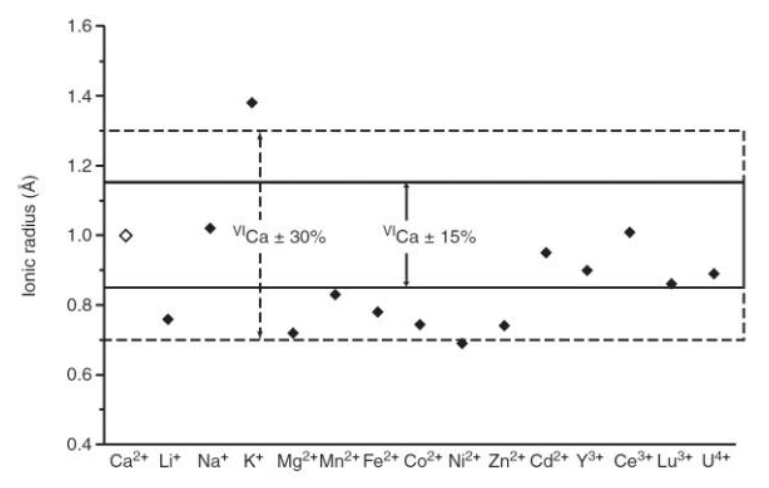

Figure 1.3 Plot of the possible "best fit" $( \pm 15 \%)$ and next best fit $(30 \%)$ of cations that could take the place of $\mathrm{Ca}$ in sixfold coordination in the calcite structure. Figure taken from Skinner and Jahren (2003).

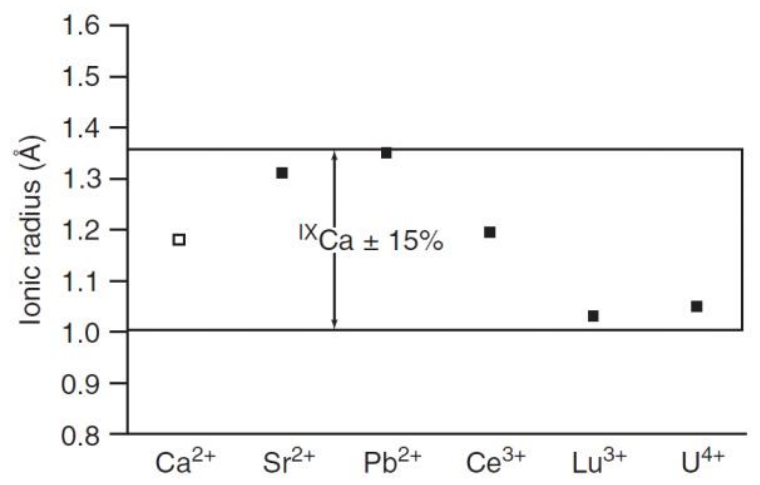

Figure 1.4 Plot of the "best fit" $( \pm 15 \%)$ of cations that could take the place of $\mathrm{Ca}$ in ninefold coordination in the aragonite structure. Figure taken from Skinner and Jahren (2003).

The following sections describe what has been discovered to date about the incorporation of certain trace elements into molluscan shells, in particular bivalves, with emphasis on the consequential use of those trace elements (TE) as proxies for (paleo-) environmental information

\subsection{1 $\mathrm{Mg} / \mathrm{Ca}$ and $\mathrm{Sr} / \mathrm{Ca}$ in molluscs: proxies for sea surface temperature?}

The residence times of $\mathrm{Ca}^{2+}, \mathrm{Mg}^{2+}$ and $\mathrm{Sr}^{2+}$ in the ocean are $1 \mathrm{Myr}, 13 \mathrm{Myr}$ and $5 \mathrm{Myr}$, respectively, compared to an ocean mixing interval of $1000 \mathrm{yr}$ (Broecker and Peng, 1982), and thus seawater $\mathrm{Mg} / \mathrm{Ca}$ and $\mathrm{Sr} / \mathrm{Ca}$ ratios are conservative over timescales shorter than those periods. Both $\mathrm{Mg} / \mathrm{Ca}$ and $\mathrm{Sr} / \mathrm{Ca}$ ratios are proposed as temperature proxies in biogenic carbonates for this reason, because they do not vary with seawater 
salinity, and because of the thermodynamic dependence of their incorporation in calcite and aragonite. Inorganic experiments on $\mathrm{Mg} / \mathrm{Ca}$ reveal a positive temperature reliance on incorporation into calcite (Mucci, 1987), and an inverse reliance on incorporation into aragonite (Gaetani and Cohen, 2004). For $\mathrm{Sr} / \mathrm{Ca}$, incorporation in aragonite is inversely related to temperature (Kinsman and Holland, 1969; Dietzel et al., 2004), while incorporation in calcite is strongly linked to precipitation rate (Lorens, 1981; Morse and Bender, 1990; Tesoriero and Pankow, 1996).

Klein et al. (1996) reported that $\mathrm{Mg} / \mathrm{Ca}$ shell ratios in the calcitic shell of the mussel Mytilus trossulus (formerly edulis) positively correlated to recorded SSTs taken periodically over a one year period $\left(r^{2}=0.74\right)$. However, earlier, Dodd $(1965)$ found only a weak, positive correlation between $\mathrm{Mg} / \mathrm{Ca}$ in calcite and temperature for Mytilus edulis and Mytilus californianus, and in fact suggested that the increase in $\mathrm{Mg} / \mathrm{Ca}$ concentration with temperature was related to shell size and thus growth rate, which increases during higher temperatures for the species (Fox and Coe, 1943; Dodd, 1964). Growth (or calcification) rate has been found to positively correlate with $\mathrm{Mg} / \mathrm{Ca}$ ratios in Mesodesma donacium and Chione subrugosa (Carré et al., 2006). When Vander Putten et al. (2000) analysed M. edulis shells they found a significant correlation between $\mathrm{Mg} / \mathrm{Ca}$ and temperature only during spring time, inferring a possible seasonal physiological effect. It was suggested this effect may be due to seasonal variations in the calcite crystal properties, which could be influenced by the surrounding organic matrix and changes to its composition, or the organic matrix may increase and decrease the absorption of trace elements from the mineral component into the matrix (Morse and Mucci, 1984, Vander Putten et al., 2000). Similarly, Takesue and van Geen (2004) reported that temperature influenced $\mathrm{Mg} / \mathrm{Ca}$ ratios to some degree in Protothaca staminea bivalves with aragonite shells. In one increment of the shell a correlation coefficient of 0.71 was observed, but this was not consistent across the other sections. 
In any case, when the calibration with the best correlation was applied to Holocene $P$. staminea fossils temperatures were considerably underestimated because of a diagenetic decrease in $\mathrm{Mg} / \mathrm{Ca}$ ratios.

Evidence of thermodynamic incorporation of $\mathrm{Sr}^{2+}$ into molluscan shell has also proved elusive. Following laboratory studies of the mussel Mytilus trossulus, Lorens and Bender (1980) found $\mathrm{Sr} / \mathrm{Ca}$ increased linearly in response to increases in $\mathrm{Sr} / \mathrm{Ca}$ in the water they lived in. Dodd (1965) reported a difference between the aragonitic and calcitic sections in M. edulis and M. californianus shells, whereby $\mathrm{Sr} / \mathrm{Ca}$ positively correlates to temperature in calcite, but shows a negative correlation in aragonite. However, subsequent studies have not revealed a temperature dependence on incorporation of Sr (Vander Putten, 2000). Rather, as for $\mathrm{Mg} / \mathrm{Ca}$, shell growth rate has been proposed as a primary cause of $\mathrm{Sr} / \mathrm{Ca}$ variations in molluscan shells. Significant correlation between growth rate and $\mathrm{Sr} / \mathrm{Ca}$ ratios has been reported for a number of species: the mussel M. edulis (Vander Putten et al., 2000); the calcitic bivalve Pecten maximus (Lorrain et al., 2005); and the aragonitic bivalves P. staminea (Takesue and van Geen, 2004), Saxidomus giganteus (Gillikin et al., 2005), M. donacium, C. subrugosa (Carré et al., 2006) and Arctica islandica (Schöne, 2011). In many cases growth rate- $\mathrm{Sr} / \mathrm{Ca}$ (and $\mathrm{Mg} / \mathrm{Ca}$ ) trends are also associated with ontogenetic trends; equating to a decrease or increase in TE/Ca ratios with the ontogenetic age of the mollusc (Takesue and van Geen 2004; Gillikin et al., 2005; Carre et al., 2006; Schöne, 2011). The trends are related, as for all molluscan species growth rate decreases as the organism grows older (Schöne, 2008).

Conversely, Klein et al. (1996) found that growth rate in M. trossulus had minimal influence on $\mathrm{Mg} / \mathrm{Ca}$ and $\mathrm{Sr} / \mathrm{Ca}$ shell concentrations, although the sample numbers used were potentially too few (only 26 data points per shell). Rather, Klein et al. (1996) 
hypothesised that $\mathrm{Sr} / \mathrm{Ca}$ ratios vary with the mollusc's metabolic efficiency in diffusing $\mathrm{Ca}^{2+}$ ions through the mantle epithelium to the EPF (Purton et al., 1999). Accordingly, low $\mathrm{Sr} / \mathrm{Ca}$ ratios observed in $M$. Trossulus calcite occurred when $\mathrm{Ca}^{2+}$ ions were pumped into the EPF at a higher rate, as a result of intra-cellular (metabolic) transport of ions (favouring $\mathrm{Ca}^{2+}$ ) exceeding inter-cellular transport of ions (non-preferential) (Wheeler, 1992). This is seen as a decrease in $\mathrm{Sr} / \mathrm{Ca}$ ratios from the ventral margin of the shell - where mantle metabolic rate is lower, towards the shell's lateral margin, where intra-cellular transport dominates (Rosenberg and Hughes, 1991), meaning higher metabolic rate and lower Sr/Ca ratios.

Overall, there is no conclusive evidence that $\mathrm{Mg}$ or $\mathrm{Sr}$ incorporation in calcitic or aragonitic mollusc shells is under thermodynamic control so as to make either of these useful proxies for deriving paleo-ocean temperatures. Where the incorporation of these elements in shells appears to be related to temperature, it is more likely that this is an indirect effect. Temperature may influence the biological and physiological processes responsible for mineralization, specifically growth rate, metabolic pumping, and crystallographic properties of $\mathrm{CaCO}_{3}{ }^{-}$, which appear to be the dominant control on $\mathrm{Mg}$ and $\mathrm{Sr}$ incorporation. Unravelling these physiological signals for a species may allow $\mathrm{Sr} / \mathrm{Ca}$ and $\mathrm{Mg} / \mathrm{Ca}$ records to be potential proxies for SST (Schöne, 2008; Schöne, 2011).

An additional question remains about the possible correlation between $\mathrm{Mg} / \mathrm{Ca}$ shell chemistry and $\mathrm{Sr}$ incorporation. It is proposed that when $\mathrm{Mg}^{2+}$ substitutes for $\mathrm{Ca}^{2+}$ in the crystal lattice, a distortion is created in the lattice because of the smaller ionic radius of $\mathrm{Mg}^{2+}$ thus creating more space in adjacent areas of the lattice for substitution by a larger ion, such as $\mathrm{Sr}^{2+}$ (Mucci and Morse, 1983; Goldsmith et al., 1961; Vander Putten et al.; 2000). 
Table 1.1 Summary of key studies of $\mathrm{Mg}$ incorporation in molluscan shells. For each study, the species, location of individuals studied, polymorph of $\mathrm{CaCO}_{3}$ and result for the incorporation of $\mathrm{Mg}$ are reported.

\begin{tabular}{|c|c|c|c|c|}
\hline Study & Species & Location & Proxy & Result \\
\hline Dodd (1965) & $\begin{array}{l}\text { Mytilus edulis } \\
\text { Mytilus } \\
\text { californianus }\end{array}$ & $\begin{array}{l}\text { Pacific Coast } \\
\text { from } \\
\text { Washington } \\
\text { to southern } \\
\text { California }\end{array}$ & $\mathrm{Mg} / \mathrm{Ca}$ calcite & $\begin{array}{l}\text { Weak positive correlation } \\
\text { with temperature - likely } \\
\text { related to changes in growth } \\
\text { rate }\end{array}$ \\
\hline $\begin{array}{l}\text { Klein et al. } \\
\text { (1996) }\end{array}$ & Mytilus trossulus & $\begin{array}{l}\text { Strait of } \\
\text { Georgia, } \\
\text { British } \\
\text { Columbia }\end{array}$ & $\mathrm{Mg} / \mathrm{Ca}$ calcite & $\begin{array}{l}\text { Positive correlation with } \\
\text { temperature }\end{array}$ \\
\hline $\begin{array}{l}\text { Vander Putten } \\
\text { et al. }(2000)\end{array}$ & Mytilus edulis & $\begin{array}{l}\text { The } \\
\text { Netherlands }\end{array}$ & $\mathrm{Mg} / \mathrm{Ca}$ calcite & $\begin{array}{l}\text { Positive correlation between } \\
\text { with temperature only } \\
\text { during spring }\end{array}$ \\
\hline $\begin{array}{l}\text { Carré et al. } \\
(2006)\end{array}$ & $\begin{array}{l}\text { Mesodesma } \\
\text { donacium } \\
\text { Chione subrugosa }\end{array}$ & $\begin{array}{l}\text { Peruvian } \\
\text { Coast }\end{array}$ & $\begin{array}{l}\mathrm{Mg} / \mathrm{Ca} \\
\text { aragonite }\end{array}$ & $\begin{array}{l}\text { Positive correlation with } \\
\text { calcification rate }\end{array}$ \\
\hline $\begin{array}{l}\text { Takesue and } \\
\text { van Geen } \\
(2004)\end{array}$ & $\begin{array}{l}\text { Protothaca } \\
\text { staminea }\end{array}$ & $\begin{array}{l}\text { Humboldt } \\
\text { Bay, } \\
\text { northern } \\
\text { California }\end{array}$ & $\begin{array}{l}\mathrm{Mg} / \mathrm{Ca} \\
\text { aragonite }\end{array}$ & $\begin{array}{l}\text { Positive correlation with } \\
\text { temperature in one growth } \\
\text { increment. Diagenetic } \\
\text { decrease in } \mathrm{Mg} / \mathrm{Ca} \text { in fossils } \\
\text { of the species }\end{array}$ \\
\hline $\begin{array}{l}\text { Schöne et al. } \\
\text { (2011) }\end{array}$ & Arctica islandica & Iceland & $\begin{array}{l}\mathrm{Mg} / \mathrm{Ca} \\
\text { aragonite }\end{array}$ & $\begin{array}{l}\text { Strong negative correlation } \\
\text { with growth rate, positive } \\
\text { correlation with ontogenetic } \\
\text { age } \\
\text { Growth rate-detrended } \\
\text { ratios inversely correlated to } \\
\text { SST }\end{array}$ \\
\hline $\begin{array}{l}\text { Elliot et al. } \\
\text { (2009) }\end{array}$ & Tridacna gigas & $\begin{array}{l}\text { San } \\
\text { Francisco } \\
\text { Bay, } \\
\text { California }\end{array}$ & $\begin{array}{l}\mathrm{Mg} / \mathrm{Ca} \\
\text { Aragonite }\end{array}$ & $\begin{array}{l}\text { SST causes seasonal } \mathrm{Mg} / \mathrm{Ca} \\
\text { variations, but ratios cannot } \\
\text { be quantitatively linked to } \\
\text { SST Positive correlation } \\
\text { with ontogenetic age }\end{array}$ \\
\hline
\end{tabular}


Table 1.2 Summary of key studies of Sr incorporation in molluscan shells. For each study, the species, location of individuals studied, polymorph of $\mathrm{CaCO}_{3}$ and result for the incorporation of $\mathrm{Sr}$ are reported.

\begin{tabular}{|c|c|c|c|c|}
\hline Study & Species & Location & Proxy & Result \\
\hline Dodd (1965) & $\begin{array}{l}\text { Mytilus edulis } \\
\text { Mytilus } \\
\text { californianus }\end{array}$ & $\begin{array}{l}\text { Pacific Coast } \\
\text { from } \\
\text { Washington } \\
\text { to southern } \\
\text { California }\end{array}$ & $\mathrm{Sr} / \mathrm{Ca}$ aragonite & $\begin{array}{l}\text { Positive correlation with } \\
\text { temperature } \\
\text { Negative correlation with } \\
\text { temperature }\end{array}$ \\
\hline $\begin{array}{l}\text { Lorens and } \\
\text { Bender (1980) }\end{array}$ & Mytilus trossulus & $\begin{array}{l}\text { Grown in } \\
\text { laboratory }\end{array}$ & $\mathrm{Sr} / \mathrm{Ca}$ calcite & $\begin{array}{l}\text { Linear increase in } \mathrm{Sr} / \mathrm{Ca} \text { with } \\
\text { water } \mathrm{Sr} / \mathrm{Ca} \text { ratios }\end{array}$ \\
\hline $\begin{array}{l}\text { Klein et al. } \\
\text { (1996) }\end{array}$ & Mytilus trossulus & $\begin{array}{l}\text { Strait of } \\
\text { Georgia, } \\
\text { British } \\
\text { Columbia }\end{array}$ & $\mathrm{Sr} / \mathrm{Ca}$ aragonite & $\begin{array}{l}\text { Ratios vary with metabolic } \\
\text { efficiency of } \mathrm{Ca}^{2+} \text { pumping }\end{array}$ \\
\hline $\begin{array}{l}\text { Vander Putten } \\
\text { et al. }(2000)\end{array}$ & Mytilus edulis & $\begin{array}{l}\text { The } \\
\text { Netherlands }\end{array}$ & $\mathrm{Sr} / \mathrm{Ca}$ calcite & $\begin{array}{l}\text { Positive correlation with } \\
\text { calcification rate }\end{array}$ \\
\hline $\begin{array}{l}\text { Lorrain et al. } \\
(2005)\end{array}$ & Pecten maximus & $\begin{array}{l}\text { Bay of Brest, } \\
\text { France }\end{array}$ & $\mathrm{Sr} / \mathrm{Ca}$ calcite & $\begin{array}{l}\text { Positive correlation with } \\
\text { calcification rate }\end{array}$ \\
\hline $\begin{array}{l}\text { Takesue and } \\
\text { van Geen } \\
(2004)\end{array}$ & Protothaca staminea & $\begin{array}{l}\text { Humboldt } \\
\text { Bay, northern } \\
\text { California }\end{array}$ & $\mathrm{Sr} / \mathrm{Ca}$ aragonite & $\begin{array}{l}\text { Positive correlation with } \\
\text { calcification rate }\end{array}$ \\
\hline $\begin{array}{l}\text { Gillikin et al. } \\
(2005)\end{array}$ & Saxidomus giganteus & $\begin{array}{l}\text { Washington } \\
\text { and Alaska }\end{array}$ & $\mathrm{Sr} / \mathrm{Ca}$ aragonite & $\begin{array}{l}\text { Positive correlation with } \\
\text { calcification rate }\end{array}$ \\
\hline $\begin{array}{l}\text { Carré et al. } \\
(2006)\end{array}$ & $\begin{array}{l}\text { Mesodesma } \\
\text { donacium } \\
\text { Chione subrugosa }\end{array}$ & $\begin{array}{l}\text { Peruvian } \\
\text { Coast }\end{array}$ & $\mathrm{Sr} / \mathrm{Ca}$ aragonite & $\begin{array}{l}\text { Positive correlation with } \\
\text { calcification rate }\end{array}$ \\
\hline $\begin{array}{l}\text { Elliot et al. } \\
(2009)\end{array}$ & Tridacna gigas & $\begin{array}{l}\text { San } \\
\text { Francisco } \\
\text { Bay, } \\
\text { California }\end{array}$ & $\mathrm{Sr} / \mathrm{Ca}$ aragonite & $\begin{array}{l}\text { SST growth rates and } \\
\text { metabolic rates do NOT } \\
\text { control } \mathrm{Sr} / \mathrm{Ca} \text { ratios }\end{array}$ \\
\hline \multirow[t]{2}{*}{$\begin{array}{l}\text { Schöne et al } \\
\text { (2011) }\end{array}$} & \multirow[t]{2}{*}{ Arctica islandica } & \multirow[t]{2}{*}{ Iceland } & \multirow[t]{2}{*}{$\mathrm{Sr} / \mathrm{Ca}$ aragonite } & $\begin{array}{l}\text { Strong negative correlation } \\
\text { with growth rate, positive } \\
\text { correlation with ontogenetic } \\
\text { age }\end{array}$ \\
\hline & & & & $\begin{array}{l}\text { Age-detrended ratios inversely } \\
\text { correlated to SST }\end{array}$ \\
\hline
\end{tabular}




\subsection{2 $\mathrm{Ba} / \mathrm{Ca}$ and $\mathrm{Mn} / \mathrm{Ca}$ : Indicators of primary productivity, salinity and redox?}

The residence time of $\mathrm{Ba}$ in the ocean is only 0.01 Myr (Paytan et al., 2007), and therefore the concentration of $\mathrm{Ba}$ in seawater depends strongly on local influences over short timescales. In particular, it is well known that high primary productivity increases seawater Ba levels (Goldberg and Arrhenius, 1958; Chow and Goldberg, 1960; Dehairs et al., 1980; Dehairs et al., 1987; Bishop, 1988). Sediment run-off greatly affects the Ba concentration of seawater in coastal locations, especially those sites vulnerable to flood plumes. High resolution analyses of aragonitic coral skeletons from the Great Barrier Reef have shown that $\mathrm{Ba} / \mathrm{Ca}$ variations provide a record of storm events, as well as quantifying erosion relating to land use change in eastern Queensland, and information on the terrigenous sources of $\mathrm{Ba}$ (McCulloch et al., 2003; Sinclair and McCulloch, 2004).

Analyses of $\mathrm{Ba} / \mathrm{Ca}$ ratios in bivalves to date have revealed low background concentrations interspersed with periodic peaks of elevated $\mathrm{Ba} / \mathrm{Ca}$ (Vander Putten et al., 2000; Stecher et al., 1996; Gillikin et al., 2006; Lazareth et al., 2003; Gillikin et al., 2008). Vander Putten et al. (2000) suggested that the peaks observed in Mytilus edulis shells were due to phytoplankton blooms, based on the their coincidence with observed spring-time blooms and peaks in chlorophyll. However, it was noted that the $\mathrm{Ba} / \mathrm{Ca}$ chlorophyll correlation was not year long, limiting shell $\mathrm{Ba} / \mathrm{Ca}$ as a proxy for primary productivity. Likewise, Stecher et al. (1996) attributed Ba/Ca peaks in Mercenaria mercenaria and Spisula solidissima to local diatom blooms increasing levels of particulate $\mathrm{Ba}$, which were then ingested by the bivalves. Gillikin et al. (2008) found that synchronous $\mathrm{Ba} / \mathrm{Ca}$ peaks in two Saxidomus giganteus bivalves and four Pecten maximus scallops were not fully explained by phytoplankton blooms. Although these $\mathrm{Ba} / \mathrm{Ca}$ peaks occurred near peaks in the chlorophyll record, there was a month long 
delay between the $\mathrm{Ba} / \mathrm{Ca}$ peaks forming and the 'crash' of the phytoplankton bloom. Additionally, the amplitude of chlorophyll and $\mathrm{Ba} / \mathrm{Ca}$ peaks were not correlated. Another potential cause of the $\mathrm{Ba} / \mathrm{Ca}$ peaks in $P$. maximus postulated by Gillikin et al. (2008) was the effect of the scallop's reproductive cycle on $\mathrm{Ba} / \mathrm{Ca}$ incorporation- as peaks coincided with times when the scallops were not spawning.

Gillikin et al. (2006) used field and laboratory experiments to examine the $\mathrm{Ba} / \mathrm{Ca}$ ratios observed in $M$. edulis excluding the Ba/Ca peaks (the "background" signal). These authors found that background $\mathrm{Ba} / \mathrm{Ca}$ shell ratios were directly related to, and thus could be used as a proxy for the $\mathrm{Ba} / \mathrm{Ca}$ ratios of the seawater in which the shells crystallised. This is consistent with some previous studies on corals that showed bulk chemistry $\mathrm{Ba} / \mathrm{Ca}$ ratios were related to seawater $\mathrm{Ba} / \mathrm{Ca}$ ratios (Bowen, 1956; Harris and Almy, 1964; Livingston and Thompson, 1971), and an earlier study by Torres et al. (2001) that found a correlation between $\mathrm{Ba} / \mathrm{Ca}$ ratios in clam shells and seawater $\mathrm{Ba} / \mathrm{Ca}$. Gillikin et al. (2006) argued that in estuarine mussels the shell $\mathrm{Ba} / \mathrm{Ca}$-seawater proxy could be extended to provide a relative record of salinity, because of estuarine-specific relationships between salinity and seawater Ba/Ca (Gillikin et al., 2006; Coffey et al., 1997). However, for S. giganteus bivalves, Gillikin et al. (2008) conceded that ontogenetic decrease in background $\mathrm{Ba} / \mathrm{Ca}$ ratios complicated the use of that particular species for a salinity proxy. A. stutchburyi clams, also filter feeders, were collected for this study from a mixture of estuarine and open ocean sites; thus the $\mathrm{Ba} / \mathrm{Ca}$ ratios measured in their shells could shed light on Ba incorporation, and the potential of the proxies discussed above.

Like barium, manganese also has a very short ocean residence time - 760 yr (Savenko, 2008). It is sourced in dissolved form $\left(\mathrm{Mn}^{2+}\right)$ from riverine input of terrigenous sediment, and once in the ocean is oxidised to $\mathrm{Mn}^{4+}$. In anoxic conditions, $\mathrm{Mn}^{2+}$ can be 
recycled through reduction, and there are high amounts of Mn found in ocean floor sediment. There is evidence to suggest that the concentration of particulate $\mathrm{Mn}$ in seawater is associated with primary productivity due to algae taking up dissolved Mn, and certain phytoplankton catalysing the oxidation of Mn to form insoluble Mn oxides (Morris, 1971; Sunda and Huntsman, 1985; Vander Putten, 2000). Several records of $\mathrm{Mn} / \mathrm{Ca}$ in bivalves have shown correlated peaks with $\mathrm{Ba} / \mathrm{Ca}$, and have likewise been correlated to chlorophyll concentrations (Vander Putten et al., 2000; Lazareth et al., 2003). Freitas et al. (2006), however, found that variations of $\mathrm{Mn} / \mathrm{Ca}$ in P. maximus bivalves in Menai Strait were more closely related to hydrographical conditions, specifically changes in temperature and redox conditions, which affected the seawater dissolved $\mathrm{Mn}^{2+}$. These authors suggested, therefore, that the bivalve was a potential proxy for seawater $\mathrm{Mn}^{2+}$.

As is the case for $\mathrm{Ba} / \mathrm{Ca}$ ratios, the $\mathrm{Mn} / \mathrm{Ca}$ ratios in molluscan shells, and their potential use as a proxy, are likely to vary for a given species depending on the environment the mollusc lives in, and the local influences on Mn seawater concentration. Differences observed between individuals of a species grown in the same conditions suggest that $\mathrm{Mn} / \mathrm{Ca}$ and $\mathrm{Ba} / \mathrm{Ca}$ are also biologically influenced, which would require further research to disentangle from the environmental influence (Freitas et al., 2006). Calcification (growth rate) is likely to be one such influence; Carré et al. (2006) found this physiological process accounted for $54 \%$ of $\mathrm{Mn} / \mathrm{Ca}$ ratio variations and $44 \%$ of $\mathrm{Ba} / \mathrm{Ca}$ ratio variations in $M$. donacium shells.

\subsubsection{As, Zn, Cu \& Pb: Tracers of pollution?}

Purchase and Fergusson (1986) analysed $\mathrm{Pb}$ concentrations in the shell of A. stutchburyi living on the Heathcoate River, Christchurch, where anthropogenic pollution of $\mathrm{Pb}$ had previously been linked to a nearby battery factory and traffic. It was found that $\mathrm{Pb}$ 
concentrations varied across sections of shells; with higher concentrations in the sections close to the umbo (that grew when the clam was young), suggesting incorporation of $\mathrm{Pb}$ into the shell may depend on age (or possibly changes in growth rate dependent on seasonality and age). If this effect is confirmed in A. stutchburyi in this study for other heavy trace metals $(\mathrm{Zn}, \mathrm{As}, \mathrm{Cu})$, it would complicate the use of the clams as pollutant indicators, because ontogenetic, or growth related variations in heavy metal concentration could be mistaken for environmental ones. In other bivalves, variations in concentrations of $\mathrm{Cu}, \mathrm{Zn}$ and $\mathrm{Cd}$ have been linked to pollution (Richardson, 2001).

\subsection{Sclerochronology: Bivalve microstructure \& growth information}

Growth information is of vital importance in interpreting molluscan geochemical records for several reasons. First, when growth lines on a species are known to represent certain increments of time a timescale can be assigned to the section of shell. This process is termed sclerochronology. Second, understanding the growth characteristics in the species under study is crucial. Growth may influence the incorporation of trace elements (e.g. for $\mathrm{Sr} / \mathrm{Ca}$ ratios as described above), and furthermore it is important to identify any periods of growth cessation so that potential interruptions in the geochemical record can be identified. For example, it has been found that the Arctica islandica clam does not deposit any shell for two months when it is spawning, and the interpretation of environmental information recorded in its shell must take into account this gap (Schöne et al., 2005).

\subsubsection{Shell microstructure}

Bivalve shells are divided into two, or sometimes three, calcified layers, and one thin, organic outer layer called the periostracum (Figure 1.1). The calcified layers are largely comprised of a microstructure of $\mathrm{CaCO}_{3}$ crystals with a particular orientation, shape and 
size. There are seven possible microstructure types, some of which are associated exclusively with either aragonite or calcite, and others which are found in both these polymorphs of calcium carbonate (Carter, 1980; Gregoire, 1972). Each species has a unique configuration of microstructures and polymorphs, and more than one microstructure has been found in a particular layer. Within the mineral layers of the shell there are also two organic components present: an intra-crystalline organic matrix, which binds the $\mathrm{CaCO}_{3}$ crystals; and an extra-crystalline organic layer, which separates individual increments of crystal growth. The latter organic layer forms during times when the organism's valves are closed and an increase in acidity of the EPF dissolves the previously deposited organic matrix and $\mathrm{CaCO}_{3}$. (Panella, 1975; Palmer, 1995; Takesue and van Geen, 2004).

\subsubsection{A. stutchburyi microstructure}

A. stutchburyi shells are comprised of three calcified layers: an outer layer with a crossed-lamellar microstructure; an inner layer of homogeneous (irregularly shaped and arranged) crystals; and an inner layer with complex cross lamellar or homogeneous structure. (Jones, 1979; Figure 1.5). The geochemical analyses completed in this study transverse the outer crossed-lamellar layer, which is made of elongate, aragonite crystals (Kobayashi and Samata, 2006; Purchase and Fergusson, 1986).

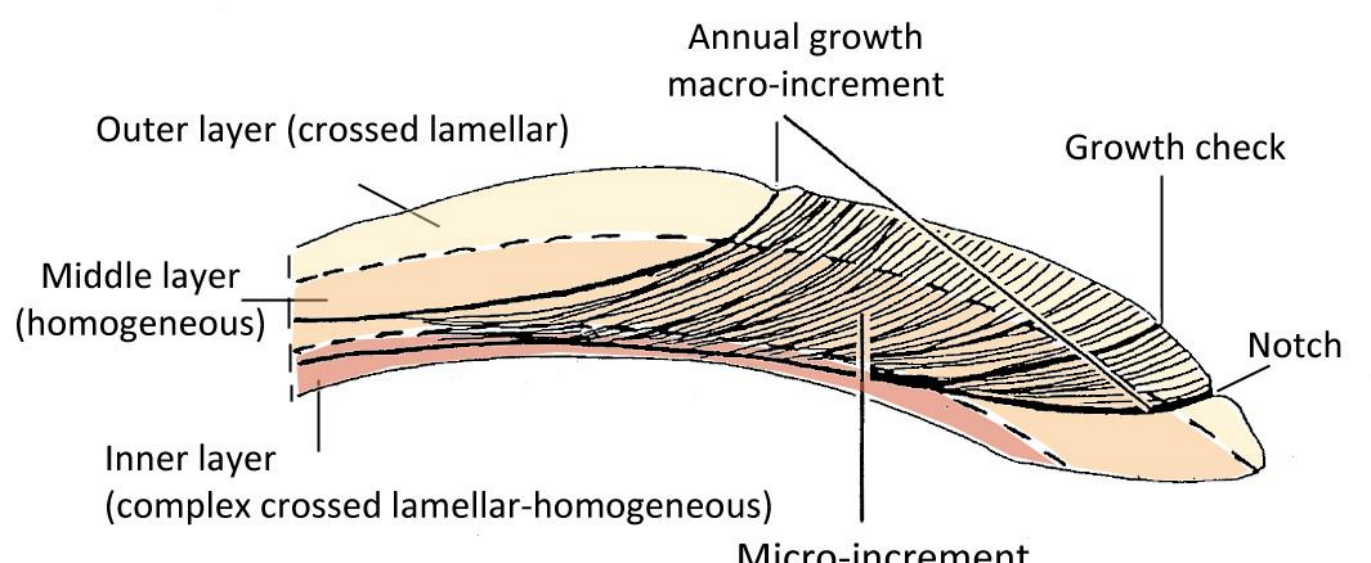

Figure 1.5 Schematic cross-section of A. stutchburyi shell showing growth patterns (micro- and macro- increments) and zones of different shell microstructure (crossed-lamellar, homogeneous and complex crossed-lamellar). Figure modified from McKinnon, 1996). 


\subsubsection{Growth increments}

Growth increments are discrete sections of shell, identifiable by extra-crystalline organic layers, and represent a defined period of growth. There are commonly two types of increments found in bivalves: macro-increments - sometimes referred to as growth-bands or rings; and micro-increments - sometimes termed growth-lines (Figure 1.5). Here, the terminology macro- and micro-increment will be used. Macroincrements are defined by two thick, dark bands, which result from a slowdown of shell growth, or complete stop in carbonate deposition. In many species, it has been shown that these are an annual phenomenon, and form seasonally during periods of no deposition. However, similar bands may also be formed in response to an abrupt termination of growth caused by environmental or physiological stress, such as storms or spawning (Schöne, 2008). Annual bands, and thus macro-increments, can be distinguished from stress bands in some bivalves because they are often accompanied by a notch at the shell surface, whereas stress bands often do not extend all the way through the section of shell as shell growth abruptly commences. (Panella, 1975; Takesue and van Geen, 2004; McKinnon, 1996; Clark, 1979).

Micro-increments are defined by fine layers of extra-crystalline organic material, deposited, as discussed above, when valves are closed. In many sub-tidal and intertidal species the increments are related to the cycle of the tides - as valves close and shell growth slows or stops when shells are not immersed during low tide (Kanazawa and Sato, 2008; Takesue and van Geen, 2004; Carré et al., 2005; Carré et al., 2006). However, there is commonly not a one-to-one correlation between low tide events and micro-increments, with seasonality, as well as spring tide and neap tide cycling influencing the size and number of increments formed in a lunar day (McKinnon, 1996; Evans, 1972; Richardson et al., 1990; Takesue and van Geen, 2004). 


\subsubsection{Growth increments in A. stutchburyi}

McKinnon (1996) carried out an extensive study on the growth characteristics of $A$. stutchburyi growing at Port Chalmers in Dunedin. The study confirmed the results of an earlier experiment by Coutts (1974) that macro-increments in the clams have an annual period, with the bands forming during the winter months. In some specimens, stress bands were also observed, which form in the summer months during spawning. Annual bands could be distinguished from stress bands in the manner described above; the annual bands being associated with a notch or depression at the shell surface, and the stress bands commonly being incomplete through the shell (McKinnon, 1996).

Micro-increments in A. stutchburyi have a tidal influence that is modulated by other changes in growth rate. McKinnon (1996) found a one-to-one correlation between the number of low tides and the number of micro-increments laid down during the peak growing season only (January and February). However, it appears during the remainder of the year that fewer micro-increments form than there are low tides, and that in June and July only a very small number, or no micro-increments are produced. This is consistent with other studies where low growth rate for an extended period of time produced an increment of shell without distinguishable micro-rings (Jones 1980).

There is also a cyclical variation between A. stutchburyi increments added in spring tides, and neap tides, which vary four times during a lunar cycle. During spring tides, when shells are immersed for longer periods of time, the micro-increments are wider; with two strong boundaries separating each increment, and a thin boundary, barely visible, in the centre of each increment as well (Figure 1.6). Conversely, during neap tides the micro-increments are narrower and are defined by only two strong organic boundaries (McKinnon, 1996). 


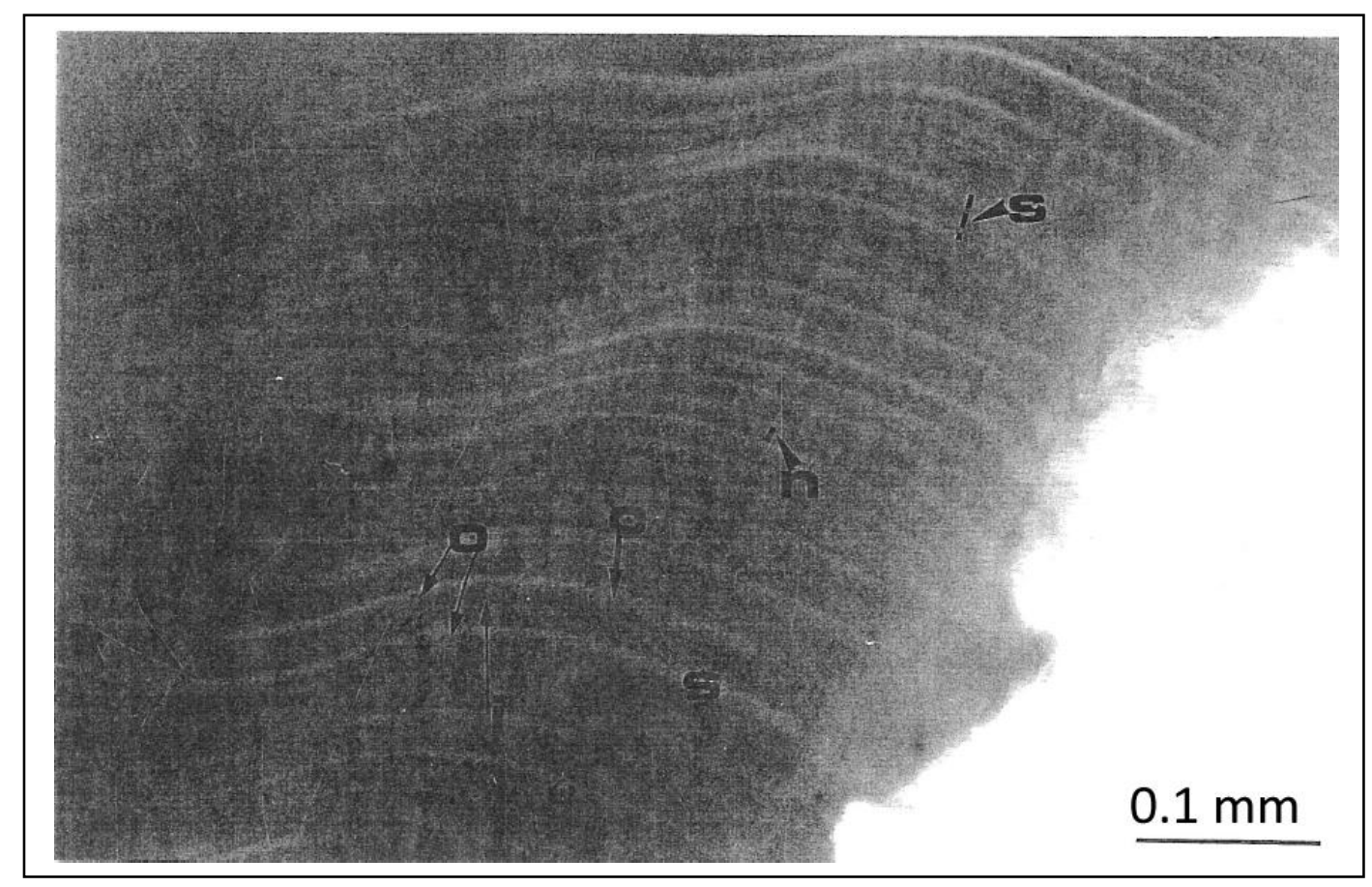

Figure 1.6 Photograph showing the difference between spring tide micro-increments (S), which have strong outer organic boundaries $(\mathrm{O})$ and weak inner boundaries $(\mathrm{C})$. Neap tide micro-increments are narrower (N) Taken from (McKinnon 1996).

The fact that micro-increments on A. stutchburyi do not form with every low tide and that they are not formed at all during much of the winter has significant ramifications for geochemical studies utilising the clam. It means that geochemical records taken across a section in the shell may be incomplete, with an underestimation of the winter signal.

\subsubsection{Factors affecting A. stutchburyi growth}

Besides tidal influence on growth, there are other factors driving growth rate that explain why micro-increments do not perfectly correlate with the number of low tides. Temperature, associated with latitudinal location, is the predominant environmental influence known to affect shell growth rates (Green, 1973; Richardson et al., 1980; Fox and Coe, 1943; Dodd, 1964). Other environmental conditions, such as storms, increases in silty sediment (Appledoorn, 1983), variations in salinity (Marsden, 2004), and 
availability of food, have all been shown to cause a slow down or cessation in growth in particular species. In addition, biological factors also have an impact on growth rate; it is common that growth rate slows during spawning and also with ontogenetic maturity or age (Hall, 1974; Jones, 1978).

McKinnon (1996) demonstrated that in A. stutchburyi, the cessation of growth coincides with the winter months, when temperatures are lowest. Comparing growth rate measurements with recorded sea surface temperatures for the whole year also revealed a strong correlation between the two parameters $\left(r^{2}=0.624\right)$. The hours of light in each day (i.e. day length) were also shown to correlate to growth rate. Marsden (2004) has shown that $A$. stutchburyi are very sensitive to salinity dilution, which together with low phytoplankton availability, reduces growth and condition of the clams. McKinnon (1996) found that the stress band seen in some individuals in summer responded to the clams' spawning activity during this time. Finally, a growth-rate model developed by McKinnon (1996) shows that A. stutchburyi growth rate slows exponentially with age (Figure 1.7).

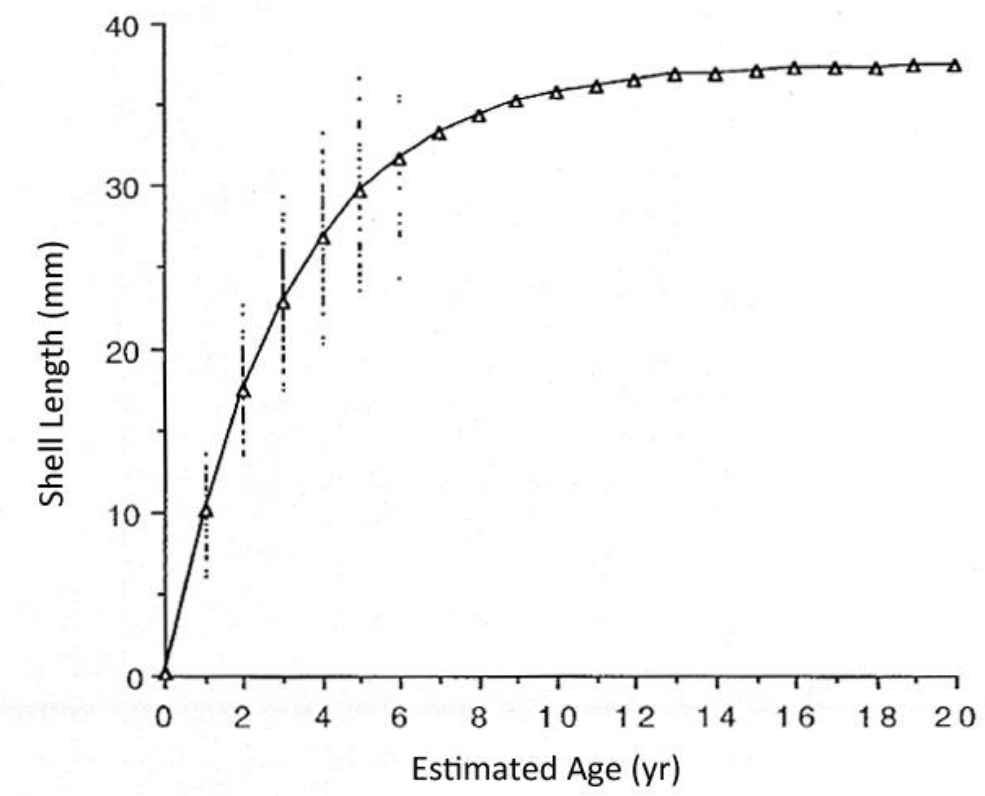

Figure 1.7 Growth rate and age model for A. stutchburyi. Figure taken from McKinnon (1996). 


\subsection{Thesis Structure}

Chapter One: Introduction outlines the incorporation of trace elements in molluscs and their potential as environmental proxies; and the thesis objectives.

Chapter Two: Materials and Methods introduces the study species; field sites where samples were collected; sample preparation; sample analyses; how data were processed; and discusses analytical uncertainties.

Chapter Three: Results presents the trace element records for each shell analysed plotted against distance sectioned; correlation matrix between particular trace element/Ca ratios; average shell TE/Ca ratios; and sediment trace element values.

\section{Chapter Four: Discussion}

1. A. stutchburyi sclerochronology: Describes the methods used to produce a chronology for two of the shell sections analysed and discusses the limitations and methods in using sclerochronology.

2. Trace element incorporation: Reports growth rate results, and shows this is the primary influence on TE incorporation. Individual influences on incorporation are discussed for $\mathrm{Mg} / \mathrm{Ca}, \mathrm{Sr} / \mathrm{Ca}, \mathrm{Mn} / \mathrm{Ca}, \mathrm{Ba} / \mathrm{Ca}, \mathrm{U} / \mathrm{Ca}, \mathrm{As} / \mathrm{Ca}, \mathrm{Zn} /$ $\mathrm{Ca}$ and $\mathrm{Cu} / \mathrm{Ca}$ in light of temporal variation in order to evaluate the suitability of using trace elements in A. stutchburyi as paleoenvironmental proxies.

3. Comparison with other molluscan studies: Places the results and interpretations for A. stutchburyi in context with previous mollusc TE/Ca studies.

4. Evaluation of A. stutchburyi: Discusses the usefulness and limitations of using A. stutchburyi clams as paleoenvironment indicators.

Chapter Five: Conclusions outlines the key conclusions reached in the study, and makes suggestions for further study. 


\section{CHAPTER 2.0 MATERIALS AND METHODS}

\subsection{Study species: A. stutchburyi}

Austrovenus stutchburyi (Wood, 1828), commonly referred to as the New Zealand cockle, is a clam from the family Veneridae. The species is a shallow-burrowing (20-40 $\mathrm{mm}$ beneath the sediment surface), filter-feeder that is found in soft mud to fine-grained sand in sheltered beaches, tidal flats and estuaries, with larger specimens usually found in coarser-grained sediment. (Beu, 2006; Powell, 1979; Jones, 1983; New Zealand Ministry of Fisheries, 2010). A. stutchburyi is an intertidal bivalve, with an endogenous tidal rhythm of shell gaping and siphon extension (Beentjes \& Williams, 1986). Therefore, the clam's habitat is generally limited by the lowest neap-tide mark, and the highest spring-tide mark (Beu, 2006; Dobinson et al., 1989), although Larcombe (1971) has reported animals higher in the intertidal zone that are submerged for only 3.5 $\mathrm{hr}$ in a day. Salinity, phytoplankton availability, and temperature have a strong control on growth rate and survival, as described in the previous chapter. A. stutchburyi typically live for $10 \mathrm{yr}$, and for older specimens it is thought that little shell extension occurs after $10 \mathrm{yr}$ (McKinnon, 1996).

The species is widespread in the North and South Islands of New Zealand, as well as Stewart and the Chatham Islands. Population densities can be very high - as many as 4500 A. stutchburyi per square metre have been recorded (New Zealand Ministry of Fisheries, 2010). Preserved A. stutchburyi shells are commonly present in large numbers throughout the New Zealand fossil record, dating as far back as the late Pliocene (Beu, 2006). The species has been used to date shoreline progression from the end of the last glacial period through the Holocene (Heap \& Nichol, 1997; Kennedy, 2008), and shells found in Maori middens deposits have been dated for archaeological 
studies (Higham and Hogg, 1997). Its abundance at a range of latitudes and preservation in the fossil record make A. stutchburyi a prime molluscan species candidate for paleoenvironment studies.

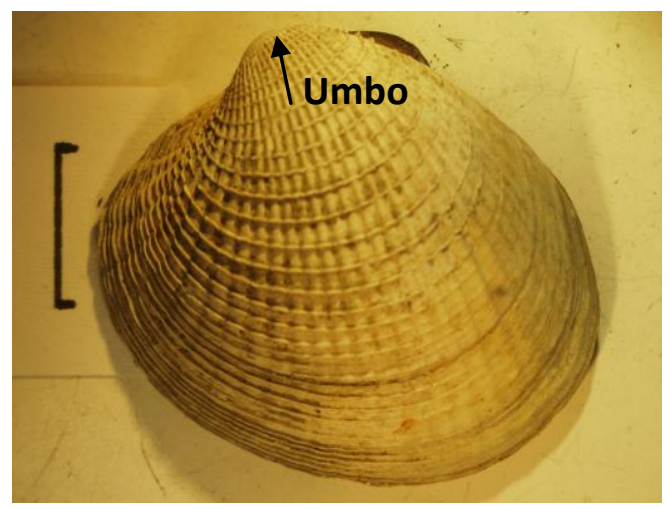

Figure 2.1 Photograph showing one valve of $A$. stutchburyi collected at Manakau Harbour. Scale bar is $1 \mathrm{~cm}$ long.

\subsection{Sampling Locations}

A. stutchburyi and sediment samples were collected from eight sites - one in the South Island and seven in the North Island (Table 2.1 and Figure 2.2). The locations were spread over a range of latitudes and a variety of coastal settings: estuarine (Kawhia); tidal mud-flats (Miranda, Bay of Islands, Manakau); and an open ocean beach (Ligar Bay). Therefore, variability in ocean temperature, and between mixed and closed seawater conditions, may have potentially been recorded in the shell chemistry. Also, the locations encompassed a range of geographic settings - specifically land usage and population density.

One shell per location was analysed by LA-ICP-MS, with the exception of Ligar Bay where four shells were analysed. In addition, one shell was analysed from the Ligar Estuary - an estuary adjoining Ligar Bay. In this way, the geochemical variability between individuals experiencing the same environmental conditions could be compared (between the Ligar Bay samples), and the difference between estuarine and open sea individuals living in similar conditions (Ligar Bay and Ligar Estuary) could be 
assessed. Samples from these latter two locations were collected at the same time in April 2008, while samples from the remaining sites were collected over a week in January 2009.
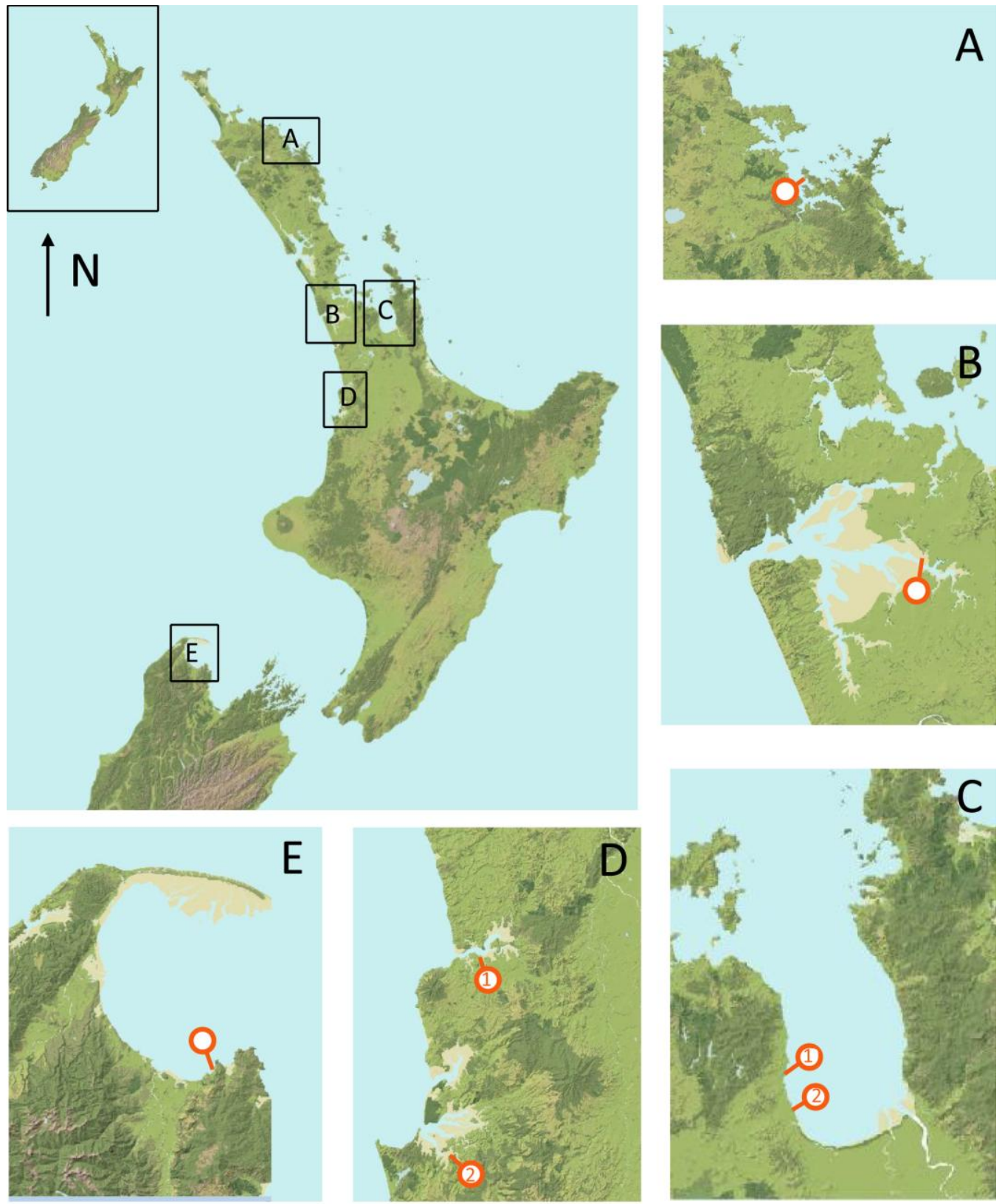

Figure 2.2 Map of sample locations of where A. stutchburyi were collected from in New Zealand, and small maps showing individual locations indicated by orange circles. A Pomare Bay, Bay of Islands; B Manakau Harbour; C Firth of Thames $\mathbf{1}$ Kaiaua 2 Miranda; D 1 Raglan 2 Kawhia; E Ligar Bay and Ligar Estuary. Maps modified from GeographX map of New Zealand. 
Table 2.1 Summary of field locations where A. stutchburyi were sampled from. Site name, date sampled, latitude and longitude of the sample location, the coastal setting and catchment setting are reported.

\begin{tabular}{|c|c|c|c|c|}
\hline Site & Date Samplec & Latitude/longitude & Coastal setting & Catchment setting \\
\hline Ligar Bay & 1 April 2008 & $\begin{array}{l}40^{\circ} 49^{\prime} 22.47 " \mathrm{~S}, \\
172^{\circ} 54^{\prime} 15.12^{\prime \prime} \mathrm{E}\end{array}$ & $\begin{array}{l}\text { Open ocean, } \\
\text { beach with } \\
\text { medium-coarse } \\
\text { sand }\end{array}$ & $\begin{array}{l}\text { Granite; Oligocene- } \\
\text { Miocene limestone }\end{array}$ \\
\hline $\begin{array}{l}\text { Ligar } \\
\text { Estuary }\end{array}$ & 1 April 2008 & $\begin{array}{l}40^{\circ} 49^{\prime} 22.47 " \mathrm{~S}, \\
172^{\circ} 54^{\prime} 15.12^{\prime \prime} \mathrm{E}\end{array}$ & Estuarine & $\begin{array}{l}\text { Granite; Oligocene- } \\
\text { Miocene limestone }\end{array}$ \\
\hline Kawhia & 20 Jan 2009 & $\begin{array}{l}38^{\circ} 2^{\prime} 48.39^{\prime \prime} \mathrm{S}, \\
174^{\circ} 49^{\prime} 53.75^{\prime \prime} \mathrm{E}\end{array}$ & $\begin{array}{l}\text { Estuarine, mud } \\
\text { flats }\end{array}$ & $\begin{array}{l}\text { Oligocene limestone; } \\
\text { Early Quaternary } \\
\text { andesite; Jurassic } \\
\text { greywacke }\end{array}$ \\
\hline Raglan & 21 Jan 2009 & $\begin{array}{l}37^{\circ} 47^{\prime} 45.22^{\prime \prime S}, \\
174^{\circ} 52^{\prime} 13.63^{\prime \prime} \mathrm{E}\end{array}$ & $\begin{array}{l}\text { Mud flat within } \\
\text { harbour entrance, } \\
\text { mud-fine grained } \\
\text { sand }\end{array}$ & $\begin{array}{l}\text { Oligocene limestone; } \\
\text { Early Quaternary } \\
\text { andesite }\end{array}$ \\
\hline Miranda & 22 Jan 2009 & $\begin{array}{l}37^{\circ} 8^{\prime} 55.20^{\prime \prime} \mathrm{S}, \\
175^{\circ} 18^{\prime} 37.81 " \mathrm{E}\end{array}$ & Tidal mud-flats & $\begin{array}{l}\text { Quaternary post- } \\
\text { glacial alluvium; } \\
\text { Quaternary swamp } \\
\text { deposits and peat; } \\
\text { Jurassic greywacke; } \\
\text { Miocene andesite }\end{array}$ \\
\hline Kaiaua & 22 Jan 2009 & $\begin{array}{l}37^{\circ} 6^{\prime} 43.25^{\prime \prime S}, \\
175^{\circ} 17^{\prime} 52.90 " \mathrm{E}\end{array}$ & $\begin{array}{l}\text { Beach with mud- } \\
\text { fine sand, } \\
\text { including broken } \\
\text { shell fragments }\end{array}$ & $\begin{array}{l}\text { Quaternary post- } \\
\text { glacial alluvium; } \\
\text { Quaternary swamp } \\
\text { deposits and peat; } \\
\text { Jurassic greywacke; } \\
\text { Miocene andesite }\end{array}$ \\
\hline Manakau & 22 Jan 2009 & $\begin{array}{l}37^{\circ} 2^{\prime} 33.50^{\prime \prime S}, \\
174^{\circ} 51^{\prime} 21.92^{\prime \prime} \mathrm{E}\end{array}$ & $\begin{array}{l}\text { Tidal mud flats } \\
\text { within harbour }\end{array}$ & $\begin{array}{l}\text { Quaternary basalt; } \\
\text { Miocene limestone; } \\
\text { Quaternary } \\
\text { postglacial alluvium }\end{array}$ \\
\hline Pomare & 25 Jan 2009 & $\begin{array}{l}35^{\circ} 16^{\prime} 0.34^{\prime \prime} \mathrm{S} \\
174^{\circ} 7^{\prime} 39.83 " \mathrm{E}\end{array}$ & $\begin{array}{l}\text { Embayed } \\
\text { estuarine mud flat }\end{array}$ & $\begin{array}{l}\text { Triassic-Jurassic } \\
\text { greywacke }\end{array}$ \\
\hline
\end{tabular}




\subsection{Sample Collection}

Sample collection was carried out at low tide, when most A. stutchburyi were not fully submerged. The clams were found buried at a shallow $(<20 \mathrm{~mm})$ depth in the sediment, and could often be identified by a clump of green algae attached to the shell umbo, protruding from the sediment surface. Approximately 20-30 live clams were collected at each location, along with one surface sediment sample (down to $\sim 50 \mathrm{~mm}$ depth), taken from the low tide mark.

Once collected A. stutchburyi were killed by submerging them in freshwater. During this stage organic tissue fell out of the open valves. Shells were subsequently cleaned in water with a toothbrush to remove sediment and residual organic material, air dried, and stored in sample bags prior to more detailed preparation in the laboratory. Sediment was likewise stored in sample bags.

\subsection{Sample preparation}

\subsubsection{A. stutchburyi shells}

In the laboratory, the shells were re-cleaned and dried in the oven for approximately 48 hr at $40^{\circ} \mathrm{C}$. Once dry, the dimensions of shells, with both valves connected were measured. Subsequently, valves of each shell were separated, weighed, and labeled 'a' or ' $b$ ' for the left-side valve and right-side valve respectively, relative to the downward direction of the umbo (Fig 2.1).

Samples were then selected for analysis based on the growth patterns visible on the external shell surface. In particular for the Ligar Bay samples, shells were chosen with an apparent range of growth rates, represented by the distance between macro-bands. Left or right valves were chosen at random. Selected shell valves were cut by with diamond saw following the direction of maximum growth (Figure 2.3). The shell 
cross-sections were subsequently set in epoxy resin in full circle mounts, along with a fragment of NIST-610 glass (Figure 2.4). Once dry, mounts were polished on a $200 \mu \mathrm{m}$ lap to expose the shell and NIST-610 surface to be ablated on the LA-ICP-MS.

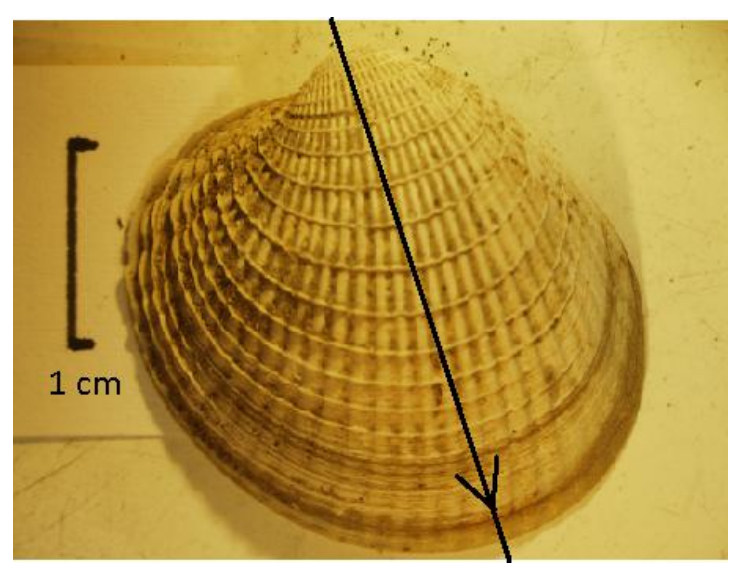

Figure 2.3 A. stutchburyi shell, line and the arrow indicates the maximum direction of growth, down which shells were sectioned with a diamond saw.

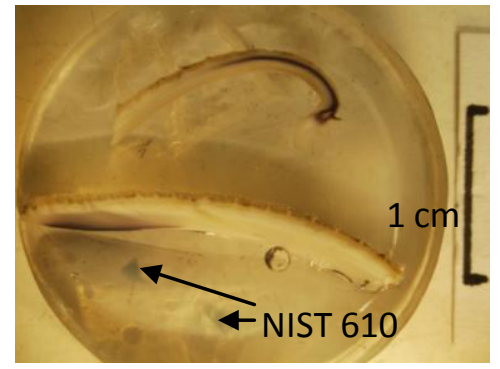

Figure 2.4 A section of A. stutchburyi shell mounted in epoxy, with NIST610 fragments in bottom left section of the mount.

\subsubsection{Sediment}

Before sediment was sent for X-ray fluorescence (XRF) analysis, it was washed to remove soluble salts precipitated from seawater (principally $\mathrm{Na}$ and $\mathrm{Mg}$ ) and dried in an ultra-clean laboratory. For each sample, preparation was as follows: $5 \mathrm{~g}$ of sediment was put into a separate glass beaker, with $40 \mathrm{~mL}$ of ultraclean $(>18.2 \mathrm{M} \Omega$ ) water. Samples were then sonicated for $25 \mathrm{~min}$, and subsequently transferred into centrifuge tubes. The dispersed sediment was centrifuged at $2000 \mathrm{rpm}$ for 10-30 min until all particulate material was concentrated at the bottom of the tube. Liquid was then removed by pipette. This process was repeated for each sample until sediment would not separate from the liquid after centrifuge. Each sediment sample was transferred back into a glass beaker, covered, and dried in an oven at $50^{\circ} \mathrm{C}$ for one week. The samples were then stored in the same beakers until sent for XRF major element analysis at SpectroChem Ltd. 


\subsection{Sample analysis}

\subsubsection{A. stutchburyi shells - LA-ICP-MS trace element analysis}

Analyses of the sectioned A. stutchburyi shells were performed using a New Wave 193 $\mathrm{nm}$ laser ablation system coupled to an Agilent 7500CS ICP-MS system at Victoria University of Wellington. A transect of ablation points, at $100 \mu \mathrm{m}$ and in some cases 50 $\mu \mathrm{m}$ spacing, was made across each shell section through the outer crossed lamellar layer, from the ventral margin edge of the shell, towards the umbo (Fig 2.5). These transects passed through the crossed lamellar layer of the shell, 100-300 $\mu \mathrm{m}$ beneath the periostracum layer. Care was taken to maintain a consistent distance between ablation points and the periostracum, to minimise trace element/Ca $(\mathrm{TE} / \mathrm{Ca})$ variation caused by trace element changes with depth through the shell.

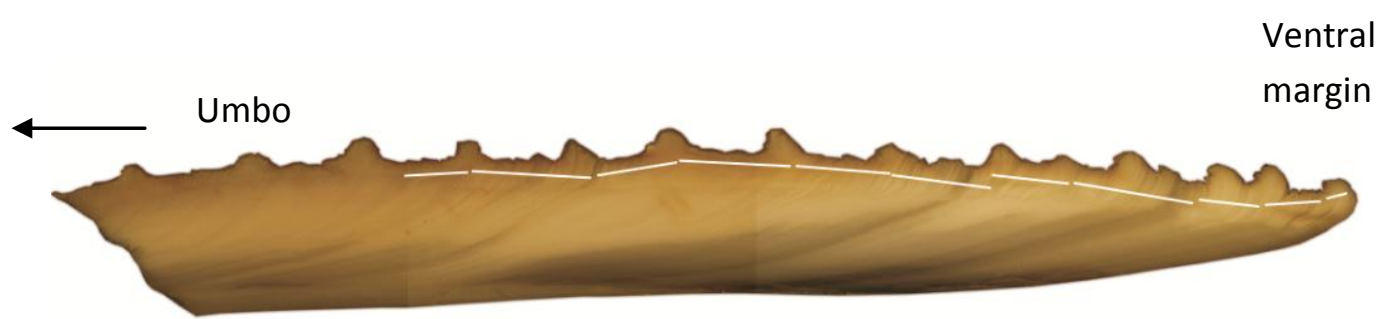

Figure 2.5 Cross section of Ligar Bay 1B, showing approximate path of LAICP-MS transect (white lines). 
Table 2.2 LA-ICP-MS operating parameters

\begin{tabular}{ll}
\hline Laser Ablation & New Wave $193 \mathrm{~nm}$ (deep UV) solid state \\
Laser ablation system & Static spot analyses \\
Ablation mode & $\sim 0.1 \mu \mathrm{m}$ \\
Depth ablated/pulse & \\
ICP-MS & Agilent $7500 \mathrm{CS}$ \\
ICP-MS system & Peak hopping \\
Acquisition mode & Pulse counting \\
Detection mode & $\mathrm{NIST} 610$ \\
Tuning & Rastering $(2 \mu \mathrm{m} / \mathrm{s})$ beneath a $35 \mu \mathrm{m} \mathrm{spot}$ \\
Tuning standard & ${ }^{7} \mathrm{Li},{ }^{11} \mathrm{~B},{ }^{24} \mathrm{Mg},{ }^{27} \mathrm{Al},{ }^{55} \mathrm{Mn},{ }^{63} \mathrm{Cu},{ }^{66} \mathrm{Zn},{ }^{75} \mathrm{As},{ }^{86} \mathrm{Sr},{ }^{88} \mathrm{Sr},{ }^{138} \mathrm{Ba},{ }^{238} \mathrm{U}$ \\
Ablation mode & $0.85 \mathrm{~L} / \mathrm{min}$ \\
Monitored isotopes & $80-90 \%$ \\
Carrier gas (Ar) & $1500 \mathrm{~W}$ \\
Ablation gas (He) & $1.72 \mathrm{~V}$ \\
RF Power & $5 \mathrm{~Hz}$ \\
RF Matching & $55 \%$ \\
Lepetition rate &
\end{tabular}

\section{Standards and calibration}

Calibration standard

NIST-SRM610

Ablation mode

$35 \mu \mathrm{m}$ spot

Repetition rate

$5 \mathrm{~Hz}$

Laser power

$55 \%$

Background acquisition

$60 \mathrm{~s}$

Sample data acquisition

$60 \mathrm{~s}$

Washout time

$90 \mathrm{~s}$

Measured Isotopes

${ }^{7} \mathrm{Li},{ }^{11} \mathrm{~B},{ }^{24} \mathrm{Mg},{ }^{27} \mathrm{Al},{ }^{55} \mathrm{Mn},{ }^{63} \mathrm{Cu},{ }^{66} \mathrm{Zn},{ }^{75} \mathrm{As},{ }^{86} \mathrm{Sr},{ }^{88} \mathrm{Sr},{ }^{138} \mathrm{Ba},{ }^{238} \mathrm{U}$

\section{A. stutchburyi method}

Repetition rate

Ablation mode

Laser power

Background acquisition

Sample data acquisition

Washout time

Measured Isotopes
$5 \mathrm{~Hz}$

$30 \mu \mathrm{m}$ spot

$50 \%$

$60 \mathrm{~s}$

$60 \mathrm{~s}$

$90 \mathrm{~s}$

${ }^{7} \mathrm{Li},{ }^{11} \mathrm{~B},{ }^{24} \mathrm{Mg},{ }^{27} \mathrm{Al},{ }^{55} \mathrm{Mn},{ }^{63} \mathrm{Cu},{ }^{66} \mathrm{Zn},{ }^{75} \mathrm{As},{ }^{86} \mathrm{Sr},{ }^{88} \mathrm{Sr},{ }^{138} \mathrm{Ba},{ }^{238} \mathrm{U}$ 
NIST-610 glass in each mount was ablated to tune the LA-ICP-MS before each run, and was also measured before and after each run, and after every 5-10 ablation points in the shell throughout a run, as an external standard. Data processing was as follows: 1 . Raw elemental counts for each ablation were averaged as well as background elemental counts measured prior to each ablation. 2. The background count averages were subtracted from the ablation element averages. 3. The background-subtracted elemental counts were ratioed to $\mathrm{Ca}$. 4. The elemental/Ca ratios were then normalised using NIST-610 values published by the National Institute of Standards and Technology, which corrected for machine drift and elemental fractionation. 5. Finally, atomic trace element/Ca ratios were converted into units of $\mathrm{mmol} / \mathrm{mol}$.

\subsubsection{Sediment - X-ray fluorescence major element analysis}

Major element analyses were carried out on each sediment sample at SpectraChem Analytical Laboratory in Lower Hutt, Wellington. XRF spectrometry was carried out on $1 \mathrm{~g}$ samples fused to make borate glass discs producing data for major element oxides $\left(\mathrm{SiO}_{2}, \mathrm{Al}_{2} \mathrm{O}_{3}, \mathrm{Fe}_{2} \mathrm{O}_{3}, \mathrm{CaO}, \mathrm{MgO}, \mathrm{SO}_{3}, \mathrm{~K}_{2} \mathrm{O}, \mathrm{Na}_{2} \mathrm{O}, \mathrm{MnO}, \mathrm{TiO}_{2}\right.$ and $\left.\mathrm{P}_{2} \mathrm{O}_{5}\right)$.

\subsection{Analytical uncertainty in LA-ICP-MS analyses}

Analytical uncertainty on the LA-ICP-MS analyses was monitored in two ways. Firstly, during tuning the percent relative standard deviation (RSD) for all elements were calculated. For each analysis carried out, all elements had RSD percentages ranging between 2-8\%. Secondly, for the Kaiaua, Pomare and Manakua A. stutchburyi shells, LA-ICP-MS horizontal transects (parallel to the maximum direction of growth) were repeated on separate days. In these repeats, laser ablation points were made adjacent to the original laser ablation points, in the direction of maximum growth (i.e. new laser ablation points were made in between existing laser ablation points). Graphical comparison of the original and repeat runs for the Kaiaua shell (Figure 2.6) show 
excellent reproducibility for $\mathrm{Mg} / \mathrm{Ca}, \mathrm{Mn} / \mathrm{Ca}, \mathrm{Ba} / \mathrm{Ca}$ and $\mathrm{U} / \mathrm{Ca}$ ratios; moderate reproducibility for $\mathrm{B} / \mathrm{Ca}$ and $\mathrm{As} / \mathrm{Ca}$ ratios; and relatively poor reproducibility for $\mathrm{Al} / \mathrm{Ca}$, $\mathrm{Li} / \mathrm{Ca}, \mathrm{Cu} / \mathrm{Ca}$ and $\mathrm{Zn} / \mathrm{Ca}$ ratios. The results for the Kaiaua shell are representative of the Pomare and Mankau shells.

Differences in the average $\mathrm{TE} / \mathrm{Ca}$ ratios between original and repeat laser-ablation runs were calculated for all three shells (Table 2.3). The percentage of variation between average $\mathrm{TE} / \mathrm{Ca}$ ratios, in respect of the average $\mathrm{TE} / \mathrm{Ca}$ ratios for those shells, is also reported. It should be noted that some of the variation between the adjacent points is due to real horizontal variation in shell chemistry; so that analytical variance is likely overestimated. These results agree with the visual comparisons (on the next page) - the differences between repeat and original average TE/Ca ratios account for small percentages of average $\mathrm{Mg} / \mathrm{Ca}, \mathrm{Mn} / \mathrm{Ca}, \mathrm{U} / \mathrm{Ca}$ and $\mathrm{Ba} / \mathrm{Ca}$ shell ratios, but larger percentages of average $\mathrm{Al} / \mathrm{Ca}$ and $\mathrm{Zn} / \mathrm{Ca}$ shell ratios. Overall, the comparison of runs completed on completely separate days, demonstrates reproducibility especially for $\mathrm{Mg} / \mathrm{Ca}, \mathrm{Mn} / \mathrm{Ca}, \mathrm{U} / \mathrm{Ca}$ and $\mathrm{Mn} / \mathrm{Ca}$.

Table 2.3 The difference in average TE/Ca ratios between original and repeat transects in Kaiaua, Pomare and Manakau shells. Average TE/Ca ratios for each shell. The percentage of the average TE/Ca ratios the difference between averages represent (difference between averages $\div$ average TE/Ca x 100) highlighted in grey.

\begin{tabular}{|l|l|l|l|l|l|l|l|l|l|l|l|}
\hline Shell & & $\mathrm{Li} / \mathrm{Ca}$ & $\mathrm{B} / \mathrm{Ca}$ & $\mathrm{Mg} / \mathrm{Ca}$ & $\mathrm{Al} / \mathrm{Ca}$ & $\mathrm{Mn} / \mathrm{Ca}$ & $\mathrm{Cu} / \mathrm{Ca}$ & $\mathrm{Zn} / \mathrm{Ca}$ & $\mathrm{As} / \mathrm{Ca}$ & $\mathrm{Ba} / \mathrm{Ca}$ & $\mathrm{U} / \mathrm{Ca}$ \\
\hline Kaiaua & $\begin{array}{l}\text { Average } \\
\text { shell }\end{array}$ & 0.0085 & 0.074 & 0.76 & 0.0023 & 0.11 & 0.0014 & 0.00076 & 0.0011 & 0.0068 & 0.00031 \\
\hline & Difference & 0.0013 & 0.0043 & 0.00057 & 0.00089 & 0.0023 & 0.00012 & 0.00042 & 0.00012 & 0.00015 & 0.000016 \\
\hline & Percentage & 15 & 5.8 & 0.075 & 39 & 2 & 8.7 & 55 & 11 & 2.2 & 5.3 \\
\hline Pomare & $\begin{array}{l}\text { Average } \\
\text { shell }\end{array}$ & 0.0083 & 0.062 & 1.04 & 0.0058 & 0.028 & 0.0018 & 0.00052 & 0.0017 & 0.0052 & 0.00022 \\
\hline & Difference & 0.00037 & 0.0011 & 0.017 & 0.0017 & 0.00016 & 0.00016 & 0.00027 & 0.00016 & 0.000025 & 0.0000052 \\
\hline & Percentage & 4.4 & 1.7 & 1.6 & 29 & 0.55 & 9 & 51 & 9.4 & 0.49 & 2.4 \\
\hline Manakau & $\begin{array}{l}\text { Average } \\
\text { shell }\end{array}$ & 0.0079 & 0.085 & 0.97 & 0.0025 & 0.15 & 0.001 & 0.00049 & 0.00056 & 0.0048 & $3.20 \mathrm{E}-04$ \\
\hline & Difference & 0.00093 & 0.00058 & 0.012 & 0.0042 & 0.012 & 0.000041 & 0.000019 & 0.000047 & 0.0001 & 0.000024 \\
\hline & Percentage & 12 & 0.69 & 1.2 & 173 & 8.3 & 4.1 & 4 & 8.4 & 2.1 & 7.6 \\
\hline
\end{tabular}



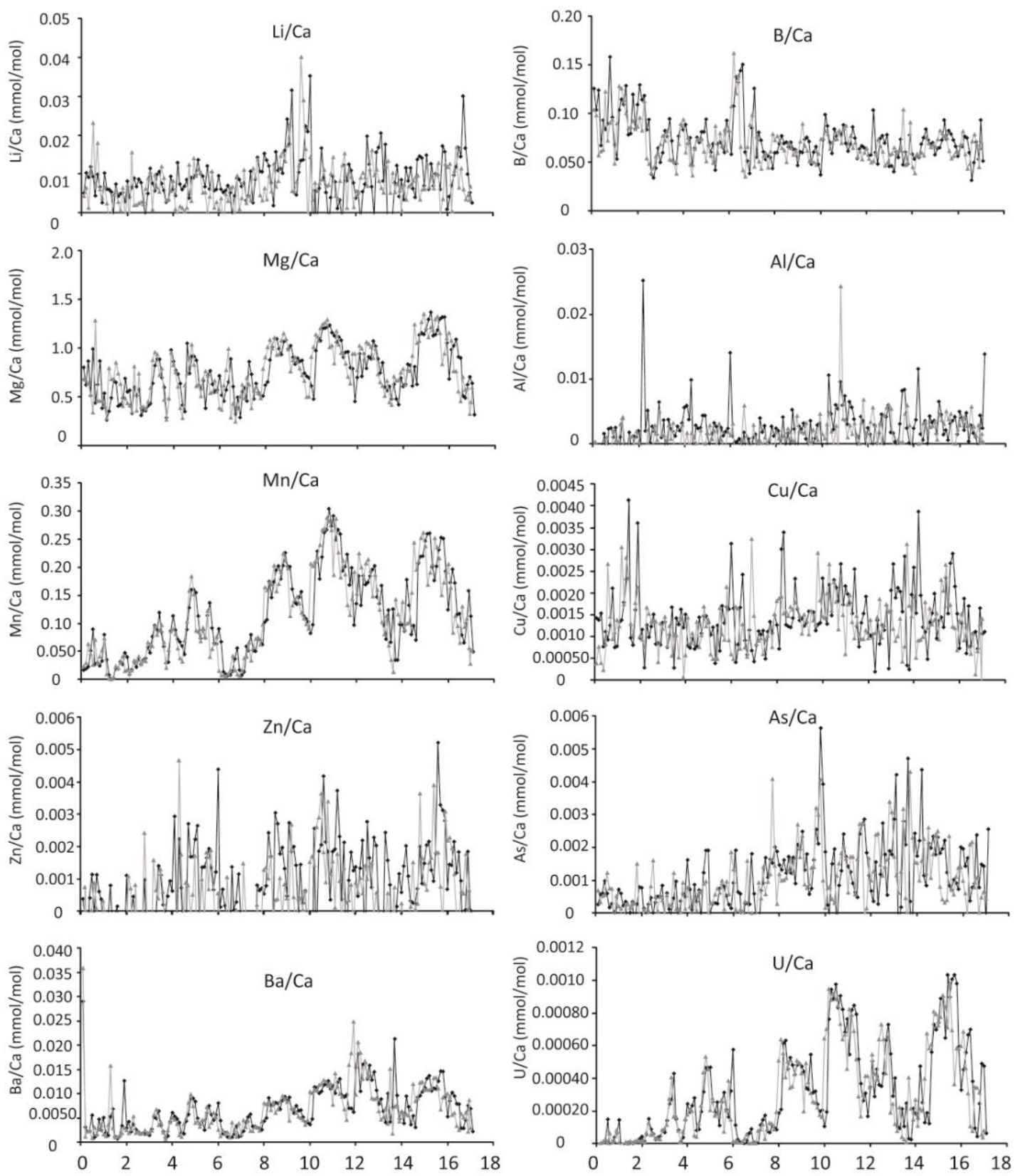

Figure 2.6 TE/Ca ratios for the Kaiaua original and repeat transects, plotted against distance from the ventral margin in mm (horizontal axis). Black lines and markers are the original run. Grey lines and markers are the repeat run. 


\subsection{RESULTS}

\subsection{A. stutchburyi trace element chemistry}

\subsubsection{Transects through the shell}

Before making transects across the shell surface, parallel to maximum growth direction, in A. stutchburyi shells, heterogeneity vertically along a growth band through the shells was assessed. This was done by making four transects that followed growth lines in the Ligar Estaury, Ligar Bay 6B and Raglan shells. These passed through the outer crossedlamellar layer of shell, and (in some cases) into the middle homogeneous layer (see figure 3.1 below).

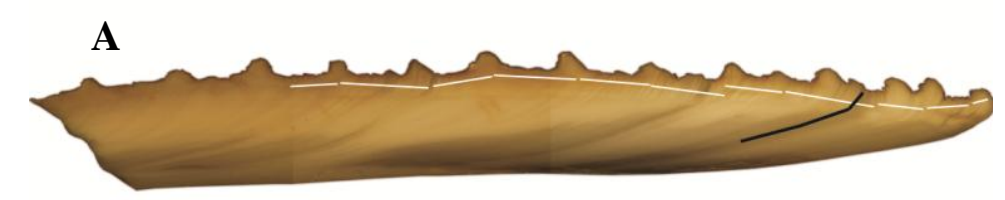

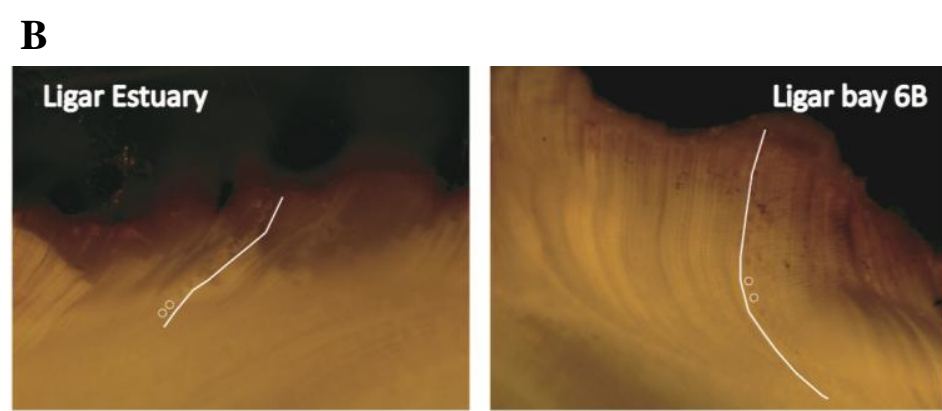

Raglan

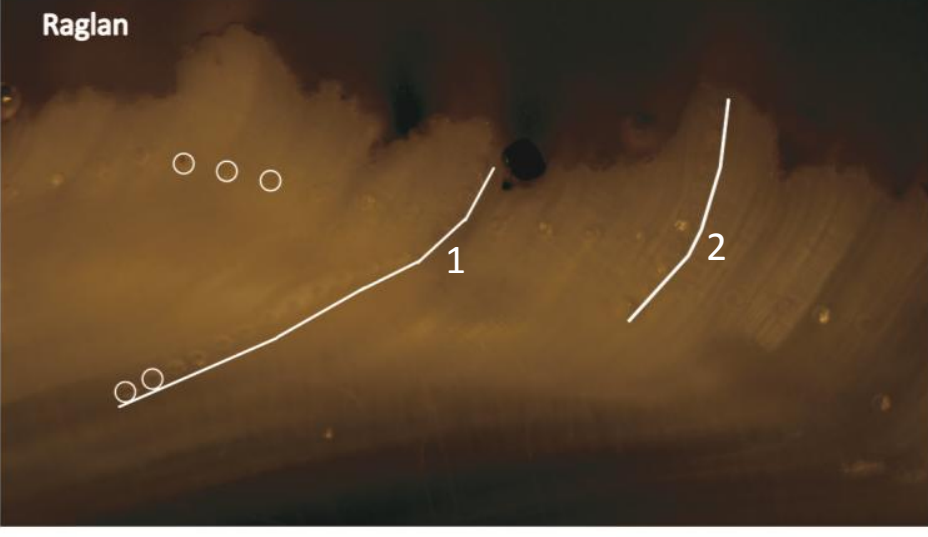

Figure 3.1 A. Example of laser ablation transects made on A. stutchburyi shells. White lines represent transects made parallel to maximum growth direction. Black line represents transects parallel to growth lines (a 'transect through shell').

B. Photographs of laserablation transects down growth lines in Ligar Estuary, Ligar Bay 6B and Raglan A. stutchburyi shells. White lines show the laser ablation transects. Scale: each laser-ablation point is $35 \mu \mathrm{m}$ in diameter (white circles highlight some of these points). 

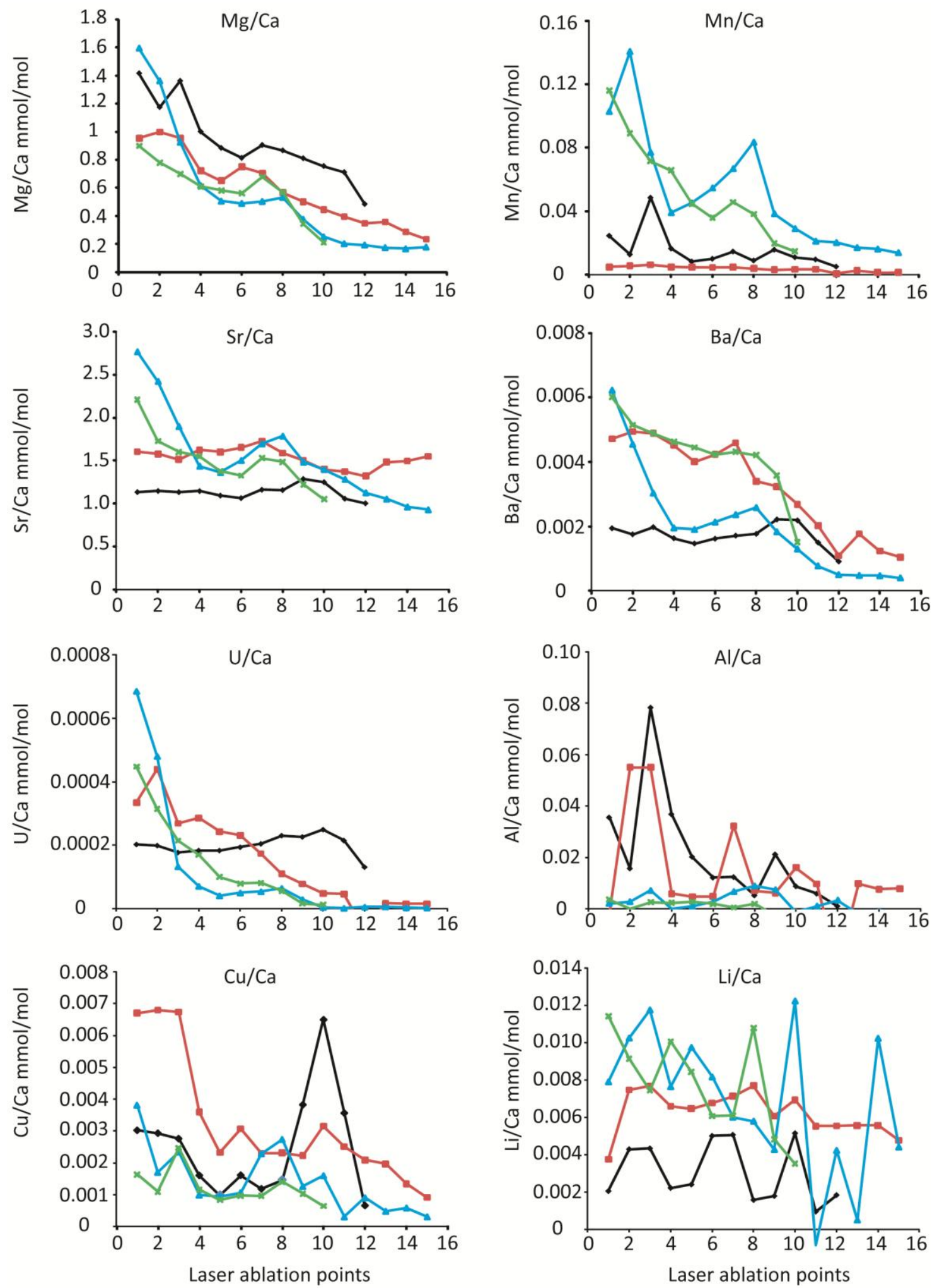

$\longrightarrow$ - Ligar Estuary Figure 3.2 Mg/Ca, $\mathrm{Mn} / \mathrm{Ca}, \mathrm{Sr} / \mathrm{Ca}, \mathrm{U} / \mathrm{Ca}, \mathrm{Ba} / \mathrm{Ca} \mathrm{Al} / \mathrm{Ca}, \mathrm{Cu} / \mathrm{Ca}$ and $\mathrm{Li} / \mathrm{Ca}$ -Ligar Bay 6B cross-section transects. Combined graphs of four cross-sections through three shells. Point ' 1 ' on the horizontal axis is the first laser ablation point -

$\longrightarrow$ Raglan1 at the top of the growth line, point ' 16 ' is the laser point furthest through the

$\rightarrow$ Raglan2 shell. Laser ablation points were $35 \mu \mathrm{m}$ and at approximately $50 \mu \mathrm{m}$ spacing. 

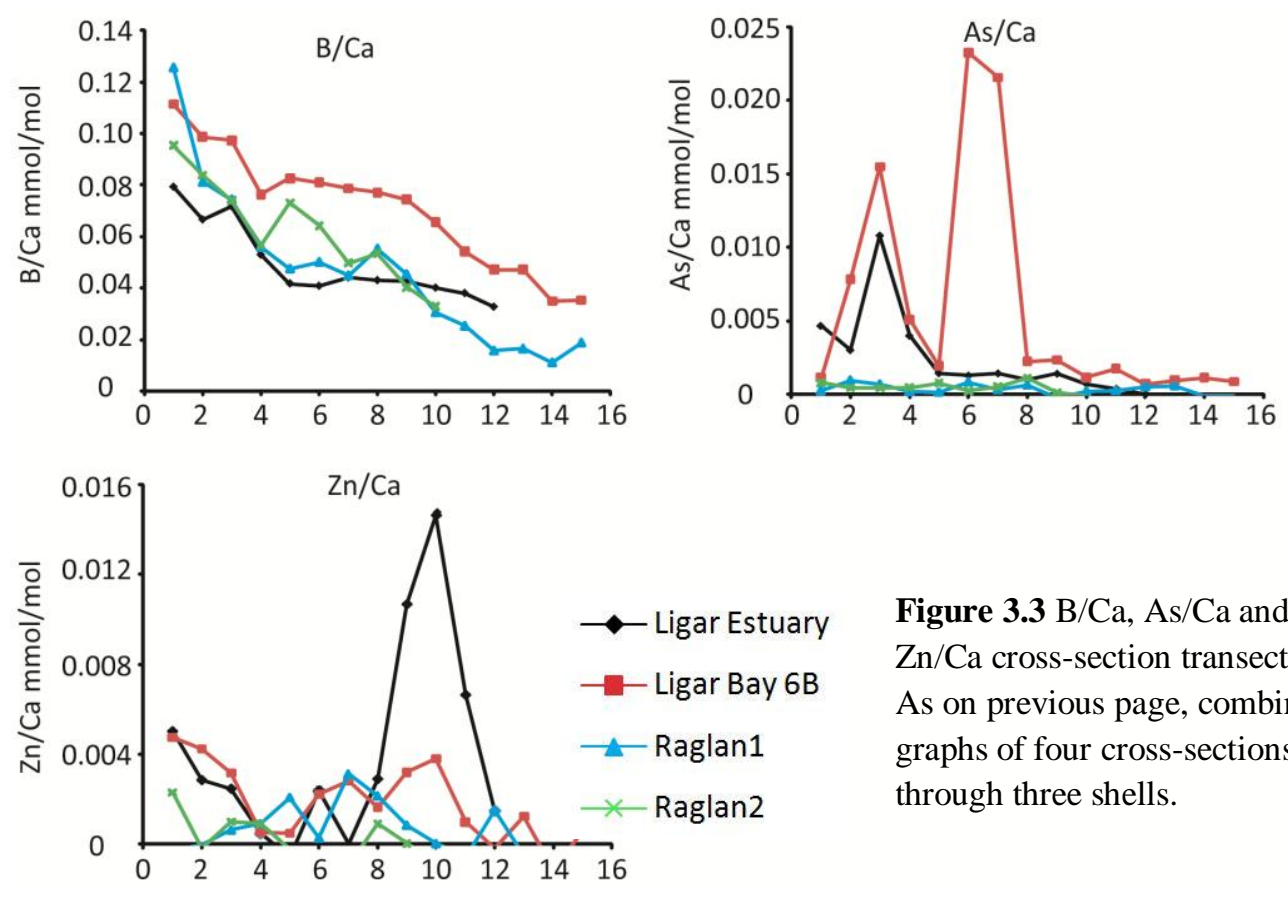

Figure 3.3 $\mathrm{B} / \mathrm{Ca}$, As/Ca and $\mathrm{Zn} / \mathrm{Ca}$ cross-section transects. As on previous page, combined graphs of four cross-sections through three shells.

The most dominant trend in the data from the transects through the shell was the progressive decrease in TE/Ca ratios down the growth lines (i.e. with increased depth into the shell). A linear decrease with a high degree of correlation was observed for $\mathrm{Mg} / \mathrm{Ca}, \mathrm{Mn} / \mathrm{Ca}, \mathrm{Ba} / \mathrm{Ca}$ and $\mathrm{B} / \mathrm{Ca}$ ratios. Over $450 \mu \mathrm{m}$ distance down a growth line the decrease of $\mathrm{Mg} / \mathrm{Ca}$ ratios varied between $1.4-0.6 \mathrm{mmol} / \mathrm{mol}$; for $\mathrm{Mn} / \mathrm{Ca}$ ratios between 0.11-0.038 $\mathrm{mmol} / \mathrm{mol}$, for $\mathrm{B} / \mathrm{Ca}$ ratios between $0.097-0.04 \mathrm{mmol} / \mathrm{mol}$; for $\mathrm{Ba} / \mathrm{Ca}$ between $0.0049-0.0020 \mathrm{mmol} / \mathrm{mol}$; for $\mathrm{Sr} / \mathrm{Ca}$ ratios between $1.4-1.2 \mathrm{mmol} / \mathrm{mol}$; and for $\mathrm{U} / \mathrm{Ca}$ ratios between $0.00070-0.00034 \mathrm{mmol} / \mathrm{mol}$. There were exceptions: $\mathrm{Mn} / \mathrm{Ca}$ in Ligar Estuary had one anomalous $\mathrm{Mn} / \mathrm{Ca}$ peak; $\mathrm{Sr} / \mathrm{Ca}$ ratios showed a linear decrease in the Raglan shell cross sections, but in the Ligar Bay 6B and Ligar Estuary cross sections $\mathrm{Sr} / \mathrm{Ca}$ ratios remained constant. Similarly, U/Ca ratios decreased linearly in all crosssections except for the Ligar Estuary shell. Other TE/Ca ratios $(\mathrm{Li} / \mathrm{Ca}, \mathrm{Al} / \mathrm{Ca}, \mathrm{Cu} / \mathrm{Ca}$ and As/Ca) generally showed an overall decrease through the shell, but were punctuated by large variations between points. This likely due to the larger analytical uncertainty involved in measuring these low concentration elements (Chapter 2). 
For the TE/Ca ratios that did follow a linear trend, the rate of decrease was comparable between the two cross sections taken down different growth lines on the same shell from Raglan - with $\mathrm{Mg} / \mathrm{Ca}, \mathrm{Sr} / \mathrm{Ca}, \mathrm{Ba} / \mathrm{Ca}, \mathrm{U} / \mathrm{Ca} \mathrm{Mn} / \mathrm{Ca}$ and $\mathrm{B} / \mathrm{Ca}$ ratios having similar gradients (e.g. -0.59 and -0.86 for $\mathrm{Mg} / \mathrm{Ca}$ ). However, in these Raglan cross-sections the TE/Ca ratios were not individually comparable - the first cross section decreased from typically higher TE/Ca ratios (e.g. $\mathrm{Mg} / \mathrm{Ca}$, Fig 3.2), most likely as the cross sections were made through growth lines at different distances horizontally on the shell. Between shells the rate of decrease appeared to vary significantly, as the gradients were quite different (see Figures 3.2 and 3.3). There was strong co-variation between $\mathrm{Mg} / \mathrm{Ca}$, $\mathrm{Sr} / \mathrm{Ca}, \mathrm{Ba} / \mathrm{Ca}, \mathrm{U} / \mathrm{Ca}, \mathrm{Mn} / \mathrm{Ca}$ and $\mathrm{B} / \mathrm{Ca}$ ratios in each shell cross-section. In particular, in the first Raglan cross-section, there is a peak in each of these TE/Ca ratios at point eight against the general decrease in ratios, which also coincides with major peak in $\mathrm{Al} / \mathrm{Ca}$.

\subsubsection{Trace element/Ca transects}

A series of TE/Ca ratios for each of the eleven shell samples were measured by LAICP-MS transects across the shells, beginning at the ventral margin of each shell and running towards the umbo (white lines on Figure 3.1). The distance of each transect varied, comprising between 160 and 406 individual laser ablation measurements to allow for comparison between shells of varying age. Transect data was plotted against distance from the ventral margin (in $\mathrm{mm}$ ). This means that in the dataset plotted in Figures 3.4-3.25, chronological time runs right to left, and ontogenetic age of the clam is progressively younger from left to right, and progressively older from right to left. 


\subsubsection{Key trends and differences between the Ligar Bay and Ligar Estuary shells}

$\mathrm{Mg} / \mathrm{Ca}$

The range in $\mathrm{Mg} / \mathrm{Ca}$ ratios between the Ligar Bay shells was significant. The Ligar Bay 4B and Ligar Bay 6B Mg/Ca records were both within a narrow and low range, with ratios between $0.28-2.6 \mathrm{mmol} / \mathrm{mol}$ and $0.14-2.2 \mathrm{mmol} / \mathrm{mol}$ respectively (Figure 3.4). The Ligar Estuary shell contained the widest range $(0.21-1.99 \mathrm{mmol} / \mathrm{mol})$, followed by Ligar Bay 3B (0.42-4.0 mmol/mol). The difference between the highest Ligar Bay 3B ratio and the highest Ligar Bay $6 \mathrm{~B}$ ratio equated to $1.9 \mathrm{mmol} / \mathrm{mol}$. Ligar $1 \mathrm{~B}$ had a comparable range to the Ligar Estuary shell, with $\mathrm{Mg} / \mathrm{Ca}$ ratios varying between $0.4-3.9$ $\mathrm{mmol} / \mathrm{mol}$. The ratio variations throughout the individual records were also quite different. The Ligar Bay 1B and Ligar Estuary records contained large variations that formed peak-trough patterns (up to $2.5 \mathrm{mmol} / \mathrm{mol}$ from peak to trough), compared to the relatively flat $\mathrm{Mg} / \mathrm{Ca}$ record, with small variations $(0.5-1.0 \mathrm{mmol} / \mathrm{mol})$ from the Ligar Bay 4B shell. None of the records appeared to follow the same form, or contain the same variations, as any of the others.

$\mathrm{Sr} / \mathrm{Ca}$

$\mathrm{Sr} / \mathrm{Ca}$ ratio ranges were similar in the Ligar Bay and Ligar Estuary shells, with the Ligar Bay $6 \mathrm{~B}$ shell having the widest range of ratios between 1.0-3.5 mmol/mol (Figure 3.5). Ligar Bay 1B had $\mathrm{Sr} / \mathrm{Ca}$ ratios between 1.0-3.0 mmol/mol, whereas Ligar Bay 4B ranged between 1.0-3.2 mmol/mol, Ligar Bay 3B had $\mathrm{Sr} / \mathrm{Ca}$ ratios ranging between 0.98-2.6 mmol/mol, and Ligar Estuary ranged between 1.3-3.2 $\mathrm{mmol} / \mathrm{mol}$ (although $\mathrm{Sr} / \mathrm{Ca}$ ratios were only available for the oldest half of the shell). The magnitude of the $\mathrm{Sr} / \mathrm{Ca}$ ratio variations throughout the records were also quite comparable between the individuals, with the highest variations in all shells being up to $1.5 \mathrm{mmol} / \mathrm{mol}$, except 
for Ligar 3B, which had variations mostly $<0.5 \mathrm{mmol} / \mathrm{mol}$. There were no specific variations that could be correlated between records.

\section{$\mathrm{Mn} / \mathrm{Ca}$}

All four Ligar Bay Mn/Ca records contained ratios within a similar range: Ligar Bay 1B had ratios between 0.00-0.011 mmol/mol; Ligar Bay 3B between 0.00-0.010 mmol/mol; Ligar Bay 6B between 0.00-0.011 mmol/mol; and Ligar Bay 4B had ratios in the narrowest range, between 0.00-0.007 mmol/mol (Figure 3.6). However, $\mathrm{Mn} / \mathrm{Ca}$ ratios in the Ligar Estuary record were up to an order of magnitude higher than the Ligar Bay records, falling in a very wide range between 0.00-0.57 mmol/mol. The Ligar Estuary record contained 7 sharp $\mathrm{Mn} / \mathrm{Ca}$ peaks (between $0.086-0.37 \mathrm{mmol} / \mathrm{mol}$ ). Although of a lower magnitude, there were at least 3 sharp peaks (between $0.0043-0.011 \mathrm{mmol} / \mathrm{mol}$ ) that interrupted the Ligar Bay 1B record, and 2 peaks (between $0.0048-0.011 \mathrm{mmol} / \mathrm{mol}$ ) in the Ligar Bay $6 \mathrm{~B}$ record.

\section{$\mathrm{Ba} / \mathrm{Ca}$}

$\mathrm{Ba} / \mathrm{Ca}$ ratios were comparable for the Ligar Estuary $(0.0007-0.0084 \mathrm{mmol} / \mathrm{mol})$ and Ligar 6B (0.0004-0.012 mmol/mol) shells (Figure 3.7). Ligar Bay 1B Ba/Ca ratios fell within a slightly wider range of $0.0005-0.017 \mathrm{mmol} / \mathrm{mol}$. Most noticeably, the range in ratios for the Ligar Bay $3 \mathrm{~B}$ and Ligar Bay $4 \mathrm{~B} \mathrm{Ba} / \mathrm{Ca}$ records was an order of magnitude higher than for the other Ligar Bays records, with $\mathrm{Ba} / \mathrm{Ca}$ ratios between 0.0003-0.039 $\mathrm{mmol} / \mathrm{mol}$ and $0.0004-0.046 \mathrm{mmol} / \mathrm{mol}$ respectively. Within these two records there were matching 3-point peaks in $\mathrm{Ba} / \mathrm{Ca}$ of similar amplitude - the highest ratio in the peaks being $0.046 \mathrm{mmol} / \mathrm{mol}$ and $0.039 \mathrm{mmol} / \mathrm{mol}$ for Ligar Bay 4B and Ligar Bay 3B, respectively (marked by red circles on Figure 3.7). However, in the Ligar Bay 4B shell the 3-point peak began at $11 \mathrm{~mm}$ from the ventral margin, and was stretched out over a longer section of shell, to $15 \mathrm{~mm}$ from the ventral margin. It is also possible that a 
small peak found at $3 \mathrm{~mm}$ distance from the ventral margin in the Ligar Bay 4B shell, could be correlated to a similar peak found at $2 \mathrm{~mm}$ from the ventral margin in the Ligar Bay 3B Ba/Ca record (marked with red circles on Figured 3.7). Peaks $(>0.008$ $\mathrm{mmol} / \mathrm{mol}$ ) in the other Ligar Bay and Estuary $\mathrm{Ba} / \mathrm{Ca}$ records (marked with green circles on Figured 3.7) could potentially be correlated to the same event, but as they are not clearly related (in amplitude or shape), these need to be put on the same timescale to test this.

\section{$U / C a$}

There was a clear distinction between Ligar Bay 3B and Ligar Bay 4B, which had U/Ca ratios between $0.0000-0.0004 \mathrm{mmol} / \mathrm{mol}$ and $0.0000-0.0005 \mathrm{mmol} / \mathrm{mol}$, respectively, and Ligar Bay 6B and Ligar Estuary, which had ratios almost twice as high, between 0.0000-0.0008 mmol/mol and 0.0000-0.0008 mmol/mol, respectively (Figure 3.8). The latter two $\mathrm{U} / \mathrm{Ca}$ records contained much greater variations in ratios (up to 0.0008 $\mathrm{mmol} / \mathrm{mol})$, whereas the former two records had small variations $(<0.0002 \mathrm{mmol} / \mathrm{mol})$. No U/Ca record was available for Ligar Bay $1 \mathrm{~B}$ because $\mathrm{U}$ was not analysed in this shell.

\section{$\mathrm{Cu} / \mathrm{Ca}$}

The $\mathrm{Cu} / \mathrm{Ca}$ records were within similar ranges, except for Ligar Bay $4 \mathrm{~B}$, which had ratios an order of magnitude lower than the other three shells (varying between 0.0001$0.0021 \mathrm{mmol} / \mathrm{mol})$. Ligar Bay 3B contained the highest $\mathrm{Cu} / \mathrm{Ca}$ ratios, with a sharp peak of $0.060 \mathrm{mmol} / \mathrm{mol}$ in the middle of the record (Figure 3.9). Peaks were also observed in the Ligar Bay 6B and Ligar Estuary shells, and these were $0.02 \mathrm{mmol} / \mathrm{mol}$ and $\sim 0.04$ $\mathrm{mmol} / \mathrm{mol}$ in size respectively. 

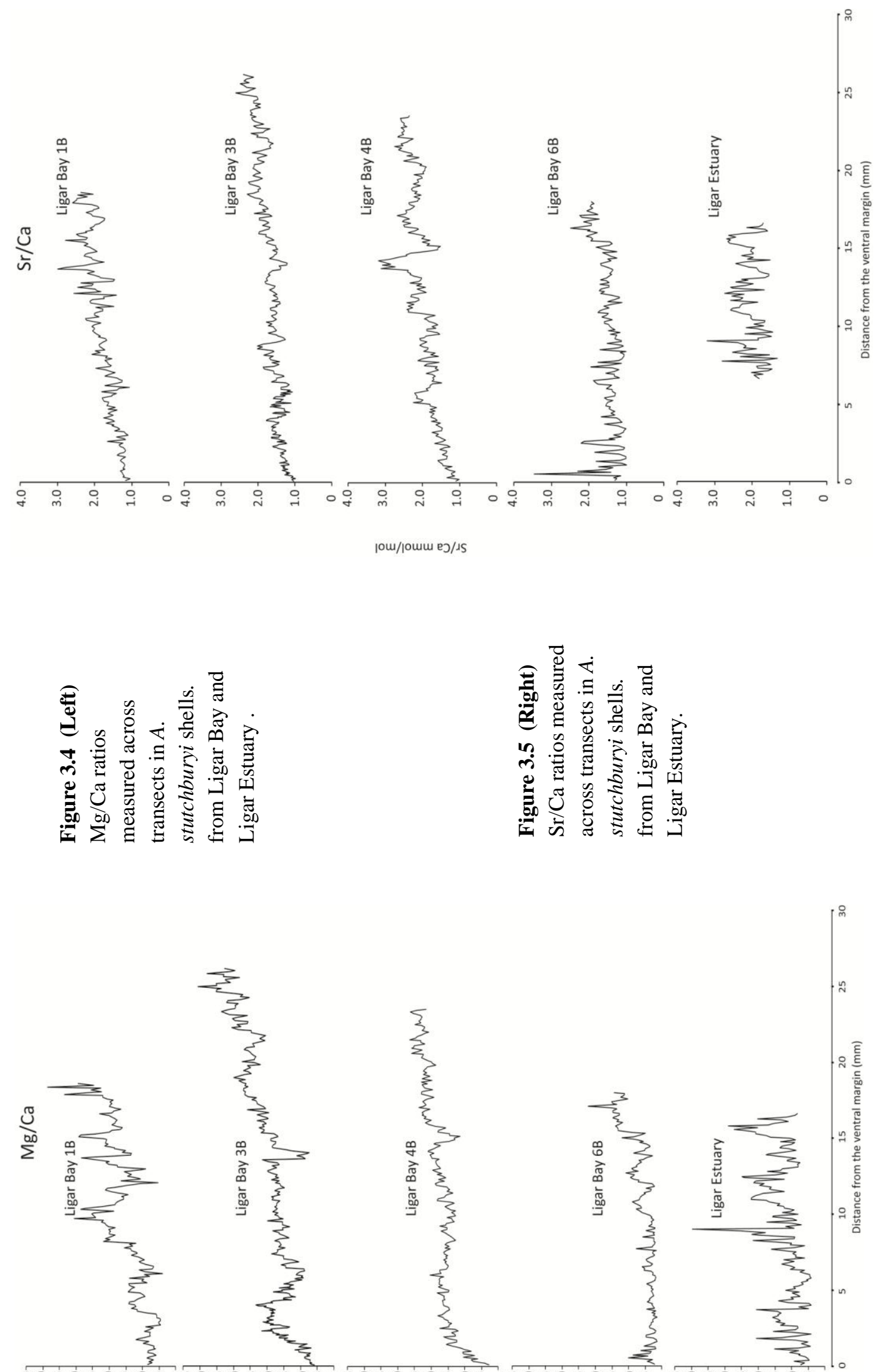

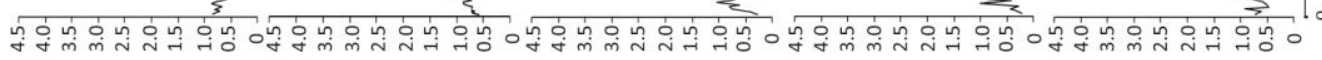



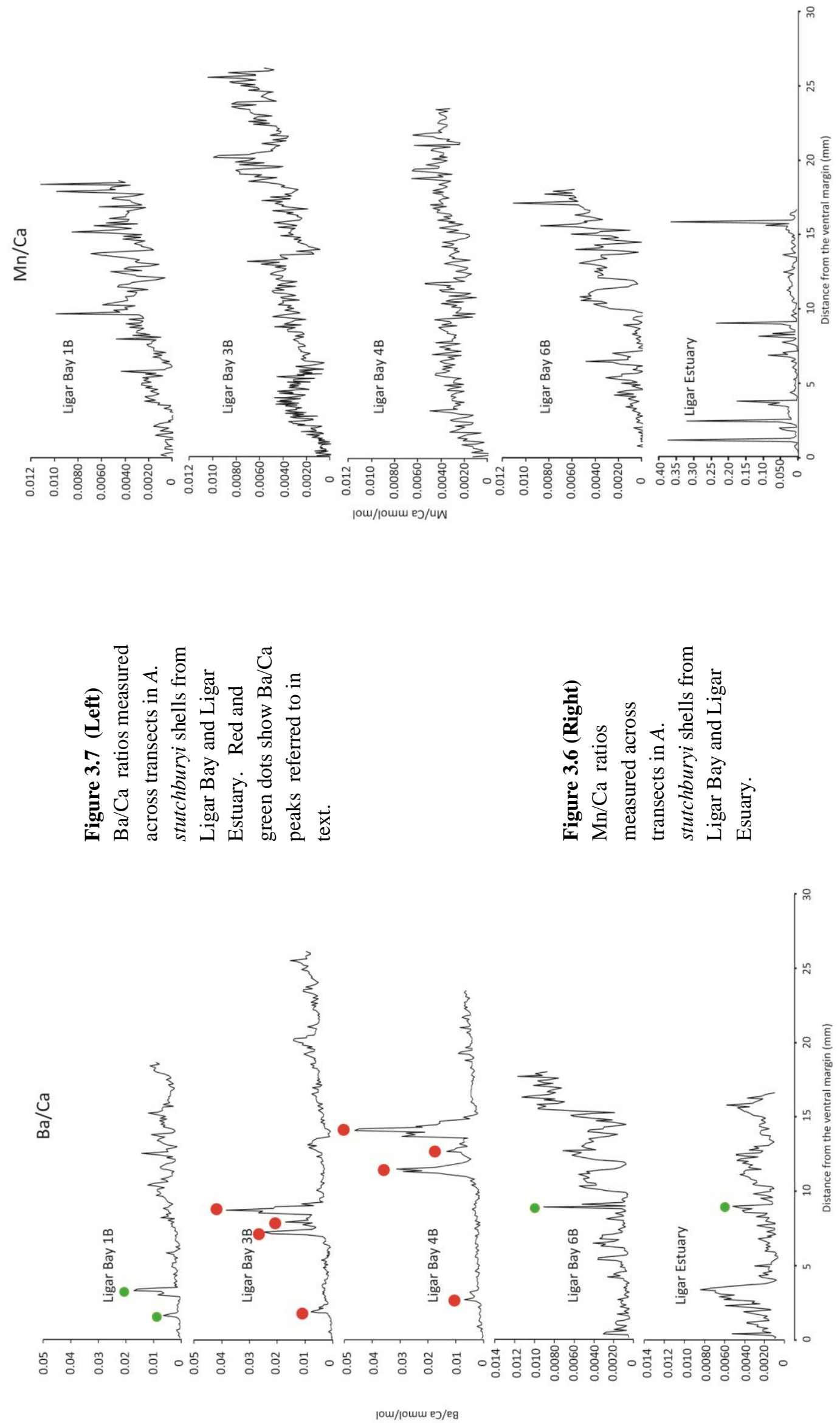

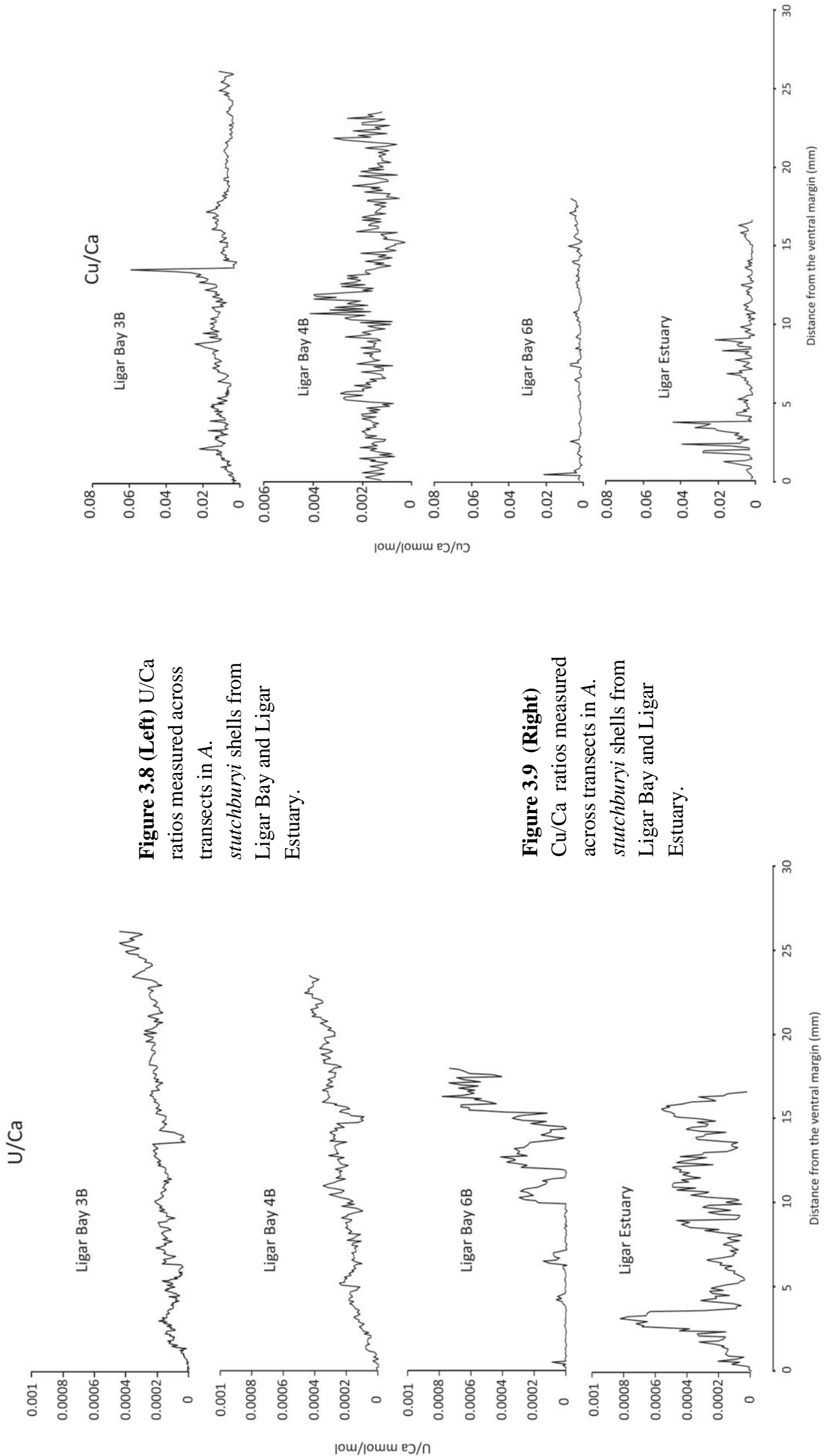


\section{$\mathrm{Zn} / \mathrm{Ca}$}

Ligar Bay 3B and Ligar Bay 4B had similar $\mathrm{Zn} / \mathrm{Ca}$ records, with ratios ranging between 0.000-0.011 $\mathrm{mmol} / \mathrm{mol}$ for each shell, and only small variations $(<0.008 \mathrm{mmol} / \mathrm{mol})$. The Ligar Bay 1B, Ligar Bay 6B and Ligar Estuary records all had a higher range of ratios, between $0.000-0.026 \mathrm{mmol} / \mathrm{mol}, \quad 0.000-0.019 \mathrm{mmol} / \mathrm{mol}$, and $0.000-0.020$ $\mathrm{mmol} / \mathrm{mol}$, respectively (Figure 3.10). There were greater variations in these records ( $>0.01 \mathrm{mmol} / \mathrm{mol})$, especially throughout the Ligar Estuary record, and the latter halves of the Ligar Bay 1B and Ligar Bay 6B records.

\section{$\mathrm{As} / \mathrm{Ca}$}

Ligar Bay 3B, Ligar Bay 4B and Ligar Estuary As/Ca records had ratios within a similar range, between $0.000-0.021 \mathrm{mmol} / \mathrm{mol}, 0.000-0.015 \mathrm{mmol} / \mathrm{mol}$ and $0.000-0.048$ mmol/mol, respectively (Figure 3.11). The Ligar Bay 6B record would have been in a similar range but for three large peaks in As/Ca; the highest of these was at $14 \mathrm{~mm}$ from the ventral margin and was $0.055 \mathrm{mmol} / \mathrm{mol}$. One noticeable feature for three of the Ligar Bay shells $-3 \mathrm{~B}, 4 \mathrm{~B}$ and $6 \mathrm{~B}$ - was the decrease in ratios in the latter stage of all three of these clams' lives (starting between 5-10 $\mathrm{mm}$ from the ventral margin until 0 $\mathrm{mm}$ ). This is not an analytical effect as full transects of the three individual shells were analysed in the same analytical session, but each shell on different days, over several months.

$\mathrm{Li} / \mathrm{Ca}$

The Li/Ca records for Ligar Bay 3B, Ligar Bay 4B and Ligar Estuary had ratios within similar ranges; between $0.00-0.027 \mathrm{mmol} / \mathrm{mol}, 0.00-0.041 \mathrm{mmol} / \mathrm{mol}$ and $0.00-0.040$ 
$\mathrm{mmol} / \mathrm{mol}$, respectively (Figure 3.12). There were no clear temporal trends in any of the records. Li was not measured in the Ligar Bay 1B and Ligar Bay 6B shells.

$\mathrm{B} / \mathrm{Ca}$

The Ligar Bay 3B and Ligar Bay 4B B/Ca records were both within relatively narrow ranges $(\mathrm{B} / \mathrm{Ca}$ between $0.053-0.13 \mathrm{mmol} / \mathrm{mol}$ and $0.033-0.11 \mathrm{mmol} / \mathrm{mol}$, respectively) compared to the Ligar Estuary record, which ranged between $0.053-0.32 \mathrm{mmol} / \mathrm{mol}$ (Figure 3.13). The latter record also contained a number of sharp increases - up to 0.21 $\mathrm{mmol} / \mathrm{mol}$ at a time. There also appeared to be no clear temporal trends in any of the records. B was not measured in the Ligar Bay 1B and Ligar Bay 6B shells.

$\mathrm{Al} / \mathrm{Ca}$

The Ligar Estuary $\mathrm{Al} / \mathrm{Ca}$ record contained a number a sharp peaks (up to 0.41 $\mathrm{mmol} / \mathrm{mol}$ ) throughout it (Figure 3.14). The latter half of the Ligar Bay 1B record also contained these peaks, with a similar peak of $0.41 \mathrm{mmol} / \mathrm{mol}$ at $14.7 \mathrm{~mm}$ from the ventral margin. The records of the remaining shells predominantly consisted of smaller variations $(<0.05 \mathrm{mmol} / \mathrm{mol})$, although in the Ligar Bay 3B and Ligar Bay 6B shells there were greater variations and higher ratios in the oldest sections of their records (i.e. the sections furthest away from the ventral margin). 

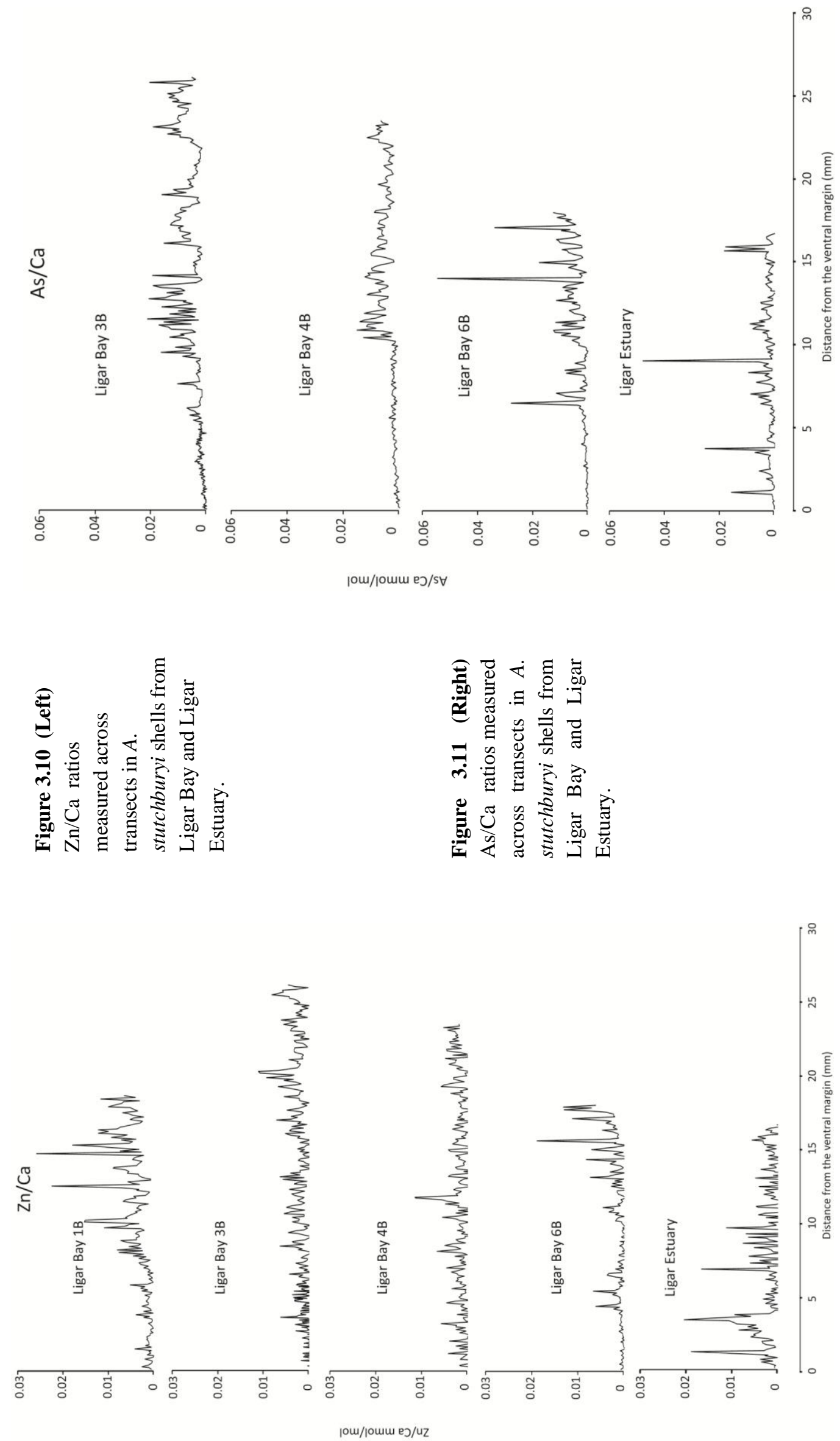

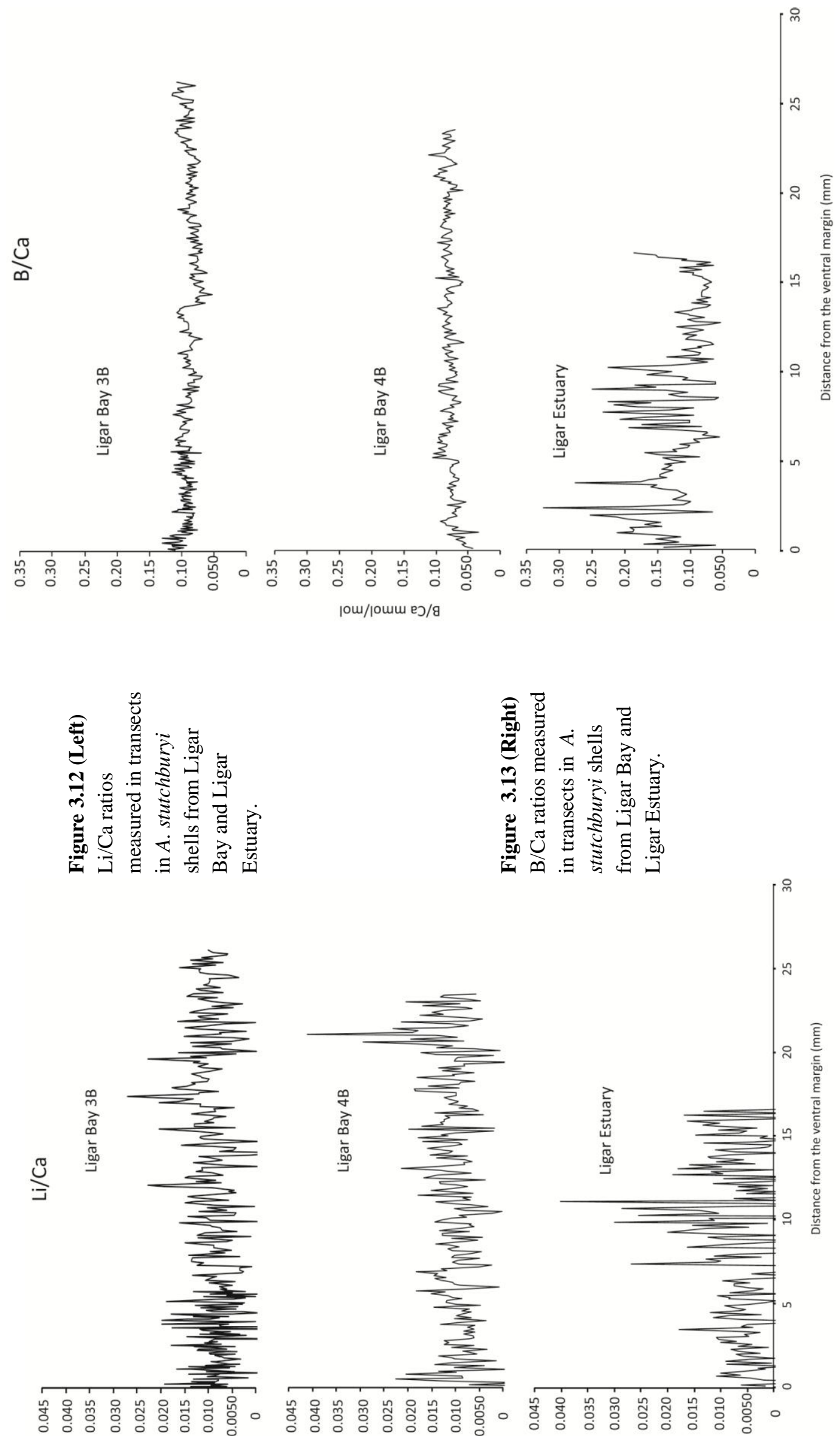

fom/lomm eJ/!7 


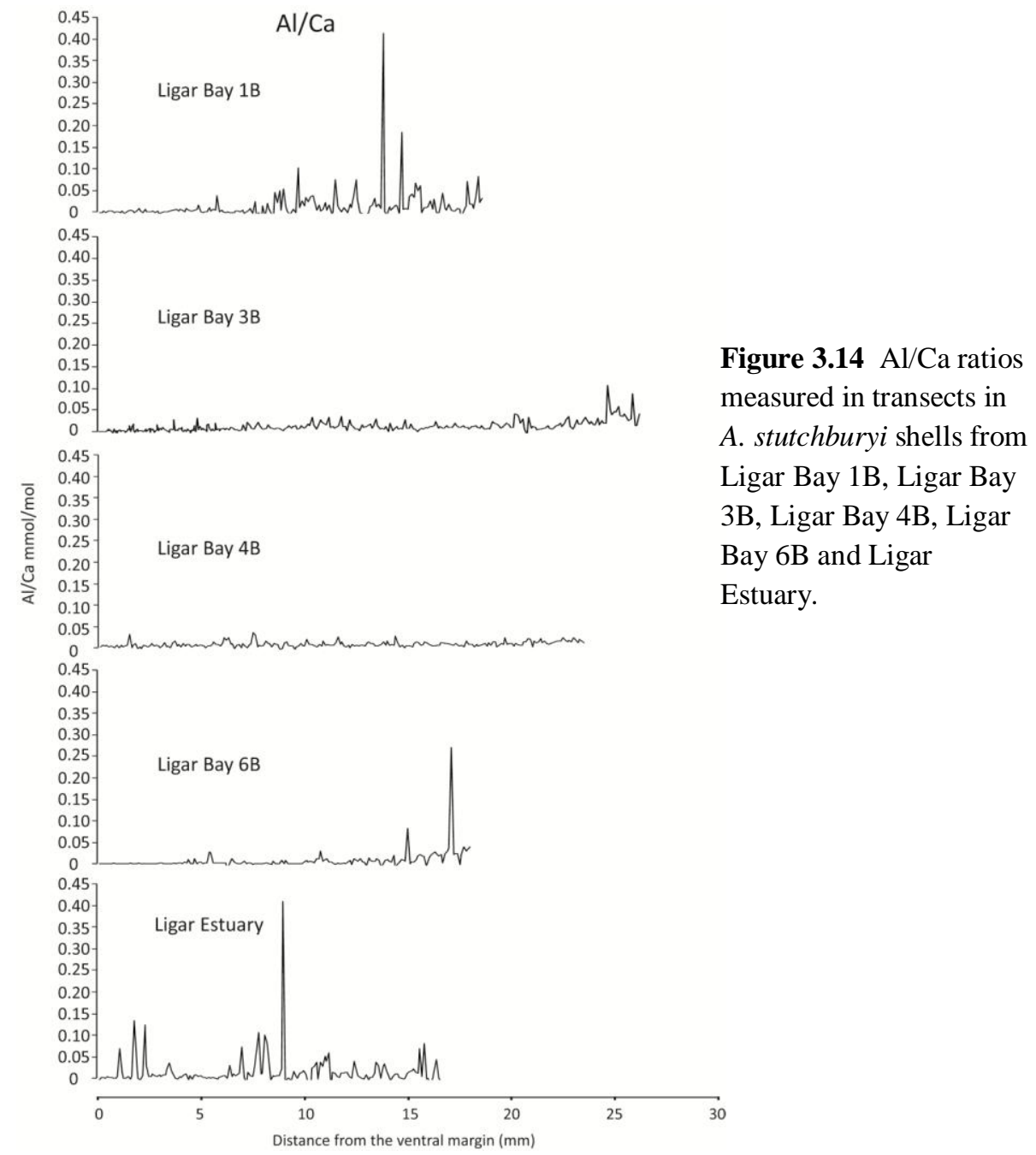

Table 3.1 Summary of the range in TE/Ca ratios for the Ligar Bay and Ligar Estuary shells.

\begin{tabular}{ccccccccccccc}
\multicolumn{10}{c}{$\mathrm{TE} / \mathrm{Ca}(\mathrm{mmol} / \mathrm{mol})$} \\
\hline Shell & & $\mathrm{Li} / \mathrm{Ca}$ & $\mathrm{B} / \mathrm{Ca}$ & $\mathrm{Mg} / \mathrm{Ca}$ & $\mathrm{Al} / \mathrm{Ca}$ & $\mathrm{Mn} / \mathrm{Ca}$ & $\mathrm{Cu} / \mathrm{Ca}$ & $\mathrm{Zn} / \mathrm{Ca}$ & $\mathrm{As} / \mathrm{Ca}$ & $\mathrm{Sr} / \mathrm{Ca}$ & $\mathrm{Ba} / \mathrm{Ca}$ & $\mathrm{U} / \mathrm{Ca}$ \\
\hline Ligar 1B & Minimum & - & - & 0.40 & 0.00 & 0.00 & - & 0.00 & - & 1.0 & 0.00048 & - \\
& Maximum & - & - & 3.9 & 0.41 & 0.011 & - & 0.026 & - & 3.0 & 0.017 & - \\
Ligar 3B & Minimum & 0.00 & 0.053 & 0.58 & 0.00 & 0.00 & 0.0016 & 0.00 & 0.00 & 0.98 & 0.00031 & 0.00 \\
& Maximum & 0.027 & 0.13 & 4.1 & 0.11 & 0.01 & 0.059 & 0.011 & 0.021 & 2.6 & 0.039 & 0.00044 \\
Ligar 4B & Minimum & 0.00 & 0.033 & 0.28 & 0.00 & 0.00 & 0.00025 & 0.00 & 0.00 & 1.0 & 0.00037 & 0.00 \\
& Maximum & 0.041 & 0.11 & 2.6 & 0.035 & 0.0066 & 0.0041 & 0.011 & 0.015 & 3.2 & 0.046 & 0.00047 \\
Ligar 6B & Minimum & - & - & 0.14 & 0.00 & 0.00 & 0.00066 & 0.00 & 0.00 & 1.0 & 0.00035 & 0.00 \\
& Maximum & - & - & 2.2 & 0.27 & 0.011 & 0.021 & 0.019 & 0.055 & 3.5 & 0.012 & 0.00078 \\
L. Estuary & Minimum & 0.00 & 0.053 & 0.42 & 0.00 & 0.00 & 0.00023 & 0.00 & 0.00 & 1.3 & 0.00065 & 0.00 \\
& Maximum & 0.040 & 0.32 & 4.0 & 0.57 & 0.37 & 0.044 & 0.020 & 0.048 & 3.2 & 0.0084 & 0.00082 \\
\hline & & & & & & & & & & & & \\
\hline
\end{tabular}




\subsubsection{Individual Ligar Bay transects}

\section{Ligar Bay $1 B$}

The $\mathrm{Mg} / \mathrm{Ca}$ record consists of high-frequency peak and troughs $(0-1 \mathrm{~mm})$, on either side of one larger semi-sinusoidal variation centred at $10 \mathrm{~mm}$ distance from the ventral margin (Figure 3.15). The $\mathrm{Mn} / \mathrm{Ca}$ and $\mathrm{Ba} / \mathrm{Ca}$ ratio records followed a similar pattern to $\mathrm{Mg} / \mathrm{Ca}$, but the variations between peaks and troughs are more exaggerated. $\mathrm{Sr} / \mathrm{Ca}$ ratios varied in a similar pattern to $\mathrm{Mg} / \mathrm{Ca}$ record, except there was no pronounced semi-sinusoidal change at ca. $10 \mathrm{~mm}$. The annual growth band G4 coincided with the minima on one side of this sinusoidal shape for $\mathrm{Mg} / \mathrm{Ca}, \mathrm{Mn} / \mathrm{Ca}$ and $\mathrm{Ba} / \mathrm{Ca}$ (Figure 3.15). The growth bands G2 and G4 appear to coincide with minima in the $\mathrm{Mg} / \mathrm{Ca}$ and $\mathrm{Mn} / \mathrm{Ca}$ records, but no other growth bands or increments appeared to correlate with the chemistry.

There is an ontogenetic decrease (i.e. a decrease in TE/Ca ratios as the clam grew older) in $\mathrm{Mg} / \mathrm{Ca}, \mathrm{Sr} / \mathrm{Ca}, \mathrm{Mn} / \mathrm{Ca}, \mathrm{Ba} / \mathrm{Ca}$ and $\mathrm{Zn} / \mathrm{Ca}$ ratios, as well a decrease in the amplitude of variations from peak to trough. For example, in the $\mathrm{Mg} / \mathrm{Ca}$ record, the difference between peak and trough decreased from $1.5 \mathrm{mmol} / \mathrm{mol}$ at $14 \mathrm{~mm}$, to $0.9 \mathrm{mmol} / \mathrm{mol}$ at 4 $\mathrm{mm}$ from the ventral margin. One variation in the older half of the $\mathrm{Zn} / \mathrm{Ca}$ record was an increase from $0.0004-0.026 \mathrm{mmol} / \mathrm{mol}$. However, in the $\mathrm{Ba} / \mathrm{Ca}$ record, a sharp peak to $0.017 \mathrm{mmol} / \mathrm{mol}$ at $4.2 \mathrm{~mm}$ from the ventral margin interrupted the trend of lower amplitude $\mathrm{Ba} / \mathrm{Ca}$ ratio variations seen in the younger part of the shell.

\section{Ligar Bay 3B}

In the Ligar Bay 3B shell, $\mathrm{Mg} / \mathrm{Ca}$ and $\mathrm{Sr} / \mathrm{Ca}$ records were characterised by four sharp increases and decreases $(0.5-1.0 \mathrm{mmol} / \mathrm{mol})$ at 25, 22, 14, 9 (for $\mathrm{Sr} / \mathrm{Ca}$ ) and $6 \mathrm{~mm}$ distance from the ventral margin, which were interspersed with periods with smaller 
ratio variations $(0-0.5 \mathrm{mmol} / \mathrm{mol})$. Two of these decreases, at $6 \mathrm{~mm}$ and $14 \mathrm{~mm}$, coincided with the annual growth bands G4 and G5 (Figure 3.16). In the $\mathrm{Mg} / \mathrm{Ca}$ record, which was smoother than the $\mathrm{Sr} / \mathrm{Ca}$ record, the ratios within 6-0 $\mathrm{mm}$ distance from the ventral margin, in the youngest portion of the record, form an almost sinusoidal shape. One annual growth band (G2) sat on a small decrease that interrupted this sinusoidal shape, and another (G3) was situated at the base of the shape at $4.5 \mathrm{~mm}$ (Figure 3.16). $\mathrm{Mn} / \mathrm{Ca}$ ratios and $\mathrm{U} / \mathrm{Ca}$ ratios both followed a similar pattern to $\mathrm{Mg} / \mathrm{Ca}$ and $\mathrm{Sr} / \mathrm{Ca}$ but with larger (relative) variations. The predominant feature in the $\mathrm{Ba} / \mathrm{Ca}$ record was the 3-point peak (up to $0.039 \mathrm{mmol} / \mathrm{mol}$ ) around $7-9 \mathrm{~mm}$ distance from the ventral margin. However, when this peak was excluded from the $\mathrm{Ba} / \mathrm{Ca}$ data, the remaining $\mathrm{Ba} / \mathrm{Ca}$ record was similar to the $\mathrm{Mn} / \mathrm{Ca}$ record in the Ligar Bay $3 \mathrm{~B}$ transect, and the $\mathrm{Ba} / \mathrm{Ca}$ ratios were within a range comparable to those in Ligar Bay1B, not being higher than $0.016 \mathrm{mmol} / \mathrm{mol}$. All the TE/Ca records taken in the Ligar Bay 3B shell showed an ontogenetic decrease accompanied by a decrease in the amplitude of variations, although this did not occur for the $\mathrm{Cu} / \mathrm{Ca}, \mathrm{B} / \mathrm{Ca}$ and $\mathrm{Li} / \mathrm{Ca}$ ratios (Figure 3.9, 3.12 and 3.13). 


\section{Ligar Bay 1B}

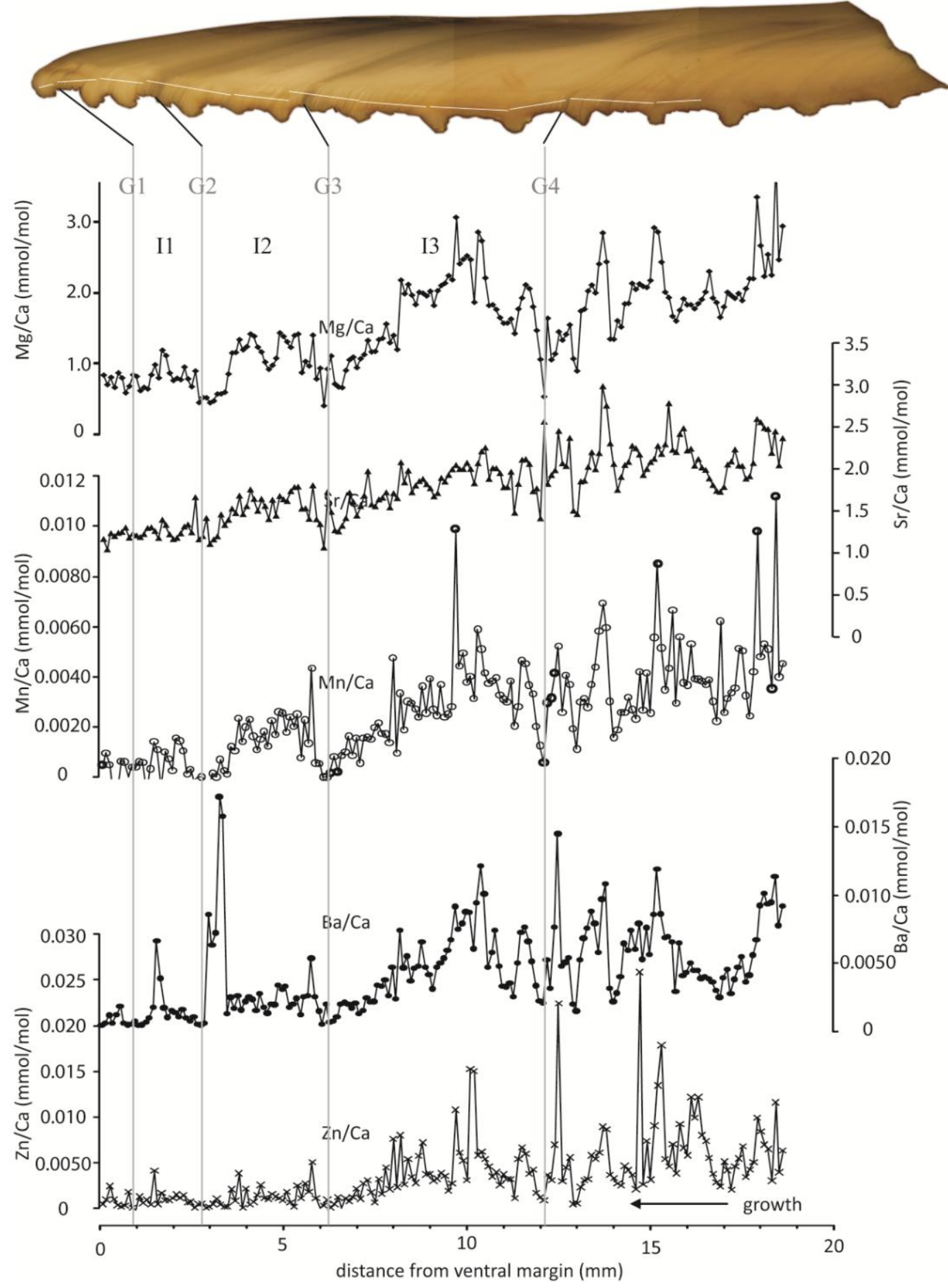

Figure 3.15 Ligar Bay 1B TE/Ca ratios transects: $\mathrm{Mg} / \mathrm{Ca}, \mathrm{Sr} / \mathrm{Ca}, \mathrm{Mn} / \mathrm{Ca}, \mathrm{Ba} / \mathrm{Ca}$ and $\mathrm{Zn} / \mathrm{Ca}$.Grey lines are annual growth bands identified on the shell (photograph) I1-I3 refer to the annual growth increments identified. White lines on the shell show the path of LA-ICP-MS analysis. 
Ligar Bay 3B

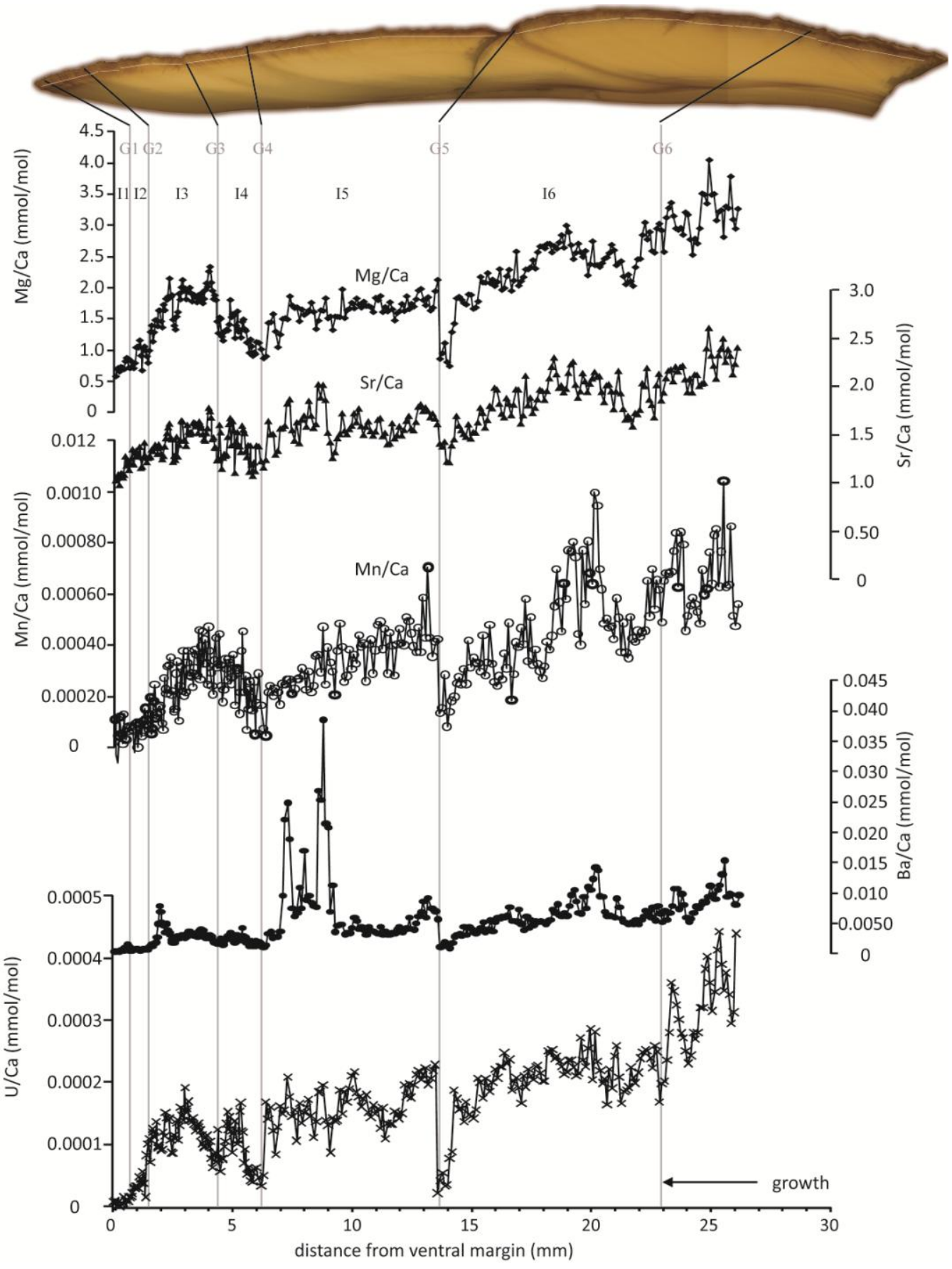

Figure 3.16 Ligar Bay 3B TE/Ca ratios transects: $\mathrm{Mg} / \mathrm{Ca}, \mathrm{Sr} / \mathrm{Ca}, \mathrm{Mn} / \mathrm{Ca}, \mathrm{Ba} / \mathrm{Ca}$ and $\mathrm{U} / \mathrm{Ca}$. Grey lines are annual growth bands identified on the shell (photograph) I1-I6 refer to the identified annual growth increments. White lines on the shell mark the path of LA-ICP-MS analysis. 


\section{Ligar $4 B$}

Throughout the $\mathrm{Mg} / \mathrm{Ca}$ record there were few variations greater than $0.40 \mathrm{mmol} / \mathrm{mol}$, apart from a $\sim 0.80 \mathrm{mmol} / \mathrm{mol}$ decrease at $15 \mathrm{~mm}$ from the ventral margin, and a gradual decrease of $\sim 1.2 \mathrm{mmol} / \mathrm{mol}$ in the $2 \mathrm{~mm}$ closest to the ventral margin (Figure 3.17 ). The $\mathrm{Sr} / \mathrm{Ca}$ record differed from the $\mathrm{Mg} / \mathrm{Ca}$ record in that it contained three peaks, at 5, 11,14 and $17 \mathrm{~mm}$ from the ventral margin, amongst the periods with smaller variations. $\mathrm{Mn} / \mathrm{Ca}$ ratios formed a record with reasonably uniform variations across it (between 0.0005-0.0010 mmol/mol). Ba/Ca ratios in the Ligar Bay $4 \mathrm{~B}$ shell were quite similar to the Ligar Bay 3B record, including the 3-point peak. Excluding the 3-point peak, the $\mathrm{Ba} / \mathrm{Ca}$ ratios were not above $0.010 \mathrm{mmol} / \mathrm{mol}$ in the Ligar Bay $4 \mathrm{~B}$ shell. $\mathrm{U} / \mathrm{Ca}$ ratios followed a similar pattern as the $\mathrm{Sr} / \mathrm{Ca}$ record, but with greater variation. As with the previously described Ligar Bay shells, there was an ontogenetic decrease in TE/Ca ratios accompanied by a decrease in the amplitude of variations, although this was not evident for $\mathrm{Cu} / \mathrm{Ca}, \mathrm{B} / \mathrm{Ca}, \mathrm{Al} / \mathrm{Ca}$ and $\mathrm{Li} / \mathrm{Ca}$ ratios. The growth patterns identified in $4 \mathrm{~B}$ did not appear to correlate with the chemistry, except for one annual growth band - G5, which coincided with the beginning of the largest decreases in the $\mathrm{Mg} / \mathrm{Ca}, \mathrm{Sr} / \mathrm{Ca}$, $\mathrm{Mn} / \mathrm{Ca}, \mathrm{Ba} / \mathrm{Ca}$ and $\mathrm{U} / \mathrm{Ca}$ records $\sim 15 \mathrm{~mm}$ from the ventral margin.

\section{Ligar Bay $6 B$}

The youngest portion of the $\mathrm{Mg} / \mathrm{Ca}$ record had a small peak to $1.0 \mathrm{mmol} / \mathrm{mol}$, but then was flat, not exceeding $0.60 \mathrm{mmol} / \mathrm{mol}$, until $9 \mathrm{~mm}$ from the ventral margin. After this distance, there were two sinusoidal patterns in the record, centred at 10 and $12 \mathrm{~mm}$ from the ventral margin, followed by a larger semi-sinusoidal shape that contained sharp variations with a peak at $16 \mathrm{~mm}$ from the ventral margin (Figure 3.18). The $\mathrm{Mn} / \mathrm{Ca}$, $\mathrm{Ba} / \mathrm{Ca}$ and $\mathrm{U} / \mathrm{Ca}$ ratios had records that were very similar to this pattern. However, the $\mathrm{Sr} / \mathrm{Ca}$ record was quite unusual in the Ligar Bay $6 \mathrm{~B}$ shell. 


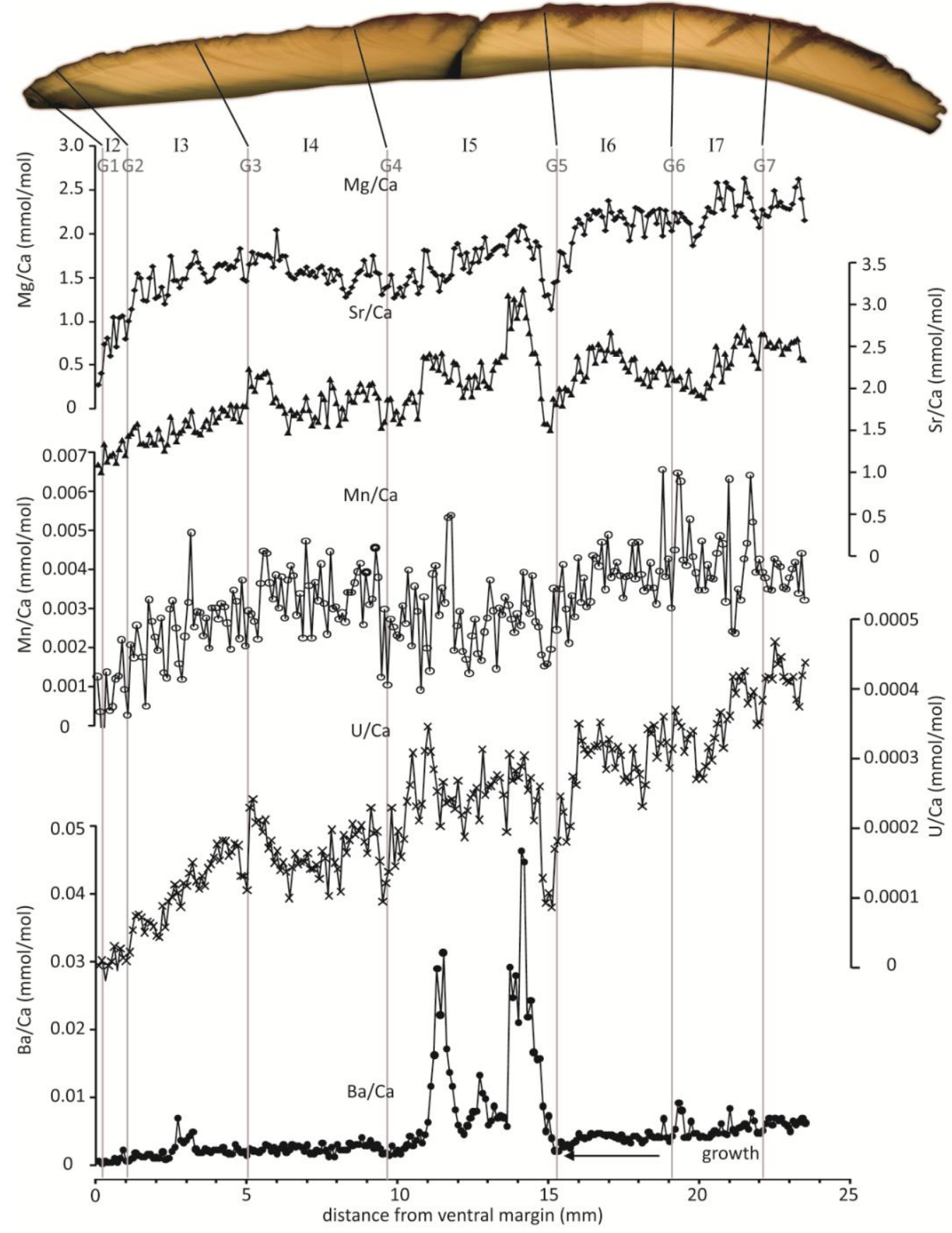

Figure 3.17 Ligar 4B TE/Ca ratios transects: $\mathrm{Mg} / \mathrm{Ca}, \mathrm{Sr} / \mathrm{Ca}, \mathrm{Mn} / \mathrm{Ca}, \mathrm{Ba} / \mathrm{Ca}$ and $\mathrm{U} / \mathrm{Ca}$.Grey lines are annual growth bands identified on the shell (photograph) I1-I6 refer to the identified annual growth increments. 


\section{Ligar Bay 6B}

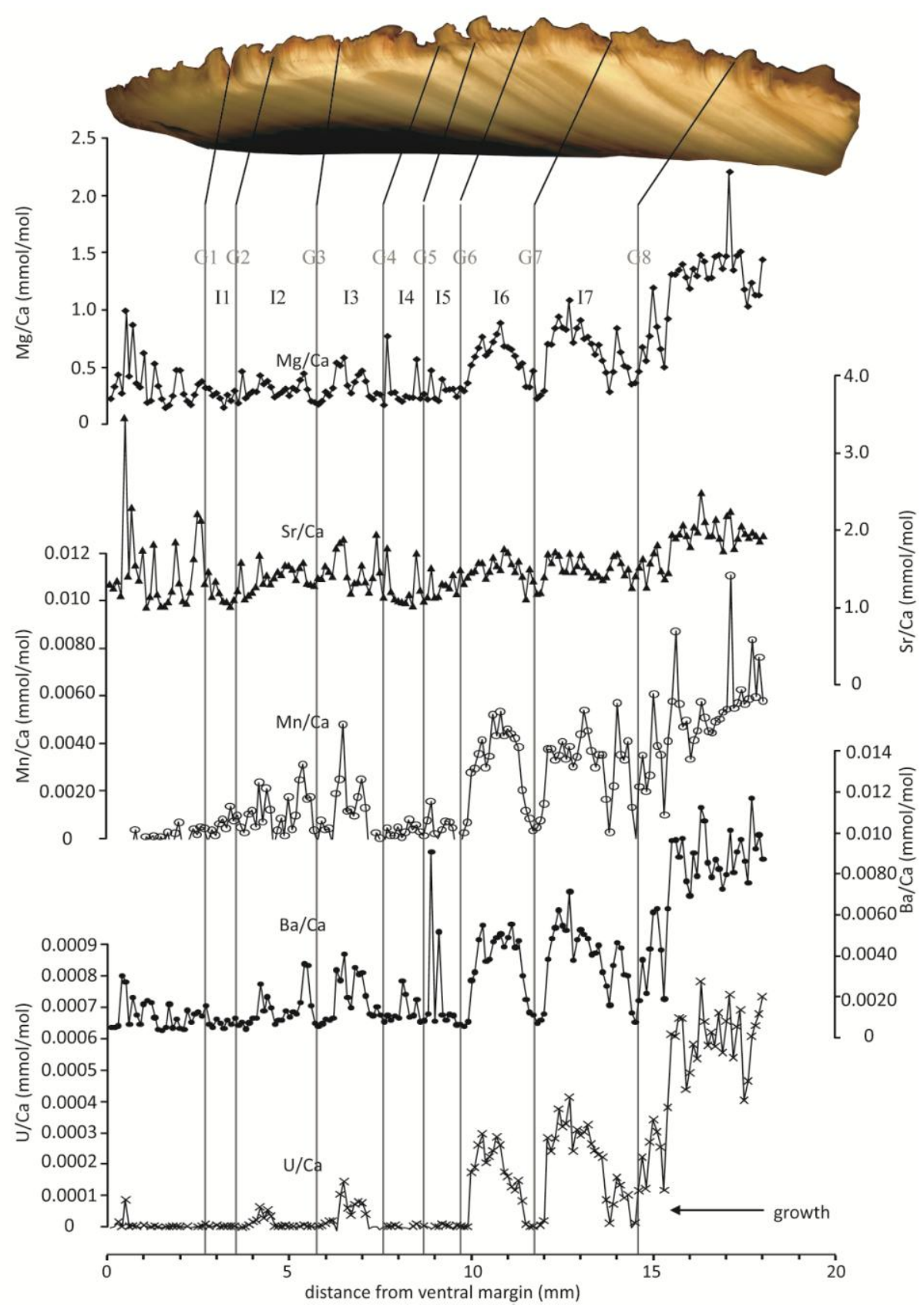

Figure 3.18 Ligar 4B TE/Ca ratios transects: $\mathrm{Mg} / \mathrm{Ca}, \mathrm{Sr} / \mathrm{Ca}, \mathrm{Mn} / \mathrm{Ca}, \mathrm{Ba} / \mathrm{Ca}$ and $\mathrm{U} / \mathrm{Ca}$. Grey lines are annual growth bands identified on the shell (photograph) I1I6 refer to the identified annual growth increments. 
It consisted of quite sharp variations (up to $2.3 \mathrm{mmol} / \mathrm{mol}$ increases) in the youngest part of the transect, within $0-8 \mathrm{~mm}$ distance of the ventral margin, and the latter half of the record appeared to be a muted version of the patterns seen in the latter half of the $\mathrm{Mg} / \mathrm{Ca}, \mathrm{U} / \mathrm{Ca}, \mathrm{Mn}$ and $\mathrm{Ba} / \mathrm{Ca}$ records. Apart from $\mathrm{Sr} / \mathrm{Ca}$ and $\mathrm{Cu} / \mathrm{Ca}$ ratios, there was an ontogenetic decrease in TE/Ca ratios accompanied by a decrease in the amplitude of variations. For example in the $\mathrm{Mn} / \mathrm{Ca}$ record, ratios in the oldest portion are an order of magnitude larger than at the end of the clam's life (0.0011 compared to 0.00010 $\mathrm{mmol} / \mathrm{mol}$ ). There was some correlation between shell chemistry and annual growth bands - as growth bands G6, G7 and G8 coincided with minima of the sinusoidal chemical variations observed (Figure 3.18).

\section{Ligar Estuary}

The Ligar Estuary $\mathrm{Mg} / \mathrm{Ca}$ record was most similar to the Ligar Bay $1 \mathrm{~B}$ record and contained more and larger variations than the other Ligar Bay shell records (Figure 3.19). In the available $\mathrm{Sr} / \mathrm{Ca}$ record (6.6-15 $\mathrm{mm}$ from the ventral margin) ratios followed the $\mathrm{Mg} / \mathrm{Ca}$ record. $\mathrm{Ba} / \mathrm{Ca}$ and $\mathrm{U} / \mathrm{Ca}$ ratios also followed the same pattern; which was similar to the $\mathrm{Mg} / \mathrm{Ca}$ record. The pattern of the $\mathrm{Mn} / \mathrm{Ca}$ record was also similar except for seven large spikes superimposed on it, the largest of which was a sharp increase of $0.37 \mathrm{mmol} / \mathrm{mol}$. The was no clear trend of ontogenetic decrease in $\mathrm{TE} / \mathrm{Ca}$ ratios observed in the Ligar Estuary records, except for the $\mathrm{Mg} / \mathrm{Ca}$ record; although it was less pronounced than the ontogenetic decreases observed in the Ligar Bay shells. In fact, in many of the TE/Ca records $-\mathrm{Ba} / \mathrm{Ca}, \mathrm{U} / \mathrm{Ca}, \mathrm{Zn} / \mathrm{Ca}, \mathrm{B} / \mathrm{Ca}$ and $\mathrm{Cu} / \mathrm{Ca}$ - there were larger variations in the younger sections. In others $-\mathrm{As} / \mathrm{Ca}$ and $\mathrm{Al} / \mathrm{Ca}$ - there were sharp increases throughout the record (Figures 3.9-3.14). 


\section{Ligar Estuary}
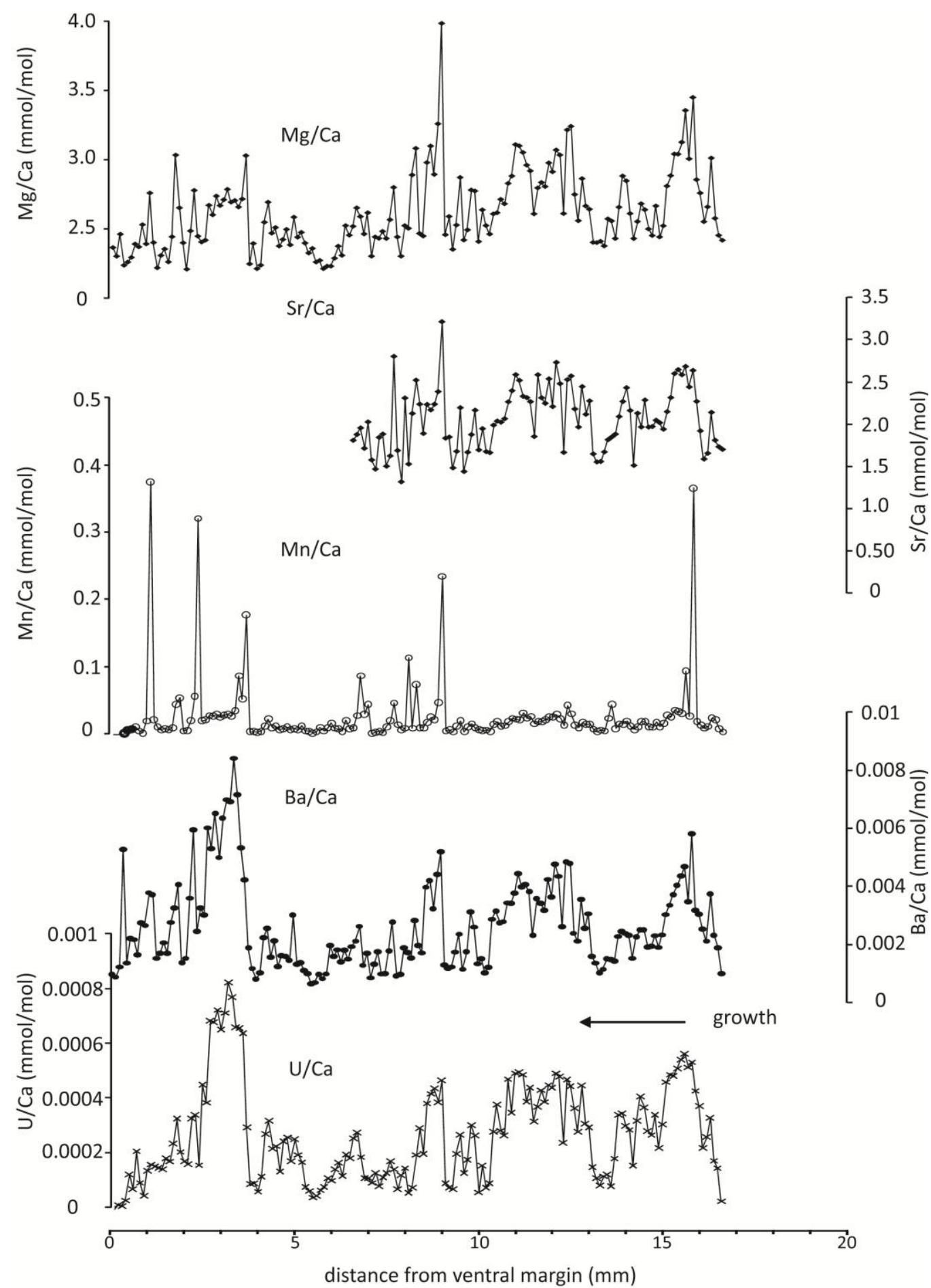

Figure 3.19 Ligar Estuary TE/Ca ratios transects: $\mathrm{Mg} / \mathrm{Ca}, \mathrm{Sr} / \mathrm{Ca}, \mathrm{Mn} / \mathrm{Ca}$, $\mathrm{Ba} / \mathrm{Ca}$ and $\mathrm{U} / \mathrm{Ca}$. 


\subsubsection{Trace element/Ca ratio transects for A. stutchburyi at other New Zealand sites}

\section{Kawhia}

The Kawhia $\mathrm{Mg} / \mathrm{Ca}, \mathrm{Sr} / \mathrm{Ca}, \mathrm{Mn} / \mathrm{Ca}, \mathrm{Ba} / \mathrm{Ca}$ and $\mathrm{U} / \mathrm{Ca}$ records consisted of a series of peak-trough variations ( $<1 \mathrm{~mm}$ width), and one saw-tooth pattern from $8-13 \mathrm{~mm}$ from the ventral margin on which these variations were superimposed (Figure 3.20). The $\mathrm{Mn} / \mathrm{Ca}, \mathrm{Sr} / \mathrm{Ca}$ and $\mathrm{U} / \mathrm{Ca}$ ratio variations appeared more amplified than the variations in the $\mathrm{Ba} / \mathrm{Ca}$ and $\mathrm{Mg} / \mathrm{Ca}$ records. There was a significant ontogenetic decrease and decrease in the amplitude of variations for all TE/Ca ratio records, except for in the $\mathrm{Zn} / \mathrm{Ca}$ and $\mathrm{Cu} / \mathrm{Ca}$ records. The relative ontogenetic decreases observed were similar to those found in the Ligar Bay shells - for example $\mathrm{Mn} / \mathrm{Ca}$ ratios decrease by one order of magnitude from the oldest region of the shell to the youngest (even though $\mathrm{Mn} / \mathrm{Ca}$ ratios overall were higher at Kawhia than in the Ligar shells).

Raglan

The $\mathrm{Mg} / \mathrm{Ca}, \mathrm{Sr} / \mathrm{Ca}, \mathrm{Mn} / \mathrm{Ca}, \mathrm{Ba} / \mathrm{Ca}$ and $\mathrm{U} / \mathrm{Ca}$ records in the Raglan shell mostly consist of small variations (e.g. $<0.5 \mathrm{mmol} / \mathrm{mol}$ for $\mathrm{Mg} / \mathrm{Ca}$ ratios) interrupted by several sharp larger variations (up to $1.0 \mathrm{mmol} / \mathrm{mol}$ for $\mathrm{Mg} / \mathrm{Ca}$ ) (Figure 3.21). There was a large decrease in $\mathrm{Mn} / \mathrm{Ca}, \mathrm{Mg} / \mathrm{Ca}$ and $\mathrm{U} / \mathrm{Ca}$ ratios $6-5 \mathrm{~mm}$ from the ventral margin to much lower ratios in the youngest portion of the shell. This change was preceded by a decrease in ratios $11 \mathrm{~mm}$ from the ventral margin, of comparable amplitude, which interrupted higher TE/Ca ratios in the older section of the shell. An ontogenetic decrease was also observed in the $\mathrm{Sr} / \mathrm{Ca}$ and $\mathrm{Ba} / \mathrm{Ca}$ records, although it was less amplified. 

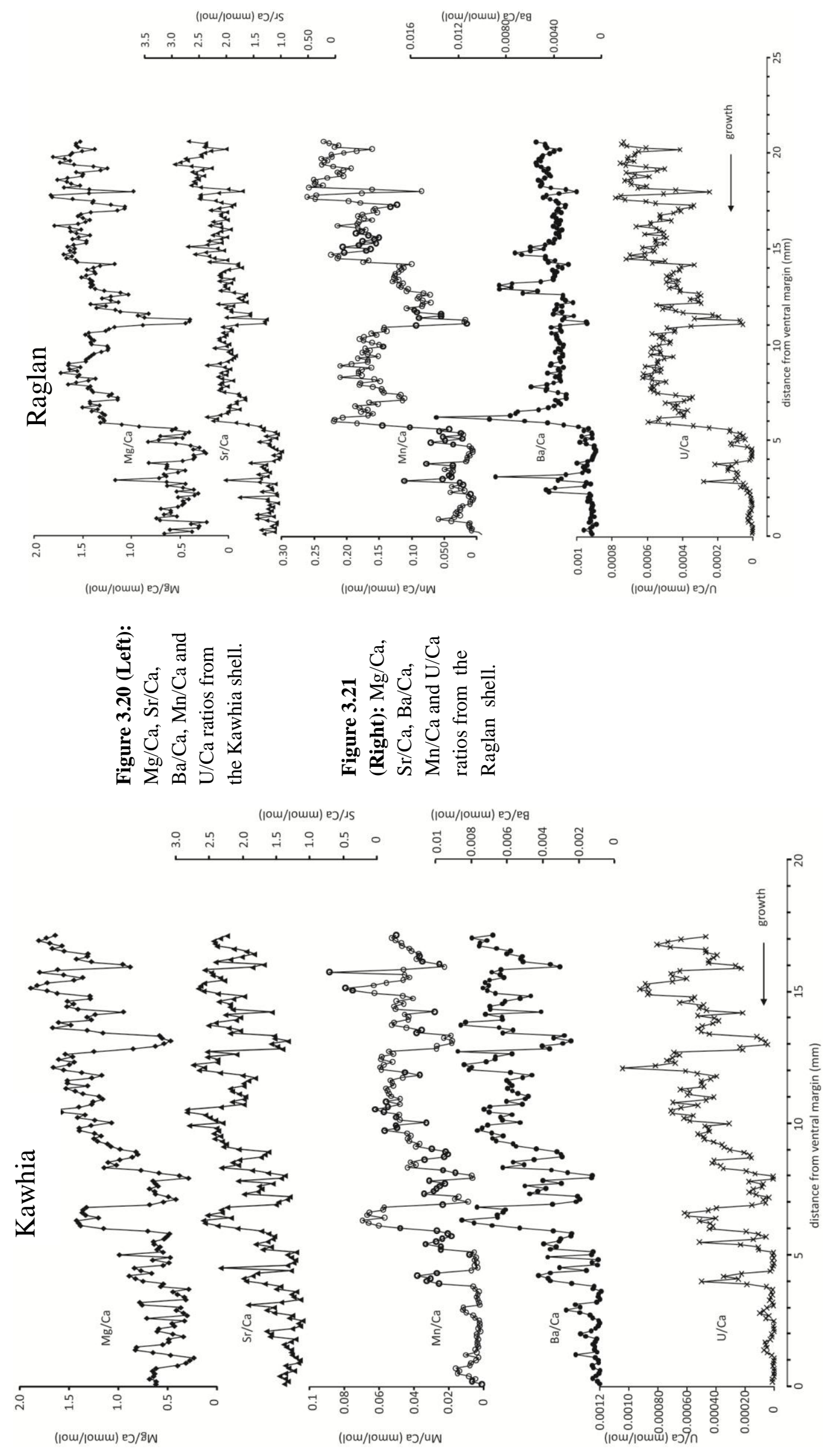

69 


\section{Miranda}

The $\mathrm{Mg} / \mathrm{Ca}, \mathrm{Sr} / \mathrm{Ca}, \mathrm{Ba} / \mathrm{Ca}$ and $\mathrm{U} / \mathrm{Ca}$ records in the Miranda shell were characterised by moderate variations $(\sim 0.5, \sim 0.6, \sim 0.005$ and $0.0003 \mathrm{mmol} / \mathrm{mol}$, respectively $)$ superimposed on a gradual ontogenetic decrease in TE/Ca ratios (Figure 3.22). Whereas a decrease in the amplitude in variations commonly accompanied the ontogenetic decrease in ratios in the other shell records, this was not the case in for $\mathrm{Mg} / \mathrm{Ca}, \mathrm{Sr} / \mathrm{Ca}, \mathrm{Ba} / \mathrm{Ca}$ and $\mathrm{U} / \mathrm{Ca}$ in the Miranda shell. $\mathrm{Mn} / \mathrm{Ca}$ ratios exhibited a wide range, between $0.00-1.60 \mathrm{mmol} / \mathrm{mol}$, and the $\mathrm{Mn} / \mathrm{Ca}$ record included three large peaks, which apart from this was comparable to the $\mathrm{Mg} / \mathrm{Ca}, \mathrm{Sr} / \mathrm{Ca}, \mathrm{Ba} / \mathrm{Ca}$ and $\mathrm{U} / \mathrm{Ca}$ records.

\section{Kaiaua}

The records of $\mathrm{Mg} / \mathrm{Ca}, \mathrm{Mn} / \mathrm{Ca}, \mathrm{Ba} / \mathrm{Ca}$ and $\mathrm{U} / \mathrm{Ca}$ in the Kaiaua shell consisted of a series of sinusoidal variations, which was unique out of all the A. stutchburyi analysed (Figure 3.23). The amplitude and width of these variations generally decreased from the older sections to the youngest section. For example, in the $\mathrm{Mg} / \mathrm{Ca}$ record, the penultimate variation stretches over $\sim 4 \mathrm{~mm}$ (from trough-trough), whereas the three sinusoidal variations located between 5.5-2.5 $\mathrm{mm}$ from the ventral margin are each only approximately $0.75 \mathrm{~mm}$ from trough-trough. This pattern of variation was also present in the $\mathrm{Sr} / \mathrm{Ca}$ record, although the variations were more subdued. 


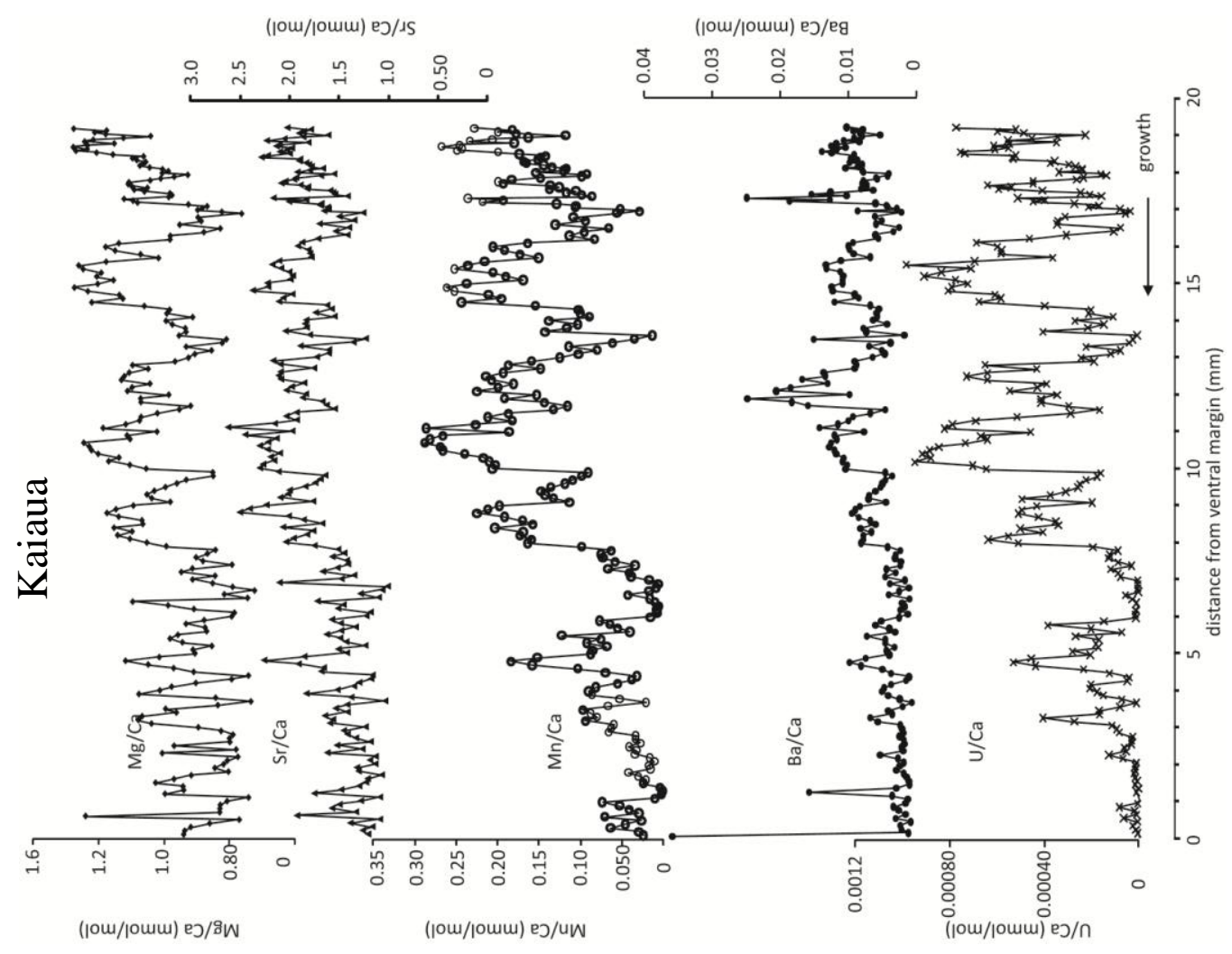

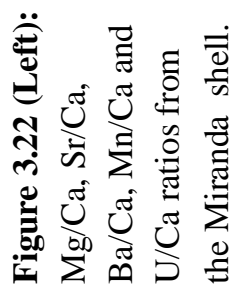

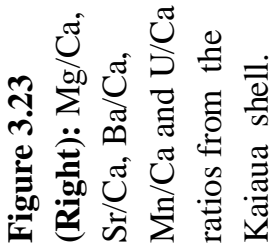

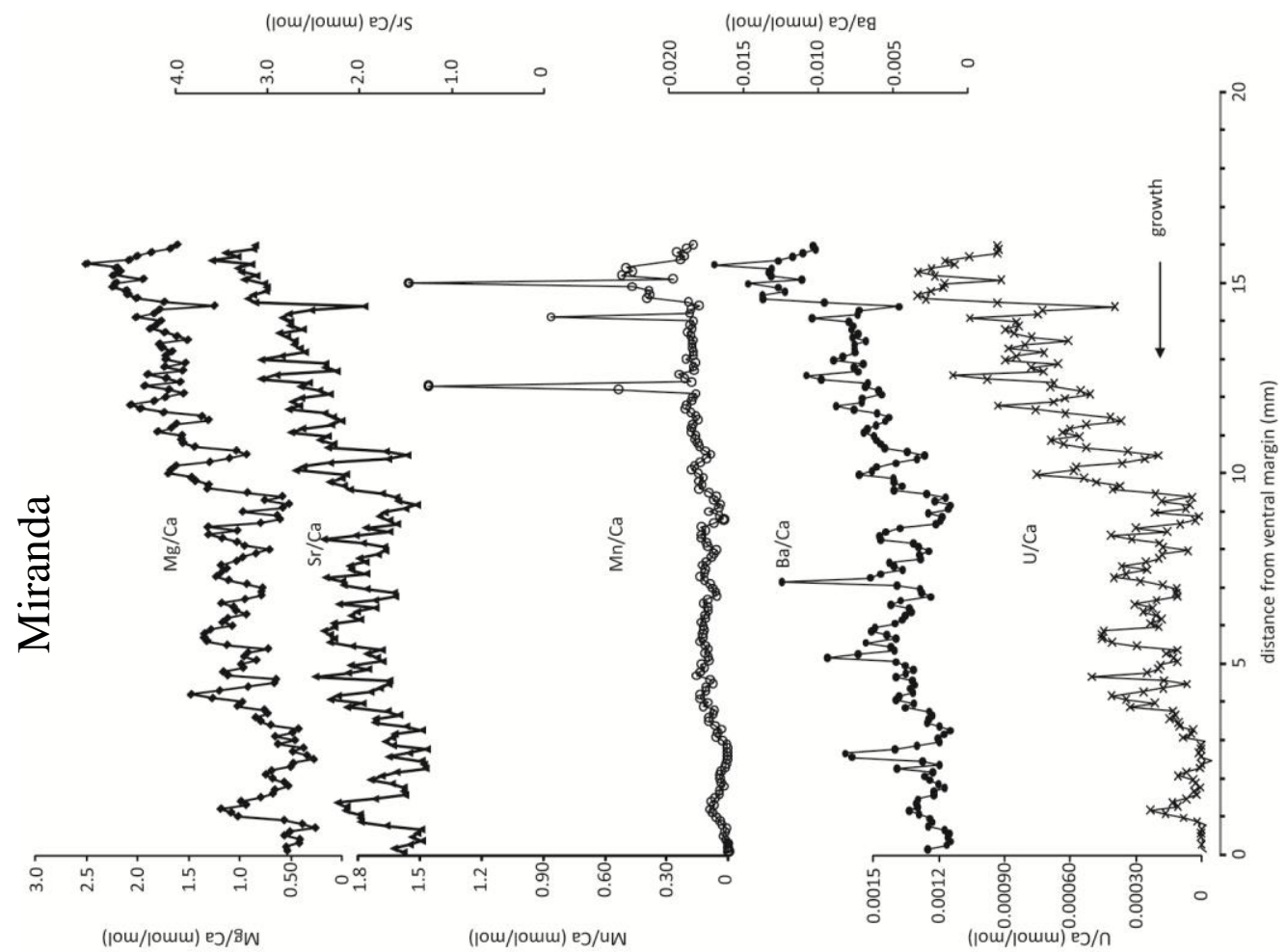



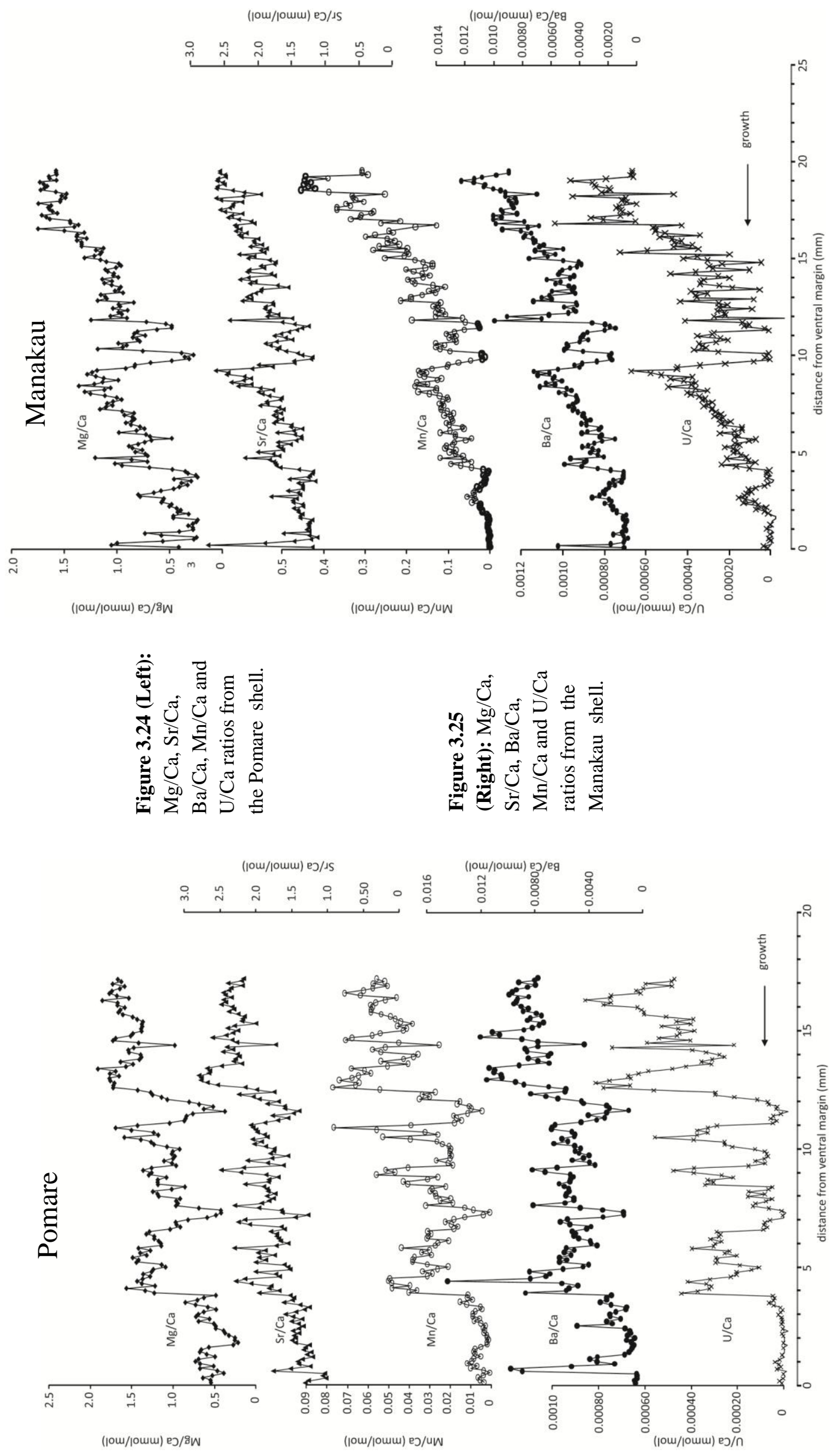


\section{Pomare}

The Pomare shell $\mathrm{Mg} / \mathrm{Ca}, \mathrm{Mn} / \mathrm{Ca}, \mathrm{U} / \mathrm{Ca}, \mathrm{Ba} / \mathrm{Ca}$ and $\mathrm{Sr} / \mathrm{Ca}$ records consisted of semisinusoidal variations, with significant troughs located at 4,7 and $11.5 \mathrm{~mm}$ from the ventral margin (Figure 3.24). There was an ontogenetic decrease in ratios and the amplitude of the ratio variations generally decreased in the younger sections of the shell; except for the $\mathrm{Ba} / \mathrm{Ca}$ record, which contained two spikes at 4.4 and $7 \mathrm{~mm}$ from the ventral margin.

\section{Manakau Harbour}

Each of the $\mathrm{Mg} / \mathrm{Ca}, \mathrm{Mn} / \mathrm{Ca}, \mathrm{Sr} / \mathrm{Ca}, \mathrm{U} / \mathrm{Ca}$, and $\mathrm{Ba} / \mathrm{Ca}$ records from the Manakau Harbour shell contained two saw-tooth patterns, which were separated by a large decrease in ratios at $\sim 10 \mathrm{~mm}$ from the ventral margin (Figure 3.25). As seen in several of the other shells with higher average $\mathrm{Mn} / \mathrm{Ca}$ ratios, there were several spikes in $\mathrm{Mn} / \mathrm{Ca}$ superimposed on this pattern in the oldest section of the record. There was a significant ontogenetic decrease over the $\mathrm{Mg} / \mathrm{Ca}, \mathrm{Mn} / \mathrm{Ca}, \mathrm{Sr} / \mathrm{Ca}, \mathrm{U} / \mathrm{Ca}$, and $\mathrm{Ba} / \mathrm{Ca}$ records, although this was not present in the other TE/Ca records. In the $\mathrm{B} / \mathrm{Ca}$ record there was an ontogenetic increase.

\subsubsection{Inner versus outer shell averages}

The general trend of decreasing TE/Ca ratios with the age of the clam can most clearly be observed in a comparison of the averages of the ratios measured from the half of each shell transect closest to the umbo (the "inner" half), with the averages of the ratios measured from the outside half of each shell transect closest to the ventral margin (the “outer" half) (Figures 3.26-3.27). Except for Ligar Estuary, this was the case for $\mathrm{Mg} / \mathrm{Ca}$, $\mathrm{Al} / \mathrm{Ca}, \mathrm{Li} / \mathrm{Ca}, \mathrm{Sr} / \mathrm{Ca}, \mathrm{Ba} / \mathrm{Ca}, \mathrm{U} / \mathrm{Ca}, \mathrm{Mn} / \mathrm{Ca}$ and $\mathrm{As} / \mathrm{Ca}$ shell ratios, where all inner shell ratio averages were higher than outer shell ratio averages, indicating that more of those 
trace elements were substituted for $\mathrm{Ca}$ in the earlier stages of each clam's life. For example $\mathrm{Mg} / \mathrm{Ca}$ ratios were on average between $0.5-1.0 \mathrm{mmol} / \mathrm{mol}$ greater in the oldest halves of each shell. For the $\mathrm{Cu} / \mathrm{Ca}, \mathrm{B} / \mathrm{Ca}$ and $\mathrm{Zn} / \mathrm{Ca}$ shell ratios this pattern was not evident; average B/Ca shell ratios remained very similar in both sections of the shell for all samples, while $\mathrm{Zn} / \mathrm{Ca}$ and $\mathrm{Cu} / \mathrm{Ca}$ average ratios were variable between inner and outer sections, across the samples.

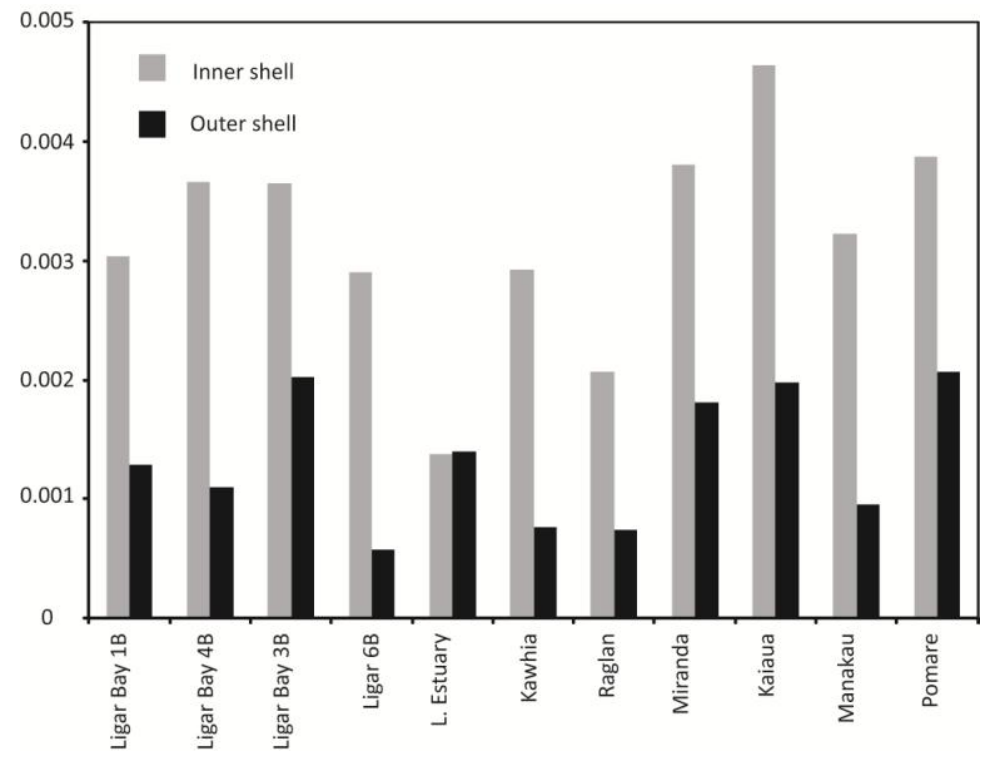

Figure 3.26

Comparison of average $\mathrm{Mg} / \mathrm{Ca}$ ratios from the inner (oldest) transect of the A. stutchburyi shells and outer (youngest) half of the shells.

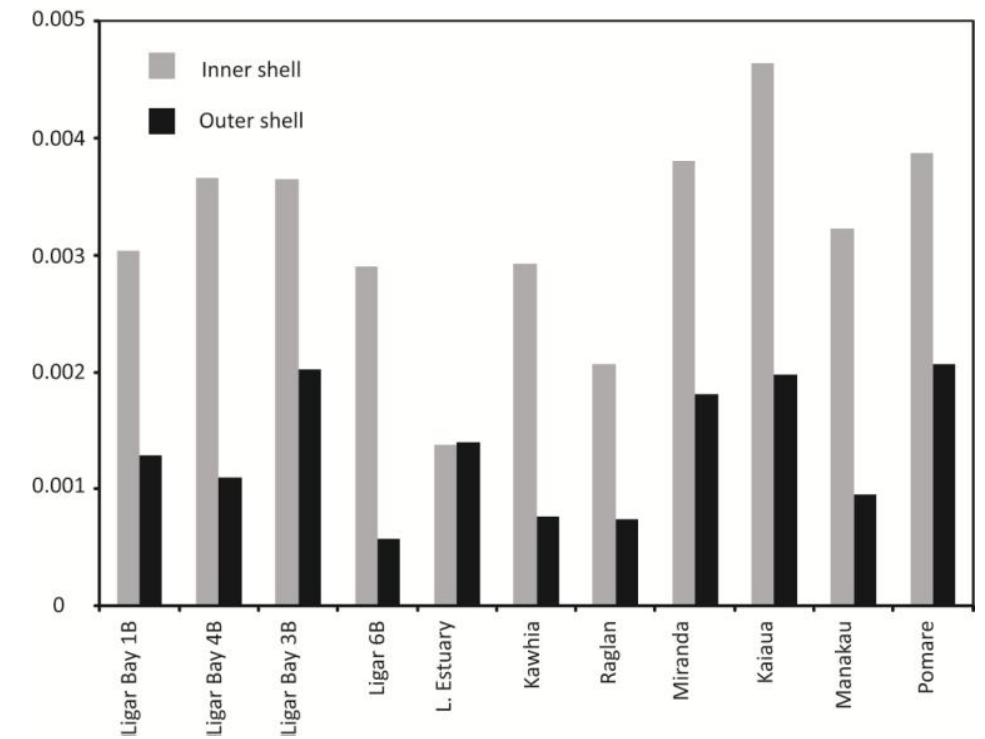

Figure 3.27

Comparison of average $\mathrm{Ba} / \mathrm{Ca}$ ratios from the inner (oldest) transect of the A. stutchburyi shells and outer (youngest) half of the shells. 


\subsubsection{Correlations between trace elements}

There was a significant correlation throughout the dataset for all A. stutchburyi shells from all sites of $\mathrm{Mg} / \mathrm{Ca}$ ratios, with $\mathrm{Mn} / \mathrm{Ca}, \mathrm{Sr} / \mathrm{Ca}, \mathrm{Ba} / \mathrm{Ca}$ and $\mathrm{U} / \mathrm{Ca}$ ratios (Table 3.2). The strongest correlations were observed between $\mathrm{Mg} / \mathrm{Ca}$ ratios and $\mathrm{U} / \mathrm{Ca}$ ratios in the Raglan and Miranda shells, which displayed linear regressions with $r^{2}$ values of 0.92 and 0.91 respectively. The only weak correlation between $\mathrm{Mg} / \mathrm{Ca}$ and $\mathrm{U} / \mathrm{Ca}\left(\mathrm{r}^{2}=0.45\right)$ was in the Ligar Estuary shell - all other $\mathrm{Mg} / \mathrm{Ca}-\mathrm{U} / \mathrm{Ca}$ correlations had $\mathrm{r}^{2}>0.72 . \mathrm{Mg} / \mathrm{Ca}$ always showed a significant correlation with $\mathrm{Sr} / \mathrm{Ca}$, with $\mathrm{r}^{2}$ values ranging between 0.56-0.86. Correlations between $\mathrm{Mg} / \mathrm{Ca}$ and $\mathrm{Mn} / \mathrm{Ca}$ were typically significant, except for two exceptions - the Ligar Estuary $\left(r^{2}=0.28\right)$ shell, and Ligar $4 \mathrm{~B}\left(\mathrm{r}^{2}=0.42\right)$. For half of the shells there was a strong correlation between $\mathrm{Mg} / \mathrm{Ca}$ and $\mathrm{Ba} / \mathrm{Ca}$, but for the remaining shells, correlation was insignificant (e.g. Ligar Bay $4 \mathrm{~B} \mathrm{r}^{2}=0.051$ and Ligar $\left.3 \mathrm{~B} \mathrm{r}^{2}=0.21\right)$.

The slopes, for the $\mathrm{Mg} / \mathrm{Ca}-\mathrm{U} / \mathrm{Ca}$ regressions, and thus sensitivity of co-variation, were similar between sites and also between shells within the Ligar Bay site (Table 3.2). The sensitivity of the other trace element correlations with $\mathrm{Mg} / \mathrm{Ca}$ was more variable, particularly the linear regressions for $\mathrm{Mn} / \mathrm{Ca}-\mathrm{Mg} / \mathrm{Ca}$, where the highest slope (0.27) was two orders of magnitude higher than the lowest (0.0026). However, the Ligar Bay shells tended to have similar slopes when plotted against $\mathrm{Ba} / \mathrm{Ca}$ and $\mathrm{Mn} / \mathrm{Ca}$.

Additionally, there were noticeable correlations between $\mathrm{Mn}, \mathrm{Ba}, \mathrm{Sr}$ and $\mathrm{U} . \mathrm{Mn} / \mathrm{Ca}$ ratios correlated significantly with $\mathrm{Ba} / \mathrm{Ca}, \mathrm{Sr} / \mathrm{Ca}$ and $\mathrm{U} / \mathrm{Ca}\left(\mathrm{r}^{2}=0.60-0.92\right)$ in all but the Ligar Bay shells; although these had low average $\mathrm{Mn} / \mathrm{Ca}$ ratios (Figure 3.30). The slope values varied within each correlation with $\mathrm{Mn}$ by up to an order of magnitude. $\mathrm{Sr} / \mathrm{Ca}$ showed some strong correlations with $\mathrm{Ba} / \mathrm{Ca}$ in most of the dataset $\left(\mathrm{r}^{2}=0.46-0.87\right)$, but not within the Ligar Bay shells or the Ligar Estuary shell. Similarly, Sr/Ca and U/Ca 
were strongly correlated $\left(r^{2}=0.66-0.90\right)$ within each of the shells except for Ligar Estuary and Ligar 6B. The sensitivity for these correlations with $\mathrm{Sr}$ was less variable than when Mn was included, especially $\mathrm{Sr} / \mathrm{Ca}-\mathrm{U} / \mathrm{Ca}$. $\mathrm{Ba} / \mathrm{Ca}$ and $\mathrm{U} / \mathrm{Ca}$ had the most significant correlation between each other $\left(r^{2}=0.47-0.88\right)$, except for within the Ligar Bay 3B and Ligar Bay 4B shells.

No other trace elements showed significant correlations with the others, with the exception of $\mathrm{Al} / \mathrm{Ca}$. Within the Kawhia shell data, $\mathrm{Al} / \mathrm{Ca}$ showed significant correlations with $\mathrm{Mg} / \mathrm{Ca}, \mathrm{Mn} / \mathrm{Ca}, \mathrm{Sr} / \mathrm{Ca}, \mathrm{Ba} / \mathrm{Ca}$ and $\mathrm{U} / \mathrm{Ca}$, with $\mathrm{r}^{2}$ values of $0.58,0.74$, $0.73,0.80$ and 0.65 respectively. The only other significant correlations seen for $\mathrm{Al} / \mathrm{Ca}$ were in the Ligar $6 \mathrm{~B}$ shell data, where $\mathrm{Al} / \mathrm{Ca}$ was weakly correlated with $\mathrm{Mn} / \mathrm{Ca}\left(\mathrm{r}^{2}=\right.$ $0.53)$ and $\mathrm{U} / \mathrm{Ca}\left(\mathrm{r}^{2}=0.58\right)$.

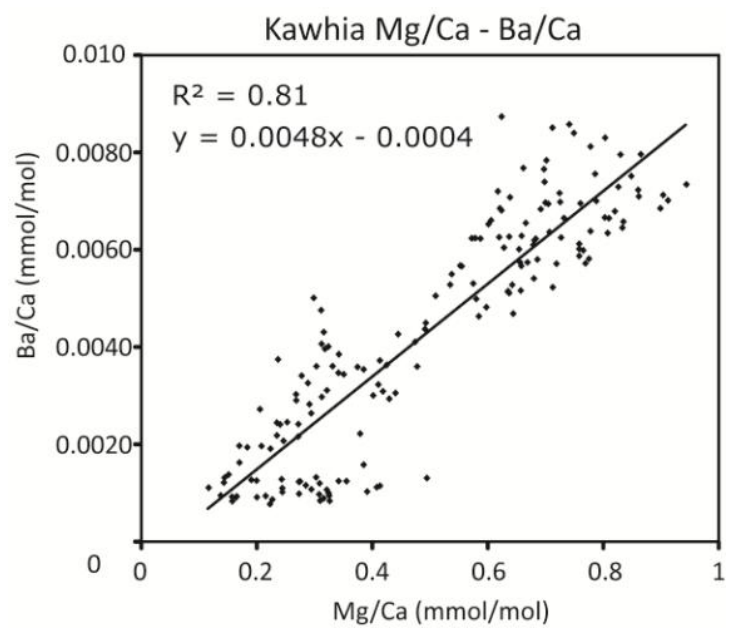

Figure 3.28 Correlation between $\mathrm{Mg} / \mathrm{Ca}$ and $\mathrm{Ba} / \mathrm{Ca}$ ratios from the Kawhia shell.

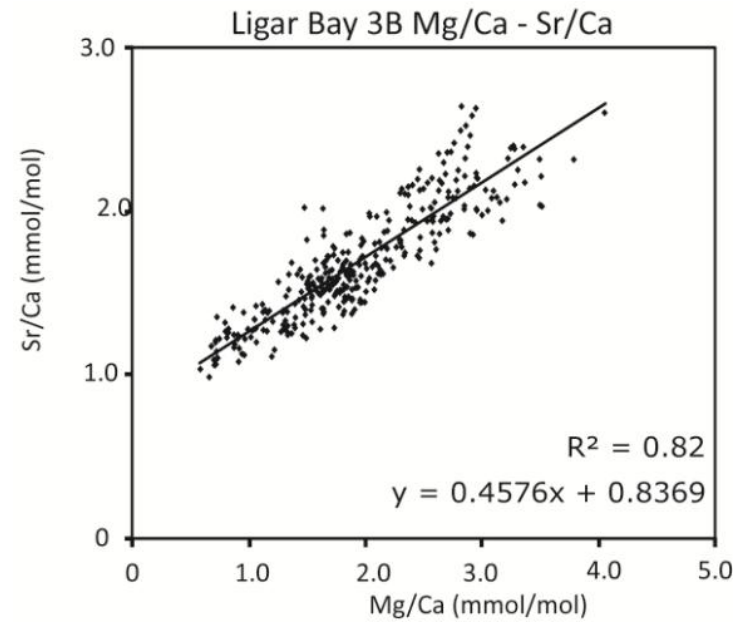

Figure 3.29 Correlation between $\mathrm{Mg} / \mathrm{Ca}$ and $\mathrm{Sr} / \mathrm{Ca}$ ratios from the Ligar Bay 3B shell. 
Trace Element Correlations

\begin{tabular}{|c|c|c|c|c|c|c|c|c|c|c|}
\hline & $\mathrm{Mg}$ & & & & & & & & $\mathrm{Ba}$ & \\
\hline variable & $\mathrm{Mn}$ & & $\mathrm{Sr}$ & & $\mathrm{Ba}$ & & $\mathrm{U}$ & & $\mathrm{U}$ & \\
\hline Shell & $\mathrm{m}$ & $\mathrm{r}^{2}$ & $\mathrm{~m}$ & $\mathrm{r}^{2}$ & $\mathrm{~m}$ & $\mathrm{r}^{2}$ & $\mathrm{~m}$ & $\mathrm{r}^{2}$ & $\mathrm{~m}$ & $\mathrm{r}^{2}$ \\
\hline$\overline{\text { Ligar } 1 B}$ & 0.0026 & 0.74 & 0.48 & 0.65 & 0.0031 & 0.41 & - & - & & \\
\hline Ligar $3 B$ & 0.0025 & 0.66 & 0.46 & 0.80 & & & 0.00010 & 0.82 & & \\
\hline Ligar $4 B$ & 0.0018 & 0.42 & 0.78 & 0.62 & 0.0034 & & 0.00020 & 0.78 & & \\
\hline Ligar $6 B$ & 0.0049 & 0.74 & 0.65 & 0.56 & 0.0067 & 0.83 & 0.00050 & 0.90 & 0.07 & 0.88 \\
\hline $\begin{array}{l}\text { Ligar } \\
\text { estuary }\end{array}$ & & & 0.55 & 0.74 & 0.0017 & 0.42 & 0.00020 & 0.45 & 0.10 & 0.75 \\
\hline Kawhia & 0.042 & 0.81 & 0.92 & 0.77 & 0.0048 & 0.81 & 0.00050 & 0.85 & 0.10 & 0.81 \\
\hline Raglan & 0.15 & 0.87 & 0.95 & 0.84 & 0.0029 & 0.47 & 0.00050 & 0.92 & 0.083 & 0.47 \\
\hline Miranda & 0.17 & 0.73 & 0.97 & 0.86 & 0.0053 & 0.71 & 0.00070 & 0.91 & 0.10 & 0.79 \\
\hline Kaiaua & 0.24 & 0.73 & 0.66 & 0.67 & 0.011 & 0.48 & 0.00080 & 0.72 & 0.046 & 0.54 \\
\hline Manakau & 0.27 & 0.84 & 0.91 & 0.83 & 0.0067 & 0.89 & 0.00060 & 0.82 & 0.085 & 0.88 \\
\hline Pomare & 0.045 & 0.90 & 0.81 & 0.73 & 0.0058 & 0.72 & 0.00050 & 0.80 & 0.063 & 0.64 \\
\hline & $\mathrm{Mn}$ & & & & & & $\mathrm{Sr}$ & & & \\
\hline variable & $\mathrm{Sr}$ & & $\mathrm{Ba}$ & & $\mathrm{U}$ & & $\mathrm{Ba}$ & & $\mathrm{U}$ & \\
\hline Shell & $\mathrm{m}$ & $\mathrm{r}^{2}$ & $\mathrm{~m}$ & $\mathrm{r}^{2}$ & $\mathrm{~m}$ & $\mathrm{r}^{2}$ & $\mathrm{~m}$ & $\mathrm{r}^{2}$ & $\mathrm{~m}$ & $\mathrm{r}^{2}$ \\
\hline Ligar $1 B$ & 160 & 0.63 & & & & & 0.0050 & 0.40 & & \\
\hline Ligar $3 B$ & & & & & 0.033 & 0.66 & & & 0.00020 & 0.79 \\
\hline Ligar $4 B$ & & & & & & & & & 0.00020 & 0.73 \\
\hline Ligar $6 B$ & & & 1.1 & 0.79 & 0.084 & 0.76 & 0.0053 & 0.40 & & \\
\hline $\begin{array}{l}\text { Ligar } \\
\text { estuary }\end{array}$ & & & & & & & & & & \\
\hline Kawhia & 20 & 0.80 & 0.11 & 0.88 & 0.012 & 0.85 & 0.0047 & 0.87 & 0.00050 & 0.79 \\
\hline Raglan & 5.9 & 0.88 & 0.018 & 0.47 & 0.0032 & 0.92 & 0.0029 & 0.51 & 0.00050 & 0.90 \\
\hline Miranda & 4.5 & 0.66 & 0.025 & 0.65 & 0.0031 & 0.75 & 0.0051 & 0.74 & 0.00060 & 0.87 \\
\hline Kaiaua & 3.9 & 0.74 & 0.044 & 0.60 & 0.0032 & 0.82 & 0.0089 & 0.46 & 0.00060 & 0.66 \\
\hline Manakau & 3.1 & 0.72 & 0.023 & 0.89 & 0.0020 & 0.86 & 0.0062 & 0.82 & 0.00050 & 0.69 \\
\hline Pomare & 18 & 0.78 & 0.12 & 0.73 & 0.010 & 0.83 & 0.0065 & 0.81 & 0.00050 & 0.71 \\
\hline
\end{tabular}

Table 3.2 Correlations were calculated between $\mathrm{Mg} / \mathrm{Ca}, \mathrm{Sr} / \mathrm{Ca}, \mathrm{Mn} / \mathrm{Ca}, \mathrm{Ba} / \mathrm{Ca}$ and $\mathrm{U} / \mathrm{Ca}$ across the entire dataset of all individuals of $A$. stutchburyi that were analysed. All correlations that produced a correlation coefficient $\geq 0.40$ are shown in the table, and correlation coefficients and slope (m) values are displayed from the linear regressions made through correlation pairs. 


\subsubsection{Shell averages of trace element/Ca ratios}

Shell averages of TE/Ca ratios were calculated for each shell sample by averaging all the points from one transect across that shell. These averages are shown in Figures 3.30 and 3.31. The length of LA-ICP-MS transects and shell growth rate both varied between all A. stutchburyi analysed. Therefore, it should be noted that these 'averages' could incorporate a degree of error where ontogenetic variations in TE/Ca have been captured to varying degrees between the shells.

With the exception of Ligar Bay $6 \mathrm{~B}(0.56 \mathrm{mmol} / \mathrm{mol})$, the highest average $\mathrm{Mg} / \mathrm{Ca}$ ratios (1.23-1.88 $\mathrm{mmol} / \mathrm{mol})$ were observed in the Ligar Bay shells. Even the highest average $\mathrm{Mg} / \mathrm{Ca}$ ratios are still far below the $\mathrm{Mg} / \mathrm{Ca}$ ratio of seawater $-5.2 \mathrm{mmol} / \mathrm{mol}$ (Elderfield, 2006). The average $\mathrm{Mg} / \mathrm{Ca}$ ratios in A. stutchburyi did not show an increase coinciding with decreasing latitude (and thus increasing average SST) that could imply a positive correlation between $\mathrm{Mg} / \mathrm{Ca}$ and sea temperature. Rather, Ligar Bay is the southernmost location, which would suggest an inverse correlation with SST if there was a relationship at all. The Ligar Estuary shell had an average $\mathrm{Mg} / \mathrm{Ca}$ ratio of 0.61 $\mathrm{mmol} / \mathrm{mol}$ that was more comparable to Ligar bay $6 \mathrm{~B}$ and to the remaining locations that had ratios varying between $0.38-0.60 \mathrm{mmol} / \mathrm{mol}$.

The average $\mathrm{Sr} / \mathrm{Ca}$ A. stutchburyi ratios were $\sim 10$ times lower than that of average modern seawater $\mathrm{Sr} / \mathrm{Ca}-8.9 \mathrm{mmol} / \mathrm{mol}$ (Elderfield, 2006). Average $\mathrm{Sr} / \mathrm{Ca}$ shell ratios also appeared to show no correlation with latitude, with all average ratios observed in a close range of 1.5-2.0 $\mathrm{mmol} / \mathrm{mol}$.

A significant site variation was present in the $\mathrm{Mn} / \mathrm{Ca}$ shell ratios, whereby the four Ligar Bay shells had average $\mathrm{Mn} / \mathrm{Ca}$ ratios $(0.0020-0.0036 \mathrm{mmol} / \mathrm{mol})$ that were an order of magnitude lower than the $\mathrm{Mn} / \mathrm{Ca}$ ratios observed in shells from the remaining locations. Four shells (Raglan, Miranda, Kaiaua and Manakau) had particularly high 

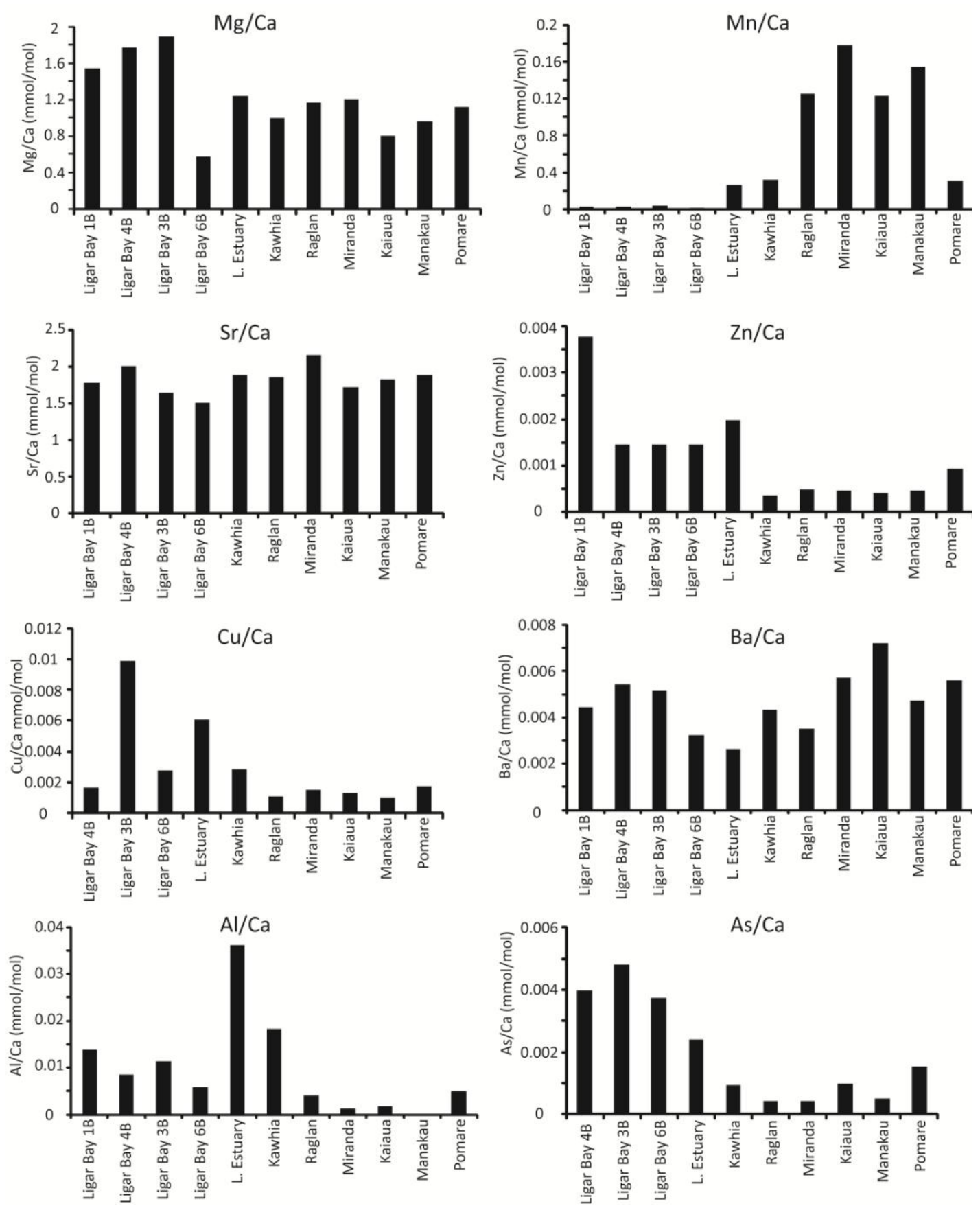

Figure 3.30 Whole-shell averages for $\mathrm{Mg} / \mathrm{Ca}, \mathrm{A} / \mathrm{Ca}, \mathrm{Mn} / \mathrm{Ca}, \mathrm{Cu} / \mathrm{Ca}, \mathrm{Zn} / \mathrm{Ca}$, $\mathrm{As} / \mathrm{Ca}, \mathrm{Sr} / \mathrm{ca}$ and $\mathrm{Ba} / \mathrm{Ca}$. Shell samples, on the horizontal axis are in order of decreasing latitude -i.e. Ligar Bay shells were the most southern site, Pomare shell was from the most northern site. 

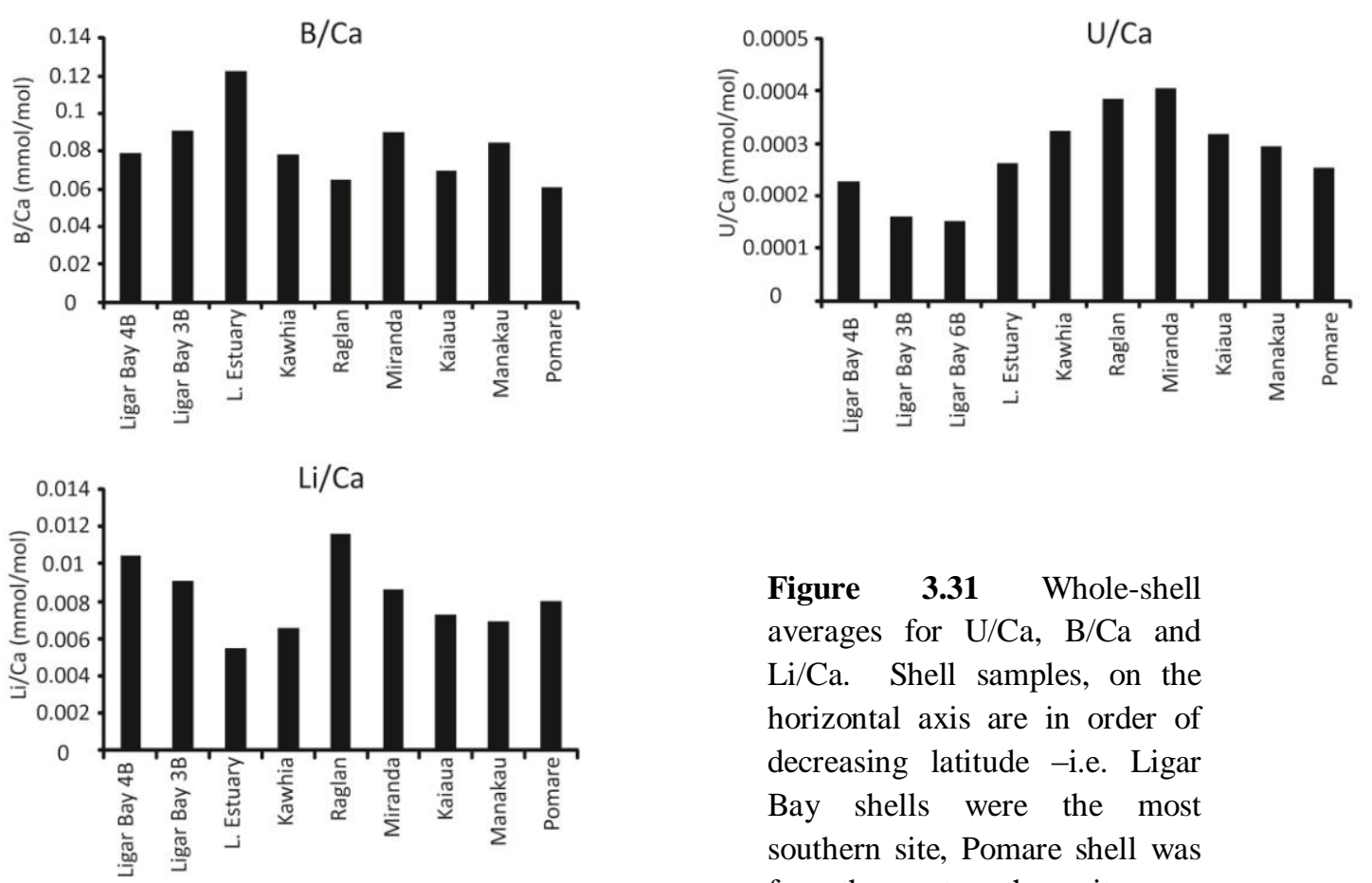

Figure 3.31 Whole-shell
averages for $\mathrm{U} / \mathrm{Ca}, \mathrm{B} / \mathrm{Ca}$ and
$\mathrm{Li} / \mathrm{Ca}$. Shell samples, on the
horizontal axis are in order of
decreasing latitude -i.e. Ligar
Bay shells were the most
southern site, Pomare shell was
from the most northern site.

$\mathrm{Mn} / \mathrm{Ca}$ ratios ranging between $0.12-0.18 \mathrm{mmol} / \mathrm{mol}$. The shells from Kawhia and Pomare displayed $\mathrm{Mn} / \mathrm{Ca}$ ratios -0.032 and $0.031 \mathrm{mmol} / \mathrm{mol}$ respectively approximately three times lower than the shells with the highest $\mathrm{Mn} / \mathrm{Ca}$ ratios. The average $\mathrm{Mn} / \mathrm{Ca}$ ratio of the Ligar Estuary shell $(0.026 \mathrm{mmol} / \mathrm{mol})$, was intermediate between the Kawhia and Pomare shells and the low Mn/Ca Ligar Bay shells.

The TE/Ca ratios of several of the heavy metals $(\mathrm{Zn} / \mathrm{Ca}, \mathrm{Cu} / \mathrm{Ca}, \mathrm{As} / \mathrm{Ca})$ also showed a significant difference between the A. stutchburyi from Ligar Bay and the shells from the other sites. The clearest variation was present in the As/Ca shell ratios in which the average As/Ca ratios of the Ligar Bay shells were an order of magnitude higher than the average ratios of the shells from the other locations; with the exception of the Ligar Estuary shell, which had an average ratio just higher than the non-Ligar Bay shells. Amongst the average $\mathrm{Zn} / \mathrm{Ca}$ shell ratios, all the Ligar Bay shells and the Ligar Estuary shell displayed the highest ratios, with one Ligar Bay shell (1B) having a $\mathrm{Zn} / \mathrm{Ca}$ ratio an order of magnitude higher than all the other samples. Similarly, another Ligar Bay shell 
(3B), and also the Ligar Estuary shell, had $\mathrm{Cu} / \mathrm{Ca}$ ratios that were significantly higher than all other average $\mathrm{Cu} / \mathrm{Ca}$ ratios.

The average $\mathrm{Ba} / \mathrm{Ca}, \mathrm{Li} / \mathrm{Ca}$ and $\mathrm{B} / \mathrm{Ca}$ shell ratios all fall within a reasonably restricted range (0.0026-0.0072, 0.0055-0.012 and 0.061-0.12 mmol/mol, respectively). Average $\mathrm{U} / \mathrm{Ca}$ shell ratios were very low, falling in the range of $0.00015-0.00040 \mathrm{mmol} / \mathrm{mol}$. There was a noticeable site difference in the average $\mathrm{Al} / \mathrm{Ca}$ ratios, as the Ligar Bay shells and Ligar Estuary shell had higher average $\mathrm{Al} / \mathrm{Ca}$ ratios than all the other locations but for the Kawhia shell. 


\subsection{Sediment major elements}

The major element analyses for $\mathrm{Mg}, \mathrm{Mn}, \mathrm{Al}$ and $\mathrm{Ca}$ (Table 3.3) obtained for sediment samples were converted into $\mathrm{Mg} / \mathrm{Ca}, \mathrm{Mn} / \mathrm{Ca}$ and $\mathrm{Al} / \mathrm{Ca}$ ratios in $\mathrm{mmol} / \mathrm{mol}$ (Table 3.4). Comparison of the sediment $\mathrm{TE} / \mathrm{Ca}$ ratios with average shell $\mathrm{TE} / \mathrm{Ca}$ ratios demonstrates there is no correlation between the two (Table 3.4). For example, $\mathrm{Mg} / \mathrm{Ca}$ ratios are highest in Ligar Bay $(1.4 \mathrm{mmol} / \mathrm{mol})$, but the sediment analysed from Ligar Bay has the second lowest $\mathrm{Mg} / \mathrm{Ca}$ ratios (169 mmol/mol).

Table 3.3 XRF major oxide analysis of sediment collected at each site. Reported in weight $\%$.

\begin{tabular}{|c|c|c|c|c|c|c|c|}
\hline Shell & Kawhia & Kaiaua & $\begin{array}{c}\text { Ligar } \\
\text { Bay }\end{array}$ & Manakau & Miranda & Pomare & Raglan \\
\hline $\mathrm{SiO}_{2}$ & 61.7 & 61.8 & 80.6 & 74.0 & 72.4 & 68.0 & 45.0 \\
\hline $\mathrm{Al}_{2} \mathrm{O}_{3}$ & 13.9 & 7.87 & 10.1 & 10.0 & 9.83 & 10.7 & 11.8 \\
\hline $\mathrm{Fe}_{2} \mathrm{O}_{3}$ & 6.21 & 2.52 & 1.17 & 4.60 & 2.92 & 4.32 & 23.2 \\
\hline $\mathrm{CaO}$ & 5.68 & 12.0 & 1.22 & 2.10 & 4.12 & 3.72 & 7.48 \\
\hline $\mathrm{MgO}$ & 3.47 & 0.570 & 0.150 & 1.00 & 0.730 & 0.880 & 4.42 \\
\hline $\mathrm{SO}_{3}$ & $<0.01$ & 0.280 & $<0.0100$ & 0.00 & 0.220 & 0.190 & $<0.0100$ \\
\hline $\mathrm{K}_{2} \mathrm{O}$ & 1.83 & 1.19 & 3.38 & 1.40 & 1.79 & 1.77 & 1.22 \\
\hline $\mathrm{Na}_{2} \mathrm{O}$ & 2.80 & 1.78 & 2.44 & 2.00 & 2.37 & 1.56 & 2.24 \\
\hline $\mathrm{MnO}$ & 0.120 & 0.0400 & 0.0100 & 0.100 & 0.0600 & 0.0300 & 0.310 \\
\hline $\mathrm{TiO}_{2}$ & 0.700 & 0.470 & 0.260 & 0.800 & 0.580 & 0.480 & 2.69 \\
\hline $\mathrm{P}_{2} \mathrm{O}_{5}$ & 0.150 & 0.0600 & 0.0300 & 0.100 & 0.0600 & 0.150 & 0.230 \\
\hline LOI & 3.23 & 11.0 & 0.540 & 3.40 & 4.57 & 8.02 & 0.980 \\
\hline SUM & 99.9 & 99.5 & 99.9 & 100 & 99.6 & 99.9 & 99.6 \\
\hline
\end{tabular}


Table 3.4 Mg/Ca, $\mathrm{Al} / \mathrm{Ca}$ and $\mathrm{Mn} / \mathrm{Ca}$ ratios in $\mathrm{mmol} / \mathrm{mol}$ for sediment samples compared with average $\mathrm{Mg} / \mathrm{Ca}, \mathrm{Al} / \mathrm{Ca}$ and $\mathrm{Mn} / \mathrm{Ca}$ ratios for each shell

\begin{tabular}{|c|c|c|c|c|c|c|c|}
\hline Sediment & Kawhia & Kaiaua & $\begin{array}{c}\text { Ligar } \\
\text { Bay }\end{array}$ & Manakau & Miranda & Pomare & Raglan \\
\hline $\mathrm{mmol} / \mathrm{mol}$ & & & & & & & \\
\hline $\mathrm{Mg} / \mathrm{Ca}$ & 847 & 70 & 169 & 643 & 244 & 329 & 818 \\
\hline $\mathrm{Al} / \mathrm{Ca}$ & 2700 & 724 & 9130 & 5350 & 2620 & 3180 & 1740 \\
\hline $\mathrm{Mn} / \mathrm{Ca}$ & 16.2 & 2.94 & 6.43 & 21.4 & 11 & 5.87 & 32.5 \\
\hline $\begin{array}{c}\text { Average } \\
\text { shell }\end{array}$ & & & & & & & \\
\hline $\mathrm{mmol} / \mathrm{mol}$ & & & & & & & \\
\hline $\mathrm{Mg} / \mathrm{Ca}$ & 0.99 & 0.81 & 1.4 & 0.96 & 1.2 & 1.1 & 1.2 \\
\hline $\mathrm{Al} / \mathrm{Ca}$ & 0.018 & 0.0018 & 0.0099 & 0 & 0.0012 & 0.0049 & 0.0041 \\
\hline $\mathrm{Mn} / \mathrm{Ca}$ & 0.032 & 0.12 & 0.0029 & 0.15 & 0.18 & 0.031 & 0.13 \\
\hline
\end{tabular}




\title{
CHAPTER 4.0 DISCUSSION
}

\subsection{A. stutchburyi sclerochronology}

\author{
4.1.1 Extracting a high-resolution chronology; the limitations of \\ sclerochronology
}

Producing a high-resolution chronology for geochemical data measured in mollusc shells is integral to the purpose of using the shell chemistry as a paleoenvironmental proxy. A. stutchburyi offers the potential to resolve geochemical data up to a sub-daily level, as it deposits micro-increments with a circa-tidal periodicity (McKinnon, 1996). For several species, including the sub-tidal scallop Pecten maximus (Lorrain, 2005), and the long-lived bivalve Arctica islandica (Schöne et al., 2011), counting the number of micro-increments (in cross-section) of the mollusc can provide a high-resolution chronology - down to daily information, depending on sample spacing. However, this method relies on sufficient knowledge of the growth line deposition and also on individual micro-increments being clearly visible - usually under a reflected light microscope, with an etching and dying treatment such as Mutvei's solution (Schöne et al., 2005). For most species, micro-increments/daily growth lines are not clearly visible throughout the shell and thus counting them does not provide an accurate chronology (Schöne, 2008).

A. stutchburyi shells analysed in this study do not have clearly visible daily growth lines throughout their shells; individual micro-increments were only identifiable in some regions in the shells, mostly in the sections that formed while the individuals were young. Several techniques were utilised to try to view the tidal micro-increments in $A$. stutchburyi shells after LA-ICP-MS analysis. Firstly the shells, which were in polished, 
$3.5 \mathrm{~mm}$ epoxy mounts, were viewed at 108x magnification under a reflected light, binocular microscope (Figure 4.1). In each shell some micro-increments were visible at this scale, but in many regions on each shell these were not individually identifiable and could not be counted. Secondly, the shells were viewed at 200x magnification under a reflected light, microscope (Figure 4.2). The higher magnification microscope revealed micro-increments in only two of the 11 shell samples (Ligar Bay 1B and Ligar Bay 4B); most likely as growth structures had been removed by polishing during preparation for LA-ICP-MS analysis. In the two shells where growth structures had not been polished off, the micro-increments were not clear enough across the entire shell to allow these to be counted.

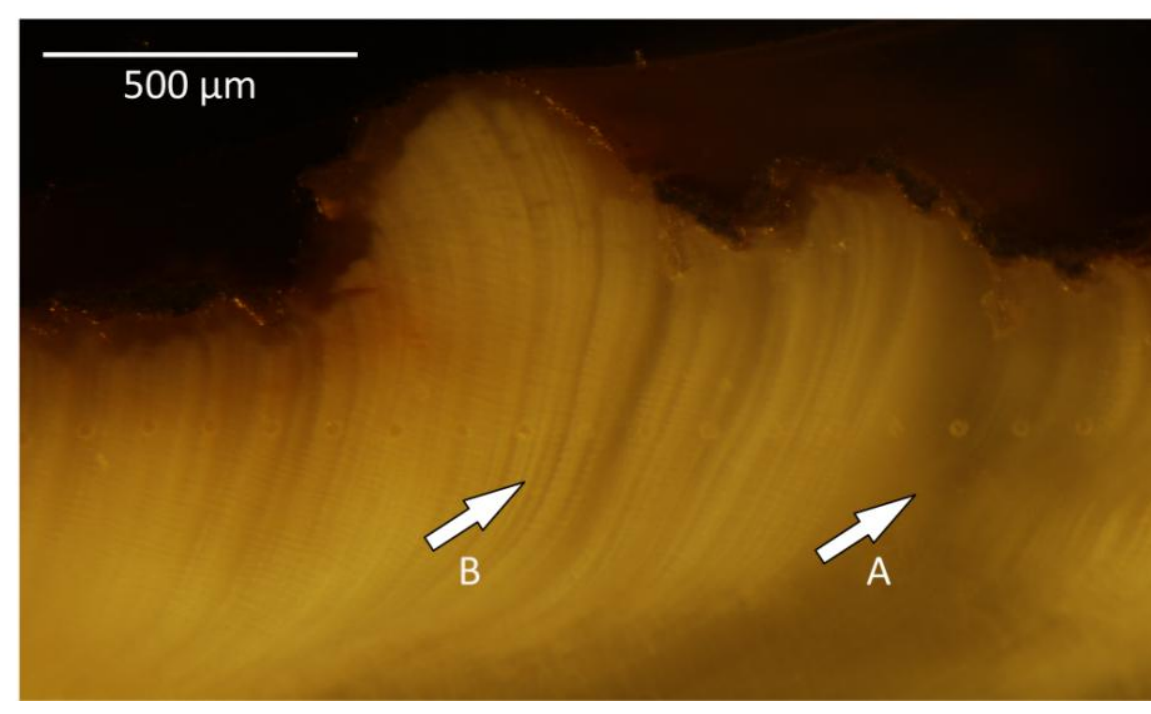

Figure 4.1

Photograph taken of growth patterns on Ligar Bay 1B shell under reflected light at $108 \mathrm{x}$ magnification. A indicates where micro-increments are not seen - coinciding with an annual macro-growth band. $\mathbf{B}$ indicates where micro-increments are

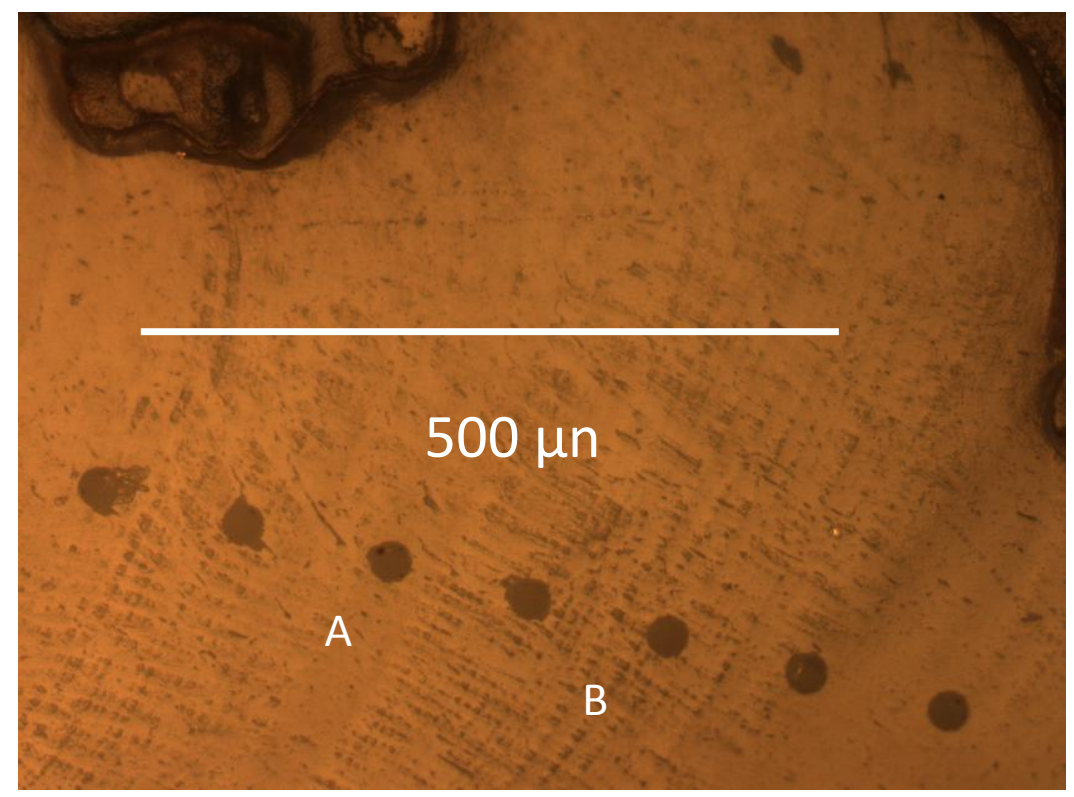
distinguishable.

\section{Figure 4.2}

Photograph taken of growth patterns on Ligar Bay 1B shell under reflected light at a higher magnification 200x. Areas marked with $\mathbf{A}$ indicates where microincrements are not seen. Areas marked with $\mathbf{B}$ indicates where microincrements are distinguishable. 
Etching was subsequently attempted on a mounted sample that had not been analysed

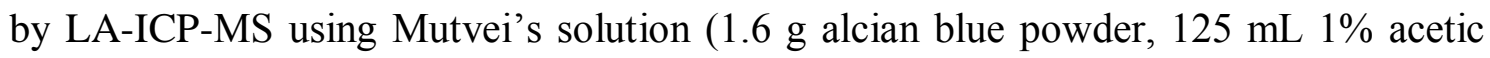

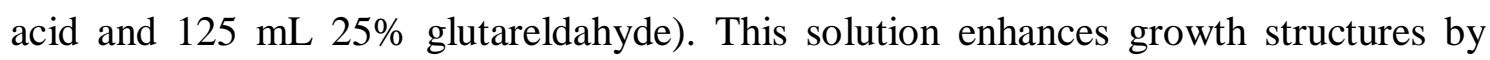
etching out the $\mathrm{CaCO}_{3}$ within the growth increments and staining mucopolysaccharides and glucosamids in the organic growth-lines blue (Schöne et al., 2005; Schöne, 2008). The trial shell used was immersed for $25 \mathrm{~min}$ in the solution under constant stirring at $45{ }^{\circ} \mathrm{C}$, air dried and then viewed under a microscope. It was then immersed under the same conditions for another $25 \mathrm{~min}$ (total of $50 \mathrm{~min}$ ) before being viewed again. The Mutvei's solution etched the shell to varying depths making it difficult to see the shell in clear focus under the higher magnification microscope. Under the lower magnification microscope the etching with Mutvei's solution revealed the microincrements on the shell that had already been visible more clearly, but there were still regions where micro-increments were present but not clearly distinguishable, and regions where there appeared to be no micro-increments at all (Figure 4.3).

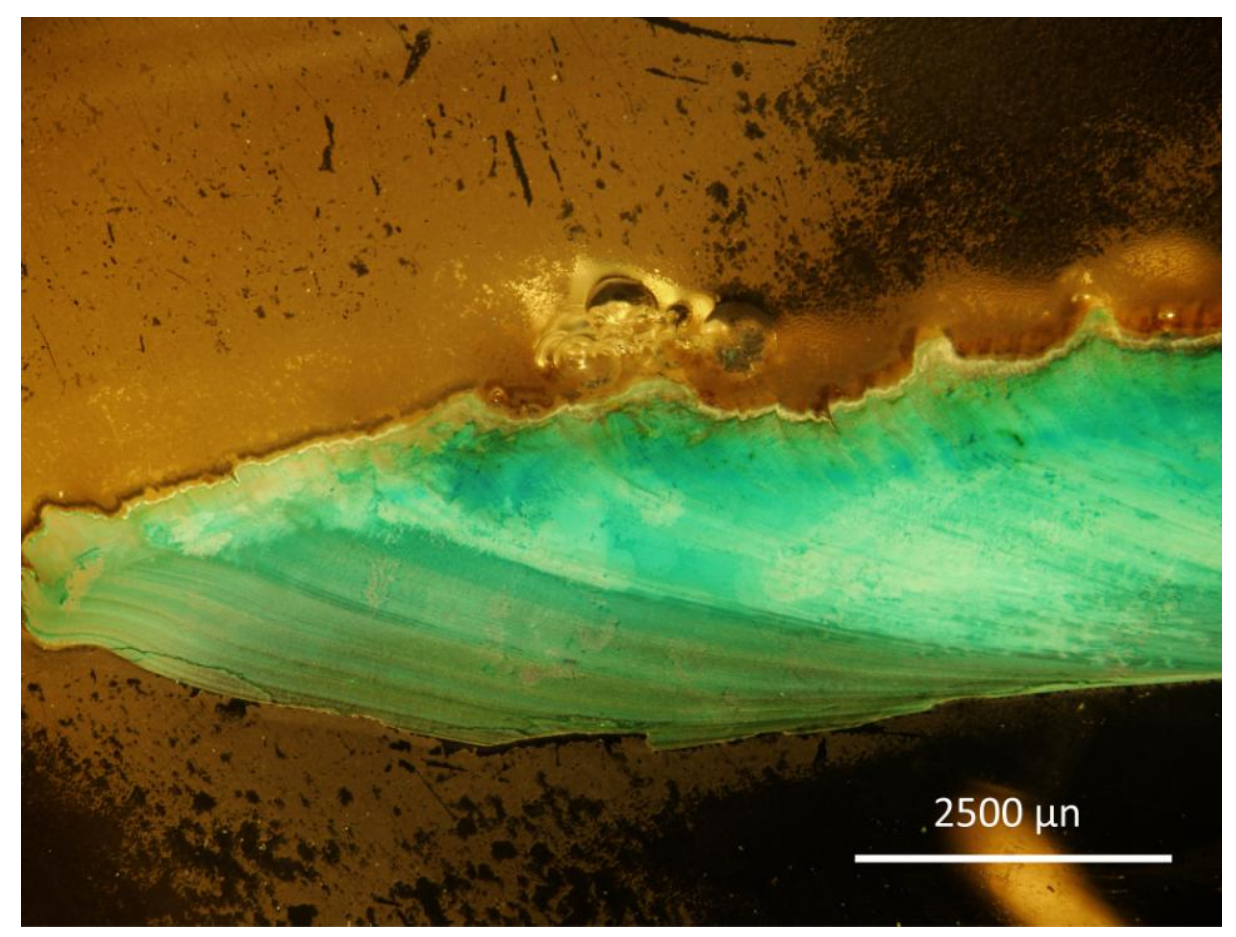

Figure 4.3 Photograph of Ligar Estuary shell after 25 min immersion in Mutvei's solution, taken at 40x magnification with a reflected light microscope. 
The absence of micro-increments in particular regions is not unexpected considering what is known about A. stutchburyi's growth and general observations about bivalves living in the intertidal zone. McKinnon (1996) reported that A. stutchburyi from Port Chalmers in Dunedin did not deposit a micro-increment for each high tide and, during winter, micro-increment addition ceased - although there was variation between the individuals as to the exact months that this spanned. In some individuals, McKinnon (1996) also observed a short break in micro-increment deposition during spawning in January-February. This could explain why regions without micro-increments in $A$. stutchburyi in the current study were often located where annual growth bands were identified (appearing as dark blue regions for the shell emerged in Mutvei's solution), but also why smaller regions without micro-increments were variably observed in the shell macro-increments between annual bands.

However, it is also likely that the timing and amount of micro-increment growth and cessation varied between individuals at different sites, and between individuals from Ligar Bay. Bivalves are sensitive to their environmental conditions (Schöne, 2008). Micro-incremental deposition ceases in response to changes in temperature (some species' temperature-induced growth cessation coincides with spawning), or when conditions outside physiological tolerance occur - such as storm surges. (Schöne, 2008; Brockington and Clarke, 2001). Therefore shells of the same species living in different temperature/environmental conditions are likely to respond to the local conditions and stop depositing micro-increments at different times of year. This has been observed in a number of species, including: A. islandica (Schöne et al., 2005; Schöne 2008), Mercenaria mercenaria (Dalton and Menzel, 1983); and M. donacium (Carré et al., 2005). Ligar Bay A. stutchburyi live in warmer water temperatures than those studied in Dunedin, so it might be expected that winter growth cessation lasts for a shorter time in the Ligar Bay individuals, and perhaps for an even shorter time in the A. stutchburyi 
collected from sites further north (e.g. Pomare in the Bay of Islands). Furthermore, micro-increment growth is affected by the position of individuals in the intertidal zone, as the length of time shells are submerged for during the high tide controls growth time (Schöne, 2008; Evans, 1972; Goodwin et al., 2001; Miyaji et al., 2007). Thus, the individuals higher in the zone may experience cessation during neap tides that the individuals in the low tide zone do not. In conclusion, there are many complicating factors affecting micro-increment deposition that explain why regions with no microincrements were observed in A. stutchburyi in this study, and which could limit the accuracy of a chronology derived from counting individual increments in the clam.

Where individual micro-increments are not identifiable, some studies have instead used fortnightly changes in micro-increments caused by neap and spring tide cycles to construct a chronology (Carré et al., 2005; Carré et al., 2006). Such micro-increment changes have been observed in A. stutchburyi shells (McKinnon, 1996), although these were not visible throughout the A. stutchburyi individuals analysed in this study. Nevertheless counting fortnightly micro-increment bands is also subject to the limitations encountered when counting individual increments, as outlined above. Carré et al. (2005) could not rely on the fortnightly growth increments to date M. donacium shells - their study was integrated with isotopic analyses.

In fact, most $\mathrm{TE} / \mathrm{Ca}$ studies of molluscs have achieved a high-resolution chronology utilising $\delta^{18} \mathrm{O}$ isotope analyses for which it is possible to produce at least a seasonal age model (Carré et al., 2005; Carré et al., 2006; Freitas et al., 2006; Vander Putten et al., 2000; Gillikin et al., 2005). As mollusc shell $\delta^{18} \mathrm{O}$ represents seawater temperature and seawater $\delta^{18} \mathrm{O}, \delta^{18} \mathrm{O}$ records have seasonal temperature and salinity signals, which can be correlated to different times in the year (Vander Putten et al., 2000 and Carré et al., 2005). Further, if seawater $\delta^{18} \mathrm{O}$ and temperature are measured while the analysed 
molluscs are growing, and the $\delta^{18} \mathrm{O}$ relationship has been defined for the species, predicted shell $\delta^{18} \mathrm{O}$ values can be calculated. These can then be compared to measured shell $\delta^{18} \mathrm{O}$ values, and using software such as AnalySeries, specific dates can be assigned to the measured $\delta^{18} \mathrm{O}$ values, and thus trace element records (Freitas et al., 2006). Alternatively, seawater temperatures can be calculated from measured shell $\delta^{18} \mathrm{O}$ and modelled with measured seawater temperatures to derive a timescale (Gillikin et al., 2005). Although these latter two methods clearly cannot be used for fossil mollusc shells, they are an effective way to study the incorporation of trace elements in modern specimens because seasonal variation in the trace element records can be defined, and $\mathrm{TE} / \mathrm{Ca}$ ratios can be directly compared to seawater data (such as temperature, salinity and chlorophyll) on a calendar timescale (Freitas et al., 2006).

\subsubsection{Identifying annual growth bands}

As discussed in Chapter 1.0, previous studies have found A. stutchburyi forms annual growth bands during winter, most likely in July (McKinnon, 1996; Coutts, 1974). In this study annual bands were identified in A. stutchburyi after LA-ICP-MS analysis, using photographs taken of the cross-sectioned shells with a camera mounted on a reflected light microscope at $108 \mathrm{x}$ magnification. The observations outlined by McKinnon (1996) were followed; annual bands are often accompanied by a notch at the shell surface, and usually form a complete dark band from the base of the shell to the surface. However, these characteristics were not always present or clear in all $A$. stutchburyi samples (Figures 4.4-4.5). The region of shell within $\sim 5 \mathrm{~mm}$ of the ventral margin was often complex because there were multiple dark bands (Ligar Bay 3B), or there were no clear micro- or macro-growth patterns and the region was homogeneously dark (Ligar Bay 6B and Kaiaua). Slow-down of growth, permanently, or intermittently, probably caused these patterns near the ventral margin as dark extra-crystalline organic 
material forms when growth ceases and valves are shut (Panella, 1975; Palmer, 1995; Takesue and van Geen, 2004), and A. stutchburyi growth slows significantly with ontogeny (McKinnon, 1996). This trend was observed by Carré et al. (2005) when assigning a chronology to the bivalve $M$. donacium.

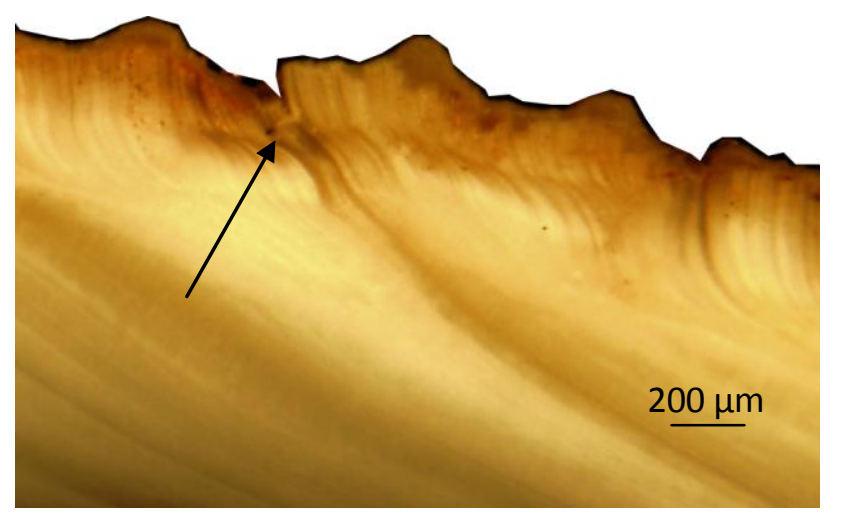

Figure 4.4 Photograph of Ligar 6B showing where an annual growth band is associated with a $\mathrm{V}$ shaped notch in the surface of the shell (black arrow).

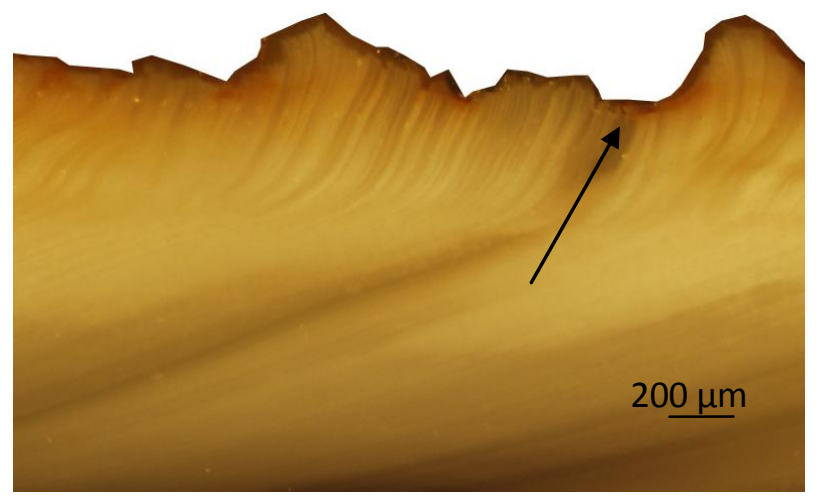

Figure 4.5 Photograph of Ligar 1B showing where an annual growth band is not accompanied by a $\mathrm{V}$ shaped notch (black arrow shows growth band).

Annual bands were identified on the Ligar Bay 1B, Ligar Bay 3B, Ligar Bay 4B, Ligar Bay 6B and the Kaiaua A. stutchburyi samples (see the annual growth bands represented by grey lines on the TE/Ca transects for these shells in Chapter 3). Due to the uncertainties involved in identifying the annual bands only the Ligar Bay 3B and Ligar Bay 4B A. stutchburyi were selected to create a chronology of annual resolution; as their growth bands were clearly identifiable in these individuals, and furthermore, they could be correlated by a common feature in their chemistry. 


\subsubsection{Constructing an annual chronology for Ligar Bay $3 B$ and $4 B$ shells}

The starting point for assigning a common timescale to the Ligar Bay 3B and 4B shells was the 3-point $\mathrm{Ba} / \mathrm{Ca}$ peaks present in both shells' $\mathrm{Ba} / \mathrm{Ca}$ records (Figures 3.7, 3.16 and 3.17; Chapter 3). It was inferred that these peaks were formed at the same time, because of their strong similarity in shape and because the large increase in $\mathrm{Ba} / \mathrm{Ca}$ ratios across the peaks was comparable $(0.039$ and $0.046 \mathrm{mmol} / \mathrm{mol})$. Therefore, the physical location on the shells where the $\mathrm{Ba} / \mathrm{Ca}$ peaks were measured could be fixed in the chronology (Figure 4.6). The method of correlating identical $\mathrm{Ba} / \mathrm{Ca}$ peaks was also used by Takesue et al. (2008) to construct a chronology. In Ligar Bay 3B and Ligar Bay $4 \mathrm{~B}$, the annual growth bands identified in both shells on either side of the $\mathrm{Ba} / \mathrm{Ca}$ peaks were interpreted to have formed during July of the same year. As the $A$. stutchburyi clams were alive when they were collected in April 2008, this date was assigned to the end of the $3 \mathrm{~B}$ and $4 \mathrm{~B}$ records. Both shells had to contain the same number of annual bands between the $\mathrm{Ba} / \mathrm{Ca}$ peak in each shell and the end of each shell, which could not yet contain the winter annual band for 2008 . In $4 \mathrm{~B}$ there were four annual bands that could be confidently identified in this section of the shell. In $3 \mathrm{~B}$ there were only three clearly identifiable bands because at the end of the shell there were a number of dark thin dark bands interspersed with lighter banding. A fourth annual band was inferred to be near the end of Ligar Bay 3B based on the fourth Ligar Bay 4B band, although for the reasons previously stated it could not be pinpointed. Counting backwards from winter 2007, the last possible winter band to form; the $\mathrm{Ba} / \mathrm{Ca}$ peaks were formed between winter 2003 and winter 2004. Before the $\mathrm{Ba} / \mathrm{Ca}$ peaks, annual bands were clear in both shells and could be assigned dates working backwards from winter 2003. 


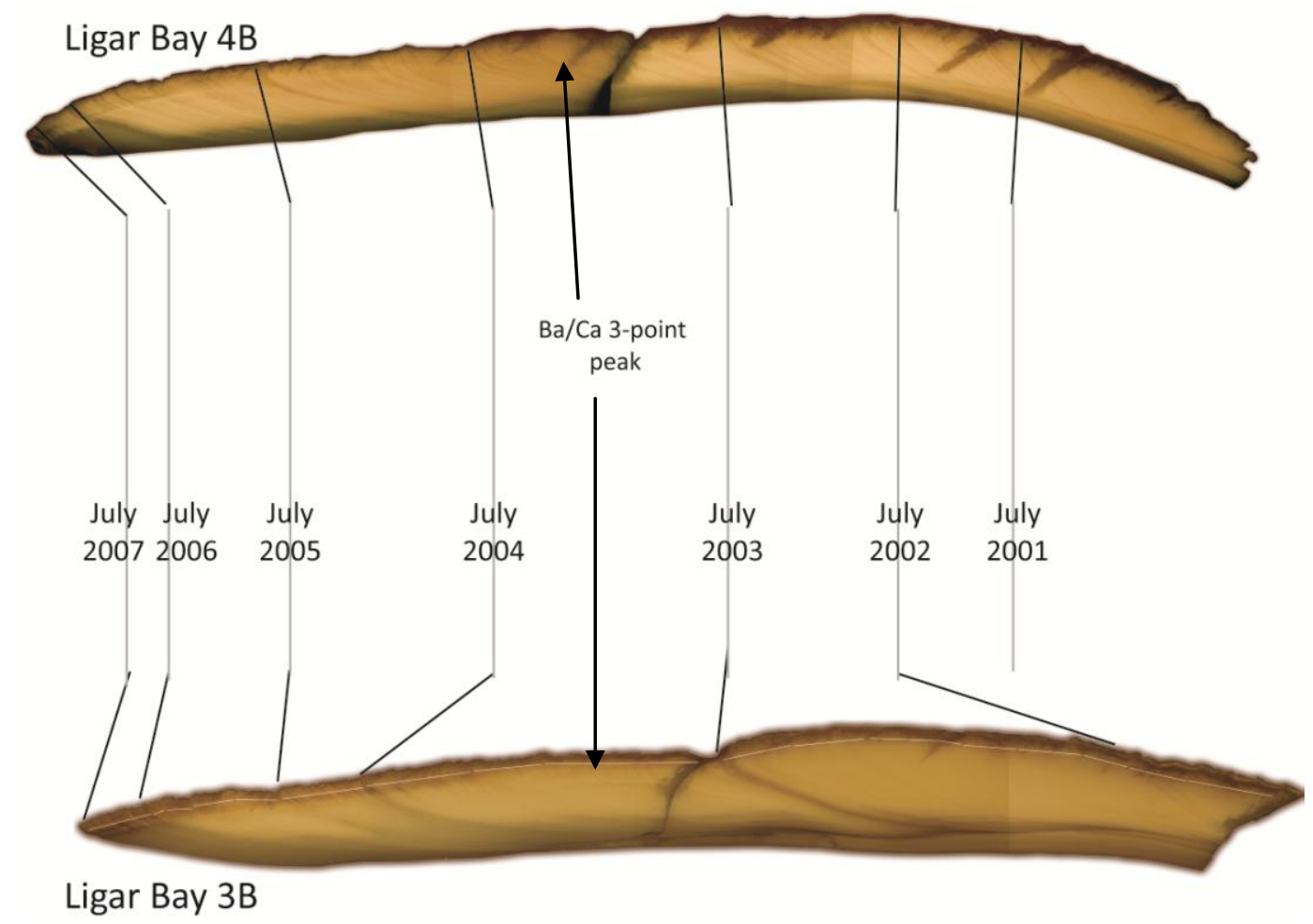

Figure 4.6 Schematic diagram showing the relationship interpreted between annual growth bands on Ligar Bay 3B and Ligar Bay 4B shells. Years from 2007 have been assigned. The annual increment in which the 3-point $\mathrm{Ba} / \mathrm{Ca}$ peaks were found is identified. (Not to scale) 


\subsection{Factors affecting trace element incorporation in $A$. stutchburyi}

\subsubsection{A. stutchburyi growth rate}

Growth rate was calculated in mm per year for 23 annual growth increments in $A$. stutchburyi from Ligar Bay. The amount of annual growth was approximated by the number of laser ablation spots (of known spacing) between annual growth bands. The annual growth measured by this method most likely represents the amount of shell extension in the maximum growth direction, down which the LA-ICP-MS analysis was conducted. This is because laser ablation transects followed the geometry of the shell. Carré et al. (2006) suggested growth rate is better quantified by measuring the width of micro-increments in the crystal growth direction (Figure 4.7) rather than measuring shell extension, because shell extension varies down different growth directions, and also within a growth direction because of shell curvature.

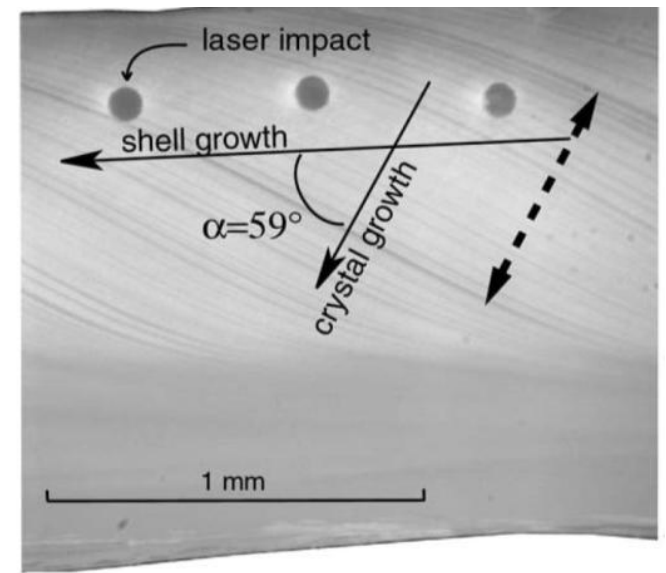

Figure 4.7 Photograph showing the difference between shell growth direction (shell extension) and the crystal growth direction (perpendicular to micro growth lines). Shell extension (growth) was measured in A. stutchburyi by adding the distance between consecutive laser ablation points (labelled 'laser impact' in the photograph). Figure taken from Carré et al. (2006).

However, this requires accurate identification of micro-increments and their deposition periodicity, which was not possible for A. stutchburyi. Other studies have utilised shell extension rate to estimate growth rate (Gillikin et al., 2005; Klein et al., 1996), and it is argued for this study that this method provides a valid estimation of growth rate for correlation with trace element data that is annually resolved. Nevertheless, the 
measurements of annual shell extension potentially include error because of the variations between transects in following the geometry of the shell and because of the human error involved in identifying annual growth bands.

\subsubsection{Growth rate and age correlation with trace element/Ca ratios}

To compare growth rate with trace element/Ca ratios, ratios within annual increments were averaged (Table 4.1). Correlations between average element/Ca ratios and corresponding annual increment growth rate were then made.

Table 4.1 Average shell growth rate $(\mathrm{mm} / \mathrm{yr})$ compared with average trace element/Ca ratios within 23 annual growth increments in A. stutchburyi from Ligar Bay.

\begin{tabular}{|c|c|c|c|c|c|c|c|c|c|c|c|c|c|}
\hline $\begin{array}{l}\text { Shell, and } \\
\text { shell } \\
\text { increment }\end{array}$ & $\begin{array}{c}\text { Years } \\
\text { Before } \\
\text { Death }\end{array}$ & mm/year & $\mathrm{Li} / \mathrm{Ca}$ & $\mathrm{B} / \mathrm{Ca}$ & $\mathrm{Mg} / \mathrm{Ca}$ & $\mathrm{Al} / \mathrm{Ca}$ & $\mathrm{Mn} / \mathrm{Ca}$ & $\mathrm{Cu} / \mathrm{Ca}$ & $\mathrm{Zn} / \mathrm{Ca}$ & $\mathrm{As} / \mathrm{Ca}$ & $\mathrm{Sr} / \mathrm{Ca}$ & $\mathrm{Ba} / \mathrm{Ca}$ & $\mathrm{U} / \mathrm{Ca}$ \\
\hline $\begin{array}{c}1 \mathrm{~B} \\
1\end{array}$ & 0 & 0.60 & 0.017 & 0.10 & 0.75 & 0.00055 & 0.00028 & 0.00096 & 0.00083 & 0.00034 & 1.2 & 0.00096 & 0.000013 \\
\hline 2 & 1 & 1.6 & 0.0078 & 0.095 & 0.82 & 0.0012 & 0.00053 & 0.0012 & 0.0010 & 0.00084 & 1.3 & 0.0015 & 0.000025 \\
\hline 3 & 2 & 3.3 & 0.0092 & 0.10 & 1.0 & 0.0042 & 0.0014 & 0.0016 & 0.0012 & 0.0026 & 1.5 & 0.0035 & 0.000079 \\
\hline 4 & 3 & 5.9 & - & - & 1.7 & 0.012 & 0.0027 & - & 0.0038 & - & 1.8 & 0.0046 & - \\
\hline 5 & 4 & 6.4 & - & - & 2.0 & 0.025 & 0.0040 & - & 0.0061 & - & 2.1 & 0.0059 & - \\
\hline $\begin{array}{c}3 \mathrm{~B} \\
1\end{array}$ & 0 & 0.60 & 0.0096 & 0.11 & 0.73 & 0.0017 & 0.00052 & 0.0041 & 0.00 & 0.00015 & 1.1 & 0.00065 & $4.80 \mathrm{E}-06$ \\
\hline 2 & 1 & 0.70 & 0.0088 & 0.098 & 0.91 & 0.00077 & 0.00076 & 0.0070 & 0.00 & 0.00059 & 1.3 & 0.00066 & 0.000030 \\
\hline 3 & 2 & 2.75 & 0.0079 & 0.091 & 1.8 & 0.0050 & 0.0026 & 0.011 & 0.00032 & 0.0017 & 1.5 & 0.0030 & 0.00012 \\
\hline 4 & 3 & & 0.0074 & 0.097 & 1.3 & 0.0064 & 0.0027 & 0.010 & 0.00093 & & 1.4 & 0.0023 & 0.000096 \\
\hline 5 & 4 & 7.4 & 0.0090 & 0.091 & 1.6 & 0.012 & 0.0034 & 0.015 & 0.0018 & 0.0067 & 1.6 & 0.0073 & 0.00016 \\
\hline 6 & 5 & 8.9 & 0.010 & 0.081 & 2.2 & 0.012 & 0.0044 & 0.0083 & 0.0025 & 0.0055 & 1.8 & 0.0059 & 0.00020 \\
\hline $\begin{array}{c}4 \mathrm{~B} \\
2\end{array}$ & 1 & 3.9 & 0.0082 & 0.073 & 1.5 & 0.0057 & 0.0024 & 0.0015 & 0.00090 & 0.0012 & 1.5 & 0.0022 & 0.00011 \\
\hline 3 & 2 & 4.6 & 0.010 & 0.083 & 1.6 & 0.0081 & 0.0033 & 0.0017 & 0.0015 & 0.0018 & 1.9 & 0.0025 & 0.00017 \\
\hline 4 & 3 & 5.5 & 0.011 & 0.079 & 1.7 & 0.0079 & 0.0027 & 0.0019 & 0.0018 & 0.0067 & 2.2 & 0.012 & 0.00024 \\
\hline 5 & 4 & 3.7 & 0.011 & 0.082 & 2.1 & 0.0081 & 0.0038 & 0.0014 & 0.0011 & 0.0056 & 2.2 & 0.0040 & 0.00029 \\
\hline 6 & 5 & 2.9 & 0.013 & 0.082 & 2.3 & 0.012 & 0.0043 & 0.0014 & 0.0019 & 0.0037 & 2.2 & 0.0054 & 0.00035 \\
\hline $\begin{array}{c}6 \mathrm{~B} \\
2\end{array}$ & 2 & 0.60 & - & - & 0.25 & 0.00061 & 0.00053 & 0.0017 & 0.00045 & 0.00049 & 1.2 & 0.00072 & $2.23 \mathrm{E}-06$ \\
\hline 3 & 3 & 1.9 & - & - & 0.31 & 0.0053 & 0.0011 & 0.0018 & 0.0015 & 0.00093 & 1.4 & 0.0014 & 0.000013 \\
\hline 4 & 4 & 1.9 & - & - & 0.33 & 0.0015 & 0.0010 & 0.0026 & 0.00089 & 0.0042 & 1.5 & 0.0018 & 0.000033 \\
\hline 5 & 5 & 0.7 & - & - & 0.30 & 0.00099 & 0.00021 & 0.0019 & 0 & 0.0016 & 1.2 & 0.0013 & $3.90 \mathrm{E}-07$ \\
\hline 6 & 6 & 1.2 & - & - & 0.31 & 0.0016 & 0.00041 & 0.0022 & 0 & 0.0016 & 1.3 & 0.0020 & $1.88 \mathrm{E}-06$ \\
\hline 7 & 7 & 1.9 & - & - & 0.57 & 0.0063 & 0.0030 & 0.0024 & 0.0011 & 0.0046 & 1.5 & 0.0035 & 0.00015 \\
\hline 8 & 8 & 2.8 & - & - & 0.62 & 0.0050 & 0.0029 & 0.0026 & 0.0020 & 0.012 & 1.5 & 0.0037 & 0.00019 \\
\hline
\end{tabular}


If two annual increments from Ligar Bay $4 \mathrm{~B}$ are excluded, there is significant positive correlation between growth rate and TE/Ca ratios for $\mathrm{Sr} / \mathrm{Ca}\left(\mathrm{r}^{2}=0.68\right), \mathrm{Mg} / \mathrm{Ca}\left(\mathrm{r}^{2}=\right.$ $0.71), \mathrm{Mn} / \mathrm{Ca}\left(\mathrm{r}^{2}=0.72\right), \mathrm{Ba} / \mathrm{Ca}\left(r^{2}=0.60\right), \mathrm{U} / \mathrm{Ca}\left(\mathrm{r}^{2}=0.63\right)$ and $\mathrm{Al} / \mathrm{Ca}\left(\mathrm{r}^{2}=0.65\right)$, for the Ligar Bay individuals combined (Figure 4.8). No other trace elements showed significant correlations, except for $\mathrm{B} / \mathrm{Ca}$, which had a weak, negative correlation with growth rate $\left(r^{2}=0.45\right)$.

When correlations were made separately for each shell, the strength of the correlation improved in some cases (Figure 4.9). In particular, for $\mathrm{Sr} / \mathrm{Ca}$ the correlation with growth rate for each individual Ligar Bay shell was high - with correlation coefficient values of 0.92, 0.88 and 0.85 for Ligar Bay 1B, Ligar Bay 3B and Ligar Bay 6B, respectively. The slopes of the linear regressions for the Sr/Ca-growth rate correlations were variable between the shells (for example 0.16 compared to 0.065 ). Other than $\mathrm{Sr} / \mathrm{Ca}$, the strength of $\mathrm{TE} / \mathrm{Ca}$ ratio correlation with growth rate was variable between shells. Ligar Bay $1 \mathrm{~B}$ and Ligar Bay 3B both individually had stronger correlations between growth rate and $\mathrm{Mg} / \mathrm{Ca}, \mathrm{Mn} / \mathrm{Ca}, \mathrm{Ba} / \mathrm{Ca}$ and $\mathrm{U} / \mathrm{Ca}$, whereas Ligar Bay $6 \mathrm{~B}$ had a lower individual correlation for $\mathrm{Mn} / \mathrm{Ca}, \mathrm{Mg} / \mathrm{Ca}$ and $\mathrm{U} / \mathrm{Ca}$, and had only a marginally higher individual correlation for $\mathrm{Ba} / \mathrm{Ca}$.

The growth rate results indicate that shell growth rate (here quantified by extension rate), significantly affects trace element incorporation. For $\mathrm{Mg} / \mathrm{Ca}, \mathrm{Sr} / \mathrm{Ca}, \mathrm{Mn} / \mathrm{Ca}, \mathrm{U} / \mathrm{Ca}$, $\mathrm{Ba} / \mathrm{Ca}$ and $\mathrm{Al} / \mathrm{Ca}$ the correlation with growth rate is positive; faster growing increments have higher average $\mathrm{TE} / \mathrm{Ca}$ ratios. $\mathrm{Sr} / \mathrm{Ca}$ ratios were the most dominated by growth rate, as individually the Ligar Bay shells all showed a very strong $\left(r^{2} \geq 0.85\right)$ correlation between $\mathrm{Sr} / \mathrm{Ca}$ and growth rate. However, the exact relationship and sensitivity to growth rate is specific to individuals based on the variability in correlation strength and 
linear regression slope value between the Ligar Bay shells. Schöne et al. (2011) found that in fast growing annual increments of Arctica islandica TE/Ca ratios
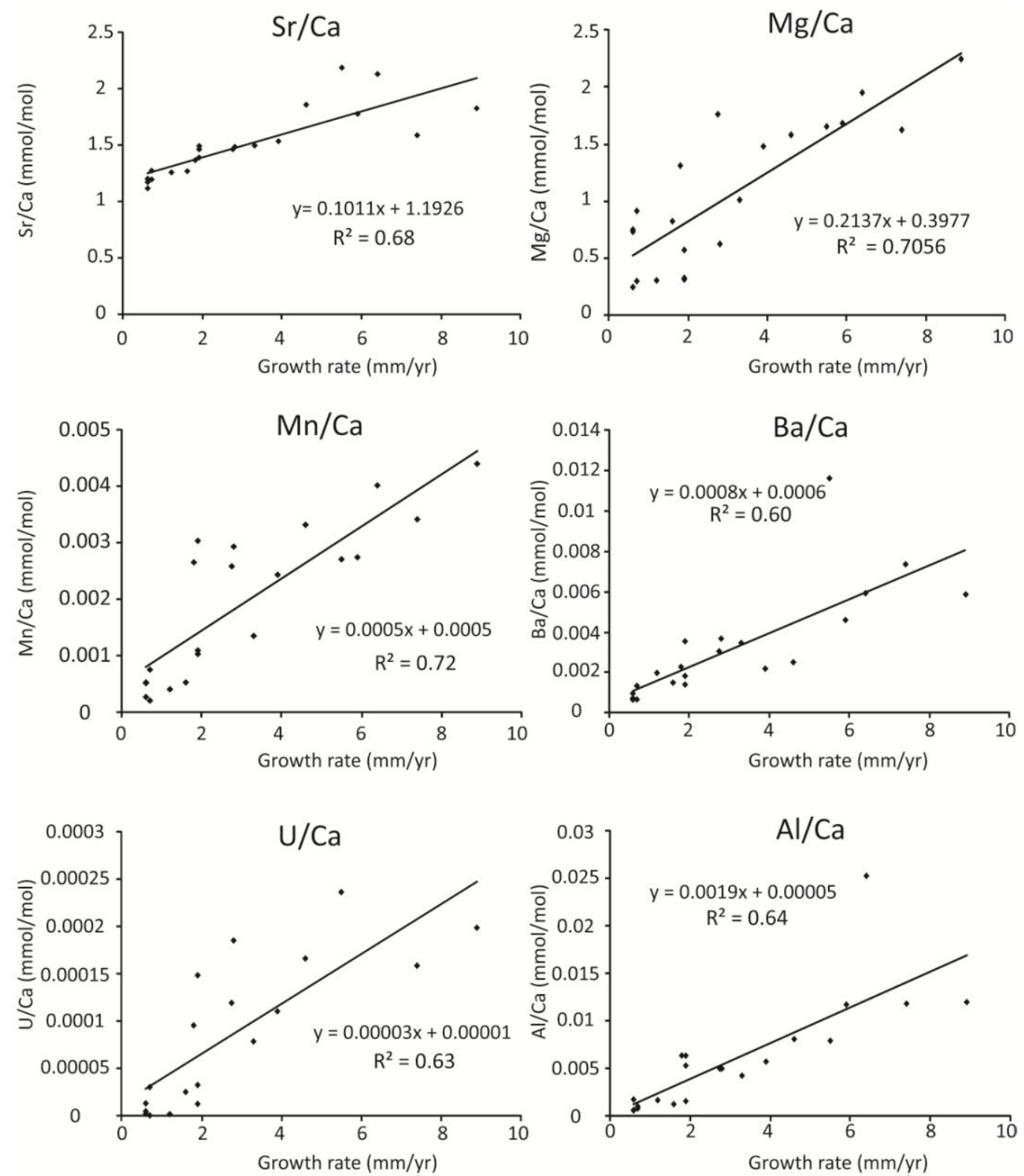

Figure 4.8 Correlations between growth rate (mm/year) for growth increments in Ligar Bay shells and average TE/Ca ratios in those same increments.

were weakly positively correlated to growth rate, but in slow growing increments (below 30-200 $\mu \mathrm{m}$ per year) there was a strong inverse correlation. For A. stutchburyi, shells with the highest growth rates (Ligar Bay 1B and Ligar Bay 3B) had the best correlations with growth rate, whereas Ligar Bay 6B, which had lower growth rates, had 

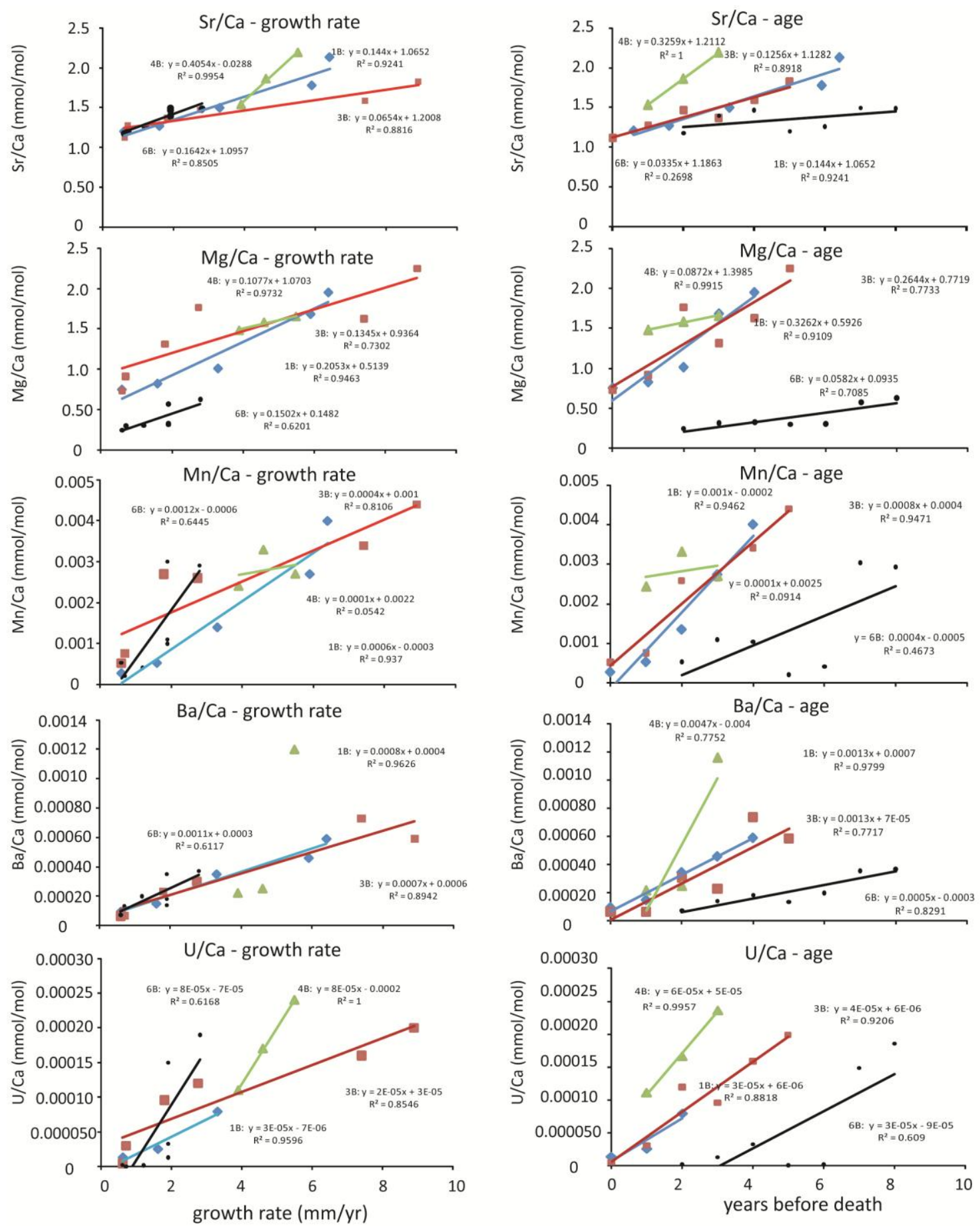

$1 \mathrm{~B} \quad 3 \mathrm{~B}$

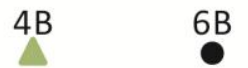

Linear (1B) Linear (3B) Linear (4B) Linear (6B)

Figure 4.9 Graphs on the left-hand side show growth rate correlations with $\mathrm{Mg} / \mathrm{Ca}, \mathrm{Sr} / \mathrm{Ca}$, $\mathrm{M} / \mathrm{Ca}, \mathrm{Ba} / \mathrm{Ca}$ and $\mathrm{U} / \mathrm{Ca}$ for individual Ligar Bay shells. Graphs on the right-hand side show age (in years before death) correlations with $\mathrm{Mg} / \mathrm{Ca}, \mathrm{Sr} / \mathrm{Ca}, \mathrm{M} / \mathrm{Ca}, \mathrm{Ba} / \mathrm{Ca}$ and $\mathrm{U} / \mathrm{Ca}$ for individual Ligar Bay shells. Linear regression equations and $\mathrm{r}^{2}$ values of correlations are displayed on graphs. 
An ontogenetic decrease in TE/Ca ratios was observed in the records from Ligar Bay $A$. stutchburyi. Average TE/Ca ratios for annual increments were compared to the age (measured in years before death) of the increments in order to quantify this effect (Figure 4.9). There was a significant positive correlation between years before death and average $\mathrm{TE} / \mathrm{Ca}$ ratios for $\mathrm{Mg} / \mathrm{Ca}, \mathrm{Sr} / \mathrm{Ca}, \mathrm{Mn} / \mathrm{Ca}, \mathrm{Ba} / \mathrm{Ca}$ and $\mathrm{U} / \mathrm{Ca}$. As with growth rate correlation, Ligar Bay $6 \mathrm{~B}$ had lower correlation coefficients $\left(\mathrm{r}^{2}<0.7\right)$ between age and $\mathrm{U} / \mathrm{Ca}, \mathrm{Mn} / \mathrm{Ca}$ and $\mathrm{Sr} / \mathrm{Ca}$. This may indicate that in slower-growing A. stutchburyi individuals biological influences on element partitioning are weaker, and secondary

effects such as temperature and ocean chemistry have more influence. Alternatively, the effect could be due to errors in identifying ages for annual bands in Ligar Bay 6B, which was particularly difficult in the youngest regions of the shell because of its slow growth rate. The overall strong correlations found between TE/Ca ratios and age is consistent with the growth rate results, as $A$. stutchburyi growth rate decreases with age.

\subsection{3 $\mathrm{Sr} / \mathrm{Ca}$ and $\mathrm{Mg} / \mathrm{Ca}$ ratios}

$\mathrm{Mg} / \mathrm{Ca}$ ratios in all $A$. stutchburyi shells analysed ranged between 0.14 and 4.05 $\mathrm{mmol} / \mathrm{mol}$, and $\mathrm{Sr} / \mathrm{Ca}$ ratios between 0.98 and $3.46 \mathrm{mmol} / \mathrm{mol}$. These ratios were significantly lower than the seawater ratios of $\mathrm{Mg} / \mathrm{Ca}-5.2 \mathrm{mmol} / \mathrm{mol}$, and $\mathrm{Sr} / \mathrm{Ca}-8.9$ mmol/mol (Elderfield, 2006), which confirms that physiological, metabolic or environmental factors control the incorporation of these elements into the crystal lattice. For the Ligar Bay shells, which were collected from an open beach environment, it is unlikely that the $\mathrm{Mg} / \mathrm{Ca}$ and $\mathrm{Sr} / \mathrm{Ca}$ ratio variations were caused by variations in conservative seawater ratios. Further, for the remaining shells, which were collected from estuarine and mud-flat environments, Dodd and Crisp (1982) have shown that $\mathrm{Mg} / \mathrm{Ca}$ and $\mathrm{Sr} / \mathrm{Ca}$ ratios in estuarine waters only vary from ocean ratios at salinities below 10\%. A. stutchburyi are very sensitive to salinity; Marsden (2004) found that the 
clams only survived 6 weeks in salinities down to 7\%o with high phytoplankton availability. At $14 \%$ salinity with low food availability, clams survived only 4 weeks. Therefore, it seems unlikely that A. stutchburyi were collected from estuaries and mud flats below the $10 \%$ salinity threshold because populations would not be sustained in that salinity environment.

The strong positive correlation with growth rate and strong negative correlation with ontogenetic age for both trace elements indicate that metabolic and physiological processes connected to the rate of mineralization and its decrease with age are the most dominant control on $\mathrm{Mg} / \mathrm{Ca}$ and $\mathrm{Sr} / \mathrm{Ca}$ ratios in A. stutchburyi. However, as growth rate and age correlations were not perfect it is likely that other influences affect the incorporation of $\mathrm{Mg}^{2+}$ and $\mathrm{Sr}^{2+}$, and have some signal in the $\mathrm{Mg} / \mathrm{Ca}$ and $\mathrm{Sr} / \mathrm{Ca}$ records.

For the Ligar Bay 3B and Ligar Bay 4B shells that an annual chronology was constructed for, $\mathrm{Mg} / \mathrm{Ca}$ and $\mathrm{Sr} / \mathrm{Ca}$ ratios were compared to a satellite sea surface temperature (SST) record for Golden Bay, the larger, open bay in which Ligar Bay is located. $\mathrm{Mg} / \mathrm{Ca}$ and $\mathrm{Sr} / \mathrm{Ca}$ ratios were evenly spread between annual growth points (set to July of each year when growth bands were formed), which assumes a constant growth rate within increments. Calendar months are included on the time series graphs; although as discussed in section 4.1 above, data points were not resolved to this level and the months are extrapolated from the annual chronology.

The comparison of the Ligar Bay 4B and Ligar Bay 3B Mg/Ca and Sr/Ca records with SST (Figures 4.10 and 4.11, respectively) did not reveal an obvious relationship between the TE/Ca ratios and temperature. There was occasionally a visible positive correlation between $\mathrm{SST}$ and $\mathrm{Mg} / \mathrm{Ca}$ and $\mathrm{Sr} / \mathrm{Ca}$ ratios in the records between JulyAugust when the ratios and SST each decreased; twice in Ligar Bay 4B, and four times in Ligar Bay 3B years (shown on Figures 4.9 and 4.10 by vertical dashed lines). Also, 
between July 2005 and July $2006 \mathrm{Mg} / \mathrm{Ca}$ in the Ligar Bay 3B record appeared to show a seasonal pattern mimicking the SST record. Apart from these observations the Ligar Bay 3B and Ligar Bay 4B $\mathrm{Mg} / \mathrm{Ca}$ and $\mathrm{Sr} / \mathrm{Ca}$ records did not show seasonal variations with SST, and were dominated by the ontogenetic decrease in TE/Ca ratios.

\section{Ligar Bay 4B}

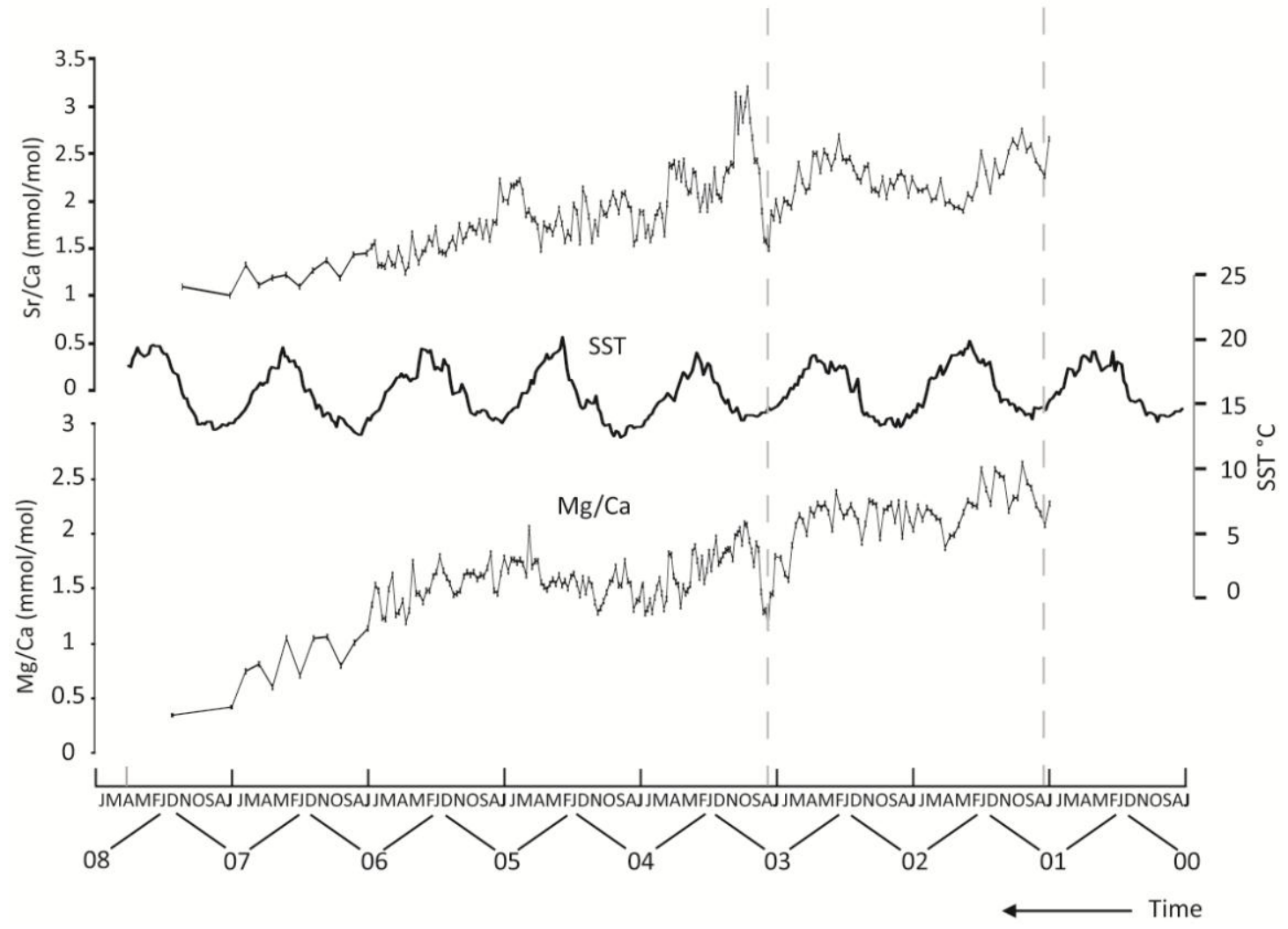

Figure 4.10 $\mathrm{Mg} / \mathrm{Ca}(\mathrm{mmol} / \mathrm{mol})$ and $\mathrm{Sr} / \mathrm{Ca}(\mathrm{mmol} / \mathrm{mol})$ records from Ligar Bay 4B plotted against time (running right to left). The plot assumes a constant growth rate between annual increments (from July to July - marked as black lines on the timescale). Years (2000-2008) are indicated by 00-08. Grey lines indicate where potential positive correlations exist between SST, $\mathrm{Mg} / \mathrm{Ca}$ and $\mathrm{Sr} / \mathrm{Ca}$. 


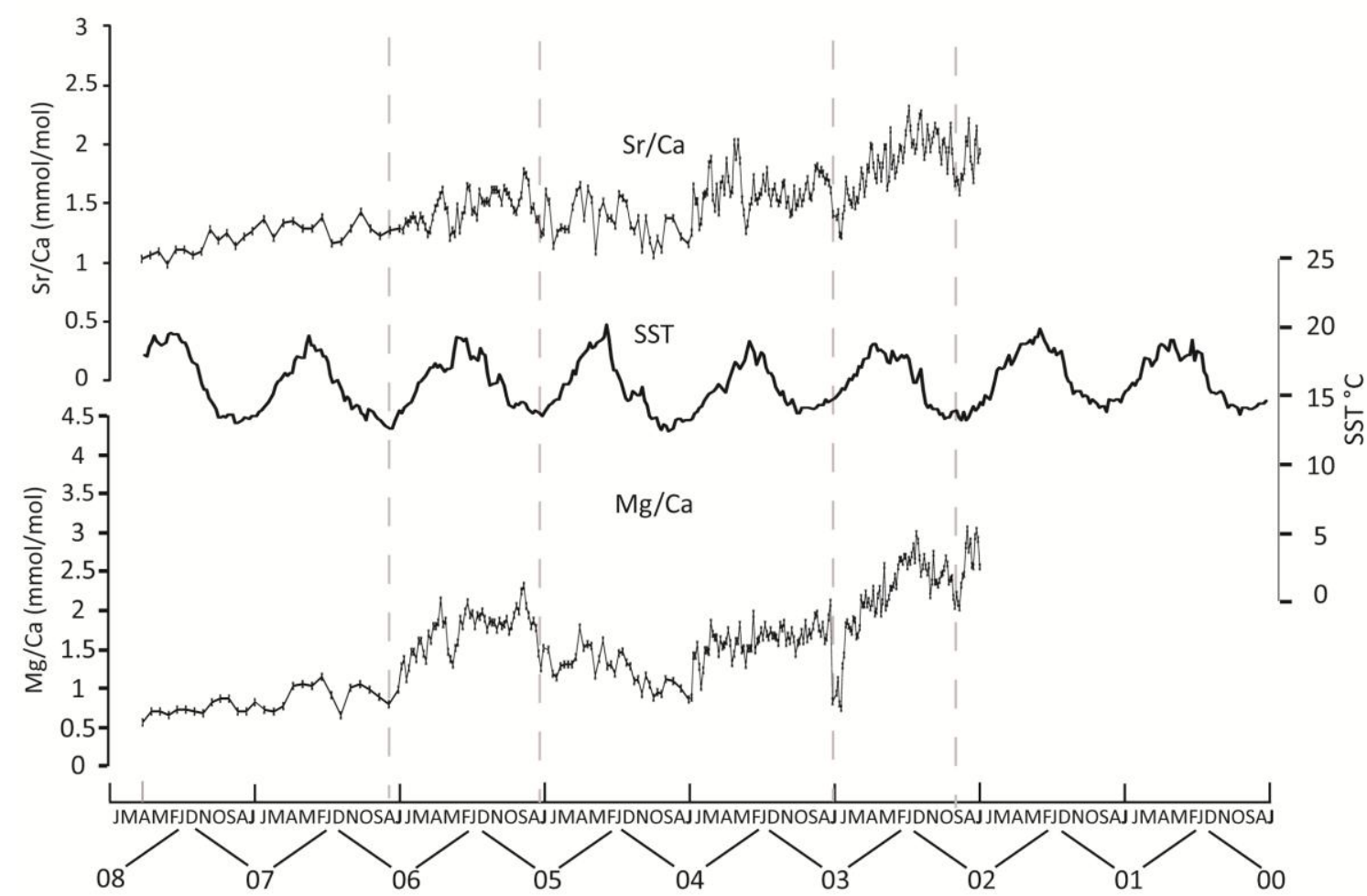

Figure 4.11 $\mathrm{Mg} / \mathrm{Ca}(\mathrm{mmol} / \mathrm{mol})$ and $\mathrm{Sr} / \mathrm{Ca}(\mathrm{mmol} / \mathrm{mol})$ records from Ligar Bay 3B plotted against time (running right to left). The plot assumes a constant growth rate between annual increments (from July to July - marked as black lines on the timescale). Years (2000-2008) are indicated by 00-08. Grey lines indicate where potential positive correlations exist between $\mathrm{SST}, \mathrm{Mg} / \mathrm{Ca}$ and $\mathrm{Sr} / \mathrm{Ca}$.

Schöne et al. (2011) attempted to mathematically eliminate the growth rate and ontogenetic effect on $\mathrm{Mg} / \mathrm{Ca}$ and $\mathrm{Sr} / \mathrm{Ca}$ records to test whether the remaining signal was correlated to SST. This consisted of detrending the data by dividing actual TE/Ca ratios by 'predicted' TE/Ca ratios; calculated from the linear regressions made between TE/Ca ratios and growth rate and ontogenetic age. The resulting values were then standardised: the mean of the values was subtracted from each value and they were then divided by the standard deviation of the actual/'predicted' values. This produced dimensionless measures of TE/Ca ratios. When compared to SST the detrended $\mathrm{Mg} / \mathrm{Ca}$ and $\mathrm{Sr} / \mathrm{Ca}$ data showed an inverse correlation to temperature $\left(\mathrm{Sr} / \mathrm{Ca} \mathrm{r}^{2}=-0.64\right.$ and $\left.\mathrm{Mg} / \mathrm{Ca} \mathrm{r}^{2}=-0.52\right)$, whereas the original TE/Ca records had shown no correlation. This method was applied 
to $\mathrm{Mg} / \mathrm{Ca}$ and $\mathrm{Sr} / \mathrm{Ca}$ ratios in the Ligar Bay $3 \mathrm{~B}$ record. Ages (measured in days before death) were calculated for each ratio by extrapolating between the annual data points. The results for $\mathrm{Sr} / \mathrm{Ca}$ are shown below in Figure 4.12, and demonstrate that age detrending removes the ontogenetic decrease from the records, but does not reveal any new patterns of variation, which remains the same as in the original $\mathrm{Sr} / \mathrm{Ca}$ record. This was also the case for $\mathrm{Mg} / \mathrm{Ca}$ ratios, not shown.
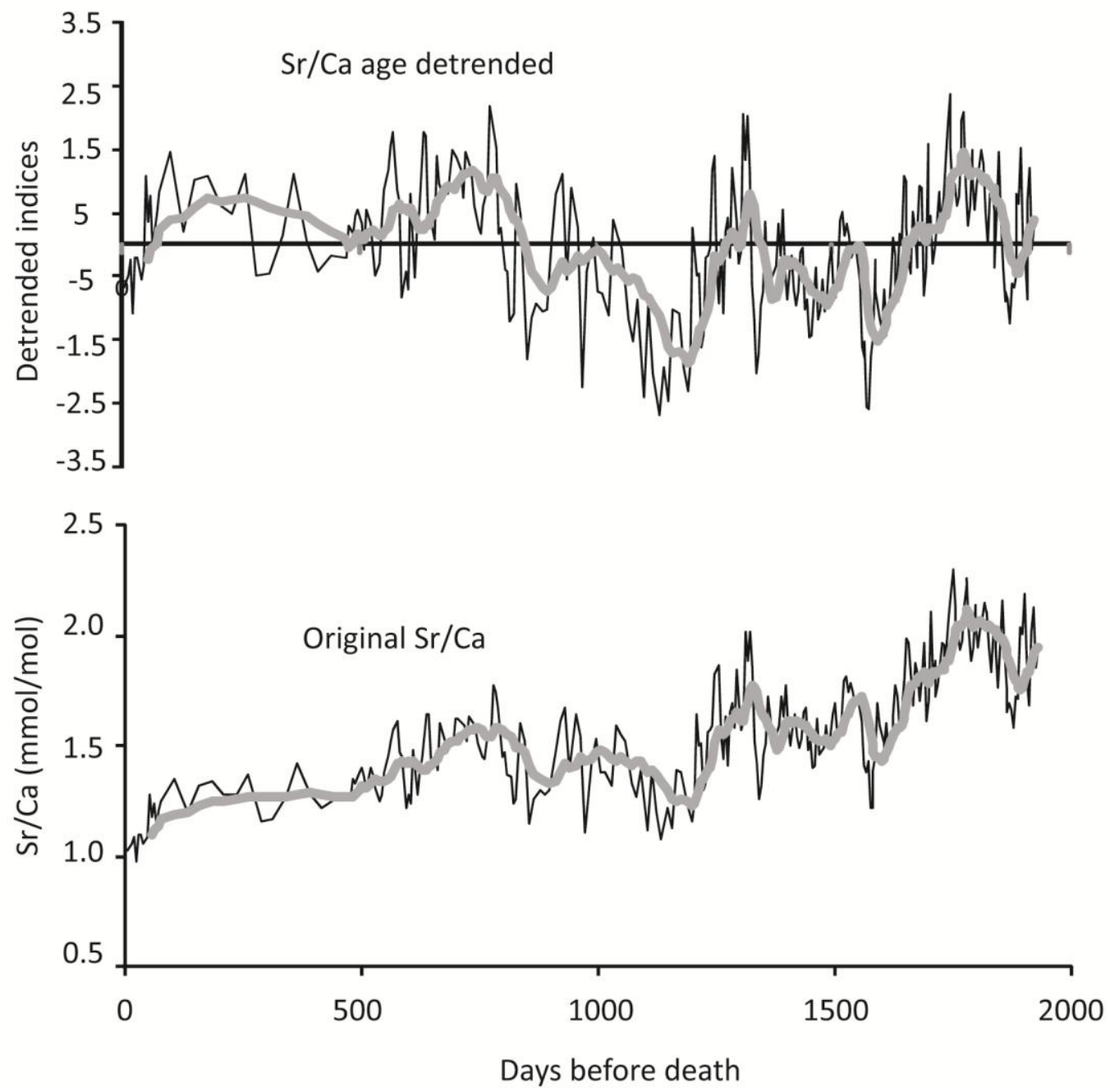

Figure 4.12 Black lines: Comparison of age-detrended $\mathrm{Sr} / \mathrm{Ca}$ indices to original $\mathrm{Sr} / \mathrm{Ca}$ ratios (mmol/mol) from Ligar Bay 3B. All data are plotted against the age of the shell (days before death). Grey Lines: 10 point moving average of age detrended and original Sr/Ca data. 
The effect of growth rate could not be eliminated from the Ligar Bay 3B and Ligar Bay 4B Sr/Ca and $\mathrm{Mg} / \mathrm{Ca}$ records following the method by Schöne et al. (2011) because there was no precise growth rate data available for all the ratios. Therefore, to remove growth rate, $\mathrm{Mg} / \mathrm{Ca}$ records from Ligar Bay shells were normalised to $\mathrm{Sr} / \mathrm{Ca}$, on the basis that $\mathrm{Sr} / \mathrm{Ca}$ was most highly correlated to growth rate (see section 4.2.1 above). This was done by subtracting the actual $\mathrm{Mg} / \mathrm{Ca}$ ratios from predicted $\mathrm{Mg} / \mathrm{Ca}$ ratios which were calculated from linear regression of the $\mathrm{Mg} / \mathrm{Ca}$ and $\mathrm{Sr} / \mathrm{Ca}$ data. Plotted in time series, the Ligar Bay 4B normalised $\mathrm{Mg} / \mathrm{Ca}$ record appeared visually to positively correlate with SST in at least two annual increments (Figures 4.14-4.15). Ligar Bay 3B, did not show any visual correlation (Figure 4.13).

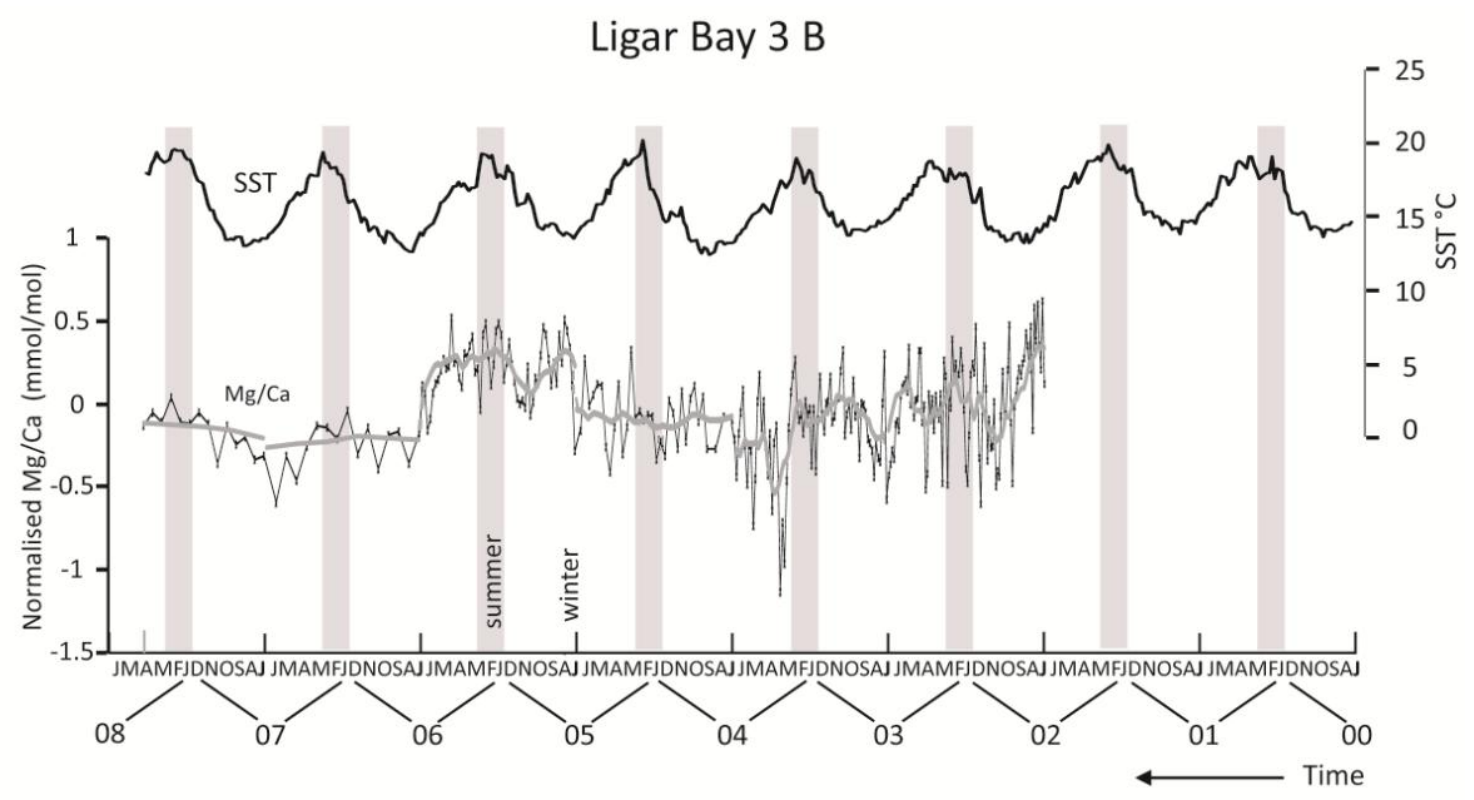

Figure 4.13 Mg/Ca ratios normalised to $\mathrm{Sr} / \mathrm{Ca}$ from Ligar Bay 3B plotted against time (running right to left). The plot assumes a constant growth rate between annual increments (from July to July - marked as black lines on the timescale). Years (2000-2008) are indicated by 00-08. 


\section{Ligar Bay 4B}

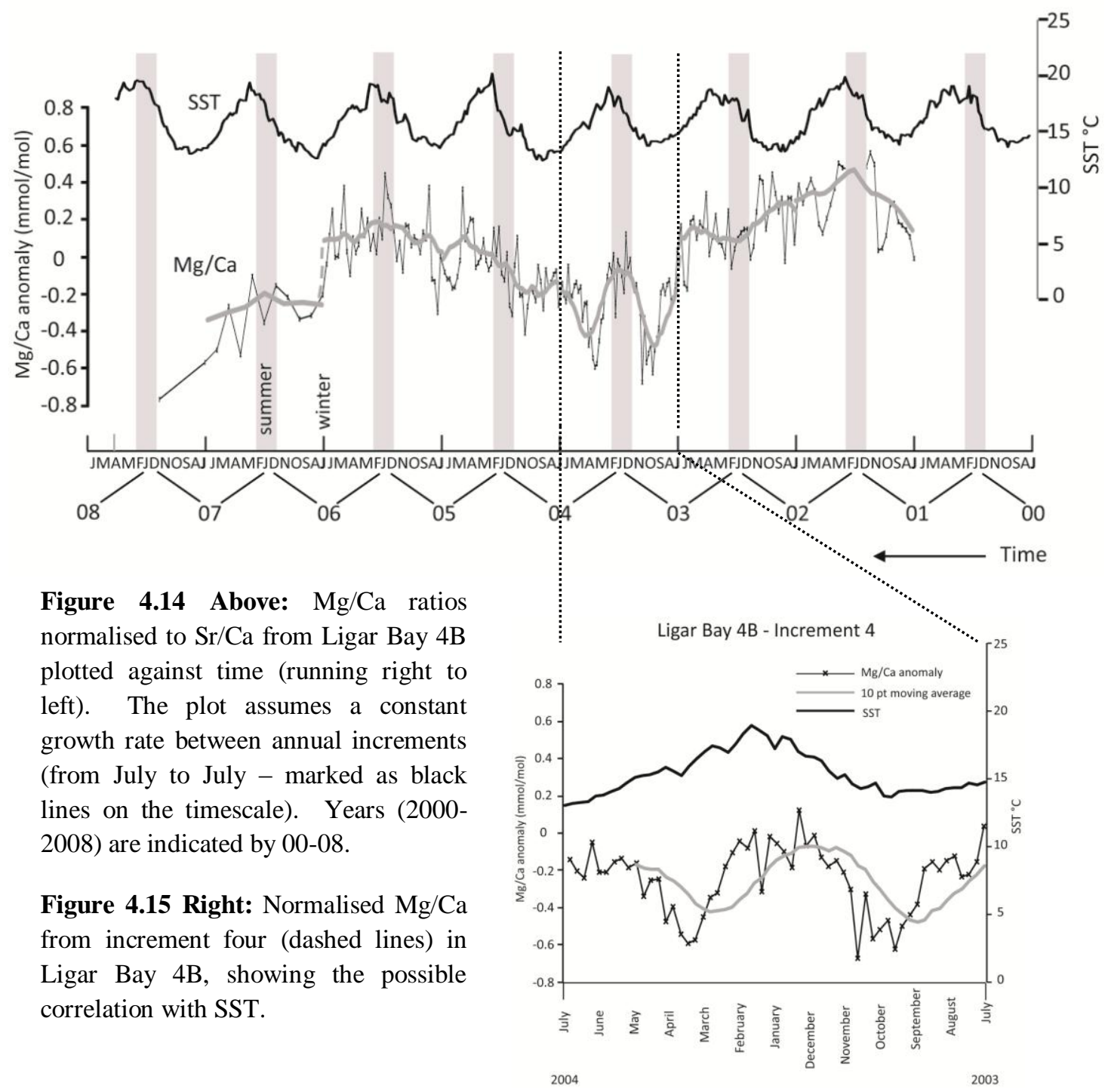

In particular, $\mathrm{Mg} / \mathrm{Ca}$ ratios in increment four (Figure 4.15) seemed to follow SST.

However, matching temperatures with normalised ratios only yielded a correlation coefficient of 0.012 ; thus no relationship was verified.

Overall, the results of this study appear to demonstrate that there is little thermodynamic dependence on the incorporation of $\mathrm{Mg}^{2+}$ or $\mathrm{Sr}^{2+}$ into A. stutchburyi aragonite, as the incorporation in aragonite of both ions should be inversely dependent on temperature based on inorganic studies (Kinsman and Holland, 1969; Dietzel et al., 2004; Gaetani 
and Cohen, 2004). The only potential correlations with SST observed were positive. This may indicate that temperature has an indirect influence on the incorporation of $\mathrm{Mg}^{2+}$ or $\mathrm{Sr}^{2+}$. It is possible that an indirect temperature effect would occur via the positive influence of temperature on A. stutchburyi growth rate, which itself had a significant positive correlation with $\mathrm{Sr} / \mathrm{Ca}$ and $\mathrm{Mg} / \mathrm{Ca}$ ratios (Stecher et al., 1996; Gillikin et al., 2005). McKinnon (1996) observed a strong positive relationship between A. stutchburyi growth rate and temperature in individuals from Dunedin (Figure 4.16). The temperature-growth rate relationship could explain the corresponding decreases in SST and $\mathrm{Mg} / \mathrm{Ca}$ and $\mathrm{Sr} / \mathrm{Ca}$ ratios observed during July-August as there is a slowdown in growth rate as temperatures cool.

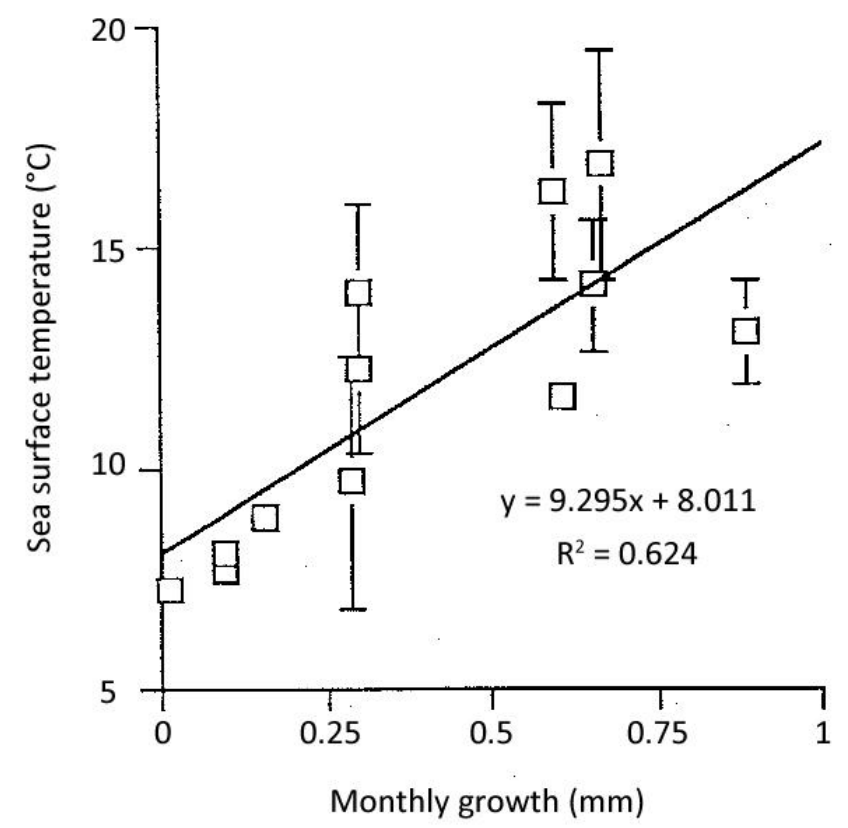

Figure 4.16 Correlation between growth rate (mm/month) and sea-surface-temperature for $A$. stutchburyi from Post Chalmers, Dunedin. Figure taken from McKinnon (1996).

Another possibility is that variations in A. stutchburyi shell architecture are responsible for some of the observed variations in $\mathrm{Mg} / \mathrm{Ca}$ and $\mathrm{Sr} / \mathrm{Ca}$ ratios in the horizontal transects. As the percentage of organic material (intra- and extra-crystalline) in the shell increases over annual growth bands, the amount of $\mathrm{Mg}^{2+}$ and $\mathrm{Sr}^{2+}$ incorporated in the shell could vary because of the different hosting properties of the organic 
component compared to the mineral $\left(\mathrm{CaCO}_{3}\right)$ component (Vander Putten et al., 2000; Schöne et al., 2011; Foster et al., 2008). A preliminary study by Foster et al. (2008) using X-ray Absorption Near Edge Spectroscopy (XANES) on Arctica islandica aragonite found that $\mathrm{Mg}^{2+}$ was not hosted by the aragonite at all, but rather was bound to organic intra- or extra-crystalline component of the shell, which caused an increase in $\mathrm{Mg} / \mathrm{Ca}$ near growth checks. Schöne et al. (2011), utilising LA-ICP-MS, observed higher $\mathrm{Mg} / \mathrm{Ca}$ ratios over organic growth checks in $A$. islandica, but also found that $\mathrm{Sr} / \mathrm{Ca}$ (which is hosted in aragonite) peaked in the aragonite component adjacent to the growth checks. Vertical variations in shell architecture in A. stutchburyi certainly affect TE/Ca ratios - as observed from LA-ICP-MS transects taken down single growth lines (Chapter 3, section 3.1). These variations occur because with distance through the $A$. stutchburyi shell, microstructure of the $\mathrm{CaCO}_{3}$ crystals changes from crossed lamellar to homogeneous. Further high-resolution analysis (microprobe or XANES) is required to investigate how, if any, horizontal variations in A. stutchburyi shell architecture affect $\mathrm{Sr} / \mathrm{Ca}$ and $\mathrm{Mg} / \mathrm{Ca}$ ratios.

Finally, Mucci and Morse (1983) proposed that $\mathrm{Mg}^{2+}$ might directly affect the substitution of $\mathrm{Sr}^{2+}$ in aragonite or calcite (Chapter 1). Across the entire dataset, $\mathrm{Mg} / \mathrm{Ca}$ and $\mathrm{Sr} / \mathrm{Ca}$ ratios were well correlated, with a sensitivity of almost 1 for many linear regressions. However, both TE/Ca ratios are also significantly correlated to growth rate, with $\mathrm{Sr} / \mathrm{Ca}$ ratios having a slightly higher correlation. On this basis, $\mathrm{Sr}^{2+}$ is probably not driven by $\mathrm{Mg}^{2+}$ incorporation, although more accurate growth rate determinations would be needed to confirm this conclusion. 


\subsection{4 $\mathrm{Ba} / \mathrm{Ca}$ ratios}

$\mathrm{Ba} / \mathrm{Ca}$ ratios ranged between $0.00-0.046 \mathrm{mmol} / \mathrm{mol}$ across the analysed $A$. stutchburyi shells. Studies on both calcitic and aragonitic bivalves have reported background $\mathrm{Ba} / \mathrm{Ca}$ ratios between $0.0005-0.0015 \mathrm{mmol} / \mathrm{mol}$, interspersed with peaks between $0.004-0.045$ mmol/mol (Elliot, 2009; Stecher et al., 1996; Gillikn et al., 2006). The overall range in A. stutchburyi $\mathrm{Ba} / \mathrm{Ca}$ ratios is comparable to these reported ranges; however, very low $(<0.0015 \mathrm{mmol} / \mathrm{mol})$ 'background' $\mathrm{Ba} / \mathrm{Ca}$ ratios were not prevalent in $A$. stutchburyi $\mathrm{Ba} / \mathrm{Ca}$ records. Rather, for each shell, the majority of $\mathrm{Ba} / \mathrm{Ca}$ ratios were $>0.002$ $\mathrm{mmol} / \mathrm{mol}$, and followed the same pattern as $\mathrm{Mg} / \mathrm{Ca}, \mathrm{Sr} / \mathrm{Ca}, \mathrm{Mn} / \mathrm{Ca}$ and $\mathrm{U} / \mathrm{Ca}$ ratios (Chapter 3). Transient peaks in $\mathrm{Ba} / \mathrm{Ca}$, which were not matched by similar peaks in the other TE/Ca records, were superimposed on these patterns. Peak amplitudes varied between individuals at different sites, and between the individuals at Ligar Bay; peaks reached $0.017,0.025$ and $0.46 \mathrm{mmol} / \mathrm{mol}$ in the Ligar Bay 1B, Kaiaua, and Ligar Bay 4B shells, respectively.

The shells with the highest $\mathrm{Ba} / \mathrm{Ca}$ peaks had the poorest $\mathrm{Ba} / \mathrm{Ca}$ correlations with other $\mathrm{TE} / \mathrm{Ca}$ ratios - $\mathrm{Mg} / \mathrm{Ca}, \mathrm{Sr} / \mathrm{Ca}, \mathrm{Mn} / \mathrm{Ca}$ and $\mathrm{U} / \mathrm{Ca}$. For example, while correlation coefficients for $\mathrm{Ba} / \mathrm{Ca}-\mathrm{Mg} / \mathrm{Ca}$ were $>0.41$ for all other shells, for Ligar Bay $3 \mathrm{~B}$ and Ligar Bay 4B, which both contained similar 3-point peaks up to 0.46 and 0.39 $\mathrm{mmol} / \mathrm{mol}$, correlation coefficients were only 0.19 and 0.05 , respectively. Excluding the large 3-point $\mathrm{Ba} / \mathrm{Ca}$ peak from the Ligar Bay 3B data yielded a correlation coefficient of 0.78 between $\mathrm{Sr} / \mathrm{Ca}$ and $\mathrm{Ba} / \mathrm{Ca}$, and from Ligar Bay $4 \mathrm{~B}$ data gave a correlation coefficient of 0.59 between $\mathrm{Sr} / \mathrm{Ca}$ and $\mathrm{Ba} / \mathrm{Ca}$. Growth rate correlations with $\mathrm{Ba} / \mathrm{Ca}$ ratios in the Ligar Bay shells were significant $\left(\mathrm{r}^{2}=0.60\right.$ for the Ligar Bay shells combined). Despite having large $\mathrm{Ba} / \mathrm{Ca}$ peaks, even the individual Ligar Bay $3 \mathrm{~B} \mathrm{Ba} / \mathrm{Ca}$ correlation with growth rate was strong $\left(r^{2}=0.89\right)$, although the increment that included 
the large $\mathrm{Ba} / \mathrm{Ca}$ peak was the most offset from the linear regression. $\mathrm{Ba} / \mathrm{Ca}$ ratios in the Ligar Bay shells were also significantly correlated with ontogenetic age (correlation coefficients between $0.61-0.96)$.

There has been speculation over the influences on 'background' $\mathrm{Ba} / \mathrm{Ca}$ ratios and what factors cause the $\mathrm{Ba} / \mathrm{Ca}$ peaks observed in mollusc shells (Lazareth, 2003; Gillikin et al., 2006; Takesue et al., 2008; Gillikin et al., 2008). It has been suggested that background $\mathrm{Ba} / \mathrm{Ca}$ ratios are controlled by dissolved $\mathrm{Ba}$, and thus are a proxy for salinity in estuaries (Gillikin et al., 2006; Gillikin et al., 2008). However, based on the significant correlation with growth rate and ontogenetic age it is argued here that 'background' $\mathrm{Ba} / \mathrm{Ca}$ ratios (i.e. all ratios excluding the peaks where $\mathrm{Ba} / \mathrm{Ca}$ record varies from other TE/Ca ratios) in A. stutchburyi are predominantly controlled by these biological effects. This is supported by the significant correlations between $\mathrm{Ba} / \mathrm{Ca}$ and $\mathrm{Sr} / \mathrm{Ca}$ ratios, which are stronger when $\mathrm{Ba} / \mathrm{Ca}$ peaks are excluded, and as discussed above, $\mathrm{Sr} / \mathrm{Ca}$ ratios are strongly growth rate dependent. Carré et al. (2006) found in $M$. donacium that $\mathrm{Ba} / \mathrm{Ca}$ ratios (including peaks) correlated with calcification rate; with a higher correlation coefficient $\left(\mathrm{r}^{2}=0.72\right)$ when $\mathrm{Ba} / \mathrm{Ca}$ ratios were on a log scale, suggesting perhaps a nonlinear relationship. Takesue et al. (2008) also noticed a relationship between growth rate and $\mathrm{Ba} / \mathrm{Ca}$ ratios by comparing the faster growing to the slower growing valve of $C$. amurensis shells. Further, Elliot et al. (2009) observed it was unlikely that background $\mathrm{Ba} / \mathrm{Ca}$ ratios in $T$. gigas were directly controlled by the amount of dissolved $\mathrm{Ba} / \mathrm{Ca}$ in seawater, because the $\mathrm{Ba} / \mathrm{Ca}$ ratios required at the particular locations in San Francisco Harbour were not realistic for the background $\mathrm{Ba} / \mathrm{Ca}$ ratios incorporated in the shells. Nevertheless, variations in dissolved seawater $\mathrm{Ba} / \mathrm{Ca}$ cannot be ruled out as an influence for the $\mathrm{Ba} / \mathrm{Ca}$ records observed in $A$. stutchburyi, at least to some extent. $\mathrm{Ba} / \mathrm{Ca}$ ratios for Ligar Bay 3B were normalised against $\mathrm{Sr} / \mathrm{Ca}$ ratios, using the method described for $\mathrm{Mg} / \mathrm{Ca}$ ratios in the previous section, with the linear regression for $\mathrm{Sr} / \mathrm{Ca}$ and $\mathrm{Ba} / \mathrm{Ca}$ 
excluding the $\mathrm{Ba} / \mathrm{Ca} 3$-point peak $\left(\mathrm{r}^{2}=0.78\right)$. The normalised $\mathrm{Ba} / \mathrm{Ca}$ ratios show variations that were not present in the $\mathrm{Ba} / \mathrm{Ca}$ record before eliminating the growth rate effect (Figure 4.17). Measurements of seawater $\mathrm{Ba} / \mathrm{Ca}$ would be required however to produce a partition coefficient and test the relationship.

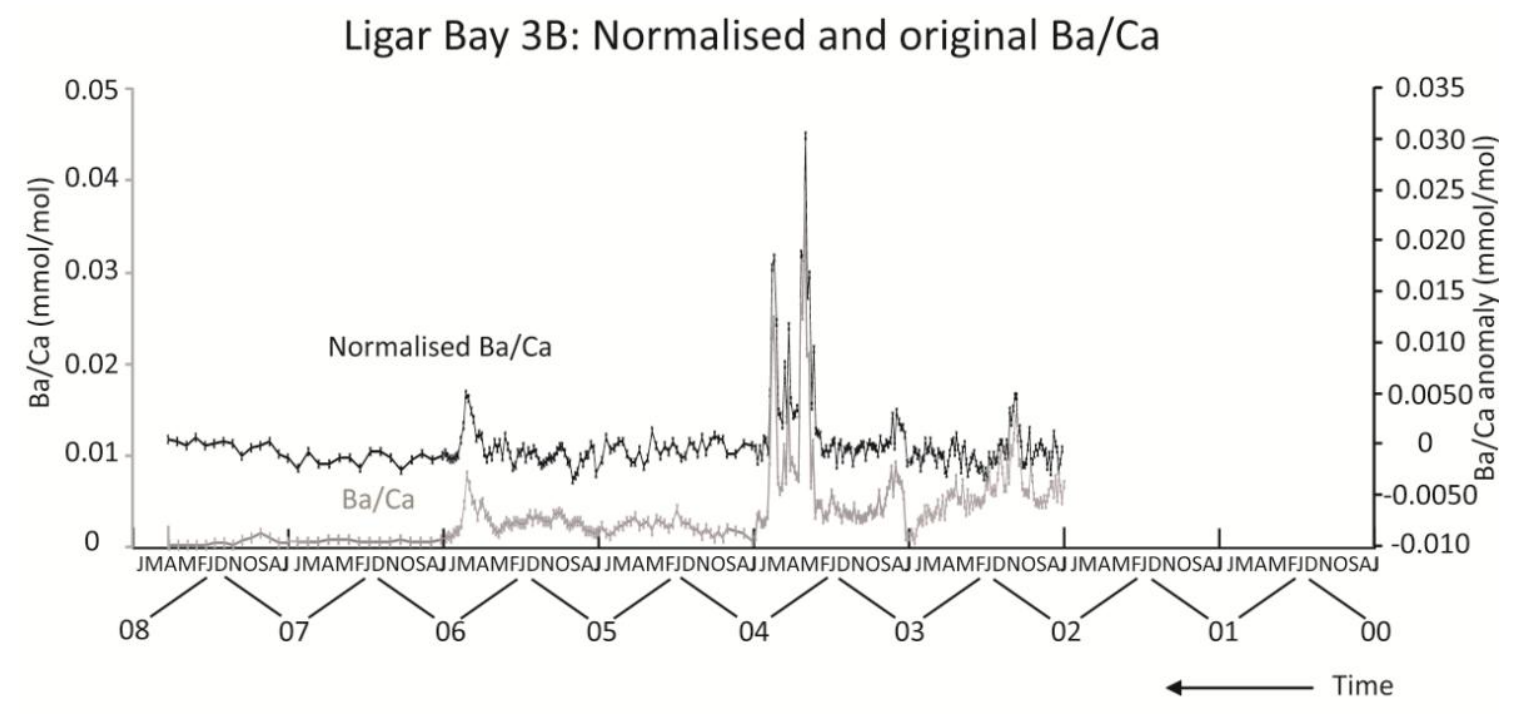

Figure 4.17 $\mathrm{Ba} / \mathrm{Ca}$ ratios from Ligar Bay 3B (grey line), compared to $\mathrm{Ba} / \mathrm{Ca}$ ratios from Ligar Bay 3B after being normalised to $\mathrm{Sr} / \mathrm{Ca}$ (black line). Constant growth rate is assumed within each annual increment (July-June)

$\mathrm{Ba} / \mathrm{Ca}$ peaks are most often associated with seasonal chlorophyll increases (Vander Putten et al., 2000; Lazareth, 2003; Gillikin et al., 2008). Elliot et al. (2009) found that peak $\mathrm{Ba} / \mathrm{Ca}$ ratios observed in the giant-bivalve Tridacna gigas from the Indo Pacific Ocean correlated strongly with local chlorophyll maxima, (background $\mathrm{Ba} / \mathrm{Ca}$ ratios and chlorophyll data plotted along a separate linear regression). The timing of $\mathrm{Ba} / \mathrm{Ca}$ peaks with chlorophyll maxima indicated that increased primary productivity was the main cause of the peaks; although the factors controlling the chlorophyll maxima at each site studied varied significantly (at Cocos Island chlorophyll maxima occurred in winter compared to Palm Island when the maxima occurred in summer in response to increased rainfall providing nutrients to phytoplankton). Chlorophyll levels vary seasonally in Golden Bay in response to seasonal stratification of the water column, which is 
primarily influenced by surface warming and nutrient input from rivers (Gall and Zeldis, 2003). At Ligar Bay in the southeastern region of Golden Bay chlorophyll peaks in springtime, according to 2001-2002 data (Figures 4.18-4.19). It is likely that these significant seasonal variations and peaks would be recorded in the Ligar Bay shells if $\mathrm{Ba} / \mathrm{Ca}$ in A. stutchburyi is sensitive to chlorophyll levels. Alternatively, $\mathrm{Ba} / \mathrm{Ca}$ peaks could be caused by an increase in dissolved $\mathrm{Ba}$ in seawater, potentially brought by river discharge in a flood (Torres et al., 2001); although Elliot et al. (2009) have pointed out that the levels of dissolved $\mathrm{Ba}$ required are unrealistically high given the range of the peak $\mathrm{Ba} / \mathrm{Ca}$ ratios in bivalves. More information on dissolved $\mathrm{Ba}$ in Golden Bay, and its sources, is necessary.
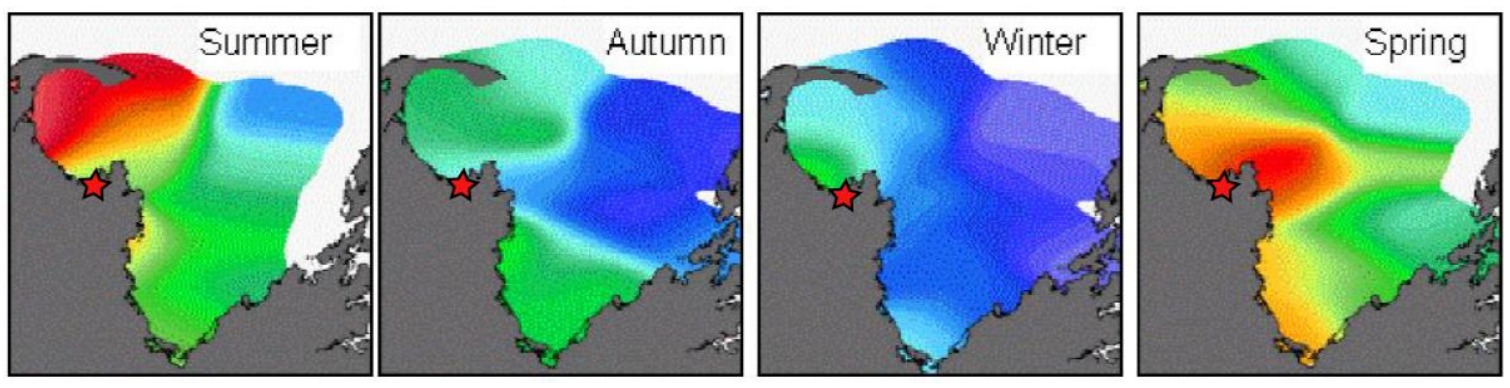

Figure 4.18 Maps of chlorophyll (phytoplankton abundance) across Golden Bay for summer, autumn, winter and spring 2001-2002. Red star shows the location of Ligar Bay. Colours represent average chlorophyll abundance from near surface to the sea bed. Low chlorophyll is shown in blue, increasing through green, to yellow, with the highest values in red. Figure taken from Gall and Zeldis (NIWA, 2003).

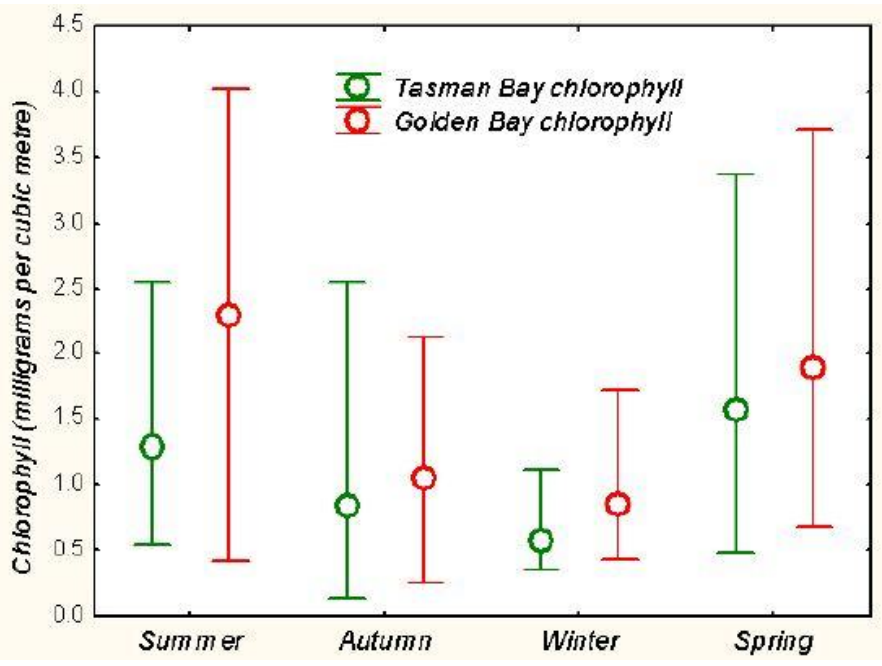

Figure 4.19 Average chlorophyll concentrations in each season of 2001-2002. Golden Bay has red circles. Bars show the maximum and minimum values. Figure taken from Gall and Zeldis (NIWA, 2003). 
No quantitative chlorophyll record was available for the life span of the A. stutchburyi in Ligar Bay, but $\mathrm{Ba} / \mathrm{Ca}$ ratios from Ligar Bay 3B and Ligar Bay $4 \mathrm{~B}$ were put on a timescale and compared to monthly total rainfall from the nearest NIWA weather station in Takaka (Figure 4.20). The figure shows the shortcomings of the chronology developed for Ligar Bay 3B and Ligar Bay 4B, and the limitation in assuming constant growth rate between annual increments. For example, the large red circle shows where smaller peaks $(0.01 \mathrm{mmol} / \mathrm{mol})$ in each record are mismatched at the end of the record. Even so, on an annual level the 3-point peaks do not appear to correlate with a major increase in rainfall in 2003-2004, although the monthly total of rainfall might have averaged out extreme, short timescale (e.g. daily) events.

\section{Ligar Bay 3B and 4B}

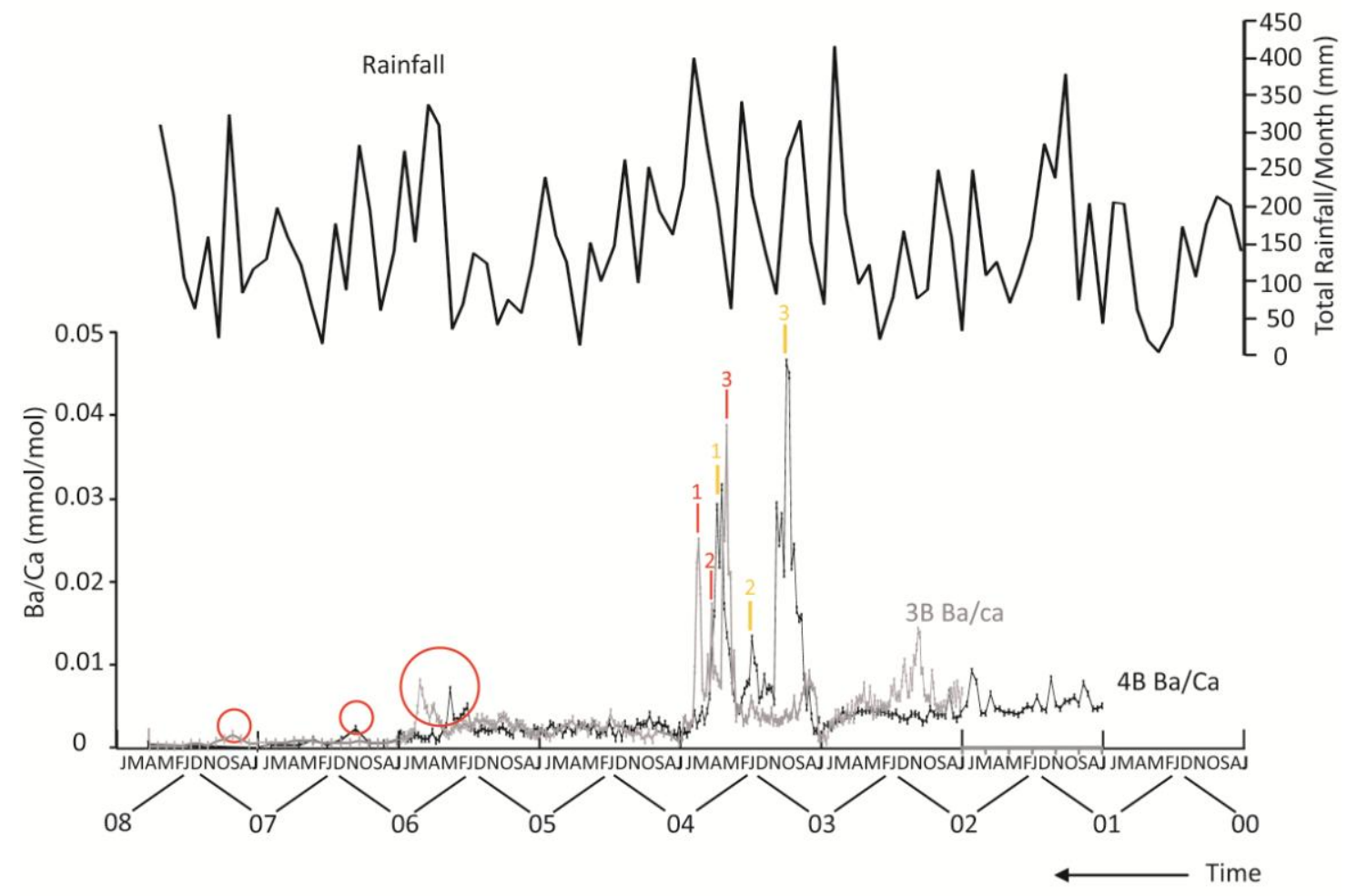

Figure 4.20 Ba/Ca ratios from Ligar Bay 3B (grey) and Ligar Bay 4B (black). Thick black line shows total monthly rainfall for July 2000-April 2008, when A. stutchburyi shells were collected. Yellow numbers denote the peak number on the 3-point peak in Ligar Bay 4B. Red numbers denote the peak number of the 3-point peak in Ligar Bay 3B. Large red circle shows the peak $(0.01$ $\mathrm{mmol} / \mathrm{mol}$, in 2006) that should correlate if the time scale was aligned correctly. Small red circles show a smaller peak in each record that is potentially the same feature, and should also be aligned. 
If the cause of the peaks was seasonal chlorophyll increases, the peaks should be periodic, as has been seen in $\mathrm{Ba} / \mathrm{Ca}$ peaks linked to phytoplankton blooms (Vander Putten et al., 2000; Gillikin et al., 2008). In Ligar Bay 3B and Ligar Bay 4B the large 3point peak is unique, and there is no periodicity of peaks. There did not appear to be periodic peaks, which could be formed annually, in the $\mathrm{Ba} / \mathrm{Ca}$ records for the other $A$. stutchburyi analysed in this study (Chapter 3). It is also unclear why only these two shells from Ligar Bay contain such large peaks; the peaks in Ligar Bay 1B and Ligar Bay $6 \mathrm{~B}$ are an order of magnitude lower. It is not possible to make comprehensive interpretations without a more highly resolved chronology and chlorophyll and rainfall data to compare the $\mathrm{Ba} / \mathrm{Ca}$ ratios directly with (e.g. Figure 4.21). However, the similarity between the Ligar Bay 3B and Ligar Bay 4B 3-point peaks do appear to demonstrate that an environmental process is responsible for $\mathrm{Ba} / \mathrm{Ca}$ peaks rather than an endogenous one in response to spawning (postulated by Gillikin et al., 2008): the synchronicity required to produce the particular 3-point shapes, spread as they were over different widths in each shell, seems very unlikely.

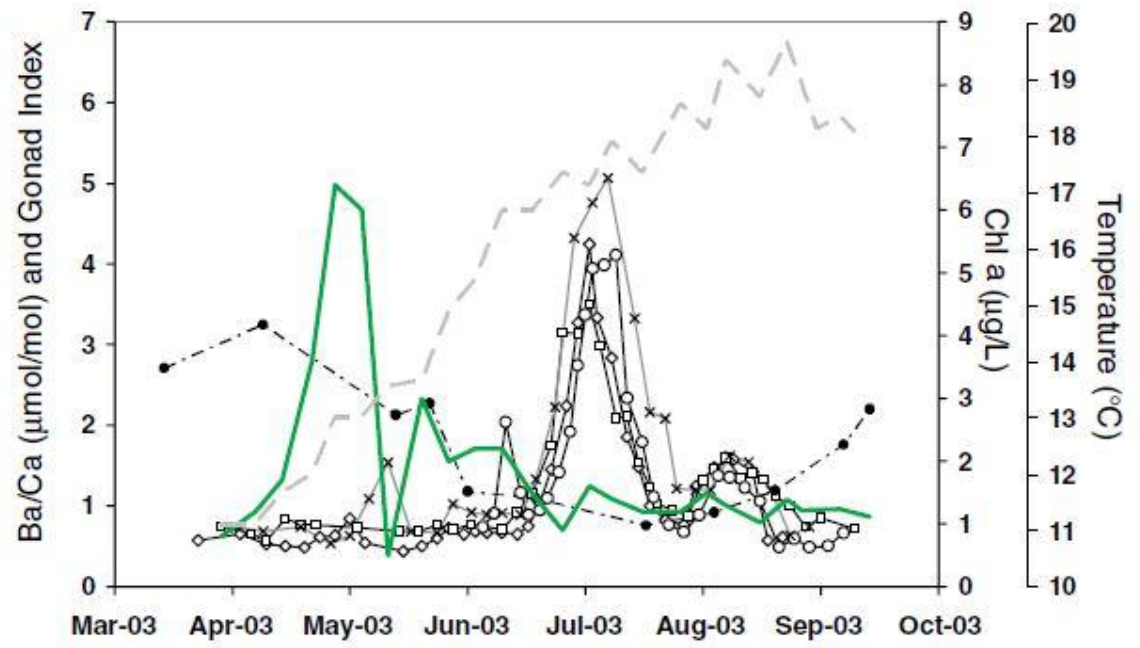

Figure 4.21 Synchronous $\mathrm{Ba} / \mathrm{Ca}$ ratio peaks in three Pecten maximus shells. The solid green line is chlorophyll a, and the dashed grey line water temperature. The dashed black line and solid black symbols are the gonad index (representative of spawning). The high-resolution timescale of the $\mathrm{Ba} / \mathrm{Ca}$ data allows from a direct comparison with chlorophyll, which reveals a delay between chlorophyll maxima and $\mathrm{Ba} / \mathrm{Ca}$ peaks. Figure taken from Gillikin et al. (2008). 


\subsection{5 $\mathrm{Mn} / \mathrm{Ca}$ and $\mathrm{U} / \mathrm{Ca}$ ratios}

The range in $\mathrm{Mn} / \mathrm{Ca}$ ratios across $A$. stutchburyi shells was $0-1.56 \mathrm{mmol} / \mathrm{mol} . \mathrm{Mn} / \mathrm{Ca}$ ratios were mostly strongly correlated to $\mathrm{Mg} / \mathrm{Ca}, \mathrm{Sr} / \mathrm{Ca}, \mathrm{Ba} / \mathrm{Ca}$ and $\mathrm{U} / \mathrm{Ca}$ with the notable exception of the Ligar Bay shells, which contained average $\mathrm{Mn} / \mathrm{Ca}$ ratios an order of magnitude lower than shells from all other sites (Chapter 3). However, even though $\mathrm{Mn} / \mathrm{Ca}$ was poorly correlated with $\mathrm{Sr} / \mathrm{Ca}$ in Ligar Bay 3B and Ligar Bay 4B, there was strong correlation between $\mathrm{Mn} / \mathrm{Ca}$ ratios and growth rate $\left(\mathrm{r}^{2}=0.72\right)$ and ontogenetic age $\left(\mathrm{r}^{2}\right.$ between $\left.0.47-0.95\right)$ in both of these shells. This suggests that growth rate and ontogenetic age are the dominant control on $\mathrm{Mn} / \mathrm{Ca}$ ratios in $A$. stutchburyi, regardless of $\mathrm{Mn}^{2+}$ source. Growth rate control is consistent with results obtained by Carré et al. (2006) on M. donacium and C. subrogosa, which had correlation coefficients between growth rate and $\mathrm{Mn} / \mathrm{Ca}$ ratios varying between 0.53 0.74 .

Fluctuations in $\mathrm{Mn}^{2+}$ may yet be responsible for the remaining variations in $\mathrm{Mn} / \mathrm{Ca}$ ratios in A. stutchburyi shell. The amount of $\mathrm{Mn}^{2+}$ in seawater is linked to oxidationreduction conditions, as well as phytoplankton blooms, as Mn is a redox sensitive element (Miao et al., 2006; Chapter 1). Variations observed in $\mathrm{Mn} / \mathrm{Ca}$ ratios in $A$. stutchburyi indicate redox conditions might influence the chemistry of its shell. Firstly, the significant variation in average $\mathrm{Mn} / \mathrm{Ca}$ ratios between the Ligar Bay shells and the remaining shells (Figure 4.22) could be explained by the redox conditions expected at the respective sites. Ligar Bay was the only site where A. stutchburyi were collected from an open beach, with medium-coarse grained sand (sourced from the Separation Point granite batholith - Muir et al., 1995). The clams were found below low tide on a sand bar; the exposure to wave action and permeable sediment would make this a relatively oxidising environment with low $\mathrm{Mn}^{2+}$ production. Conversely, the other sites 
were estuaries (Kawhia) and tidal mud-flats (Miranda, Manakau, Bay of Islands), which provide an anoxic environment because of organic material, fine-grained impermeable sediment, and less water disturbance. The shell from Miranda, where it was necessary to walk over extensive mud-flats for several hundred metres to find A. stutchburyi at low tide, had the highest average $\mathrm{Mn} / \mathrm{Ca}$ ratios. The Miranda transect also contained 3 large spikes in $\mathrm{Mn} / \mathrm{Ca}$, up to $1.55,0.86$ and $1.46 \mathrm{mmol} / \mathrm{mol}$, the magnitude of which was not seen in any of the other shell $\mathrm{Mn} / \mathrm{Ca}$ records (Figure 3.22). Secondly, there was significant variation between the $\mathrm{Mn} / \mathrm{Ca}$ ratios in the Ligar Bay shell records and the Ligar Estuary $\mathrm{Mn} / \mathrm{Ca}$ shell record (Table 4.2 shows results from a student-t test). This variation could well be caused by variation in $\mathrm{Mn}^{2+}$ production via redox, as aside from redox conditions, these sites should have similar environmental parameters (SST, source of riverine, particulate $\mathrm{Mn}$ ) because of their close proximity.

\begin{tabular}{lllll}
\hline & Ligar Estuary & & & \\
\hline & Ligar Bay 1B & Ligar Bay 3B & Ligar Bay 4B & Ligar Bay 6B \\
\hline $\mathrm{t}$ & -6.1 & -7.69 & -6.69 & -6.14 \\
$\mathrm{SD}$ & 0.00159 & 0.0305 & 0.0337 & 0.0362 \\
$\mathrm{p}$ & $<0.0001$ & $<0.0001$ & $<0.0001$ & $<0.0001$ \\
\hline
\end{tabular}

Table 4.2 Results from student-t test between Ligar Estuary and each Ligar Bay shell. P (probability) is less than 0.0001 for all tests.

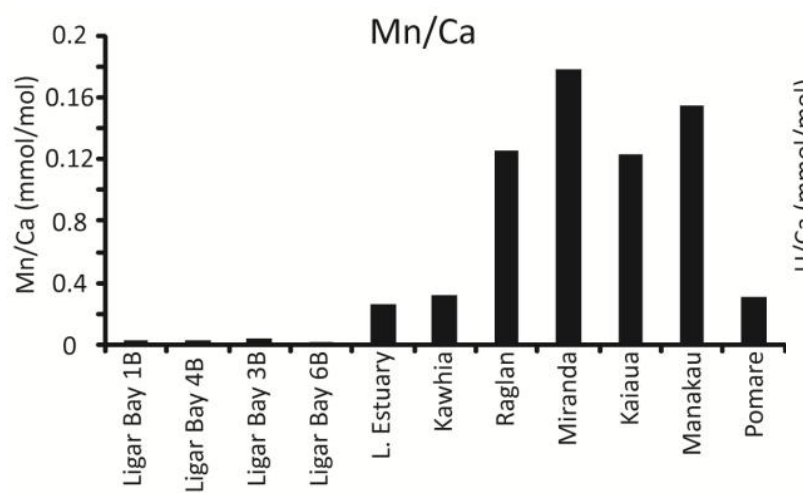

Figure 4.22 Average $\mathrm{Mn} / \mathrm{Ca}$ ratios in each $A$. stutchburyi shell

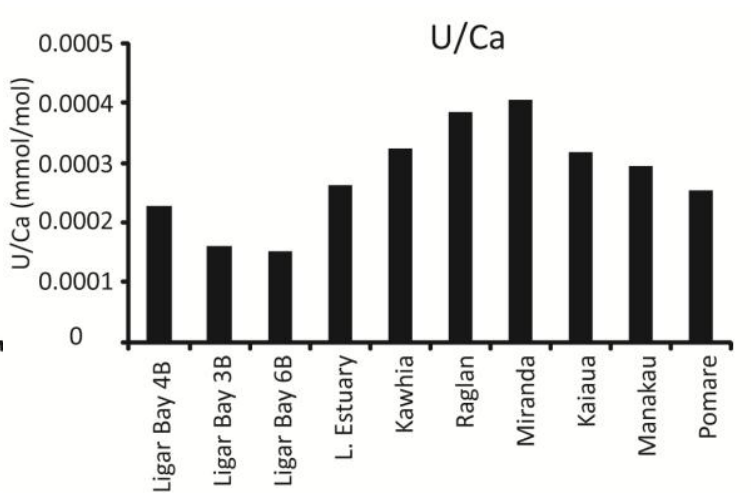

Figure 4.23 Average U/Ca ratios in each A. stutchburyi shell 
It is difficult to eliminate the effect of growth rate from $\mathrm{Mn} / \mathrm{Ca}$ ratios in the Ligar Bay 3B and Ligar Bay 4B shells so that the remaining variations can be plotted on a time series, because $\mathrm{Sr} / \mathrm{Ca}$ does not correlate with $\mathrm{Mn} / \mathrm{Ca}$ in these shells. If an improved chronology was constructed for the A. stutchburyi shells, it would enable highresolution growth rate calculation, which could then be used to eliminate the physiological effects from the $\mathrm{Mn} / \mathrm{Ca}$ data and further assess the $\mathrm{Mn}$ redox proxy potential.

Another possible influence on $\mathrm{Mn} / \mathrm{Ca}$ ratios in A. stutchburyi are phytoplankton levels, which have been linked to peaks in $\mathrm{Mn} / \mathrm{Ca}$ in other bivalve species (Vander Putten et al., 2000; Lazareth, 2003). As discussed above for $\mathrm{Ba} / \mathrm{Ca}$, chlorophyll variations are expected in the Ligar Bay region, and thus may transmit to $\mathrm{Mn} / \mathrm{Ca}$ variations in $A$. stutchburyi shells. Where $\mathrm{Mn} / \mathrm{Ca}$ ratios have been linked to chlorophyll maxima (caused by phytoplankton blooms) the $\mathrm{Mn} / \mathrm{Ca}$ records have shown similar periodic peaks to $\mathrm{Ba} / \mathrm{Ca}$ peaks described above (e.g. Figure 4.25). There were only several $A$. stutchburyi shells that showed peaks comparable to these on top of the pattern followed by $\mathrm{Mg} / \mathrm{Ca}$ and $\mathrm{Sr} / \mathrm{Ca}$ - Ligar Bay 1B, Ligar Bay 3B, Pomare and Miranda, although peaks were an order of magnitude higher at Miranda (Chapter 3). The periodicity of the peaks in Ligar Bay 1B, Ligar Bay 3B and Pomare shells could potentially be seasonal (Figure 4.24). However, a high resolution chronology, and real-time chlorophyll measurements would be required to discover whether the peaks are synchronous with chlorophyll maxima, to assess whether $\mathrm{Mn} / \mathrm{Ca}$ in $A$. stutchburyi is related to phytoplankton availability.

A further factor to consider is the relative amounts of organic material and mineral component in the shell. Takesue et al. (2008) found in aragonitic C. amurensis bivalves that the component of $\mathrm{Mn}$ that was non-lattice-bound (i.e. bound to organic 
material) equated to $78 \%$. Therefore variations in $\mathrm{Mn} / \mathrm{Ca}$ observed in aragonitic $A$. stutchburyi might not reflect $\mathrm{Mn}$ substitution into $\mathrm{CaCO}_{3}$, and this could have implications for the use of $\mathrm{Mn} / \mathrm{Ca}$ as an environmental proxy.

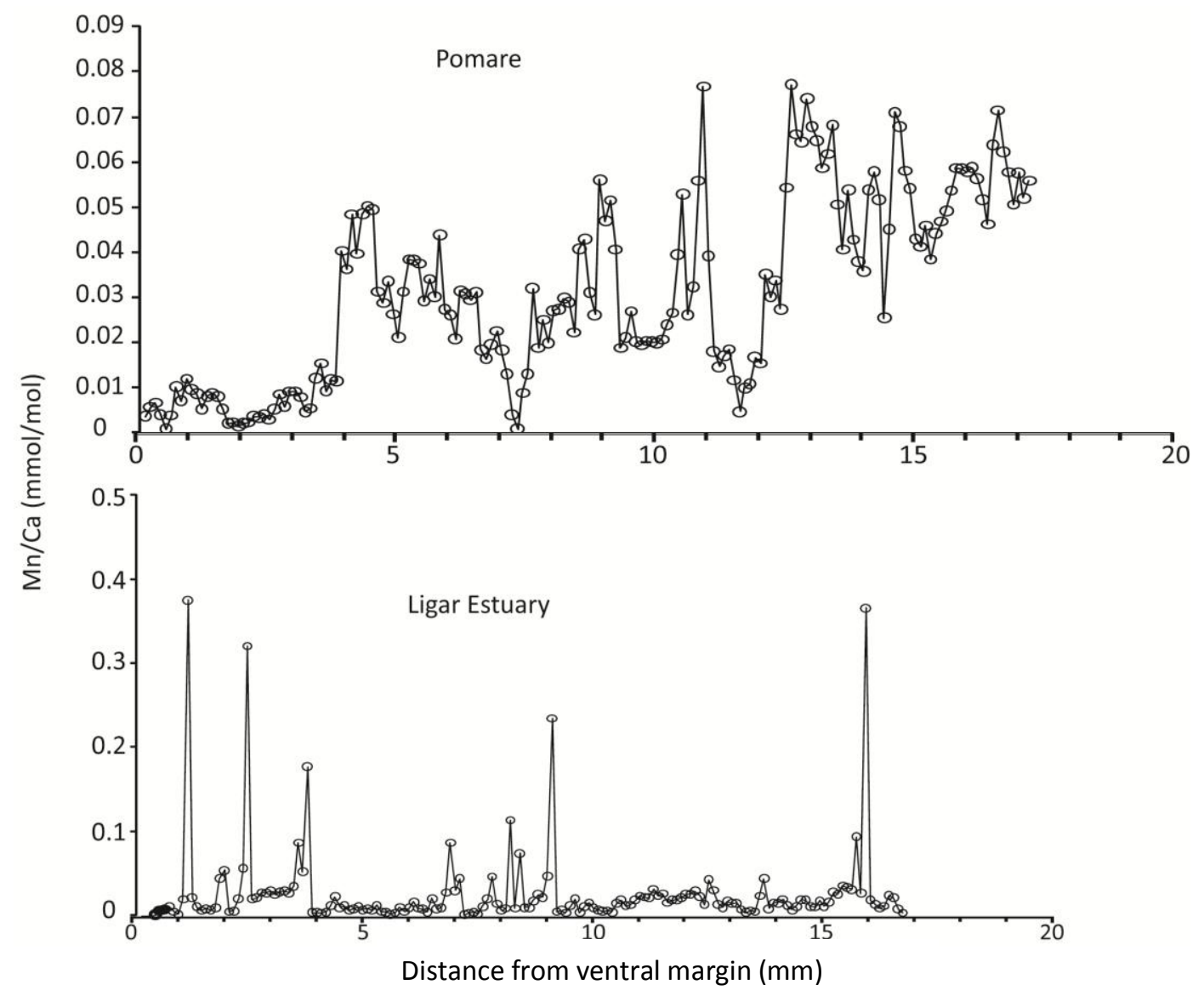

Figure 4.24 Mn/Ca records from Pomare and Ligar estuary, showing spikes in $\mathrm{Mn} / \mathrm{Ca}$.

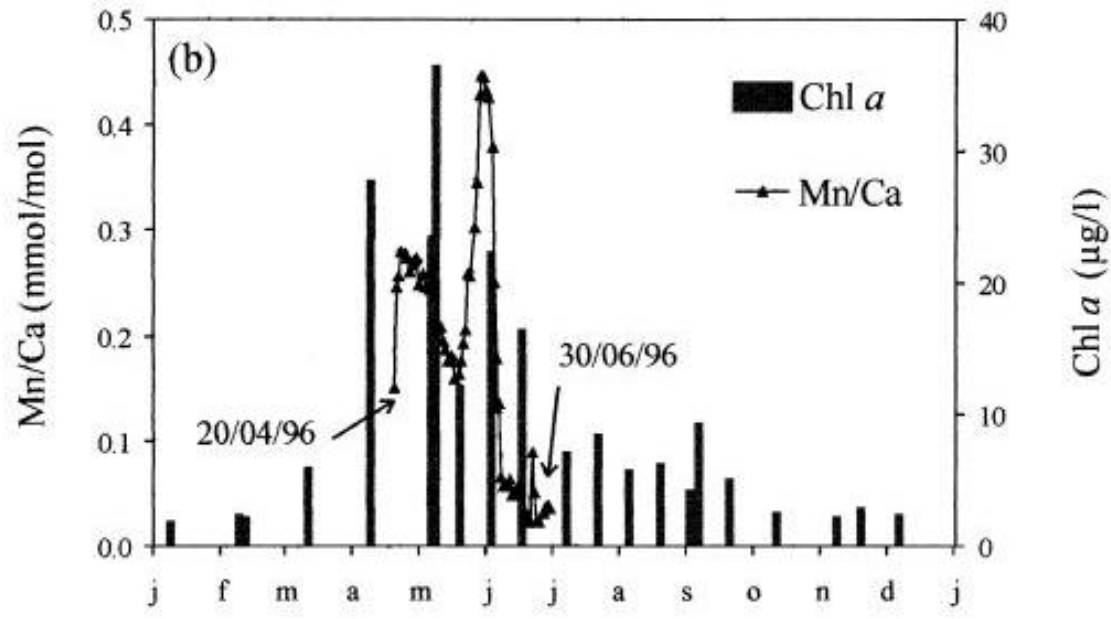

Month

Figure 4.25 $\mathrm{Mn} / \mathrm{Ca}$ profiles in the calcite shell layer of a M. edulis compared to measured chlorophyll $a$ concentrations. The shell grew from the $20^{\text {th }}$ April 1996 until the 30th June 1996; the data points correspond to shell formed during this period. Arrows indicate the moment of transplantation and the moment when the mussel was removed from the transplantation site. Figure taken from Vander Putten et al. (2000). 
$\mathrm{U} / \mathrm{Ca}$ ratios ranged between $0-0.0013 \mathrm{mmol} / \mathrm{mol}$ in A. stutchburyi. As with $\mathrm{Mn} / \mathrm{Ca}$, $\mathrm{U} / \mathrm{Ca}$ was generally strongly correlated with the other $\mathrm{TE} / \mathrm{Ca}$ ratios $(\mathrm{Mn} / \mathrm{Ca}, \mathrm{Mg} / \mathrm{Ca}$, $\mathrm{Ba} / \mathrm{Ca}$ and $\mathrm{Sr} / \mathrm{Ca}$ ); with some exceptions for the Ligar Bay shells and Ligar Estuary shell (Chapter 3). Both growth rate and ontogenetic age were significantly correlated with U/Ca ratios in the Ligar Bay shells $\left(\mathrm{r}^{2}=0.63\right.$ and between 0.61-0.92, respectively). Therefore, it is thought these two effects are also the dominant control on $\mathrm{U}$ incorporation in A. stutchburyi.

As $U$ is also a redox-sensitive element, and accumulates in anoxic, organic-rich marine sediments (Barnes and Cochran, 1991; Morford et al., 1999; Bots and Behrends, 2008) it is possible that remaining $\mathrm{U} / \mathrm{Ca}$ variations could be influenced by redox conditions. Two of the same observations seen in the average $\mathrm{Mn} / \mathrm{Ca}$ ratios applied to the average U/Ca ratios - the Ligar Bay shells contained the lowest U/Ca ratios, and Miranda the highest. However, the Ligar Bay U/Ca ratios are broadly the same as shells from the other sites, and intermediate to the Miranda and Ligar Bay shells, the average U/Ca ratios of the other sites do not follow the same order as for $\mathrm{Mn} / \mathrm{Ca}$ (Figure 4.23 average $\mathrm{U} / \mathrm{Ca}$ ratios, above). Nevertheless, the similarities between $\mathrm{U} / \mathrm{Ca}$ and $\mathrm{Mn} / \mathrm{Ca}$ ratios; with Ligar Bay and Miranda; and the lower correlations with other TE/Ca ratios at the oxic Ligar Bay site, potentially suggest a redox link to the variations in these $\mathrm{TE} / \mathrm{Ca}$ ratios and the possibility that their record could be a proxy for redox conditions. Further investigation is needed including constructing high-resolution chronologies for A. stutchburyi and measurements of redox conditions from the clams' environment, so that $\mathrm{U} / \mathrm{Ca}$ records can be directly compared to them. 


\subsubsection{As/Ca, $\mathrm{Zn} / \mathrm{Ca}$ and $\mathrm{Cu} / \mathrm{Ca}$ ratios}

These metals were noticeably elevated in the Ligar Bay shells and Ligar Estuary shell compared to the other shells, which may indicate more pollution at this site - potentially from a cement works in the neighbouring bay. It should be noted, however, that throughout the transects, $\mathrm{As} / \mathrm{Ca}, \mathrm{Zn} / \mathrm{Ca}$ and $\mathrm{Cu} / \mathrm{Ca}$ ratios were often 0.00 , because the sample signal was relatively low for these low concentration metals (Chapter 3). It was important to assess the control growth rate and ontogenetic age had on the incorporation of these metals - as it significantly affects the potential to use these TE/Ca ratios as tracers of pollution. Growth rate appeared to have an insignificant influence on As/Ca and $\mathrm{Cu} / \mathrm{Ca}$ ratios, with correlation coefficients of 0.29 and 0.20 respectively. Growth rate had a larger influence on $\mathrm{Zn} / \mathrm{Ca}$ ratios, with a correlation coefficient of 0.49 . Ontogenetic age differed from growth rate - with As/Ca ratios appearing to be most strongly influenced by age $\left(\mathrm{r}^{2}=0.51\right)$, and $\mathrm{Zn} / \mathrm{Ca}$ and $\mathrm{Cu} / \mathrm{Ca}$ not showing any correlation (correlation coefficients of 0.052 and 0.0024 respectively). Although the effect of ontogenetic age was not quantified for A. stutchburyi outside of Ligar Bay, the decreasing trend was noticeable in the Pomare and Kawhia As/Ca records (Figure 4.26). Figure 4.26 illustrates how the decrease in As/Ca of all Ligar Bay shells could be interpreted as an environmental change, but given the similar ontogenetic trend of some of the other shells from different sites (Pomare, Kaiaua), it is more likely a biological change in As/Ca incorporation. 


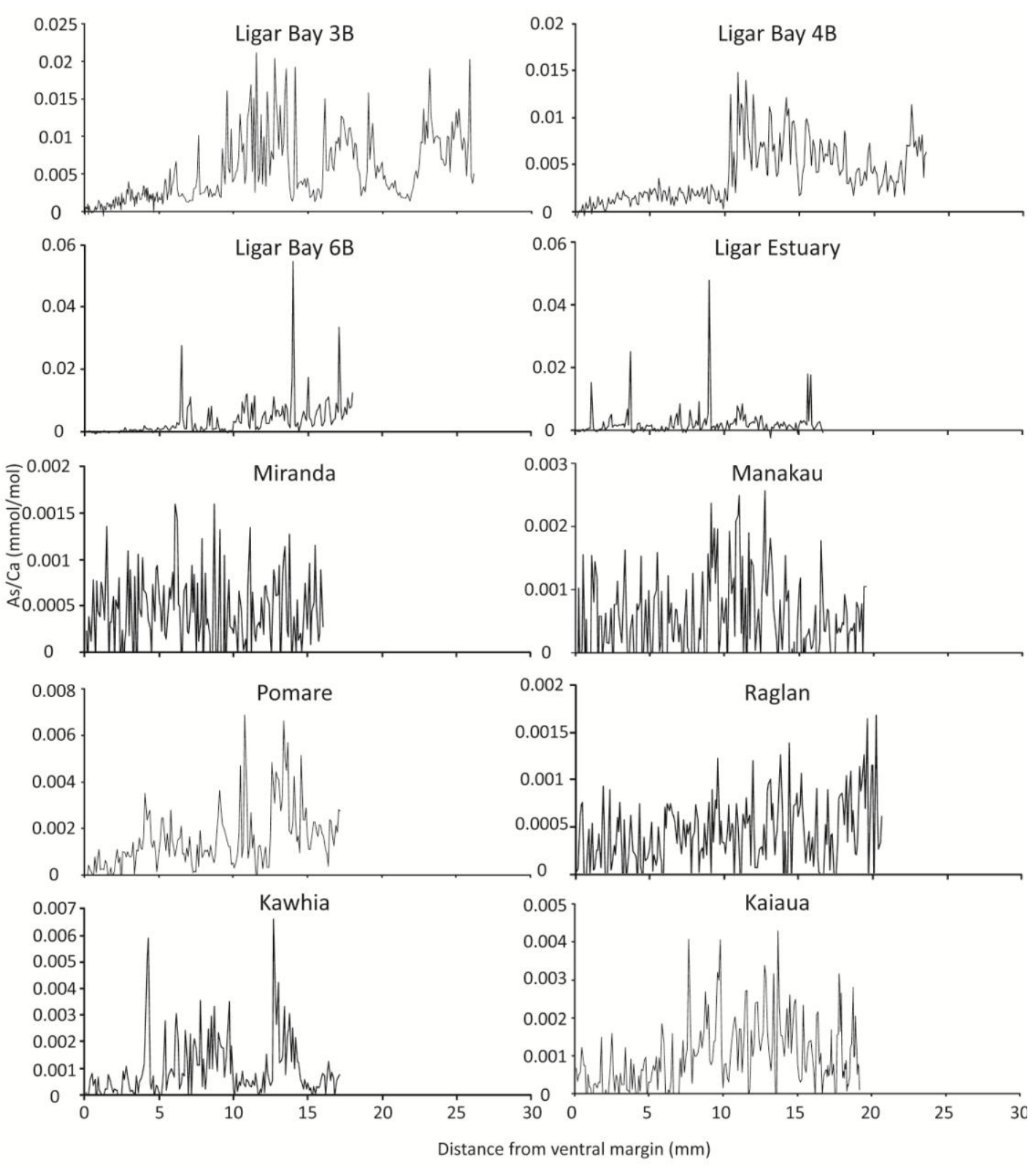

Figure 4.26 As/Ca records from all shells (except Ligar 1B where As was not measured), plotted against distance from the ventral margin. 


\subsection{Summary and comparison to other molluscan studies}

The $\mathrm{Mg} / \mathrm{Ca}$ and $\mathrm{Sr} / \mathrm{Ca}$ results obtained for A. stutchburyi appear to be consistent with other trace element studies of molluscs produced so far that have found the incorporation of those trace elements into aragonite and calcite is not governed by thermodynamics (Table 4.3-4.4). In a few instances where $\mathrm{Mg} / \mathrm{Ca}$ and $\mathrm{Sr} / \mathrm{Ca}$ did appear to follow SST (e.g. coincidence of minima) this is possibly due to an indirect temperature influence through positive correlation of SST and A. stutchburyi growth rate. This relationship has also been postulated for M. edulis (Dodd, 1965) and $P$. maximus (Freitas et al., 2006). Growth rate and ontogenetic age appear to be the dominating control on $\mathrm{Mg} / \mathrm{Ca}$ and $\mathrm{Sr} / \mathrm{Ca}$ ratios in A. stutchburyi.

These biological effects also appear to be the primary control on $\mathrm{Ba} / \mathrm{Ca}, \mathrm{Mn} / \mathrm{Ca}$ and $\mathrm{U} / \mathrm{Ca}$ ratios in A. stutchburyi. The range in $\mathrm{Ba} / \mathrm{Ca}$ ratios found in A. stutchburyi, fit within the range observed in other bivalves (argonitic and calcitic), which was suggested by Gillikin et al. (2008) to indicate a strong biological control on $\mathrm{Ba}^{2+}$ incorporation (as differences would otherwise be expected between the species and the two polymorphs of $\left.\mathrm{CaCO}_{3}\right)$. Very low background $\mathrm{Ba} / \mathrm{Ca}$ ratios $(<0.0015 \mathrm{mmol} / \mathrm{mol})$ were not typical in A. stutchburyi and the "background" variation in the clam, as stated, was correlated with growth rate and ontogeny. However, the characteristic peaks seen in $\mathrm{Ba} / \mathrm{Ca}$ shell records were superimposed on effects driven by growth rate variation. The identical 3-point $\mathrm{Ba} / \mathrm{Ca}$ peaks in the Ligar Bay 3B and Ligar Bay 4B shells are the best example of these features; and are most likely caused by an environmental process (phytoplankton blooms or elevation of dissolved $\mathrm{Ba}^{2+}$ from flooding) rather than being related to Ba availability during the clam's reproductive cycle (Gillikin et al., 2008). Large scale variations in $\mathrm{Mn} / \mathrm{Ca}$ and $\mathrm{U} / \mathrm{Ca}$ ratios seem to be associated with the redox conditions in the clams' habitat - Miranda (anoxic) and Ligar Bay (oxic). This has been 
found for Mn/Ca ratios in P. maximus by Freitas et al. (2006), although U/Ca does not appear to have been considered in previous studies. Nonetheless, primary productivity cannot be ruled out as an influence for $\mathrm{Mn} / \mathrm{Ca}$ ratios; as it has also been linked to sudden $\mathrm{Mn} / \mathrm{Ca}$ peaks (Vander Putten et al., 2000), which were present in some $A$. stutchburyi.

\subsubsection{Growth rate and ontogenetic trends}

The strong correlations between growth rate and ontogenetic age with $\mathrm{Mg} / \mathrm{Ca}, \mathrm{Sr} / \mathrm{Ca}$, $\mathrm{Mn} / \mathrm{Ca}, \mathrm{Ba} / \mathrm{Ca}$ and $\mathrm{U} / \mathrm{Ca}$ ratios in $A$. stutchburyi are consistent with the increasing number of molluscan studies that have found physiological (ontogenetic age) and kinetic (growth rate) processes have a major control on trace element incorporation. However, there is no common trend between species studied as to whether growth rate and ontogeny increases or decreases trace element incorporation; nor is there a trend between aragonite and calcite mollusc shells. For example, in aragonitic Tridacna gigas (Elliot et al., 2009) and Arctica islandica (Schöne et al., 2011) and calcitic Pinna nobilis (Freitas et al., 2005), Mg/Ca ratios correlate negatively with growth rate and correlate positively with ontogenetic age; while in aragonitic Protothaca staminea (Takesue and van Geen, 2004), Mesodesma donacium, Chione subrogosa (Carré et al., 2006), Saxidomus giganteus (Gillikin et al., 2005), and calcitic Mytilus edulis (Vander Putten et al., 2000) and Pecten maximus (Lorrain et al., 2005) Sr/Ca ratios (and Mg/Ca, $\mathrm{Mn} / \mathrm{Ca}$ and $\mathrm{Ba} / \mathrm{Ca}$ ratios for Mesodesma donacium, Chione subrogosa) correlate positively with growth rate and negatively with ontogenetic age. Trace element incorporation in A. stutchburyi behaves similarly to the latter group of molluscs.

Heterogeneity between individuals from the same species, and within individual shells has also been reported for growth rate and ontogenetic age-TE/Ca trends (Schöne et al., 2011; Carré, 2006). For example, Carré et al. (2006) observed that the influence of 
growth rate was stronger, and $\mathrm{Sr} / \mathrm{Ca}$ ratios were higher in curved shell sections of Mesodesma donacium, Chione subrogosa than in flat, long sections. This formed part of Carré's (2006) reasoning for a third mechanism, driven by calcification rate, for $\mathrm{Ca}^{2+}$ (and $\mathrm{Sr}^{2+}$ and $\mathrm{Ba}^{2+}$ ) ion transport through calcium channels, which allows different amounts of $\mathrm{Sr}^{2+}$ and $\mathrm{Ba}^{2+}$ to enter the EPF at specific locations depending on the channel density on cell membranes. Resolution of growth rate determination was not as high in the current study to observe this heterogeneity within A. stutchburyi and validate or negate this third mechanism of $\mathrm{Ca}^{2+}$ transport. However, as discussed above, the growth rate-TE/Ca ratio relationships found for Ligar Bay shells did vary between individuals, and the slow-growing Ligar Bay 6B shell having the weakest correlation with growth rate and ontogenetic age supports the suggestion by Carré et al. (2006), that slow growing individuals are not strongly affected by the calcium channel model.

Finally, Schöne et al. (2011) argued that further analyses of short-lived bivalves, including individuals from different habitats, was required to prove that environmental fluxes with a greater period than the bivalve's life (e.g. decadal) were not the cause of reported ontogenetic trends. Although ontogenetic trends were quantified only for the Ligar Bay A. stutchburyi in this study, these trends were also noticeable in the TE/Ca records for all other shells analysed (Chapter 3). The other sites where A. stutchburyi were collected from had different environmental parameters to Ligar Bay - up to $3^{\circ} \mathrm{C}$ higher average SST, and sheltered mud flats or estuaries rather than an open beach. This therefore indicates that the ontogenetic trends in A. stutchburyi are a biological effect, rather than an environmental one as Schöne et al. (2011) question. 


\begin{tabular}{|c|c|c|c|c|c|c|c|}
\hline & 흘 & & & 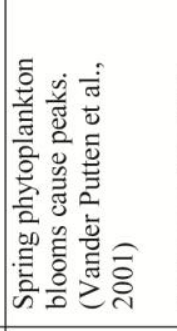 & 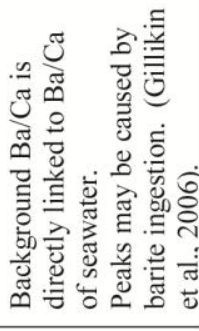 & 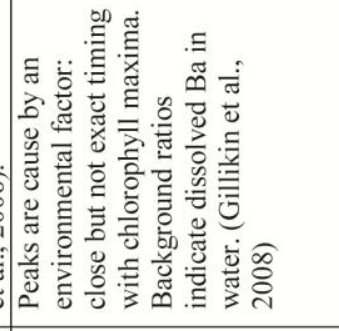 & 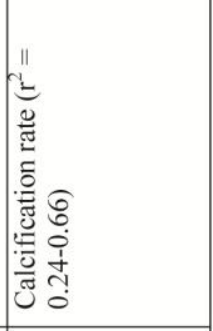 \\
\hline \multirow[t]{2}{*}{ 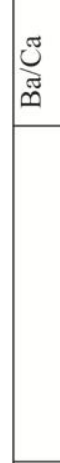 } & \begin{tabular}{|l}
$\mathscr{\Xi}$ \\
品 \\
$\approx$ \\
$\simeq$
\end{tabular} & & & 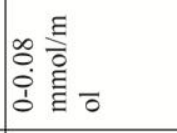 & & 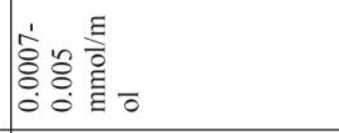 & 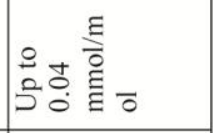 \\
\hline & 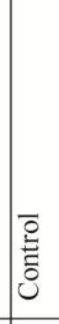 & & & 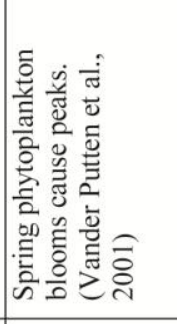 & & 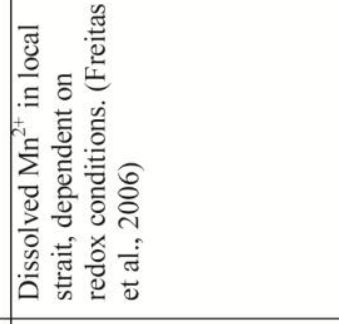 & 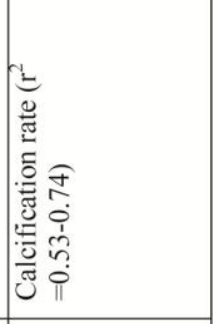 \\
\hline \multirow[t]{2}{*}{$\bigcup^{\tilde{J}}$} & 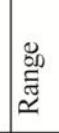 & & & $\begin{array}{l}\text { in } \\
\vdots \\
0 \\
0\end{array}$ & & 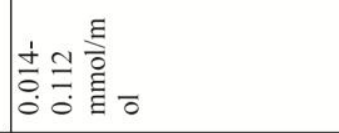 & 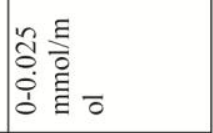 \\
\hline & రृ & 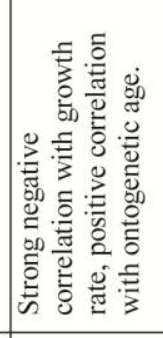 & 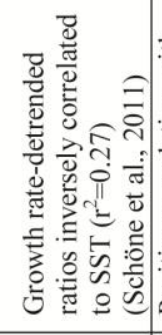 & 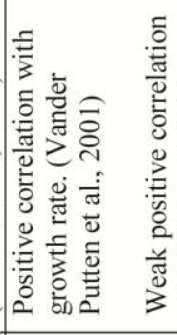 & 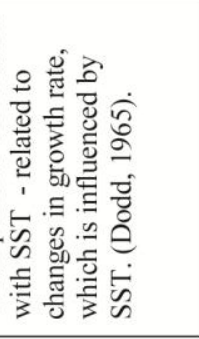 & 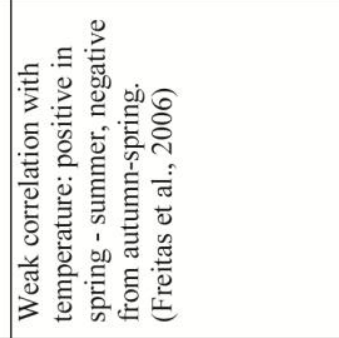 & 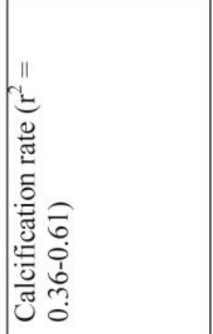 \\
\hline ש̃ & 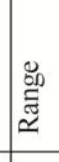 & 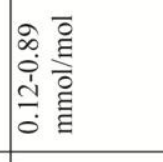 & & & & 证 & 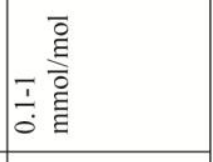 \\
\hline & סृ & 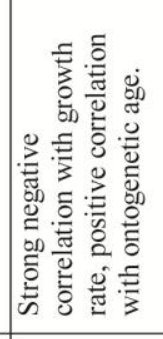 & 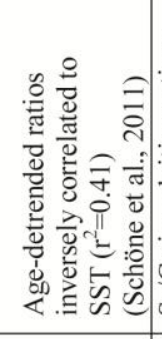 & 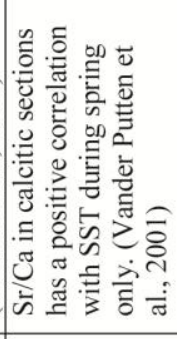 & 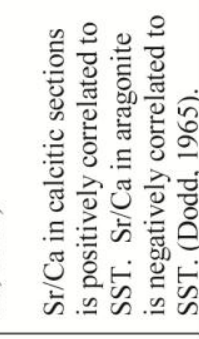 & 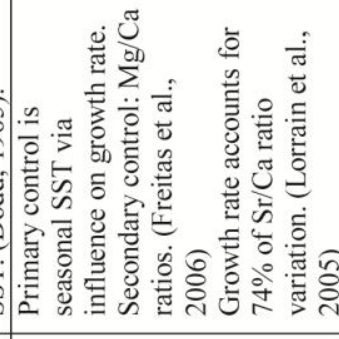 & 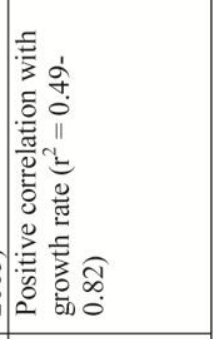 \\
\hline లో & $\begin{array}{l}\mathscr{8} \\
\text { 券 } \\
\simeq \\
\simeq\end{array}$ & 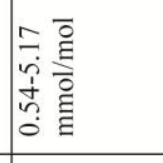 & & 竞 & & 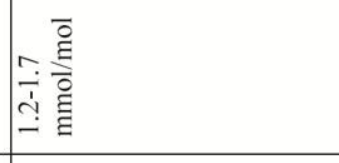 & 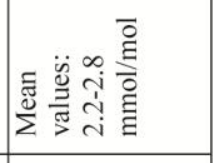 \\
\hline 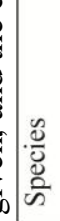 & & 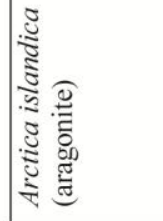 & & 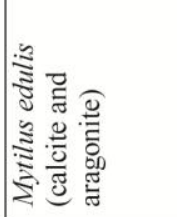 & & 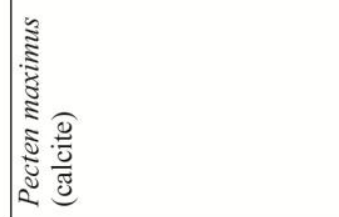 & 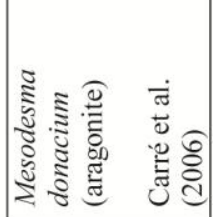 \\
\hline
\end{tabular}




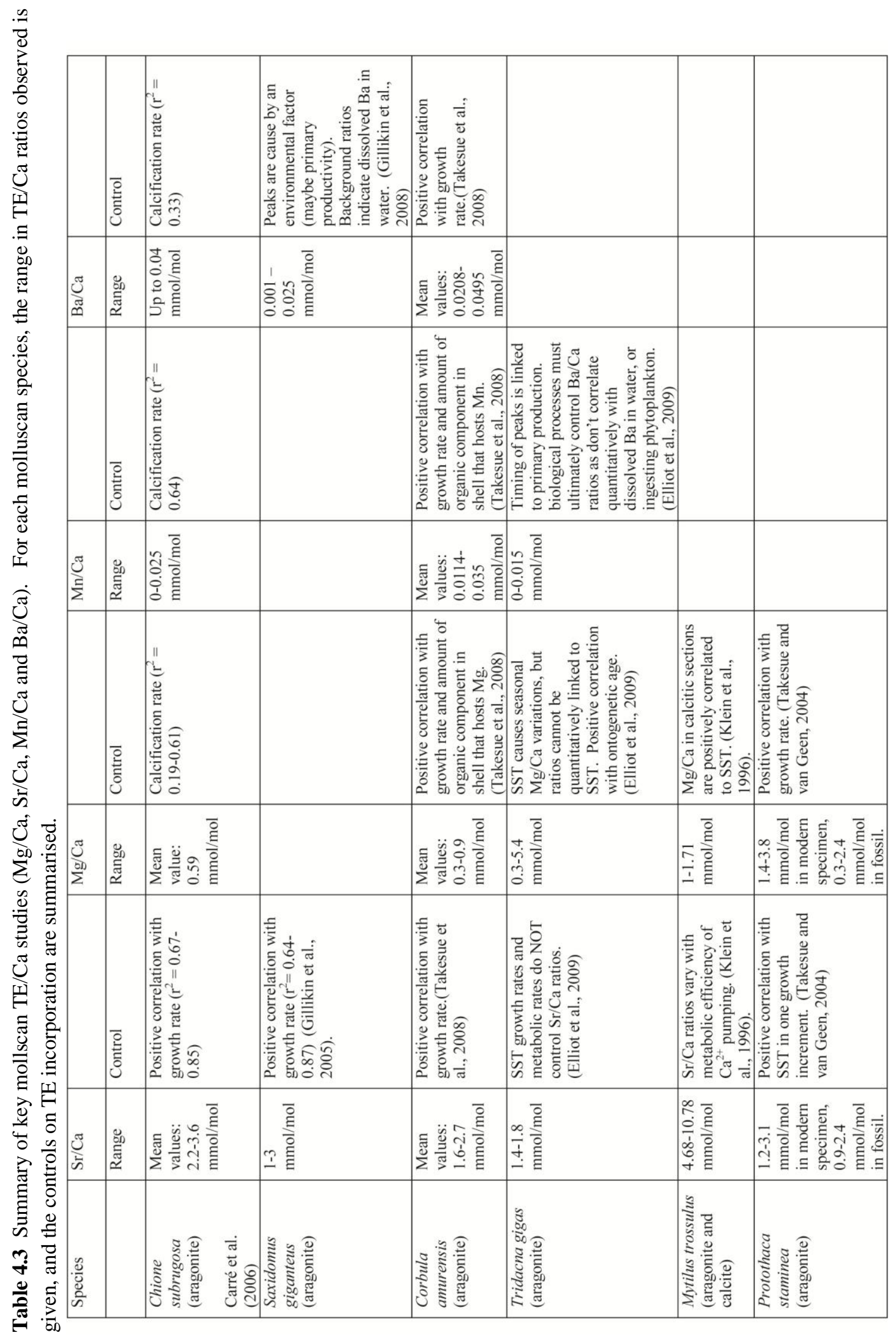




\subsection{Evaluation of $A$. stutchburyi as an archive for past environmental change}

The resolution of geochemical data obtained from A. stutchburyi in this study was annual at best due to difficulties identifying daily growth increments/bands with the time and technology available. However, the potential resolution of the clam is not necessarily limited to annual timescale - the highest resolution that could be achieved is tidal, as tidal increments were visible in some sections of the shells. There is a chance these micro-increments would be identifiable so they could be counted with more etching, and acetate peels or scanning electron microscope imaging. Alternatively, by studying the clams in culture or in situ, growth measurements could be made periodically while the individuals are still growing (McKinnon, 1996). $\delta^{18} \mathrm{O}$ analyses from the same location as LA-ICP-MS points could also possibly refine the current chronology, and possibly improve it to a seasonal resolution.

The more problematic aspect of A. stutchburyi scelerochronology as far as paleoclimatic applications are considered is the continuity of the records derived. Complete growth cessation has been found to occur in A. stutchburyi in Dunedin - a cool environment, between 3-4 months over winter (McKinnon, 1996). These periods where microincrements are not deposited may be shorter in warmer environments, however, further works is required to assess this possibility. Furthermore, the number of microincrements in A. stutchburyi only correlates exactly to the number of low-tides for two months over summer (McKinnon, 1996; Coutts, 1974). This problem might be overcome to some extent by counting the number of fortnightly bands of microincrements, caused by differences in spring and neap tides - if they could be identified (Carré et al., 2005; Carré et al., 2006). It should also be noted that molluscan records can never provide a truly continuous record of environmental conditions, as shell is only precipitated when the individuals are submerged (Schöne, 2008). Therefore, as the tidal 
cycle progresses, the shell records information from different hours in the day. This does not preclude the usefulness of molluscan proxies, but is a limitation to be considered when interpreting climatic information derived from them. On the whole, it appears that an A. stutchburyi proxy (at least from a cool climate) would under represent the winter months, and would record daily environmental change for only some periods in the year. A. stutchburyi from warmer climates may be of more use for recording seasonal change, as winter data might not be underestimated or left out.

The results from this study suggest $A$. stutchburyi is unlikely to be a useful paleo-SST proxy using $\mathrm{Mg} / \mathrm{Ca}$ or $\mathrm{Sr} / \mathrm{Ca}$ ratios. However, there is promising potential for proxies for primary production $(\mathrm{Ba} / \mathrm{Ca}$ and maybe $\mathrm{Mn} / \mathrm{Ca})$, or flood events/Ba influx $(\mathrm{Ba} / \mathrm{Ca})$, and redox conditions $(\mathrm{Mn} / \mathrm{Ca}, \mathrm{U} / \mathrm{Ca})$. The $\mathrm{Ba} / \mathrm{Ca}$ proxy could potentially be very useful - as limited paleo-data is available to constrain the Ba budget in the oceans (Freitas et al., 2006).

Finally, this study did not analyse any A. stutchburyi fossils. This would be of prime importance if the proxies described above were subsequently found to be viable in modern specimens. The chemical composition of the shell may alter with time due to diagenesis and under or over represent certain TE/Ca ratios - as has been observed in Protothaca staminea fossils (Takesue and van Geen, 2004). 


\section{CHAPTER 5.0 CONCLUSIONS}

The approach of this thesis was to analyse TE/Ca ratios in multiple A. stutchburyi individuals, including a comparison of several clams from the same site (Ligar Bay), as well as clams from a range of sites throughout NZ. The purpose of this was to assess the variation, or similarities in shell $\mathrm{TE} / \mathrm{Ca}$ ratios between the individuals, which could provide information on TE incorporation and the usefulness of A. stutchburyi shell chemistry as a recorder of past environmental change. A secondary focus of the study was to attempt scelerochronological analysis of A. stutchburyi growth patterns, so $\mathrm{TE} / \mathrm{Ca}$ ratios could be temporally assessed and compared to environmental parameters (such as SST); and so that the potential temporal resolution of A. stutchburyi geochemical records could be evaluated.

The major findings and implications of this study are:

1. Significant variability was observed in TE/Ca ratio transects measured parallel to maximum growth direction between individuals from the Ligar Bay site. There were no specific variations/patterns in the $\mathrm{Sr} / \mathrm{Ca}, \mathrm{Mg} / \mathrm{Ca}$ or $\mathrm{U} / \mathrm{Ca}$ records that could be correlated between the Ligar Bay shells. This implies that environmental factors are not primarily in control of TE/Ca ratios in A. stutchburyi shells. In particular, for $\mathrm{Mg} / \mathrm{Ca}$ and $\mathrm{Sr} / \mathrm{Ca}$ it appears thermodynamic-controlled substitution for $\mathrm{Ca}+$ in the crystal lattice does not occur, because similar seasonal, sinusoidal trends were not observed amongst the Ligar Bay records.

2. Although a high-resolution chronology could not be constructed for A. stutchburyi in this study, the identification of annual bands allowed growth rate to be calculated for annual increments. Subsequent comparison with average increment TE/Ca ratios revealed growth rate is strongly positively correlated with $\mathrm{Mg} / \mathrm{Ca}, \mathrm{Sr} / \mathrm{Ca}, \mathrm{Mn} / \mathrm{Ca}, \mathrm{U} / \mathrm{Ca}$, $\mathrm{Ba} / \mathrm{Ca}$, and ontogenetic age is strongly negatively correlated with the same TE/Ca ratios. 
Therefore, it has been suggested that these biological effects are primarily in control of trace element incorporation in A. stutchburyi.

3. There was a marked similarity between the $\mathrm{Ba} / \mathrm{Ca}$ records of individuals from Ligar Bay. Two abrupt, yet identical 3-point peaks were found in the $\mathrm{Ba} / \mathrm{Ca}$ ratio transects in the Ligar Bay 3B and 4B shells. Peaks in $\mathrm{Ba} / \mathrm{Ca}$ ratios were also observed in the Ligar Bay 1B and Ligar Estuary shells, as well as in several of the shells from other sites. These findings suggest $\mathrm{Ba} / \mathrm{Ca}$ peaks in $A$. stutchburyi are almost certainly linked to an environmental influence - possibly primary productivity or flooding, although more investigation of this effect is required.

4. Major inter-site differences in the range of $\mathrm{Mn} / \mathrm{Ca}$ and $\mathrm{U} / \mathrm{Ca}$ ratios exist between the Ligar Bay and remaining shells from other sites. These were interpreted as differences between the environment of a beach (Ligar Bay) and extensive mud flats (Miranda), which would have distinct sedimentary redox conditions, to which $\mathrm{U}$ and $\mathrm{Mn}$ are sensitive. This suggests that $A$. stutchburyi $\mathrm{Mn} / \mathrm{Ca}$ and $\mathrm{U} / \mathrm{Ca}$ ratios are in part an indicator of sediment redox conditions.

\subsection{Suggestions for future work}

This thesis study has identified several potential lines of further investigation including:

1. Directly comparing A. stutchburyi TE/Ca ratios with the environmental parameters that they could be related to. Such parameters would include SST, salinity, chlorophyll, rainfall (storm records), and seawater TE/Ca ratios. Real-time records from when the individuals were growing should ideally be used to allow for precise comparison. Growing the clams in culture where these parameters could be monitored while the clams grew would be one way to derive such information. 
2. The first suggestion requires a higher-resolution, more accurate chronology to be constructed for A. stutchburyi. This could be achieved by ${ }^{18} \mathrm{O}$ analysis, as discussed in Chapter 4, and, or by closer study and measurement of A. stutchburyi growth, by transplanting and collecting the clams, or growing them in culture.

3. Focussing on multiple individuals from a few sites (of different latitude and with different redox conditions to Ligar Bay). Individuals could grow differently in warmer or colder conditions - providing more or less continuous geochemical records. Further, individuals from the same site but from different positions in the intertidal zone should be studied to assess tidal effects, such as the length of submergence, on shell chemistry. 


\subsection{REFERENCES}

Appledoorn, R. S. (1983). "Variation in the growth rate of Mya arenaria and its relationship to the environment as analyzed through principal components analysis and the parameter of the von Bertalanffy equation." Fish. Bull. U.S. 81: 75-84

Arbuszewski, J., P. deMenocal, et al. (2010). "On the fidelity of shell-derived $\delta 180$ seawater estimates." Earth and Planetary Science Letters 300(3-4): 185-196.

Barnes, C. E. and J. K. Cochran (1993). "Uranium geochemistry in estuarine sediments: Controls on removal and release processes." Geochimica et Cosmochimica Acta 57(3): 555-569.

Beentjes, M. P. and B. G. Williams (1986). "Endogenous circatidal rhythmicity in the New Zealand cockle Chione stutchburyi (Bivalvia, Veneridae)." Marine Behaviour and Physiology 12(3): 171 - 180.

Beu, A. G. (2006). "Marine Mollusca of oxygen isotope stages of the last 2 million years in New Zealand. Part 2. Biostratigraphically useful and new Pliocene to recent bivalves." Journal of the Royal Society of New Zealand 36(4): 151 - 338.

Bishop, J. K. B. (1988). "The barite-opal-organic carbon association in oceanic particulate matter." Nature 332(6162): 341-343.

Bots, P. and T. Behrends (2008). "Uranium mobility in subsurface aqueous systems: the influence of redox conditions." Mineral Mag 72(1): 381-384.

Bowen, H. J. M. (1956). "Strontium and barium in sea water and marine organisms." Journal of the Marine Biological Association of the United Kingdom 35(03): 451-460.

Brockington, S. and A. Clarke (2001). "The relative influence of temperature and food on the metabolism of a marine invertebrate." Journal of Experimental Marine Biology and Ecology 258(1): 87-99.

Broecker, W.S. and T.H. Peng. (1982) Tracers in the Sea. Eldigio Press, Palisades, New York.

Carré, M., I. Bentaleb, et al. (2005). "Stable isotopes and sclerochronology of the bivalve Mesodesma donacium: Potential application to Peruvian paleoceanographic reconstructions." Palaeogeography Palaeoclimatology Palaeoecology 228(1-2): 4-25.

Carré, M., I. Bentaleb, et al. (2006). "Calcification rate influence on trace element concentrations in aragonitic bivalve shells: Evidences and mechanisms." Geochimica et Cosmochimica Acta 70(19): 4906-4920.

Carter, J.G. (1980). "Guide to bivalve microstructures," in: Rhoads, D.C. and R.A. Lutz (eds.), Skeletal growth of aquatic organisms: Biological records of environmental change. Plenum press, New York, 1:645-651. 
Chow, T. J. and E. D. Goldberg (1960). "On the marine geochemistry of barium." Geochimica et Cosmochimica Acta 20(3-4): 192-198.

Clark, G.R., (1979). "Seasonal growth variations in the shells of recent and prehistoric specimens of Mercenaria mercenaria from St. Catherines Island Georgia.:" Anthropol. Pap. Am. Mus. Nat. Hist. 56: 161-172

Cléroux, C., E. Cortijo, et al. (2008). "Mg/Ca and $\mathrm{Sr} / \mathrm{Ca}$ ratios in planktonic foraminifera: Proxies for upper water column temperature reconstruction." Paleoceanography 23(3): PA3214.

Coffey, M., F. Dehairs, et al. (1997). "The Behaviour of Dissolved Barium in Estuaries." Estuarine, Coastal and Shelf Science 45(1): 113-121.

Cohen, A. L. and T. A. McConnaughey (2003). Geochemical perspectives on coral mineralization. Biomineralization. P. M. Dove, J. J. DeYoreo and S. Weiner. Washington, Mineralogical Soc America. 54: 151-187.

Coutts, P. J. F. (1974). "Growth characteristics of the bivalve <i>Chione stutchburyi</i>." New Zealand Journal of Marine and Freshwater Research 8(2): $333-339$.

Crowley, t. J., d. A. Short, et al. (1986). "Role of Seasonality in the Evolution of Climate During the Last 100 Million Years." Science 231(4738): 579-584.

Dalton R, Menzel W (1983) "Seasonal gonadal development of young laboratoryspawned southern (Mercenaria campechiensis) and northern (Mercenaria mercenaria) quahoqs and their reciprocal hybrids in northern Florida." J Shellfish Res 3:11-17

Dehairs, F., R. Chesselet, et al. (1980). "Discrete suspended particles of barite and the barium cycle in the open ocean." Earth and Planetary Science Letters 49(2): 528550 .

Dehairs, F., C. Lambert, et al. (1987). "The biological production of marine suspended barite and the barium cycle in the Western Mediterranean Sea." Biogeochemistry 4(2): 119-140.

Deuser, W. G. and E. H. Ross (1989). "Seasonally abundant planktonic-foraminifera of the sargasso sea - succession, deep-water fluxes, isotopic compositions, and paleoceanographic implications." Journal of Foraminiferal Research 19(4): 268293.

Dietzel, M., N. Gussone, et al. (2004). "Co-precipitation of $\mathrm{Sr}^{2+}$ and $\mathrm{Ba}^{2+}$ with aragonite by membrane diffusion of $\mathrm{CO} 2$ between 10 and $50{ }^{\circ} \mathrm{C}$." Chemical Geology 203(1-2): 139-151. 
Dobbinson SJ, Barker MF, Jillett JB (1989) "Experimental shore level transplantation of the New Zealand cockle Chione stutchburyi." J. Shell Res 9:197-212

Dodd, J. R. (1964). "Environmentally Controlled Variation in the Shell Structure of a Pelecypod Species." Journal of Paleontology 38(6): 1065-1071.

Dodd, J. R. (1965). "Environmental control of strontium and magnesium in Mytilus." Geochimica et Cosmochimica Acta 29(5): 385-398.

Dodd, J. R. and E. L. Crisp (1982). "Non-linear variation with salinity of sr/ca and $\mathrm{mg} / \mathrm{ca}$ ratios in water and aragonitic bivalve shells and implications for paleosalinity studies." Palaeogeography Palaeoclimatology Palaeoecology 38(12): 45-56.

Elderfield, H. and G. Ganssen (2000). "Past temperature and $\delta 180$ of surface ocean waters inferred from foraminiferal Mg/Ca ratios." Nature 405(6785): 442-445.

Elderfield, H., R. Rickaby, et al. (2006). "How do marine carbonate $\mathrm{Mg} / \mathrm{Ca}$ and $\mathrm{Sr} / \mathrm{Ca}$ proxies constrain Cenozoic ocean history." Geochimica et Cosmochimica Acta 70(18): A158-A158.

Elliot, M., K. Welsh, et al. (2009). "Profiles of trace elements and stable isotopes derived from giant long-lived Tridacna gigas bivalves: Potential applications in paleoclimate studies." Palaeogeography, Palaeoclimatology, Palaeoecology 280(1-2): 132-142.

Emiliani, C. (1955). "Pleistocene temperatures." Journal of Geology 63(6): 538-578.

Epstein,S.,R. Buchsbaum, et al. (1953). "Revised carbonate-water isotopic temperature scale." Geological Society of America Bulletin 64(11): 1315-1326.

Erez, J. and S. Honjo (1981). "Comparison of isotopic composition of planktonicforaminifera in plankton tows, sediment traps and sediments." Palaeogeography Palaeoclimatology Palaeoecology 33(1-3): 129-156.

Evans, J. W. (1972). "Tidal growth increments in cockle clinocardium nuttalli." Science 176(4033): 416-420

Ford, H. L., S. A. Schellenberg, et al. (2010). "Evaluating the skeletal chemistry of Mytilus californianus as a temperature proxy: Effects of microenvironment and ontogeny." Paleoceanography 25(1): PA1203.

Foster, L. C., A. A. Finch, et al. (2008). "Mg in aragonitic bivalve shells: Seasonal variations and mode of incorporation in Arctica islandica." Chemical Geology 254(1-2): 113-119.

Fox, D. L. and W. R. Coe (1943). "Biology of the California sea-mussel (Mytilus californianus). II. Nutrition, metabolism, growth and calcium deposition." Journal of Experimental Zoology 93(2): 205-249. 
Freitas, P. S., L. J. Clarke, et al. (2006). "Environmental and biological controls on elemental $(\mathrm{Mg} / \mathrm{Ca}, \mathrm{Sr} / \mathrm{Ca}$ and $\mathrm{Mn} / \mathrm{Ca})$ ratios in shells of the king scallop Pecten maximus." Geochimica et Cosmochimica Acta 70(20): 5119-5133.

Gaetani, G. A. and A. L. Cohen (2006). "Element partitioning during precipitation of aragonite from seawater: A framework for understanding paleoproxies." Geochimica et Cosmochimica Acta 70(18): 4617-4634.

Gall and Zeldis (2003). "Oceanography in Tasman and Golden bays” Niwa

Gillikin, D., A. Lorrain, et al. (2008). "Synchronous barium peaks in high-resolution profiles of calcite and aragonite marine bivalve shells." Geo-Marine Letters 28(5): 351-358.

Gillikin, D. P., F. Dehairs, et al. (2006). "Barium uptake into the shells of the common mussel (Mytilus edulis) and the potential for estuarine paleo-chemistry reconstruction." Geochimica et Cosmochimica Acta 70(2): 395-407.

Gillikin, D. P., A. Lorrain, et al. (2005). "Strong biological controls on Sr/Ca ratios in aragonitic marine bivalve shells." Geochem. Geophys. Geosyst. 6(5): Q05009.

Goldberg, E. D. and G. O. S. Arrhenius (1958). "Chemistry of pacific pelagic sediments." Geochimica et Cosmochimica Acta 13(2-3): 153-212.

Goldsmith, J. R., D. L. Graf, et al. (1961). "Lattice constants of the calcium-magnesium carbonates." American Mineralogist 46(3-4): 453-457.

Goodwin, D. H., K. W. Flessa, et al. (2001). "Cross-Calibration of Daily Growth Increments, Stable Isotope Variation, and Temperature in the Gulf of California Bivalve Mollusk Chione cortezi: Implications for Paleoenvironmental Analysis." Palaios 16(4): 387-398.

Goodwin, D. H., B. R. Schone, et al. (2003). "Resolution and Fidelity of Oxygen Isotopes as Paleotemperature Proxies in Bivalve Mollusk Shells: Models and Observations." Palaios 18(2): 110-125.

Green, R.H., 1973. "Growth and mortality in an arctic intertidal population of Malcoma balthica (Pelecypoda, Tellinidae)." Journal of the Fisheries Research Board Canada 30: 1345-1348.

Grégoire, C. (1972). "Structure of the molluscan shell," in: Florkin, M. and B.T. Scheer (eds.), Chemical Zoology. Academic press, New York, vol. VII: Mollusca: 45102.

Heap, A. D. and S. L. Nichol (1997). "The influence of limited accommodation space on the stratigraphy of an incised-valley succession: Weiti River estuary, New Zealand." Marine Geology 144(1-3): 229-252. 
Higham, T. F. G., and A. G. Hogg. (1997) "Evidence for late Polynesian colonisation of New Zealand: University of Waikato radiocarbon measurements." Radiocarbon 39(2): 149-192.

Hollis, C. J., L. Handley, et al. (2009). "Tropical sea temperatures in the high-latitude South Pacific during the Eocene." Geology 37(2): 99-102.

Horiguchi, Y., M. Miyake, et al. (1954). "Biochemical studies with radioactive isotopes on Pteria (Pinctada) martensii (Dunkers) and Hyriopsis schlegelii (v. Martens). I. Ca metabolism by $\mathrm{Ca}^{45}$ tracer in Hyriopsis schlegelii (v. Martens).” Bull. Jap. Soc. scient. Fish. 20: 101-106.

Jones, C. C. (1979). "Anatomy of Chione cancellata and some other chionines (bivalvia, veneridae)." Malacologia 19(1): 157-199.

Jones, D. S. (1980). "Annual Cycle of Shell Growth Increment Formation in Two Continental Shelf Bivalves and its Paleoecologic Significance." Paleobiology 6(3): 331-340.

Jones, M.B. (1983). “Animals of the estuary shore: and illustrated guide.” University of Canterbury, Christchurch: 162.

Jodrey, L.H. (1953). "Studies on shell formation. III. Measurement of calcium deposition in shell and calcium turnover in mantle tissue using the mantle-shell preparation and $\mathrm{Ca}^{45}$." Biol. Bull. 104: 394-397.

Kanazawa, T. and S. i. Sato (2008). "Environmental and physiological controls on shell microgrowth pattern of Ruditapes philippinarum (Bivalvia: Veneridae) from Japan." Journal of Molluscan Studies 74(1): 89-95.

Katz, M. E., B. S. Cramer, et al. (2010). "Traditional and emerging geochemical proxies in foraminifera." Journal of Foraminiferal Research 40(2): 165-192.

Kennedy, D. M. (2008). "Recent and future higher sea levels in New Zealand: A review." New Zealand Geographer 64(2): 105-116.

Kinsman, D. J. J. and H. D. Holland (1969). "co-precipitation of cations with $\mathrm{CaCO}_{3} .4$. Co-precipitation of $\mathrm{Sr}^{2+}$ with aragonite between 16 degrees and 96 degrees c." Geochimica et Cosmochimica Acta 33(1): 1-\&.

Klein, R. T., K. C. Lohmann, et al. (1996). "Bivalve skeletons record sea-surface temperature and $\delta 18 \mathrm{O}$ via $\mathrm{Mg} / \mathrm{Ca}$ and $18 \mathrm{O} / 16 \mathrm{O}$ ratios." Geology 24(5): 415-418.

Klein, R. T., K. C. Lohmann, et al. (1996). "Sr/Ca and 13C/12C ratios in skeletal calcite of Mytilus trossulus: Covariation with metabolic rate, salinity, and carbon isotopic composition of seawater." Geochimica et Cosmochimica Acta 60(21): 4207-4221.

Klinkhammer, G. P., A. C. Mix, et al. (2009). "Increased dissolved terrestrial input to the coastal ocean during the last deglaciation." Geochem. Geophys. Geosyst. 10(3): Q03009. 
Kobayashi, I. and T. Samata (2006). "Bivalve shell structure and organic matrix." Materials Science \& Engineering C-Biomimetic and Supramolecular Systems 26(4): 692-698.

Larcombe, M.L. (1971). "The ecology, population dynamics and energetic of some soft shore mollusks." PhD thesis, University of Auckland.

Lazareth, C. E., E. V. Putten, et al. (2003). "High-resolution trace element profiles in shells of the mangrove bivalve Isognomon ephippium: a record of environmental spatio-temporal variations?" Estuarine, Coastal and Shelf Science 57(5-6): 1103-1114.

Lea, D. W. (2003). Elemental and Isotopic Proxies of Past Ocean Temperatures. Treatise on Geochemistry. D. H. Heinrich and K. T. Karl. Oxford, Pergamon: 126.

Lea, D. W., D. K. Pak, et al. (2000). "Climate impact of late quaternary equatorial Pacific sea surface temperature variations." Science 289(5485): 1719-1724.

Lear, C. H., H. Elderfield, et al. (2000). "Cenozoic deep-sea temperatures and global ice volumes from $\mathrm{Mg} / \mathrm{Ca}$ in benthic foraminiferal calcite." Science 287(5451): 269272.

Livingston, H. D. and G. Thompson (1971). "Trace Element Concentrations in Some Modern Corals." Limnology and Oceanography 16(5): 786-796.

Lorens, R. B. (1981). "Sr, Cd, Mn and Co distribution coefficients in calcite as a function of calcite precipitation rate." Geochimica et Cosmochimica Acta 45(4): 553-561.

Lorens, R. B. and M. L. Bender (1980). "The impact of solution chemistry on Mytilus edulis calcite and aragonite." Geochimica et Cosmochimica Acta 44(9): 12651278.

Lorrain, A., D. P. Gillikin, et al. (2005). "Strong kinetic effects on Sr/Ca ratios in the calcitic bivalve Pecten maximus." Geology 33(12): 965-968.

McCulloch, M., S. Fallon, et al. (2003). "Coral record of increased sediment flux to the inner Great Barrier Reef since European settlement." Nature 421(6924): 727-730.

McKinnon, J.F. (1996). "Studies of the age, growth and shell increment patterns in the New Zealand Cockle (Austrovenus stutchburyi)." MSc thesis, University of Otago.

Miao, S., R. D. DeLaune, et al. (2006). "Influence of sediment redox conditions on release/solubility of metals and nutrients in a Louisiana Mississippi River deltaic plain freshwater lake." Science of The Total Environment 371(1-3): 334-343. 
Ministry of Fisheries, "Cockles (Coc)" < http://fs.fish.govt.nz/ > Accessed 2010

Miyaji, T., K. Tanabe, et al. (2007). "Environmental controls on daily shell growth of Phacosoma japonicum (Bivalvia: Veneridae) from Japan." Marine Ecology Progress Series 336: 141-150.

Morford, J. L., A. D. Russell, et al. (2001). "Trace metal evidence for changes in the redox environment associated with the transition from terrigenous clay to diatomaceous sediment, Saanich Inlet, BC." Marine Geology 174(1-4): 355-369.

Morris, A. W. (1971). "Trace Metal Variations in Sea Water of the Menai Straits caused by a Bloom of Phaeocystis." Nature 233(5319): 427-428.

Morse, J. W. and M. L. Bender (1990). "Partition coefficients in calcite: Examination of factors influencing the validity of experimental results and their application to natural systems." Chemical Geology 82(C): 265-277.

Morse, J. W. and A. Mucci (1984). "Composition of carbonate overgrowths produced on Iceland spar calcite crystals buried in bahamian carbonate-rich sediments." Sedimentary Geology 40(4): 287-291.

Mortyn, P. G. and C. D. Charles (2003). "Planktonic foraminiferal depth habitat and \& 180 calibrations: Plankton tow results from the Atlantic sector of the Southern Ocean." Paleoceanography 18(2): 1037.

Mucci, A. (1987). "Influence of temperature on the composition of magnesian calcite overgrowths precipitated from seawater." Geochimica et Cosmochimica Acta 51(7): 1977-1984.

Mucci, A. and J. W. Morse (1983). "The incorporation of $\mathrm{Mg}^{2+}$ and $\mathrm{Sr}^{2+}$ into calcite overgrowths: influences of growth rate and solution composition." Geochimica et Cosmochimica Acta 47(2): 217-233.

Muir, R. J., S. D. Weaver, et al. (1995). "The Cretaceous Separation Point batholith, New Zealand: granitoid magmas formed by melting of mafic lithosphere." Journal of the Geological Society 152(4): 689-701.

Palmer, J. D. (1995). "Review of the dual-clock control of tidal rhythms and the hypothesis that the same clock governs both circatidal and circadian rhythms." Chronobiology International 12(5): 299-310.

Panella, G. (1975). "Paleontological clocks and the history of the Earth's rotation". In: Growth Rhythms and the History of the Earth's Rotation, (eds. G.D. Rosenberg and S.K. Runcorn), Wiley, London: 253-284.

Paytan, A., K. Averyt, et al. (2007). "Barite accumulation, ocean productivity, and $\mathrm{Sr} / \mathrm{Ba}$ in barite across the Paleocene-Eocene Thermal Maximum." Geology 35(12): 1139-1142.

Powell, A.W.B. (1979). New Zealand Mollusca. Marine, land and freshwater shells. Auckland, Collins: 500. 
Purchase, N. G. and J. E. Fergusson (1986). "Chione (austrovenus) stutchburyi, a New Zealand cockle, as a Bio-indicator for lead pollution." Environmental Pollution Series B, Chemical and Physical 11(2): 137-151.

Purton, L. M. A., G. A. Shields, et al. (1999). "Metabolism controls $\mathrm{Sr} / \mathrm{Ca}$ ratios in fossil aragonitic mollusks." Geology 27(12): 1083-1086.

Putten, E. V., F. Dehairs, et al. (2000). "High resolution distribution of trace elements in the calcite shell layer of modern mytilus edulis: environmental and biological controls." Geochimica et Cosmochimica Acta 64(6): 997-1011.

Richardson, C. A. (2001). Molluscs as archives of environmental change. Oceanography and Marine Biology, Vol 39. London, Taylor \& Francis Ltd. 39: 103-164.

Richardson, C. A., D. J. Crisp, et al. (1980). "Factors Influencing Shell Growth in Cerastoderma edule." Proceedings of the Royal Society of London. Series B, Biological Sciences 210(1181): 513-531.

Richardson, C. A., R. Seed, et al. (1990). "Use of internal growth bands for measuring individual and population-growth rates in mytilus-edulis from offshore production platforms." Marine Ecology-Progress Series 66(3): 259-265.

Rosenberg, G. D. and W. W. Hughes (1991). "A metabolic model for the determination of shell composition in the bivalve mollusc, Mytilus edulis." Lethaia 24(1): 8396.

Sadekov, A., S. M. Eggins, et al. (2009). "Surface and subsurface seawater temperature reconstruction using $\mathrm{Mg} / \mathrm{Ca}$ microanalysis of planktonic Foraminifera Globigerinoides ruber, Globigerinoides sacculifer, and Pulleniatina obliquiloculata." Paleoceanography 24(3):3201-3201.

Savenko, V. S. (2008). "Concentrating function of plankton and the residence time of dissolved species of chemical elements in the ocean." Geochemistry International 46(2): 190-192.

Schmidt, M. W., H. J. Spero, et al. (2004). "Links between salinity variation in the Caribbean and North Atlantic thermohaline circulation." Nature 428(6979): 160163.

Schöne, B. (2008). "The curse of physiology — challenges and opportunities in the interpretation of geochemical data from mollusk shells." Geo-Marine Letters 28(5): 269-285.

Schöne, B. and J. Fiebig (2009). "Seasonality in the North Sea during the Allerød and Late Medieval Climate Optimum using bivalve sclerochronology." International Journal of Earth Sciences 98(1): 83-98.

Schöne, B., D. Rodland, et al. (2007). "Combined sclerochronologic and oxygen isotope analysis of gastropod shells (Gibbula cineraria; North Sea): life-history traits 
and utility as a high-resolution environmental archive for kelp forests." Marine Biology 150(6): 1237-1252.

Schone, B. R., E. Dunca, et al. (2005). "Mutvei's solution: An ideal agent for resolving microgrowth structures of biogenic carbonates." Palaeogeography Palaeoclimatology Palaeoecology 228(1-2): 149-166.

Schöne, B. R., A. D. Freyre Castro, et al. (2004). "Sea surface water temperatures over the period 1884-1983 reconstructed from oxygen isotope ratios of a bivalve mollusk shell (Arctica islandica, southern North Sea)." Palaeogeography, Palaeoclimatology, Palaeoecology 212(3-4): 215-232.

Schöne, B. R., S. D. Houk, et al. (2005). "Daily growth rates in shells of Arctica islandica: Assessing sub-seasonal environmental controls on a long-lived bivalve mollusk." Palaios 20(1): 78-92.

Schöne, B. R., Z. Zhang, et al. (2011). "Sr/Ca and Mg/Ca ratios of ontogenetically old, long-lived bivalve shells (Arctica islandica) and their function as paleotemperature proxies." Palaeogeography, Palaeoclimatology, Palaeoecology 302(1-2): 52-64.

Sinclair, D. J. and M. T. McCulloch (2004). "Corals record low mobile barium concentrations in the Burdekin River during the 1974 flood: Evidence for limited Ba supply to rivers?" Palaeogeography, Palaeoclimatology, Palaeoecology 214(1-2): 155-174.

Skinner, H. C. W. and A. H. Jahren (2007). Biomineralization. Treatise on Geochemistry. D. H. Heinrich and K. T. Karl. Oxford, Pergamon: 1-69.

Stecher, H. A., D. E. Krantz, et al. (1996). "Profiles of strontium and barium in Mercenaria mercenaria and Spisula solidissima shells." Geochimica et Cosmochimica Acta 60(18): 3445-3456.

Sunda, W. G. and S. A. Huntsman (1985). "Regulation of Cellular Manganese and Manganese Transport Rates in the Unicellular Alga Chlamydomonas." Limnology and Oceanography 30(1): 71-80.

Takesue, R. K., C. R. Bacon, et al. (2008). "Influences of organic matter and calcification rate on trace elements in aragonitic estuarine bivalve shells." Geochimica et Cosmochimica Acta 72(22): 5431-5445.

Takesue, R. K. and A. van Geen (2004). "Mg/Ca, Sr/Ca, and stable isotopes in modern and Holocene Protothaca staminea shells from a northern California coastal upwelling region." Geochimica et Cosmochimica Acta 68(19): 3845-3861.

Tesoriero, A. J. and J. F. Pankow (1996). "Solid solution partitioning of $\mathrm{Sr}^{2+,} \mathrm{Ba}^{2+,}$ and $\mathrm{Cd}^{2+}$ to calcite." Geochimica et Cosmochimica Acta 60(6): 1053-1063.

Torres, M. E., J. P. Barry, et al. (2001). "Reconstructing the History of Fluid Flow at Cold Seep Sites from Ba/Ca Ratios in Vesicomyid Clam Shells." Limnology and Oceanography 46(7): 1701-1708. 
Urey, H. C. (1947). "The thermodynamic properties of isotopic substances." Journal of the Chemical Society May: 562-581.

Van Der Borght, O. and S. Van Puymbroeck (1966). "Calcium metabolism in a freshwater mollusc : Quantitative importance of water and food as supply for calcium during growth." Nature 210(5038): 791-793.

Vander Putten, E., F. Dehairs, et al. (2000). "High resolution distribution of trace elements in the calcite shell layer of modern Mytilus edulis: Environmental and biological controls." Geochimica et Cosmochimica Acta 64(6): 997-1011.

Watabe, N., and R.J Kingsley. (1989). "Extra-, inter-, and intracellular mineralization in invertebrates and algae." In Origin, Evolution, and Modern Aspects of Biomineralization in Plants and Animals. (ed. R.E. Crick) Plenum, New York: 209-223

Wheeler A. P. (1992). "Mechanisms of molluscan shell formation." In Calcification in Biological systems (ed. E. Bonucci). CRC Press: 179-216.

Wood, W. (1828). "A supplement to the Index Testaceologicus, or a catalogue of shells, British and foreign." London

Wilbur, K.M., and A.S.M. Saleuddin. (1983). The Mollusca: vol 5 Physiology (ed. Wilbur K.M.) Academic Press, New York: 237-286. 